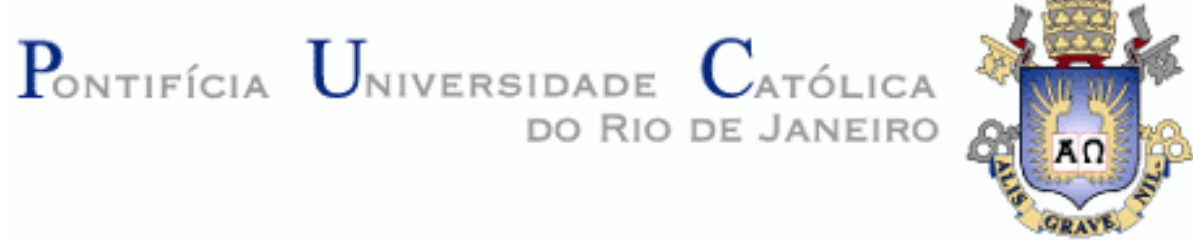

Sérgio Hamilton da Silva Barra

\title{
llustração e Memória: A Impressão Régia do Rio de Janeiro e o projeto do novo Império português
}

Tese apresentada ao Programa de Pós-Graduação em História Social da Cultura do Departamento de História da PUC-Rio como parte dos requisitos parciais para obtenção do título de Doutor em História.

Orientador: Prof. IImar Rohloff de Mattos 


\title{
Sergio Hamilton da Silva Barra
}

\begin{abstract}
Ilustração e Memória: A Impressão Régia do Rio de Janeiro e o projeto do novo Império português

Tese apresentada como requisito parcial para obtenção do grau de Doutor pelo Programa de Pós-Graduação em História Social da Cultura do Departamento de História do Centro de Ciências Sociais da PUC-Rio.

Aprovada pela Comissão Examinadora abaixo assinada.
\end{abstract}

\section{Prof. IImar Rohloff de Mattos}

Orientador

Departamento de História - PUC-Rio

Profa Ivana Stolze Lima

Departamento de História - PUC-Rio

Profa Lúcia Maria Bastos Pereira das Neves

Departamento de História - UERJ

Profa Márcia de Almeida Gonçalves

Departamento de História - UERJ

Prof ${ }^{\mathrm{a}}$ Ana Rosa Cloclet da Silva Departamento de História - PUC-CAMPINAS

Profa. Mônica Herz

Vice-Decana de Pós-Graduação do Centro de Ciências Sociais

PUC-Rio

Rio de Janeiro, 30 de agosto de 2012 
Todos os direitos reservados. É proibida a reprodução total ou parcial do trabalho sem autorização da universidade, do autor e do orientador.

\section{Sérgio Hamilton da Silva Barra}

Graduou-se em História na Universidade do Estado do Rio de Janeiro (UERJ), em 2003 e concluiu o mestrado em História Social da Cultura na PUC-Rio, em 2006. Possui especialização em patrimônio cultural pelo IPHAN e pela UNESCO (Programa de Especialização em Patrimônio - PEP, turma de 2006). Atuou como tutor à distância no curso de Licenciatura em História do Departamento de História da PUCRio.

Ficha Catalográfica

Barra, Sérgio Hamilton da Silva

Ilustração e memória : a impressão régia do Rio de Janeiro e o projeto do novo império português / Sérgio Hamilton da Silva Barra ; orientador: Ilmar Rohloff de Mattos. - 2012.

236 f. ; $30 \mathrm{~cm}$

Tese (doutorado)-Pontifícia Universidade Católica do Rio de Janeiro, Departamento de História, 2012.

Inclui bibliografia

1. História - Teses. 2. História social da cultura. 3. Impressão régia. 4. Império português. 5. Império do Brasil. 6. Memória. 7. Ilustração. 8. D. Rodrigo de Sousa Coutinho (1755-1812). 9. D. João VI (1767-1826). 10. José da Silva Lisboa (1756-1835). I. Mattos, IImar Rohloff de. II. Pontifícia Universidade Católica do Rio de Janeiro. Departamento de História. III. Título. 


\section{Agradecimentos}

Ao atingir o término de mais essa jornada cumpre agradecer àqueles que me ajudaram a enfrentá-la e superá-la. Pois, como já escrevi em outro lugar, por mais solitário que seja o ato de escrever uma tese, as companhias certas podem oferecer o apoio necessário, sem o qual se tornaria muito mais difícil vencer esse desafio.

Em primeiro lugar, mais do que uma obrigação formal, é um grande prazer poder agradecer, mais uma vez, ao professor Ilmar Rohloff de Mattos. Não apenas pela sempre atenciosa e generosa leitura e orientação, mas também pelos estimulantes debates que tivemos a ocasião de travar durante as reuniões que marcaram os últimos quatro anos. Debates que, por vezes, extrapolavam o tema desse trabalho e recaíam sobre temas diversos, que poderiam ir desde os prazeres e as agruras do ofício de historiador até as amenidades da vida cotidiana. Nossas reuniões de trabalho, das quais com certeza sentirei falta, ajudaram a tornar mais leve o processo, por vezes angustiante, de escrita da tese. Me considero um privilegiado por ter a oportunidade de compartilhar da sua companhia durante os últimos oito anos.

Gostaria de agradecer também às professoras Margarida de Souza Neves e Maria Elisa Mäder, que foram coordenadoras do Programa de Pós-Graduação em História Social da Cultura da PUC-Rio durante o período em que cursei o meu doutorado, e de quem sempre recebi todo o apoio possível, principalmente durante os momentos difíceis que passei logo no início dessa jornada. E ao professor Luís Reznik, coordenador do curso de licenciatura em História à Distância da PUCRio, que sempre demonstrou muita confiança no meu trabalho como professor, me concedendo a oportunidade de atuar tanto como professor do departamento de História, em aulas presenciais na própria PUC no ano de 2009, quanto como tutor à distância durante todo o período de atividade do curso de Licenciatura à Distância.

Um agradecimento mais do que especial deve ser dedicado à Berenice Chiavegatto Campos, com quem mais intensamente dividi os momentos bons e ruins dessa jornada desde antes do seu início de fato. Com a sensibilidade que lhe 
é característica, e que tanto me atrai, soube intuir os momentos certos de se aproximar mais para dar o apoio que eu necessitava; assim como os momentos em que era melhor distanciar-se um pouco, tanto para permitir que eu obtivesse o silêncio necessário à reflexão, quanto para preservar-se dos efeitos dos eventuais acessos de ansiedade. Merece, sobretudo, um agradecimento por suportar bem a obrigação de me ouvir falar, ao longo dos últimos quatro anos, sobre assuntos que lhe são completamente estranhos, sem demonstrar nunca irritação ou tédio.

Companhias muito menos frequentes mas, por vezes, mais antigas são aqueles amigos que acompanham o meu percurso acadêmico desde a graduação, com quem tenho o prazer e o privilégio de desfrutar uma fértil interlocução intelectual. Gostaria de agradecer, especialmente, a dois deles que se souberam fazer sempre presentes ao longo dos últimos anos, apesar da distância física: Marcelo Rangel e Amanda Danelli. Amigos preocupados e interlocutores interessados, com quem sempre pude não apenas discutir as idas e vindas da elaboração da tese, mas também os assuntos extra-acadêmicos que orbitam esse processo e que, por vezes, entram em rota de colisão com ele. Qualquer pausa para um cafezinho com vocês é garantia de bons momentos.

Por último, mas não menos importante, cumpre fazer os agradecimentos aos apoios institucionais: ao Departamento de História da PUC-Rio, na pessoa de Edna Maria Lima Timbó, secretária do Programa de Pós-Graduação em História Social da Cultura; aos funcionários do Real Gabinete Português de Leitura e da Seção de Obras Raras da Biblioteca Nacional, onde fiz a quase totalidade das minhas pesquisas; Pontifícia Universidade Católica do Rio de Janeiro e ao Conselho Nacional de Desenvolvimento Científico e Tecnológico (CNPq) pelas bolsas concedidas. 


\section{Resumo}

Barra, Sérgio Hamilton da Silva; Mattos, Ilmar Rohloff de. Ilustração e memória: a Impressão Régia do Rio de Janeiro e o projeto do novo império português. Rio de Janeiro, 2012. 236 p. Tese de Doutorado Departamento de História, Pontifícia Universidade Católica do Rio de Janeiro.

O presente trabalho se propõe compreender o papel político exercido pela Impressão Régia do Rio de Janeiro por meio da sua atuação no contexto da instalação da Corte portuguesa na América, buscando chamar a atenção para a relação intrínseca entre cultura e poder nos projetos imperiais portugueses. Abordada como agente histórico, a Impressão Régia se apresenta como a face cultural do projeto político de criação de um novo império português na América, longamente acalentado por letrados e estadistas ilustrados portugueses e posto em prática com a transferência da Corte para o Rio de Janeiro. Frente às tensões políticas que a nova situação criada pela mudança da sede do Império gerava, a Impressão Régia desempenhou o importante papel de legitimação e sustentação desse projeto político, pelo menos até o fim efetivo da censura prévia da imprensa no Reino do Brasil em 28 de agosto de 1821. Por meio da continuação do trabalho de difusão das Luzes no Império português, e da construção da metamemória do reinado de D. João na América, a Impressão Régia do Rio de Janeiro busca estabelecer uma relação de continuidade entre o passado, o presente e o futuro da monarquia portuguesa, passando por cima dos momentos de ruptura apenas vivenciados.

\section{Palavras-Chave}

Impressão Régia; Império Português; Império do Brasil; Memória; Ilustração; D. Rodrigo de Sousa Coutinho (1755-1812); D. João VI (1767-1826); José da Silva Lisboa (1756-1835). 


\section{Abstract}

Barra, Sérgio Hamilton da Silva; Mattos, Ilmar Rohloff de. Enlightenment and memory: the Impressão Régia do Rio de Janeiro and the project of the new portuguese empire. Rio de Janeiro, 2012. 236 p. Doctoral Thesis Departamento de Historia, Pontifícia Universidade Católica do Rio de Janeiro.

This study aims to realize the political role exercised by the Impressão Régia do Rio de Janeiro through its performance in the context of the installation of the Portuguese Court in America, seeking to highlight to the intrinsic relationship between culture and power on the Portuguese imperial projects. Adressed as an historical agent, the Impressão Régia presents itself as the cultural aspect of the political project of a new Portuguese empire creation in America, a long cherished by illustrated Portuguese scholars and statemen and implemented by the Court transfer to Rio de Janeiro. In the face of the political tensions that was generated by the new situation created by the Empire seat moving, the Impressão Régia has played an important role in legitimizing and sustaining of this political project, at least until the effective end of previous censorship in Kingdon of Brazil press on August 28, 1821. Through the continuation of work of dissemination of the Lights in the Portuguese empire, and the building of the reign metamemory of D. João in America, the Impressão Régia do Rio de Janeiro aims to stablish a continuity relationship between past, present and future of the Portuguese monarchy, passing over the rupture moments just experienced.

\section{Keywords}

Impressão Régia, Portuguese Empire, Brazilian Empire, Memory, Enlightenment, D. Rodrigo de Sousa Coutinho (1755-1812), D. João VI (17671826), José da Silva Lisboa (1756-1835). 


\section{Sumário}

1. Introdução 9

2. A Impressão Régia e a llustração Portuguesa 29

2.1. Lusitanas Luzes 34

2.2. Sem Impressão não há llustração 58

3. O Império sob as Luzes da Economia Política 89

3.1. E agora, Josés? 89

3.2. O Império do Livre-Comércio 105

3.3. As manufaturas entre a liberação e os privilégios 127

4. A Memória de um Poderoso Império 148

4.1. A Transferência e suas re-presentificações 154

4.2. "Proteção à Francesa" 183

5. Considerações Finais 208

6. Referências Bibliográficas 223

6.1. Fontes 223

6.1.1. Livros 223

6.1.2. Periódicos 226

6.2. Livros e artigos 227 


\title{
Introdução
}

\author{
"O poder de narrar, ou de impedir que se \\ formem e surjam outras narrativas, é \\ muito importante para a cultura e o \\ imperialismo, e constitui uma das \\ principais conexões entre ambos". (SAID, \\ E. Cultura e Imperialismo, p. 13)
}

Em Cultura e Imperialismo, publicado em 1993, Edward Said investiga como a literatura de ficção produzida na Inglaterra e na França ao longo do século XIX e primeira metade do XX, ao mesmo tempo reflete e alimenta a atitude imperialista que guiou essas potências à colonização de regiões distantes, possuídas e habitadas por outros povos. O objetivo do seu livro é o de explicitar a relação existente entre aquelas obras literárias e a prática imperial inglesa e francesa de que faziam parte. Ao representar nos seus livros cenários e personagens pertencentes ao mundo colonial, romancistas ingleses e franceses assumiam o papel da literatura como partícipe daquele processo, criando estruturas de sentimento que o sustentavam, elaboravam e consolidavam. $\mathrm{O}$ autor chama a atenção para o fato de que os autores desses romances, expoentes do cânone da literatura mundial, estavam imersos naquelas relações imperiais e eram, ao mesmo tempo, constituintes delas; refutando a ideia de que a cultura, de uma forma geral e a literatura, em particular, estariam divorciadas do mundo cotidiano e, portanto, da política (entendida em sentido amplo, como relações de poder). A estética estaria, segundo ele, atravessada por uma conjuntura que é anterior ao autor e que o influencia na elaboração de sua obra, ao mesmo tempo em que sua obra também influencia a conjuntura em que ela se insere.

Não creio que os escritores sejam mecanicamente determinados pela ideologia, pela classe ou pela história econômica, mas acho que estão profundamente ligados à história de suas sociedades, moldando e moldados por essa história e suas experiências sociais em diferentes graus. A cultura e suas formas estéticas derivam da experiência histórica. ${ }^{1}$

Por outro lado, ressalta o autor que a cultura também se tornou o método usado pelos povos colonizados para afirmar sua identidade e a existência de uma história própria para eles. A partir do processo de descolonização, essas

\footnotetext{
${ }^{1}$ SAID, E. Cultura e Imperialismo, p. 23. No Brasil, a primeira edição da obra de Said é de 1999.
} 
populações passaram a pedir ouvidos para as suas narrativas. Dessa forma, colonizadores e colonizados coexistiram e combateram um ao outro por meio de representações, narrativas e histórias rivais.

Rui Tavares, no seu artigo Lembrar, esquecer, censurar, se apropria da ideia de Said para analisar as articulações entre o poder, a censura e a memória no Império Português durante a fase final do regime do marquês de Pombal (17501777). O autor chama a atenção para a censura enquanto tentativa de controlar o que deve ser lembrado e o que deve ser esquecido, assim como a forma como deve ser lembrado e a forma como deve ser esquecido. Assim, a censura seria, ela também, uma forma de construção da memória. ${ }^{2}$ Ressalta o autor que a intervenção sobre a memória é crucial para a prática do poder. A censura e a propaganda desempenhariam, no território da memória, o equivalente às funções que desempenham as fortalezas, os baluartes e os exércitos no território geográfico dos reinos e dos impérios. ${ }^{3}$ Modificando as palavras cultura e imperialismo por memória e censura, Tavares adapta a argumentação de Said ao seu objeto: "o poder de narrar, ou de bloquear a formação e emergência de outras narrativas, é muito importante tanto para a memória como para a censura e constitui uma das principais ligações entre ambas". ${ }^{4}$ Dessa forma, a construção e proibição de narrativas é também o objeto da análise de Tavares: "Qualquer poder busca a sua legitimação nas narrativas. Qualquer poder, regime ou instituição se funda, literalmente, com uma narrativa e se justifica através da narrativa também". 5

O presente trabalho se insere na esteira das reflexões de Said e Tavares, uma vez que ele também é, em última análise, um trabalho sobre o poder de narrar e, ao mesmo tempo, de impedir a formação e surgimento de narrativas. Mais especificamente, é um trabalho sobre a relação entre cultura e poder na atuação do órgão da administração do Império Português responsável por aquelas funções durante o período de estabelecimento da Corte portuguesa no Rio de Janeiro: a Impressão Régia do Rio de Janeiro, criada por decreto do Príncipe Regente de 13

\footnotetext{
2 “A censura (bem como a propaganda) é uma forma de intervir sobre as memórias do passado e reconfigurar as narrativas através das quais ela sobrevive”. TAVARES, R. Lembrar, Esquecer, Censurar, p. 144.

${ }^{3}$ Ibid., p. $142 / 143$.

${ }_{5}^{4}$ Ibid., p. 144.

${ }^{5}$ Ibid., p. 144/145.
} 
de maio de $1808 .{ }^{6}$ Como ressalta Rubens Borba de Moraes, caberia ao novo órgão a impressão de toda a legislação e papéis diplomáticos que emanassem de qualquer repartição do Real Serviço. E, como não havia outra tipografia na colônia, ao menos oficialmente, cabia-lhe também imprimir todas as outras obras. Porém, apenas depois de cumprida a tarefa de publicar os atos do governo, necessária e essencial ao bom andamento da burocracia. ${ }^{7}$

Entre folhetos, opúsculos, sermões, oratória sacra, odes, prospectos, peças de teatro, obras literárias e científicas versando sobre agricultura, comércio, ciências naturais, matemática, história, economia política, direito, medicina, filosofia, romance, poesia e educação, além de traduções de textos franceses e ingleses, foram publicados mais de mil itens até $1822{ }^{8}$ Além das coleções de atos oficiais e de livros, a Impressão Régia publicou também o primeiro periódico da colônia: a Gazeta do Rio de Janeiro, que circulou ininterruptamente de 10 de setembro de 1808 até o final do reinado de D. João no Rio de Janeiro, e era responsável pela divulgação dos atos do monarca, do calendário ritual da Corte e de notícias de cunho político tiradas de periódicos europeus, sobretudo ingleses e franceses. A tipografia publicou ainda, entre 1813 e 1814, a revista O Patriota: Jornal literário, político e mercantil, cujo redator Manuel Ferreira de Araújo Guimarães (1777-1838) era ao mesmo tempo redator da Gazeta do Rio de Janeiro. Periódico de cultura e ciências que publicava estudos de literatura, história, geografia, estatística, política, filosofia entre outros, $O$ Patriota teve entre seus colaboradores importantes nomes da Ilustração luso-brasileira como: José Bonifácio de Andrada e Silva (1763-1838), Silvestre Pinheiro Ferreira (17691846) e Mariano José Pereira da Fonseca (1773-1848), entre outros. Segundo

\footnotetext{
${ }^{6} \mathrm{O}$ nome de batismo, Impressão Régia, foi sendo alterado ao longo do reinado de D. João: em 1815, passou a Régia Oficina Tipográfica; em 1818, mudou o nome para Tipografia Real; e a partir de 1822 passa a chamar-se Typographia Nacional. Para evitar possíveis confusões causadas pela troca de nome, utilizarei ao longo desse trabalho somente a denominação de Impressão Régia, pela qual a tipografia é mais conhecida.

7 MORAES, R. B. de. Livros e Bibliotecas no Brasil Colonial, p. 100/101. Citando Pereira da Silva, em sua História da fundação do Império Brasileiro, Laurence Hallewell matiza essa interpretação de Borba de Moraes aludindo a existência de um prelo no Brasil, por ocasião da chegada da corte, que seria usado pelo vice-rei para impressos oficiais. HALLEWELL, L. O livro no Brasil, p. 34.

${ }^{8}$ Hallewell fala em 1173 títulos, distribuídos da seguinte maneira: 38 em 1808, 62 em 1809, 99 em 1810, 71 em 1811, 62 em 1812, 30 em 1813, 24 em 1814, 44 em 1815, 49 em 1816, 46 em 1817, 41 em 1818, 44 em 1819, 42 em 1820, 243 em 1821 e 296 em 1822. Sendo grande parte dessa produção constituída daquilo que ele denominou de publicações secundárias: documentos do governo, cartazes, volantes, sermões, panfletos entre outros. HALLEWELL, op. cit., p. 37.
} 
definição de Lorelai Kury, "O Patriota foi o primeiro jornal brasileiro a publicar artigos densos e analíticos sobre ciências e artes, cultura e letras". 9

A esse balanço da produção da Impressão Régia pode-se somar ainda a grande produção de estampas e gravuras que incluía retratos de personalidades, mapas (dos quais o exemplo mais conhecido é certamente a Planta da Cidade de S. Sebastião do Rio de Janeiro levantada por Ordem de Sua Alteza Real o Príncipe Regente Nosso Senhor no ano de 1808. Feliz e memorável época da sua chegada à dita cidade, terminada apenas em 1812), e, principalmente, imagens didáticas que compunham as obras de matemática, arte militar ou História Natural, publicadas pela tipografia. Um rico acervo iconográfico, em suma, mas que não será abordado nesse trabalho. ${ }^{10}$ A Impressão Régia detinha ainda, desde 1811, o privilégio da fabricação das Cartas de Jogar o que lhe aliviava o orçamento dando-lhe renda garantida. A fabricação de baralhos era monopólio da Coroa, havendo fábricas na Bahia e no Rio de Janeiro. ${ }^{11}$

A criação da Impressão Régia não passou despercebida aos principais memorialistas do reinado de D. João, que fizeram questão de registrar o fato nas suas memórias, ressaltando a sua importância. O Padre Luiz Gonçalves dos Santos, nas suas Memórias para servir à história do Reino do Brasil, onde tem a intenção de fazer a crônica daqueles que ele considera os principais atos administrativos de D. João durante a sua permanência na América portuguesa, se refere da seguinte forma ao decreto de criação da tipografia:

O Brasil até ao feliz dia 13 de maio de 1808 não conhecia o que era tipografia, foi necessário que a brilhante face do Príncipe Regente Nosso Senhor, bem como o refulgente sol, viesse vivificar este país, não só quanto à sua agricultura, comércio, e indústria, mas também quanto às artes, e ciências, dissipando as trevas da ignorância, cujas negras e medonhas nuvens cobriam todo o Brasil, e interceptavam as luzes da sabedoria. Assim, por decreto datado deste mesmo dia dos seus felizes anos, Sua Alteza Real foi servido mandar que se estabelecesse

\footnotetext{
${ }^{9}$ KURY, L. (org.). Iluminismo e Império no Brasil - O Patriota (1813-1814), p. 9.

${ }^{10}$ Explica Alfredo do Valle Cabral que os primeiros gravadores que chegaram ao Rio de Janeiro em 1808, Romão Eloy Cazado Almeida (ou Almeida Cazado) e Paulo dos Santos Ferreira Souto, vinham acompanhando Frei José Mariano da Conceição Velloso (1742-1811), botânico natural de Minas Gerais, provavelmente para abrirem as chapas da sua Flora Fluminensis, e entraram no ano seguinte para a Impressão Régia. Como ressalta o autor: "A história da introdução da gravura em cobre e em madeira no Brasil está, como a da imprensa, intimamente ligada à da Typographia Nacional. Ao ilustre fr. Velloso devemos pois mais este relevante serviço, porque se não fora ele não teríamos de certo artistas insignes como F. Souto e R. E. Almeida para introduzirem a arte de gravar no país" (CABRAL, A. do V. Annaes da Imprensa Nacional do Rio de Janeiro de 1808 a 1822, p. L).

${ }^{11}$ MORAES, op. cit., p. 104.
} 
nesta Corte a Impressão Régia. ${ }^{12}$

Porém, a conturbada conjuntura política que determinou a transferência da Corte para o Rio de Janeiro impunha a necessidade da existência de um órgão que se responsabilizasse não apenas pela disseminação das luzes da sabedoria na nova Corte, tal como escreve Gonçalves dos Santos; mas também, ou principalmente, que assumisse a tarefa de, pela divulgação dos acontecimentos a partir de uma ótica favorável a Portugal, justificasse e legitimasse as decisões tomadas pelo Príncipe Regente. A Impressão Régia do Rio de Janeiro exercia, dessa forma, o importante papel político de dar sustentação à monarquia ao construir a memória dos principais fatos que marcaram os 13 anos de reinado de D. João no Rio de Janeiro, ressaltando a relação existente entre cultura e poder no Império português.

A memória é uma representação seletiva do passado, feita a partir do momento presente, e cujo atributo mais imediato é servir de instância construtora e cimentadora de identidades. Motivo pelo qual a sua expressão coletiva também atua como instrumento e objeto de poder, mediante a seleção do que se recorda e do que, consciente ou inconscientemente, se silencia. Fernando Catroga utiliza o conceito de metamemória para definir essa memória coletiva ou histórica ativamente produzida e reproduzida por esse trabalho de seleção. ${ }^{13}$ Segundo o sociólogo austríaco Michael Pollack, a memória coletiva seria construída por aquilo que ele denomina de um trabalho de enquadramento da memória, realizado por atores sociais diretamente ligados às instituições construtoras dessa memória, e que visa evitar a disputa entre diferentes memórias pela hegemonia da forma como datas e acontecimentos serão gravados na memória de um povo. ${ }^{14} \mathrm{E}$ sob esse viés do trabalho de enquadramento da memória e da construção da metamemória do reinado de D. João que se procura analisar aqui a atuação da Impressão Régia do Rio de Janeiro dentro da estrutura administrativa do Império Português.

Para essa tarefa contribuíam as publicações de diferentes naturezas emanadas dos prelos da Impressão Régia, portassem elas o título de memórias ou

\footnotetext{
${ }^{12}$ SANTOS, L. G. dos. Memórias para servir à história do Reino do Brasil, tomo 1, p. 207.

${ }^{13}$ CATROGA, F. Os passos do homem como restolho do tempo: memória e o fim da história, p. 15.

${ }^{14}$ POLLACK, M. Memória, esquecimento, silêncio, p. 7 a 11.
} 
não. A esse respeito é necessário atentar para o fato de que, no início do século XIX o termo memórias não se referia apenas a obras que tratassem da representação de fatos políticos passados, sendo utilizado também para trabalhos científicos de qualquer natureza. É dessa forma que é possível encontrar entre as publicações da Impressão Régia, por um lado, exemplares daquilo que denominamos aqui de memorialismo científico, obras que tratam de História Natural ou Economia Política, tais como a Memória sobre as salitreiras naturais de Monte Rorigo, de autoria de José Vieira Couto (1809), a Memória econômica sobre a raça do gado lanígero da capitania do Ceará, de João da Silva Feijó (1811) ou Memória econômica sobre a franqueza do commercio dos vinhos do Porto, de José da Silva Lisboa (1812); e, por outro lado, exemplares de memorialismo histórico, tais como a Memória histórica da invasão dos franceses em Portugal no ano de 1807, do Bispo José Caetano da Silva Coutinho (1808) ou a Memória dos Benefícios Políticos do governo de el-rey Nosso Senhor D. João VI, mais uma vez de autoria de José da Silva Lisboa (1818). Memorialismo científico e memorialismo histórico ou político contribuíam para a construção da memória de D. João como um monarca protetor e patrocinador das artes e das ciências, tal como consolidada na obra do Padre Gonçalves dos Santos.

Porém, como ficou dito acima, a Impressão Régia tinha não apenas o poder de narrar, mas também o de impedir a formação de narrativas, sendo a censura outra forma de construção da memória. Gonçalves dos Santos esquece propositalmente do fato de que as luzes da sabedoria não brilhavam até então na colônia portuguesa da América por culpa da própria monarquia de Bragança, que proibiu a instalação de tipografias na colônia pela Ordem Régia de D. João V, datada de 6 de julho de 1747, que mandou fechar a tipografia de Antonio Isidoro da Fonseca, impressor lisboeta que havia se instalado no Rio de Janeiro. A ordem determinava o sequestro e envio para o Reino de prelo, tipos, papel, estoque de livros e até do próprio impressor, levantando justificativas econômicas e burocráticas:

Dom João por graça de Deus, rei de Portugal e dos Algarves, d'aquém e d'além mar, em África Senhor da Guiné etc. Faço saber a vós, governador e capitão general da Capitania do Rio de Janeiro, que por constar que deste reino tem ido para o Estado do Brasil quantidade de letras de imprensa, no qual não é conveniente se imprimam papéis no tempo presente, nem ser de utilidade aos 
impressores trabalharem no seu ofício aonde as despesas são maiores que no Reino, do qual podem ir impressos os livros e papéis, ao mesmo tempo em que dele devem ir as licenças da Inquisição e do meu Conselho Ultramarino, sem as quais se não podem imprimir, nem correm as obras. ${ }^{15}$

Porém, a alegada preocupação da Coroa com o possível prejuízo econômico a que se arriscavam os tipógrafos que pretendessem se instalar na colônia, nada mais era do que a forma encontrada para encobrir a sua verdadeira preocupação, com o controle da circulação de ideias na colônia. Que transparece na última parte do documento, que se refere às licenças necessárias para a impressão e circulação das obras. ${ }^{16}$ Em Junho de 1808 foi nomeada uma Junta Administrativa para a Impressão Régia, que servia também como Junta Diretora da Gazeta do Rio de Janeiro, e tinha entre as suas atribuições o exame de tudo o que se mandasse publicar e o impedimento da impressão de papéis e livros cujo conteúdo contrariasse o governo, a religião e os bons costumes. ${ }^{17}$ A Junta era composta de três diretores: José Bernardo de Castro, oficial da Secretaria de Estado dos Negócios Estrangeiros e da Guerra, Mariano José Pereira da Fonseca e José da Silva Lisboa, deputados das Mesas de Inspeção da Agricultura e Comércio do Rio de Janeiro e da Bahia respectivamente. A partir de 1815 passou a contar com mais um membro: Silvestre Pinheiro Ferreira, Deputado da Real Junta do Comércio.

Por meio do decreto de 27 de setembro de 1808, o Príncipe Regente atendeu à solicitação da Mesa do Desembargo do Paço que reivindicava o seu direito de exercer a jurisdição sobre a censura de livros, com base no alvará de 17 de dezembro de $1794 .{ }^{18}$ Para exercer tal função fiscalizadora foram escolhidos como censores régios: Frei Antonio de Arrábida, Padre José de Carvalho e Melo e o

\footnotetext{
15 Apud. MORAES, op. cit., p. 64.

${ }^{16}$ Borba de Moraes chama a atenção para o caráter mercantilista do documento, afirmando que ele revela a preocupação da Coroa com a concorrência que as tipografias estabelecidas na colônia poderiam fazer às tipografias do Reino (MORAES, op. cit., p. 65).

17 Aviso de 24 de junho de 1808. Como explica Borba de Moraes, as obras autorizadas a circular deveriam ostentar a sua licença: "Quando uma obra era mandada publicar pelo governo trazia ao pé da página de rosto a indicação: Por Ordem de $S$. A. R. Já as publicações feitas por conta do autor traziam no mesmo lugar a menção: Com Licença de S. A. R. ou simplesmente: Com Licença" (MORAES, op. cit., p. 109).

${ }^{18}$ O alvará de 17 de dezembro de 1794 extinguiu a Comissão Geral para o Exame e a Censura dos Livros criada por decreto de D. Maria I de 21 de junho de 1787, reestabelecendo a censura tripartida exercida pelo Ordinário, pela Inquisição, e pelo Desembargo do Paço. Determinava as diferentes esferas de atuação de cada um desses três órgãos. A partir de então a Igreja podia fazer o exame dos livros religiosos, mas era o Estado que avaliava os livros sobre assuntos laicos e que podia baixar a proibição ou não de todos os livros, fossem eles religiosos ou não. Dessa forma, o Desembargo do Paço desempenhava um papel central (e final) no processo censório, deixando claro que a sua preocupação principal passava do plano religioso para o plano político.
} 
mesmo José da Silva Lisboa que já atuava na Junta Administrativa. Por esse arranjo, a Junta Administrativa ficaria responsável pela censura preventiva, proibindo a impressão de obras consideradas ofensivas à religião e ao Estado; enquanto o Desembargo do Paço atuaria majoritariamente na censura repressiva, exercendo o controle da circulação pela fiscalização da sua entrada nos portos e alfândega e a visita a livrarias. ${ }^{19}$ Completava o aparelho repressivo do Estado português no Rio de Janeiro a Intendência Geral de Polícia da Corte e Estado do Brasil que, logo após a sua criação por Decreto de 13 de maio de 1808, mandou divulgar um aviso em que se proibia afixarem anúncios de livreiros em lugares públicos sem que antes fossem entregues à Intendência para exame e censura. ${ }^{20}$

Como complemento desse trabalho, a censura tinha também o papel de introduzir as modernas luzes do século nas monarquias que se pretendiam ilustradas, selecionando textos da República das Letras para publicação, evitando a disseminação das ideias políticas francesas, mas incentivando os livros que pregavam reformas prudentes e esclarecidas. Dessa forma, não parece fazer sentido a ideia de que a censura se constituía, nessa conjuntura, um entrave ao desenvolvimento científico no Império Português. A censura no Império Português nunca foi totalmente impermeável à circulação de ideias, como mostram Lúcia Bastos e Tania Bessone no artigo O medo dos abomináveis princípios franceses: a censura dos livros nos inícios do século XIX no Brasil. Analisando a atuação da censura na tentativa de conter os avanços das ideias revolucionárias francesas no Império português, as autoras concluem que:

A despeito da incessante intervenção dos censores, zelosos em seus pareceres para preservar os bons costumes, a religião e a estabilidade do governo, os "abomináveis princípios franceses" infiltravam-se entre a intelectualidade lusobrasileira. $^{21}$

Esse aparato censório vigorou durante praticamente todo o período de

${ }^{19}$ Como informa Tereza Cristina Kirschner, entre 1814 e 1818 foram nomeados novos censores por causa do aumento significativo de livros que chegavam do exterior. Cinco em 1814: frei Innocêncio Antonio das Neves, padre D. Antonio de Nossa Senhora da Graça, padre Manuel do Loreto Bastos, Dr. Manuel Luiz Álvares de Carvalho e frei Antonio de Santa Úrsula Rodovalho. Em 1818, foram nomeados, ainda frei José Doutel, o tenente general do Exército Real, Francisco de Borja Garção Stockler e Mariano José Pereira da Fonseca, membro da Junta Diretora da Impressão Régia desde 1808 e deputado da Real Junta do Comércio. KIRSCHNER, T. C. José da Silva Lisboa, Visconde de Cairu: Itinerários de um ilustrado luso-brasileiro, p. 155.

${ }^{20}$ ALGRANTI, L. M. A censura no tempo de D. João VI, p. 139.

${ }^{21}$ NEVES, L. M. P. \& FERREIRA, T. M. T. B. da C. O medo dos abomináveis princípios franceses: a censura dos livros nos inícios do século XIX no Brasil, p. 114. 
governo de D. João no Rio de Janeiro. Até que em 2 de março de 1821, D. João foi obrigado a assinar, por pressão da Junta de Governo da Revolução do Porto, um decreto que abolia a censura prévia para a imprensa em geral. Pelo menos aparentemente, porque por esse decreto a censura não se faria mais sobre os manuscritos, mas sobre as provas tipográficas. ${ }^{22}$ Após a regulamentação da liberdade de imprensa nos debates constitucionais nas Cortes de Lisboa e o aviso do Príncipe Regente D. Pedro de 28 de agosto de 1821, que estabelecia a efetiva abolição da censura prévia no Brasil, embora com restrições, multiplicaram-se as tipografias particulares. Como explica Borba de Moraes:

Todas essas primeiras oficinas particulares fundadas com mais entusiasmo do que capital, para defender os novos ideais constitucionais e a Independência, produziram uma quantidade de gazetas efêmeras, hinos patrióticos, proclamações, discursos, cartas e folhetos políticos. Esses impressos mostram os anseios de um povo que passava bruscamente de um regime absolutista e colonial à autonomia e à liberdade de imprensa. Graças a essas tipografias atacava-se, defendia-se, caluniava-se à vontade. ${ }^{23}$

A partir desse momento não se pode mais aludir ao papel político da Impressão Régia na sustentação da monarquia absoluta pela construção da sua metamemória, uma vez que, não estando mais submetida à censura oficial a tipografia mesma muda de caráter, participando intensamente do debate sobre a monarquia constitucional. Além disso, a pluralidade de vozes abafaria a sua eficácia no desempenho desse papel. O que, para os objetivos desse trabalho, justifica o seu recorte cronológico entre o decreto de criação da Impressão Régia,

${ }^{22}$ Para Nelson Werneck Sodré, o decreto não alterava em muito a situação da imprensa: "continuavam proibidos os escritos contra a religião, a moral, os bons costumes, a Constituição, a pessoa do rei, a tranqüilidade pública - contra qualquer coisa, contra tudo, em suma" (SODRÉ, N. W. História da Imprensa no Brasil, p. 47). Também segundo Lúcia Bastos não houve mudança efetiva, "pois os impressores não correriam o risco de proceder à impressão de um trabalho, sob a ameaça de perdê-lo posteriormente, em função das correções exigidas ou de sua proibição" (NEVES, L. M. B. P. Um silêncio perverso: censura, repressão e o esboço de uma primeira esfera pública de poder, p. 136).

${ }^{23}$ MORAES, op cit., p. 106. Segundo enumeração feita por Nelson Werneck Sodré e Rubens Borba de Moraes, em 1821 surgiram mais duas tipografias no Rio de Janeiro: a Nova Tipografia (ou Nova Oficina Tipográfica) e a tipografia de Moreira e Garcez. No ano seguinte, surgem mais quatro: a de Silva Porto e Cia., de Felizardo Joaquim da Silva Morais e Manuel Joaquim da Silva Porto, oriundo da Impressão Régia e livreiro; a de Vitorino José dos Santos e Sousa, que fundou a tipografia Anaes Fluminenses para publicar a revista homônima que, porém, não passou do primeiro número, mas continuou a imprimir folhetos políticos; a Tipografia do Diário, de Zeferino Vitor de Meireles, também oriundo da Impressão Régia, que imprimia o Diário do Rio de Janeiro e toda sorte de impressos; e a Torres e Costa, de Inocêncio Francisco Torres e Vicente Justiniano da Costa, que publicava efêmeros papéis políticos (MORAES, op. cit., p. 106 e SODRÉ, op. cit., p.42). Laurence Hallewell refere-se ainda à modesta Typographia Astréia, que imprimia jornal do mesmo nome (HALLEWELL, op. cit.,p. 45). 
13 de maio de 1808 , e o decreto de 28 de agosto de 1821.

Os autores que primeiro se ocuparam da história da imprensa no Brasil sempre ressaltaram o papel da Impressão Régia do Rio de Janeiro como a introdutora da imprensa nessa parte da América, ao mesmo tempo em que minimizavam esse mesmo papel, chamando a atenção para o seu caráter de imprensa oficial ou áulica. ${ }^{24}$ É o que se pode observar dos trabalhos hoje clássicos de Carlos Rizzini, O livro, o jornal e a tipografia no Brasil, 1500-1822, de 1945, Nélson Werneck Sodré, História da Imprensa no Brasil, de 1966, e de Rubens Borba de Moraes, Livros e bibliotecas no Brasil Colonial, de 1979. Ao se referirem, por exemplo, à Gazeta do Rio de Janeiro, sobressai, na análise desses três autores, o caráter oficial daquele periódico, por ser de propriedade de uma Secretaria de Estado e estar submetido à rígida censura por parte do governo. O que diminuiria o seu interesse como fonte e comprometeria o seu papel como documento histórico. ${ }^{25}$ Rizzini caracteriza as suas matérias como "enfadonhos róis de atos oficiais, convenientes apanhados de folhas européias e intermináveis ditirambos à família reinante", ${ }^{26}$ Borba de Moraes o considera "um verdadeiro diário oficial"; ${ }^{27}$ enquanto Nelson Werneck Sodré o caracterizou, mais cruelmente, como um "pobre papel impresso" ou "arremedo de jornal”: "Jornal oficial, feito na imprensa oficial, nada nele constituía atrativo para o público, nem essa era a preocupação dos que o faziam, como a dos que o haviam criado". ${ }^{28}$

Invertendo essa perspectiva, estudos mais recentes, como o de Lilia Moritz Schwarcz, apontam que o interesse histórico da atuação da Impressão Régia advém justamente do seu caráter oficial, que faz com que ela desempenhe um importante papel na nova arquitetura política que se montava no Rio de Janeiro, uma vez que era o órgão responsável pela divulgação dos atos oficiais, decisões e

\footnotetext{
${ }^{24}$ Importante ressaltar que a revisão historiográfica que ora se empreende não pretende dar conta da tarefa hercúlea que seria comentar toda a bibliografia publicada sobre o reinado de D. João no Rio de Janeiro ou mesmo sobre a atuação da imprensa naquele período. Tem antes, a intenção de apontar duas diferentes perspectivas acerca daquela atuação, com o fim de demarcar o lugar que esse trabalho tem a pretensão de ocupar entre os estudos que tratam do tema.

${ }^{25}$ Sem querer reduzir a produção da Impressão Régia à publicação da Gazeta do Rio de Janeiro, é importante ressaltar que grande parte da historiografia da imprensa no Brasil concentra-se na análise dos periódicos, em detrimento dos livros. Por esse motivo, os estudos que abordam o primeiro periódico publicado na colônia sobressaem entre a historiografia que se ocupou da Impressão Régia e, consequentemente, também nesse balanço historiográfico.

${ }^{26}$ RIZZINI, C. O livro, o jornal e a tipografia no Brasil, 1500-1822: um breve estudo geral sobre a informação, p. 332.

${ }^{27}$ MORAES, op. cit., p. 121.

${ }^{28}$ SODRÉ, op. cit., p. 23.
} 
ordens do governo, assim como pela publicação ou censura de toda e qualquer obra, "sobretudo aquelas que ajudassem a divulgar a imagem da própria monarquia". ${ }^{29}$ Na mesma direção vai a reflexão de Juliana Gesuelli Meirelles, que na sua obra sobre a Gazeta do Rio de Janeiro, publicada em 2008, chamou a atenção para papel de relevo desempenhado pelo periódico na sustentação do reinado de d. João no Rio de Janeiro. A Coroa Portuguesa sob o governo joanino concebeu a imprensa como parte fundamental da sua ação política e cultural e, consequentemente, em um âmbito mais amplo, "como âncora de sustentação do Império Português em ambos os lados do Atlântico". ${ }^{30}$ Como explica a autora:

Diferentemente das exaltações sociais, os protestos e resistências populares eram silenciados pela folha. A Gazeta do Rio de Janeiro jamais noticiava a indiferença e as ausências dos súditos nas festividades, ou mesmo as quebras de luminárias como a ocorrida em Portugal durante as comemorações da Aclamação de D. João VI, em 1818. Os fatos que ameaçavam a estabilidade do Império Português e/ ou não retratassem a imagem idílica que a monarquia desejava veicular não eram divulgados pela Gazeta do Rio de Janeiro e compuseram, ao longo do tempo, uma omissão fundamental no leque informativo do periódico. ${ }^{31}$

Em trabalho de 2003, Mariana Monteiro de Barros e Marco Morel identificavam uma renovação das abordagens políticas e culturais da imprensa segundo a qual esta deixa de ser vista como portadora dos "fatos" e da "verdade", por um lado, ou como um reflexo de ideias subordinadas a uma infra-estrutura socioeconômica, por outro; e é valorizada como fonte documental (na medida em que enuncia discursos e expressões de protagonistas sociais) e como agente histórico que intervém nos processos e episódios, em vez de servir-lhes como simples "reflexo". 32

É sob essa mesma perspectiva renovada, em que a imprensa é encarada não apenas como importante fonte documental, mas também como agente histórico, que a atuação da Impressão Régia do Rio de Janeiro é abordada no presente trabalho. Por essa perspectiva, que permite chamar a atenção para a indissolúvel relação entre cultura e poder que embasa o trabalho das tipografias nas

\footnotetext{
${ }^{29}$ SCHWARCZ, L. M. A Longa Viagem da Biblioteca dos Reis: do terremoto de Lisboa à Independência do Brasil, p. 249.

${ }^{30}$ MEIRELLES, J. G. Imprensa e poder na corte joanina: A Gazeta do Rio de Janeiro (18081821), p. 141.

${ }^{31}$ Ibid., p. 93.

${ }^{32}$ BARROS, M. M. de \& MOREL, M. Palavra, Imagem e Poder: O surgimento da Imprensa no Brasil do século XIX, p. 8/9.
} 
monarquias absolutas, procura-se ressaltar aqui, como já afirmado, o papel político fundamental desempenhado pela Impressão Régia do Rio de Janeiro como face cultural de um projeto político posto em prática durante o período de reinado de D. João no Rio de Janeiro: o projeto de criação de um novo império português a partir da sua colônia da América. Criação que deve ser entendida, porém, como re-criação do mesmo império português uma vez que, como ressalta Ilmar Rohloff de Mattos, a concepção de Império que havia muito acompanhava D. João o fazia desejar que a alma do velho reino passasse a animar o corpo do novo império que pretendia criar nos trópicos. ${ }^{33}$ Como chamou a atenção esse autor, esse novo império português continuava embasado pela mesma concepção clássica de Império, que embasava o antigo império português: uma concepção dinástica, caracterizada por agrupar territórios não necessariamente contíguos no espaço, transcendendo os quadros étnicos ou políticos naturais, e com pretensão a um domínio ilimitado espacial, temporal e ideologicamente. ${ }^{34}$ Mas, ao mesmo tempo, esse novo império era necessariamente outro, pois construído em uma situação nova, gerada pela própria transferência da Corte para a América. Na esteira das reflexões de Ilmar de Mattos, podemos afirmar que a construção desse novo império português não seria feita a partir do nada e sim sobre uma herança, ela também construída. ${ }^{35} \mathrm{E}$ a herança que definia os marcos dessa construção era o patrimônio intelectual do reformismo ilustrado português.

Maria de Lourdes Viana Lyra, questionando-se sobre as particularidades do processo de formação do Estado imperial no Brasil em A Utopia do Poderoso Império, publicado em 1994, chama a atenção para as continuidades existentes entre a ideia oriunda das reflexões do reformismo ilustrado português desde fins

\footnotetext{
${ }^{33}$ MATTOS, I. R. de. Verbete Rio de Janeiro. In: NEVES, L. M. P. \& VAINFAS, R. Dicionário do Brasil Joanino - 1808-1821. p. 393.

${ }^{34}$ MATTOS, I. R. de. Construtores e Herdeiros, p. 14.

${ }^{35}$ Ao analisar a trama dos interesses envolvidos na construção da unidade política do Império do Brasil, recém separado da sua metrópole, o autor chama a atenção para o papel desempenhado, nessa construção, por um conjunto de expectativas, valores e imagens que ele caracteriza como uma dupla herança. Aqueles que eram os construtores de um novo corpo político eram também, ao mesmo tempo, herdeiros de um território, que se pretendia manter unificado, e de um nome, o Império do Brasil, que de parte de um todo, o Império Português, passava a se constituir em um todo independente: "O antigo nome, que permanecia para designar o novo corpo político, tinha o poder de emocionar a muitos, suscitando orgulho e esperança. Não deixava de insinuar, porém, uma certa continuidade, em relação à ordem anterior, até mesmo porque no centro dos acontecimentos daqueles anos, tidos como decisivos, encontrava-se muitas vezes o próprio herdeiro do trono português". MATTOS, I. R. de. Construtores e Herdeiros: a trama dos interesses na construção da unidade política, p. 23.
} 
do século XVIII, da formação de um poderoso império que conciliasse os dois lados do Atlântico português como solução para a regeneração da monarquia portuguesa, e a proposta de construção do Império do Brasil. ${ }^{36}$ Concedendo especial atenção à atuação de D. Rodrigo de Sousa Coutinho como Secretário de Estado dos Negócios da Marinha e Estados Ultramarinos na consolidação desse projeto reformista ilustrado, a autora chama a atenção para a atuação conjunta de letrados do Reino e do Ultramar como parte de um mesmo movimento pautado em um projeto único e com vistas a um mesmo objetivo: "o reforço dos laços de unidade entre Portugal e o Ultramar, com o Brasil em especial, com vistas ao desenvolvimento integrado de um novo império, unificador da grande nação portuguesa." 37

A reflexão de Ana Rosa Cloclet da Silva também aborda o lugar dos letrados e estadistas luso-brasileiros no processo de construção da nação, buscando desvendar novas dimensões da relação entre continuidades e rupturas existentes nos projetos de re-erguimento do Império português e de emancipação da sua principal colônia. Ana Rosa ressalta a participação daquela geração de estadistas, formados na tradição do reformismo ilustrado português, no processo instável e não linear de transição da Colônia à nação independente, de modo a desvendar

tanto a filiação de ideias e projetos que identificou aqueles homens de experiências intelectuais e políticas relativamente comuns, quanto as reformulações sofridas por suas concepções acerca do papel assumido pelo Brasil, no conjunto do Império. ${ }^{38}$

Buscando analisar o processo na sua longa duração, a autora acompanha a difusão das Luzes em Portugal desde o seu início, em meados do século XVIII, ressaltando como foi no processo mesmo de responder às questões colocadas pela

\footnotetext{
${ }^{36}$ Segundo a autora, essas continuidades explicariam a adoção do ideal de Império, que distingue a formação do Estado brasileiro da dos outros países da América do Sul que conquistavam a sua independência na mesma época: "A Independência política do Brasil apresenta particularidades para as quais dedicamos atenção especial: ocorreu num movimento de aproximação e não de rejeição à antiga metrópole; manteve a unidade política de todo o território que compunha a América portuguesa; se constituiu em Império adotando a forma de governo monárquica, forma essa estranha ao Novo Mundo. Tais singularidades são entendidas pela historiografia como uma consequiência 'natural' do fato inusitado da transferência da sede do governo do império colonial português para o Brasil, no início do século XIX”. LYRA, M. de L. V. A Utopia do Poderoso Império - Portugal e Brasil: Bastidores da Política 1798-1822, p. 19.

${ }^{37}$ Ibid., p. 44.

${ }^{38}$ SILVA, A. R. C. da. Inventando a Nação: intelectuais ilustrados e estadistas luso-brasileiros na crise do Antigo Regime Português (1750-1822), p. 23. A autora concede especial atenção ao pensamento e atuação de José Bonifácio de Andrada e Silva nesse processo.
} 
incorporação das ideias ilustradas ao Estado absolutista que se começou a repensar o Império em sua totalidade, dando origem à dinâmica que atrelava os destinos do Reino à preservação dos vastos domínios ultramarinos. Ana Rosa chama especial atenção para o ano de 1808 como momento de inflexão dos projetos imperiais. A partir de então, a autora identifica o surgimento de perspectivas transatlânticas assimétricas que, progressivamente, se separam até chegarem a se antagonizar no contexto de instalação da monarquia constitucional, a partir de 1820:

Ao fim e ao cabo, o que assistimos a partir de 1808 é o engendramento de interesses e perspectivas diferenciadas entre os homens que atuaram na política luso-brasileira pelos dois lados do Atlântico, o que implicou na progressiva insustentabilidade do Regime absolutista e da unidade imperial. ${ }^{39}$

No seu livro Corcundas e Constitucionais: a cultura política da independência (que, apesar de publicado apenas em 2003, é fruto da sua tese de doutoramento defendida na USP em 1992), Lúcia Maria Bastos Pereira das Neves, a partir da leitura do que ela denomina de literatura de circunstância (panfletos políticos, folhetos e folhas avulsas), publicada em Portugal e no Brasil no contexto da Revolução de 1820, e das discussões suscitadas por essas publicações, também chama a atenção para a Ilustração portuguesa como matriz de uma cultura política que permanece no interior do Império português até o contexto da independência. ${ }^{40} \mathrm{~A}$ autora chama a atenção para o fato de que foi no ambiente das Luzes portuguesas que se formaram e se iniciaram na vida pública as "elites política e intelectual luso-brasileiras" (nas palavras da autora) responsáveis pelos acontecimentos do período de 1820 a 1823:

Embora os indivíduos componentes dessa elite fossem solidários entre si, para manter a regra do jogo político, não se pode afirmar que constituíssem um grupo monolítico. Apresentavam, entretanto, uma homogeneidade cultural obtida graças à formação no ambiente da Ilustração portuguesa e, muitas vezes, coroada pela passagem através da Universidade de Coimbra. ${ }^{41}$

No artigo Da Repulsa ao Triunfo - ideias francesas no Império Luso-

\footnotetext{
${ }^{39}$ Ibid., p. 232.

${ }^{40}$ Segundo definição da autora, cultura política deve ser entendida como uma construção histórica que se adapta e se transforma em sintonia tanto com os acontecimentos quanto com as atitudes dos indivíduos e dos grupos, cujos objetivos, por sua vez, ela define. NEVES, L. M. B. P das. Corcundas e Constitucionais: a cultura política da independência, p. 25.

${ }^{41}$ Ibid., p. 49
} 
Brasileiro, 1808-1815, Lúcia Bastos analisou a trajetória da aceitação das ideias, gostos e costumes franceses como símbolos de uma sociabilidade civilizada no Rio de Janeiro, a partir da instalação da Corte portuguesa e da consequente e necessária formação de uma sociedade de corte ao seu redor, que propiciaram uma transformação no ambiente cultural da colônia. Ressaltando o papel fundamental que a imprensa assumiu nesse processo e, pó consequencia, na re-construção da monarquia portuguesa a partir da América.Tendo o ano de 1815 como ponto de clivagem, pode-se identificar um primeiro momento de repulsa às ideias, gostos e costumes oriundos da França, marcado pela conjuntura do conflito europeu e das invasões francesas em Portugal, onde a Impressão Régia se constituiu, ao lado da Intendência de Polícia, em um dos meios de conter a propaganda e a infiltração das perigosas ideias francesas; e um segundo momento, marcado pela conjuntura de reaproximação diplomática entre os dois países que se abre com a queda de Napoleão e a restauração da Casa de Bourbon no trono da França, em que ela se apresenta como difusora de ideias, gostos e costumes vindos diretamente da França, que passam a ser não somente aceitos, mas desejados na sede do Império português, como símbolos de Civilização:

Em conseqüência, a influência francesa passou pouco a pouco a ter um papel significativo nas relações culturais. Nos avisos da Gazeta do Rio de Janeiro aumentaram vertiginosamente as ofertas de produtos de luxo franceses, tais como quadros, papel pintado, canquilherias, porcelanas, cristais, vidros, anunciados por Dumont, ourives francês; panos de linho, cambraias, plumas; vestidos das últimas modas, oferecidos por Carlos Durand; vinhos em barrica e em garrafas de Bordeaux, licores engarrafados, vinhos de Champagne; e mesmo pão fabricado 'com trigo lavado à moda de França'. ${ }^{42}$

O apoio das Luzes ao trono, expressão utilizada por José da Silva Lisboa para se referir à "política de promoção das ciências e das artes" praticada por d. João, era mais do que benvindo nessa conjuntura delicada da história da monarquia portuguesa, que colocava o Príncipe-Regente na posição de ver como única salvação para a sua Coroa o abandono da metrópole e a instalação em território colonial. ${ }^{43}$ Mas, no momento em que tal projeto, longamente acalentado

\footnotetext{
${ }^{42}$ NEVES, L. M. B. P. das. Da Repulsa ao Triunfo-ideias francesas no Império Luso-Brasileiro, 1808-1815, p. 47. Artigo publicado no Dossiê D. João VI, do número 31 dos Anais do Museu Histórico Nacional, de 1999.

43 “A sinopse de sua [de D. João] legislação prova que ele não estimava a teima por virtude nem a ignorância por base da sociedade. Antes, ao contrário, que está persuadido que as luzes não só constituem o esplendor, mas também o apoio do Trono. A experiência tem mostrado que os povos
} 
pela Ilustração portuguesa, foi finalmente posto em prática ele sofreu necessárias modificações, devendo adaptar-se à nova situação, criada pela própria instalação da corte na colônia. Frente a todos os problemas de legitimidade que essa situação gerava, a Impressão Régia do Rio de Janeiro desempenhou o importante papel político de sustentação da monarquia, pelo menos até o fim efetivo da censura prévia da imprensa no Reino do Brasil pelo aviso do Príncipe Regente D. Pedro de 28 de agosto de 1821. Ocupou um lugar importante dentro da estrutura administrativa do Império, apresentando-se como a face cultural daquele projeto político ao exercer a sua função de propaganda e censura. Componentes da sua posição de construtora da metamemória do reinado de D. João, em um momento de afirmação de identidades sociais e de poderes políticos na monarquia portuguesa. $^{44}$

Alguns daqueles letrados e estadistas formados na reformada Universidade de Coimbra, correspondentes da Academia Real das Ciências de Lisboa e participantes ativos nas discussões travadas no ambiente intelectual ilustrado português, foram também os principais responsáveis por essa tentativa de construção do novo império português na América. Esses homens preservaram o patrimônio intelectual do reformismo ilustrado português, construindo-o como herança a ser apropriada naquele processo, pelas instituições culturais que faziam parte da estrutura administrativa do Império português instalada no Rio de Janeiro, tais como o Museu Real, a Real Biblioteca, o Horto Botânico, a Academia Real Militar e, a que nos interessa no caso específico desse trabalho, a Impressão Régia. A presença em postos-chave da nova tipografia, daqueles homens que já haviam trabalhado e publicado nas tipografias então criadas para a

rudes são mais difíceis de se regerem, e mais sujeitos a serem iludidos por cabalas de ambiciosos e turbulentos, e que quanto maior é a confiança no Governo, e melhor se conhecem os direitos e deveres de todos, tanto é mais pronta a obediência, mais constante a subordinação e mais respeitadas as autoridades, pela evidência do comum interesse na manutenção da Ordem Civil e Constituição do Estado". LISBOA, J. da S. Memória dos benefícios políticos do governo d'el Rei D. João VI, p. 21.

${ }^{44}$ Em direção semelhante parece se mover a reflexão de Diogo Ramada Curto, em Cultura Imperial e projetos coloniais (séculos XV a XVIII), onde o autor analisa como foi pensada e registrada por escrito a expansão portuguesa. Processo que implica a formação de uma cultura imperial da qual a existência de projetos coloniais constitui umas das mais constantes dimensões. Os artigos que compõem a terceira parte do livro, intitulada Iluminismo e práticas de escrita (1697-1808), buscam investigar, em específico, como essa cultura imperial foi construída, ao longo do século XVIII, por relações manuscritas que descreveram e historiaram a presença portuguesa na Ásia, na África e na América. CURTO, D. R. Cultura Imperial e projetos coloniais (séculos XV a XVIII), p. 355 a 476. 
divulgação das Luzes no Reino, como a Tipografia do Arco do Cego (1799), resultou na continuidade do espírito pragmático que caracterizava a produção da ilustração portuguesa do final do século XVIII nas publicações da Impressão Régia do Rio de Janeiro. Continuidade que pode ser identificada pelo grande volume de memórias publicadas sobre História Natural e de Economia Política, que eram, na visão dos letrados portugueses, os dois mais importantes ramos do conhecimento que possibilitariam tirar o Império da crise política e econômica em que se encontrava no final do século XVIII, e devolvê-lo ao esplendor dos seus tempos áureos. A Impressão Régia do Rio de Janeiro mantinha, dessa forma, a função de incentivadora e divulgadora do desenvolvimento científico, a exemplo das instituições congêneres criadas em Portugal no final do século anterior; e é, por isso, interpretada no presente trabalho como herdeira do projeto reformista ilustrado português.

Ao chamar a atenção para o papel de agente histórico protagonizado pela Impressão Régia do Rio de Janeiro, sobressai a tentativa de construção de um discurso de continuidade entre as últimas décadas do século XVIII em Portugal e as primeiras décadas do século XIX no Brasil, por sobre as rupturas impostas pela conturbada conjuntura política. Justificar e legitimar, aos olhos dos portugueses dos dois lados do Atlântico, as mudanças pelas quais passava o Império sob o reinado de D. João foi a função primordial assumida pela Impressão Régia do Rio de Janeiro, para além da heterogeneidade de assuntos abordados em suas publicações e do seu papel sempre ressaltado de introdutora da imprensa no Brasil. E a forma encontrada para fazê-lo foi estabelecendo um nexo de continuidade entre a Ilustração portuguesa e o novo império português na América. Essência mesmo daquilo que aqui eu denomino como o seu trabalho de construção da herança.

Em tempos de disseminação virtual da informação, de luta por uma imprensa que se pretende cada vez menos submetida a ditames políticos e pela livre circulação do conhecimento, diante das constantes tentativas de censura da Internet por parte de diversos governos, este trabalho busca analisar, por uma perspectiva histórica, um tema que se mostra atual ainda hoje: as relações entre cultura e poder. Se, nos dias atuais, o ideal buscado parece ser o de uma cada vez maior desvinculação entre Estado e imprensa; em um ambiente conformado por 
estruturas políticas e sociais de tipo absolutista, como o do Império Português da virada do século XVIII para o XIX, a imprensa era concebida, antes de tudo, como ressalta Juliana Gesuelli Meirelles, como "um instrumento de afirmação da realeza". 45

$$
* * *
$$

Como se estabeleceu na prática a legitimação desse novo império português por parte do trabalho da Impressão Régia do Rio de Janeiro é o objeto dos capítulos que compõem esse trabalho. O trabalho está dividido em três capítulos que procuram abordar três conjuntos documentais significativos e distintos dentro do universo de publicações da Impressão Régia: os dois primeiros capítulos se ocupam do memorialismo científico, sendo o primeiro dedicado aos estudos de História Natural e o segundo às publicações de Economia Política; enquanto o terceiro capítulo privilegia o memorialismo histórico como fonte documental. ${ }^{46}$ Esse três diferentes tipos de publicações formavam boa parte do trabalho também das tipografias criadas no Reino no âmbito da Ilustração portuguesa, o que só vem a reforçar o caráter da Impressão Régia do Rio de Janeiro como herdeira do reformismo ilustrado português. Subjaz aos três capítulos a intenção de chamar a atenção para o estabelecimento da relação entre saber e poder na atuação da tipografia. Assim como apontar para as tensões nascidas da execução do projeto de re-fundação da monarquia nos trópicos, e expressas também por meio de publicações feitas na Europa e na própria América portuguesa.

$\mathrm{O}$ primeiro capítulo, intitulado A Impressão Régia e a Ilustração Portuguesa, apresenta o trabalho da Impressão Régia do Rio de Janeiro como herdeiro das tipografias criadas no ambiente ilustrado português do final do século XVIII, tais como a Tipografia do Arco do Cego, a Impressão Régia de Lisboa e a tipografia da Academia Real das Ciências de Lisboa, investigando os termos da

\footnotetext{
${ }^{45}$ MEIRELLES, op. cit., p. 71

${ }^{46}$ Como vimos no balanço da produção da Impressão Régia do Rio de Janeiro, realizado no início dessa introdução, as publicações da tipografia recobriam uma gama de temas muito maior do que as três grandes linhas de reflexão privilegiadas nesse trabalho. Apesar de estar consciente de que orações gratulatórias e poesias encomiásticas se prestavam igualmente bem à tarefa de difusão das Luzes no Império Português e de construção da metamemória do reinado de D. João, optei por deixá-las de fora do trabalho, recorrendo a elas apenas quando guardavam alguma interface com os conjuntos documentais privilegiados.
} 
construção dessa herança. Para tanto, faz-se necessário compreender a principal característica da ilustração portuguesa: o seu pragmatismo, que buscava responder à situação de crise política e econômica em que se encontrava o Império português no final do século XVIII. Busca-se chamar atenção para o estabelecimento da relação entre Luzes e Estado no interior da Monarquia Portuguesa, dando origem a um projeto de reformas ilustradas para o Império, onde assumiam grande importância o trabalho das tipografias e a arregimentação dos letrados naturais da colônia portuguesa da América, com a função de ajudar no desenvolvimento do conhecimento e exploração das potencialidades naturais da colônia. Ao mesmo tempo, procura-se atentar para a existência de uma constante tensão entre reforma e revolução dentro do Império Português, que se expressa em publicações e na biografia de alguns daqueles letrados, deixando claro que apesar de compartilharem a mesma formação esses homens não defendiam um pensamento homogêneo.

O segundo capítulo, intitulado O Império sob as Luzes da Economia Política, dedica especial atenção às memórias sobre Economia Política publicadas dos dois lados do Atlântico português, que assumiram primordial importância na produção dos reformistas ilustrados devido às discussões que propiciaram acerca da manutenção, organização e desenvolvimento econômico do Império Português. A partir de discussões surgidas na imprensa portuguesa sobre questões tais como o lugar da agricultura na economia do Império, a defesa do livre-comércio e o desenvolvimento ou não de manufaturas, procura-se ressaltar o tom legitimatório, por vezes bastante explícito, de boa parte da produção da Impressão Régia do Rio de Janeiro sobre o assunto, em defesa da nova política econômica adotada pelo Príncipe Regente D. João. Ao mesmo tempo em que o cotejamento entre as memórias publicadas e re-publicadas nos dois lados do Atlântico português, principalmente após 1808, revela perspectivas diferenciadas, e mesmo antagônicas, sobre as medidas econômicas necessárias para o re-erguimento do Império, permitindo entrever as tensões oriundas da efetivação do projeto de recriação do Império na América.

Por fim, o terceiro capítulo, intitulado A Memória de um Poderoso Império, privilegia o trabalho com as publicações de caráter histórico/político da Impressão Régia do Rio de Janeiro publicadas durante o período das invasões francesas em 
Portugal (1808-1811), das quais sobressaíam dois temas intimamente relacionados: as interpretações da transferência da Corte portuguesa para a América e as notícias sobre a guerra na Europa, de uma forma geral, e no Reino, em particular. O que se procura mostrar é que esse memorialismo político tinha o fim não apenas de manter informados os leitores dos dois lados do Atlântico português sobre os acontecimentos da guerra no Reino e na Europa, mas construindo uma representação de D. João como um monarca predestinado, redentor da monarquia portuguesa e da Civilização, assumiam um importante papel político na defesa do novo império português, tecendo uma linha de continuidade entre o passado, presente e futuro de Portugal frente às ameaças de ruptura colocadas pela invasão do Reino pelos franceses e a transferência da Corte para a América. O capítulo pretende ressaltar a construção da metamemória do governo de D. João como mais um aspecto da construção daquela herança a ser apropriada pela Impressão Régia do Rio de Janeiro. Sem nunca deixar de prestar atenção às vozes discordantes, que revelavam outros projetos para o Império. Expressas, nesse caso, nos casos de colaboracionismo com os franceses por parte da nobreza que permaneceu no reino após a transferência da corte. 


\section{A Impressão Régia e a llustração Portuguesa}

No início de 1782, o naturalista italiano Domenico Agostino Vandelli (1735-1816), residente em Lisboa, recebeu uma carta vinda da América portuguesa, mais precisamente da capitania da Bahia, escrita em 18 de outubro do ano anterior. O seu início se parece com o de qualquer carta pessoal entre dois velhos conhecidos, demonstrando que aquela não era uma correspondência esporádica, mas que, pelo contrário, remetente e destinatário mantinham um contato regular:

Com muito gosto e estimação recebi a última carta de V.S. da data de 4 de maio do corrente ano. Eu muito a aprecio, não só pela costumada honra com que me trata, mas muito principalmente pela satisfação que tenho em saber notícias de sua boa saúde, pela qual eu sempre faço todos os bons votos. ${ }^{1}$

$\mathrm{Na}$ continuação desse mesmo parágrafo, ainda comentando a correspondência recebida anteriormente, o autor da carta além de nos dar uma ideia melhor da relação entre os dois correspondentes, traz uma informação interessante. Não eram apenas cartas que atravessavam o Atlântico no último quartel do século XVIII unindo a metrópole portuguesa à sua principal colônia:

Tive, porém, ao mesmo tempo, o grande desprazer com o aviso de não ter recebido o caixote das ervas que com tanto desvelo eu tinha coligido. Consolo-me na esperança de que sempre lhe irá à mão, porque quem o levou era pessoa da confiança de meu pai. Talvez que com os incômodos dos seus negócios na Corte se tenha descuidado da entrega, porque pelo ordinário cada um cuida mais em si do que em encomendas detrimentoras. Eu cá deixei outro caixote igual do que mandei, com as plantas numeradas da maneira do primeiro, esperando receber as instruções que eu pedia a V.S.. Se, com efeito, tardar a entrega, com ordem de V.S. remeterei novo caixote de modo mais seguro. ${ }^{2}$

Informa, então, o correspondente de Vandelli que havia remetido um caixote de ervas coletadas provavelmente na sua terra natal ou, quiçá, em diferentes regiões da colônia portuguesa da América. Encomenda importante, uma

\footnotetext{
${ }^{1}$ LISBOA, J. da S. Carta Muito Interessante do advogado da Bahia, José da Silva Lisboa, para o doutor Domingos Vandelli, Diretor do Real Jardim Botânico de Lisboa, em que lhe dá notícia desenvolvida sobre a Bahia, descrevendo a cidade, as fortificações, a defesa militar, as tropas de guarnição, o comércio e a agricultura, e especialmente a cultura da cana-de-açúcar, tabaco, mandioca e algodão. Dá também as mais curiosas informações sobre a população, os usos e costumes, o luxo, a escravatura, a exportação, as construções navais, o comércio, a navegação para a Costa da Mina, etc. Bahia, 18 de outubro de 1781. Anais da Biblioteca Nacional. v. 32, 1910. p. 494.

${ }^{2}$ Ibid., p. 494/495.
} 
vez que, prevendo a possibilidade do extravio, havia preparado outro caixote idêntico. Nada a estranhar nessa remessa uma vez que Vandelli era então o diretor do Real Jardim Botânico da Ajuda. O naturalista italiano havia sido convidado pelo todo-poderoso Ministro de Estado do rei D. José I (1750-1777), Sebastião José de Carvalho e Melo, futuro Conde de Oeiras e Marquês de Pombal, a participar da reforma da Universidade de Coimbra. Essa reforma fazia parte de uma série de outras que constituíam o projeto de modernização do Estado português que marcou a administração do ministro, e é considerada como o marco de consolidação do processo de assimilação das ideias ilustradas em Portugal.

Difundindo-se pela Europa e América ao longo do século XVIII, a Ilustração não se manifestou através de uma única forma de pensar o homem e a sociedade, nem tampouco consistiu em uma única proposta de mudança em direção a um mesmo objetivo - necessariamente revolucionário. Como afirma Luiz Carlos Villalta, sob o termo Ilustração, na realidade, ocultava-se uma diversidade de ideias e processos, que compreenderam espaços e tempos também variados:

Realidade sociologicamente multifacetada, unificando as elites, alcançando as camadas populares, as Luzes envolveram debates intensos e a defesa de ideias diametralmente opostas. Assim, ao se analisar a Ilustração enquanto um movimento de ideias, logo se evidencia a existência de diferentes posições. ${ }^{3}$

Ressalta Villalta que não se deve interpretar a Ilustração como um projeto intelectual fechado e homogêneo, sendo possível vislumbrar sensíveis diferenças entre os filósofos com relação a diversos temas, inclusive à política. Não obstante, nesse aspecto em particular havia algumas unanimidades. Afirma o autor que além da defesa da liberdade de pensamento e de expressão, da liberdade religiosa e da liberdade de circulação, os filósofos posicionavam-se contrariamente ao despotismo, equiparando-o à morte. Alguns chegavam a defender a legitimidade da rebelião de um povo contra um poder despótico. No tocante à defesa da igualdade, no entanto, esses pensadores não eram tão radicais, limitando-se à igualdade política, na maior parte das vezes, e condenando a igualdade social. ${ }^{4}$

\footnotetext{
${ }^{3}$ VILLALTA, L. C. Reformismo Ilustrado, censura e práticas de leitura: usos do livro na América portuguesa, p. 83/84.

4 “A Ilustração como um todo (...) definia a virtude como o princípio e o fím da política, concebia a existência de uma lei natural anterior a qualquer convenção humana, compreendendo a liberdade como um direito inalienável de todos os homens, assim como o direito à propriedade, à igualdade diante da lei e à participação de cada cidadão na legislação e ainda postulava a ideia de um
} 
Se, por um lado, na França a difusão das Luzes está intimamente relacionada ao advento da Revolução Francesa, que afetou as estruturas políticas da Europa e América, abalando elementos constitutivos do Antigo Regime; por outro lado, nas monarquias ibéricas estas novas ideias geraram a política do reformismo ilustrado (também denominado de absolutismo ilustrado ou despotismo esclarecido). Francisco J. C. Falcon chama a atenção para as diferenças existentes entre as noções de ilustração política e absolutismo ilustrado:

O conceito de Ilustração Política remete às novas concepções acerca das origens da sociedade civil e política, do pacto ou contrato entre governados e governantes, da natureza da soberania, do regime ou sistema político mais racional, das liberdades e direitos inerentes à cidadania, enfim, às ideias desenvolvidas desde pelo menos o final do século XVII e que estão nas origens do liberalismo e da democracia moderna. ${ }^{5}$

Por sua vez, a noção de absolutismo ilustrado tratar-se-ia de uma concepção de Estado inspirada em determinadas ideias dos filósofos da Ilustração, tendo como pressuposto fundamental a educação do príncipe, com o objetivo de conduzi-lo à realização de reformas "ilustradas", ou seja, voltadas para o bemestar de seus súditos. Como chama a atenção o autor, "na prática, esse reformismo buscou a modernização do aparelho de Estado, sua secularização e enriquecimento, sem abrir mão do poder absoluto do monarca e da estrutura social vigente". 6

A situação do Estado português, face à mensagem das Luzes, era bastante incômoda. O século XVIII assistiu ao apogeu do Estado absolutista em Portugal, propiciado pelo auge da exploração de metais preciosos na sua colônia americana. Ressalta o historiador britânico Kenneth Maxwell que foi o ouro do Brasil que permitiu aos monarcas portugueses o luxo de evitar recorrer à antiga instituição

contrato social inicial, ideal ou tácito, entre os indivíduos e o governante, pelo qual os primeiros abdicavam de parte dos seus direitos para instituir um poder, abdicação esta revogável nos casos em que o governante faltasse com seus deveres" (Ibid., p. 91).

5 FALCON, F. J. C. Da Ilustração à Revolução - percursos ao longo do espaço-tempo setecentista, p. 55. Nesse artigo, Falcon procura analisar, uma perspectiva comparada, a penetração das ideias ilustradas nas colônias espanholas e portuguesa da América e suas possíveis relações com a ideia de Revolução. Ele chama a atenção para a existência daquilo que denomina de "refração colonial", que fazia com que as ideias ilustradas adquirissem, no ambiente colonial, sentidos diferentes dos originais: "sujeitas à refração inerente à perspectiva colonial, tais idéias e práticas tendiam a adquirir uma significação exatamente inversa àquela que lhes emprestava a perspectiva metropolitana. Tratava-se de uma forma de inversão embutida na lógica do sistema colonial" (Ibid., p. 58/59).

${ }^{6}$ Ibid., p. 55. 
representativa nacional das Cortes, que não se reuniram uma única vez entre 1698 a $1820 .^{7}$ Por outro lado, a segunda metade do mesmo século se configurou como uma conjuntura de crise política e econômica no Império português. Propiciada, entre outros fatores, pelo encolhimento do seu império ultramarino, iniciado ainda no século anterior, pelo fraco desenvolvimento da sua indústria manufatureira, ao mesmo tempo causa e consequiência da dependência econômica cada vez maior frente à Inglaterra, e pela diminuição dos rendimentos das minas de metais preciosos da América portuguesa. Crise que, ao fim e ao cabo, como procurou demonstrar Fernando A. Novais, era não apenas portuguesa, mas do próprio sistema colonial:

A crise do sistema colonial é, portanto, aqui entendida como o conjunto de tendências políticas e econômicas que forcejavam no sentido de distender ou mesmo desatar os laços de subordinação que vinculavam as colônias ultramarinas às metrópoles europeias. (...) Isto significa, desde logo, que tal crise pode perfeitamente coexistir com uma etapa de franca expansão da produção e do comércio colonial, como é o caso do sistema colonial português desta época. ${ }^{8}$

Dessa forma, política e economicamente dependente da produção colonial, a metrópole portuguesa deveria temer o alastramento nos seus domínios ultramarinos do discurso anticolonialista e dos ideais ilustrados de liberdade e igualdade. Assim, como ressalta Maria de Lourdes Viana Lyra, a difusão das Luzes em território português, evitando a alternativa revolucionária, pautou-se em um programa reformista promovido sob a direção do Estado, que centrou-se na necessidade de reformas educacionais e administrativas, elementos considerados básicos ao progresso dos povos, em geral, e da monarquia portuguesa, em particular:

O reformismo ilustrado português foi sendo pautado na concepção de que cabia ao Estado promover a prosperidade geral, ao mesmo tempo em que se impunha ao governante a tarefa de manutenção da ordem, necessitando para tanto, o fortalecimento de sua ação, através do poder absoluto do soberano virtuoso, porque esclarecido, aquele que saberia encontrar os meios justos para atender às aspirações e aos interesses dos seus súditos. ${ }^{9}$

\footnotetext{
${ }^{7}$ MAXWELL, K. Marquês de Pombal: o Paradoxo do Iluminismo, p. 44.

${ }^{8}$ NOVAIS, F. A. Portugal e Brasil na crise do Antigo Sistema Colonial (1777-1808), p. 13.

${ }^{9}$ LYRA, M. de L. V. A Utopia do Poderoso Império, p. 34. O Dicionário da Língua Portuguesa de Antonio de Moraes e Silva registrava, na sua edição de 1813, o significado de reforma como a mudança em melhor produzida em alguma coisa, no sentido de melhorar o que ia em decadência (SILVA, A. de M e. Diccionário da Língua Portuguesa, v.2, p. 578). Enquanto o termo revolução, apesar de ainda estar relacionado ao seu sentido astronômico ("Movimento pela órbita, giro,
} 
Assim, o reformismo ilustrado português deu origem a uma cultura científica alicerçada em um pragmatismo que estimulava os estudos de finalidade prática, em detrimento dos estudos políticos e filosóficos, tendo como principal objetivo a regeneração econômica do Reino, condição fundamental para evitar a fragmentação do Império. O que aponta para uma articulação entre política e cultura, ou entre saber e poder, no pensamento ilustrado setecentista português. Essa política de Estado tem como marcos a reforma da Universidade de Coimbra, em 1772, durante o ministério de Pombal, e a fundação da Academia Real das Ciências de Lisboa, em 1779, já no reinado de D. Maria I. O caixote de ervas remetido da Bahia para Domenico Vandelli era fruto dessa política reformista ilustrada, que visava o desenvolvimento do conhecimento dos recursos naturais das colônias portuguesas, em especial da sua colônia americana, com a finalidade de desenvolver um novo padrão de exploração colonial que auxiliasse na superação da crise política e econômica em que se encontrava o Império português. $^{10}$

O objetivo do presente capítulo é ressaltar o trabalho da Impressão Régia do Rio de Janeiro como herdeiro do trabalho das tipografias criadas no ambiente intelectual ilustrado português do último quartel do século XVIII. Para investigar como ocorreu na prática a construção dessa herança, faz-se necessário, antes de qualquer coisa, compreender o caráter pragmático da ilustração portuguesa, chamando a atenção para a existência de uma constante tensão entre reforma e revolução dentro do Império português que exercerá importante influência nas escolhas feitas por letrados e estadistas portugueses entre o final do século XVIII e o início do século XIX. Desse caráter pragmático sobressai o papel crucial atribuído ao trabalho das tipografias criadas no âmbito do reformismo ilustrado português, das quais o melhor exemplo é a Tipografia do Arco do Cego. O mesmo pragmatismo, que buscava responder à situação de crise política e econômica em que se encontrava o Império português no final do século XVIII, pode ser

revolução dos astros, planetas", Ibid, p. 629), era comumente relacionado aos horrores da Revolução francesa de 1789.

${ }^{10}$ A expressão é de Ana Rosa Cloclet da Silva, que afirma que: "o desenvolvimento de um novo padrão de exploração colonial, uma vez atestada a falência de seus mecanismos clássicos constituiu-se, portanto, na problemática mobilizadora do pensamento ilustrado acadêmico". SILVA, A. R. C. da. Inventando a nação: intelectuais ilustrados e estadistas luso-brasileiros na crise do Antigo Regime português 1750-1822, p. 125/126. 
encontrado na atuação da Impressão Régia do Rio de Janeiro. O que nos permite caracterizá-la como herdeira do reformismo ilustrado português.

\section{1.}

\section{Lusitanas Luzes}

O correspondente de Domenico Vandelli era José da Silva Lisboa (17561835). Nascido na Bahia, oriundo de família de origem humilde, entrou em contato com o naturalista italiano no período em que estudou na recém-reformada Universidade de Coimbra. Como ressalta Tereza Cristina Kirschner, Silva Lisboa matriculou-se naquela Universidade em 1774, apenas dois anos após a elaboração dos seus novos estatutos, que receberam licença para serem implementados em 28 de agosto de 1772, em substituição aos velhos, suspensos desde 25 de setembro do ano anterior, obtendo o bacharelado em Direito Canônico e Filosofia em 1779. ${ }^{11}$

Os novos estatutos visavam modernizar o método de instrução das quatro áreas de formação pré-existentes na Universidade de Coimbra: As Faculdades de Teologia (Curso Teológico), de Medicina (Curso Médico) e de Cânones e Leis (que compunham os Cursos Jurídicos). Como explica Flávio Rey de Carvalho: "a esfera de atuação da teologia foi redefinida, separando-se dela a filosofia moral; as jurisprudências civil e canônica passaram por processo de reatualização geral e a medicina adquiriu feição mais pragmática". ${ }^{12}$ Área de formação de Silva Lisboa, Cânones e Leis constituíam faculdades separadas e com diplomas distintos por tratarem de diferentes objetos. O Direito Canônico se ocupava da "direção da vida cristã", enquanto o Direito Civil se ocupava da "tranquilidade da vida civil". Nos dois primeiros anos do curso jurídico, no entanto, eram oferecidas as mesmas disciplinas para os estudantes de Cânones e Leis, as chamadas cadeiras pequenas: Direito Natural, Público Universal e das Gentes; História Civil dos Povos; Direito Romano e Português; História da Igreja Universal e Portuguesa; e História do Direito Canônico Comum e próprio destes Reinos. Com a reforma, os estudos jurídicos tiveram a sua duração reduzida de oito para cinco anos,

\footnotetext{
${ }^{11}$ KIRSCHNER, T. C. José da Silva Lisboa, Visconde de Cairu: Itinerários de um ilustrado lusobrasileiro, p. 19.

${ }^{12}$ CARVALHO, F. R. de. Um Iluminismo Português? A reforma da Universidade de Coimbra (1772), p. 63.
} 
incorporando o estudo de fontes portuguesas. Segundo síntese de Flávio Rey de Carvalho:

A nova Faculdade de Leis voltava-se à preparação teórico-prática dos estudantes, para que estes estivessem, ao final dos cinco anos do curso, aptos a administrarem corretamente a justiça, sabendo interpretar e aplicar, de maneira uniforme, as leis aos fatos vividos no contexto forense do reino português. ${ }^{13}$

A mais significativa inovação na reforma da Universidade de Coimbra consistiu, porém, na criação das faculdades de Matemática e Filosofia. Esta última, com duração de quatro anos, estava organizada em dois eixos de disciplinas: o primeiro oferecia cursos das matérias voltadas para a filosofia racional e moral, como as tradicionais Metafísica, Lógica e Ética, a serem cursadas no primeiro ano; e o segundo, ministrava cursos ligados à nova filosofia natural. Por esse termo se compreendia o conjunto de conhecimentos alcançados pela observação da natureza por meio do novo método experimental newtoniano, que compunham o currículo dos três anos subsequentes e que formavam o chamado Curso de Física, divididos da seguinte forma: no segundo ano estudavase a Cadeira de História Natural (que, por sua vez, compreendia as disciplinas de Botânica, Zoologia e Mineralogia), no terceiro a de Física Experimental e no último a de Química Teórica e Prática. Segundo síntese de Flávio Rey de Carvalho:

Conforme pode ser constatado, à filosofia natural (...) seria dedicada a maior parte das aulas ministradas na recém-criada Faculdade de Filosofia, cujos conteúdos, se analisados sob uma perspectiva sintética e panorâmica, voltavam-se à habilitação dos estudantes em três domínios: "reflexão", para combinar os fatos (primeiro ano - cadeira de filosofia racional $e$ moral); a "observação", para coletar os fatos da natureza física (segundo ano - cadeira de história natural); a "experimentação", para comprovação das combinações racionais dos fatos (terceiro e quarto anos - cadeiras de física experimental e química teórica e prática, respectivamente). ${ }^{14}$

Além das disciplinas próprias dos seus cursos, os estudantes de Leis e Cânones, Medicina e Matemática deviam cursar, nos dois primeiros anos, cadeiras

\footnotetext{
${ }^{13}$ Ibid., p. 84.

${ }^{14}$ Ibid., p. 114. Ressalta Tereza Kirschner que a falta de professores preparados para o ensino de filosofia natural em Portugal fez com que as disciplinas viessem a ser ministradas por estrangeiros, como o próprio Vandelli, nas de história natural e química, o veneziano Michele Franzini na de Matemática e Giovanni Antonio dalla Bella, natural de Pádua assim como Vandelli, na de física. O grupo de naturalistas italianos que vieram com Vandelli contava ainda com o piemontês Michele António Ciera. KIRSCHNER, op. cit., p. 31.
} 
nas faculdades de Filosofia e Matemática. Os alunos de Leis e Cânones assistiam, no primeiro ano, à cadeira de Filosofia Racional e Moral na Faculdade de Filofia; e no segundo, às cadeiras de História Natural, também na Faculdade de Filosofia (onde, provavelmente, Silva Lisboa foi aluno de Vandelli) e de Geometria, na Faculdade de Matemática. Dessa forma, ao lado dos estudos tradicionais de Direito e Teologia, a exploração e o conhecimento do mundo natural passavam a fazer parte da paidéia ilustrada.

Fez parte da reforma da Universidade de Coimbra também a criação de estabelecimentos para o ensino prático das ciências que incluía um Observatório Astronômico, para a Faculdade de Matemática e um Museu de História Natural e um Jardim Botânico para a Faculdade de Filosofia. A reforma da Universidade de Coimbra foi responsável, assim, pela divulgação em larga escala do método empírico-experimental em Portugal, configurando uma aproximação com os esquemas mentais ilustrados e evidenciando uma nova concepção de ciência em Portugal, que tinha a intenção de substituir o método de ensino escolástico, mantido pela Companhia de Jesus na Universidade entre 1598 e 1771, e considerado a causa do declínio da instrução praticada naquela instituição. Como afirma Tereza Kirschner:

\begin{abstract}
A cuidadosa organização e o detalhamento dos cursos que se encontram nos estatutos revelam a intenção de uma reforma significativa da mentalidade portuguesa bem como uma admirável coerência interna, cujo eixo norteador era, no campo jurídico, a racionalização do direito e no campo filosófico, a valorização do conhecimento da natureza para fins de enriquecimento do Estado. (...) Enquanto a reforma dos estudos jurídicos possibilitou uma nova representação do poder régio, o conhecimento dos reinos da natureza propiciado pela filosofia natural consistiu um instrumento importante para a exploração dos recursos naturais do império. Ambos os saberes, agora obrigatórios na formação dos bacharéis, relacionavam-se e dirigiam-se para o mesmo propósito. ${ }^{15}$
\end{abstract}

Além dos estrangeiros convidados pelo Marquês de Pombal, e mesmo anteriores a esses, tiveram grande importância nesse processo de renovação do ambiente intelectual português letrados e estadistas que, desde o início do século XVIII, estudavam e atuavam no exterior, e ficaram conhecidos em Portugal pelo nome de estrangeirados. Entre os quais incluem-se os nomes do diplomata D.

\footnotetext{
${ }^{15}$ Ibid., p. 32/33.
} 
Luís da Cunha (1662- 1749), ${ }^{16}$ de Luís Antônio Verney $(1713-1792),{ }^{17}$ e de Antonio Nunes Ribeiro Sanches $(1699-1783) .{ }^{18}$ A sua trajetória políticointelectual, seu contato com as ideias divulgadas em diferentes cortes, fez com que eles perspectivassem a situação do Reino com base no confronto estabelecido entre a realidade nacional e os diversos contextos da Ilustração europeia. Segundo avaliação desses estadistas letrados, o principal obstáculo a ser superado no processo de inversão da decadência política e econômica do Reino seria a superação do seu atraso cultural. Segundo síntese de Ana Rosa Cloclet, os estrangeirados seriam aqueles indivíduos que, ausentando-se de Portugal,

\begin{abstract}
"Contaminavam-se" com as idéias ilustradas, ou que, por professarem idéias críticas à cultura castiça, eram excluídos do seio da sociedade portuguesa. Juntamente com os "cristãos-novos" - vistos como "impuros na fé" e mesmo no "sangue" - representavam uma heresia à ordem estabelecida e, ainda que com ela comungassem em muitos aspectos, reclamaram sempre a condição de difusores da cultura estrangeira e das técnicas do tempo, no sentido de alinhar o Reino às nações européias "cultas". ${ }^{19}$
\end{abstract}

Estrangeirado também era Sebastião José de Carvalho e Melo (1699-1782).

Enviado por D. João V em missão diplomática à corte inglesa, em 1738, Carvalho e Melo lá permaneceu até 1745 quando passou à corte de Viena. Voltou a Portugal em 1749 atendendo ao chamado da rainha regente Maria Ana da Áustria, durante a enfermidade fatal de seu marido. Com a morte de D. João V foi nomeado por D. José I Ministro dos Negócios Estrangeiros e da Guerra (por

\footnotetext{
${ }^{16}$ Embaixador nas cortes de Londres (1715-1719), Madri (1719-1720), Paris (1720-1728 e 17361749) e Haia (1728-1736), delegado nas negociações do Tratado de Utrecht, assinado em 1715, entre Portugal e Espanha.

${ }^{17}$ Graduado em Artes e Teologia no Colégio da Madre de Deus, em Évora, e em Teologia e Jurisprudência Civil em Roma. Em 1742, foi designado pelo papa arcediago da Sexta Cadeira na Catedral de Évora, lugar que assumiu em Roma, onde permaneceu até a sua morte. A historiografia aponta o seu Verdadeiro Método de Estudar (1746) como um dos mais importantes marcos de afirmação do ideário das Luzes em Portugal. A respeito, ver NOVAIS, op. cit., p. 221/222; FALCON, F. J. C. A Época Pombalina: Política Econômica e Monarquia Ilustrada, p. 330 a 343 ou VILLALTA, op. cit., p. 111 a 115.

${ }^{18}$ Estudou Medicina e Direito na Universidade de Coimbra e doutorou-se em Medicina na Universidade de Salamanca. Obrigado a ausentar-se de Portugal em virtude de sua condição de cristão-novo, empreendeu longa viagem pela Europa, instalando-se em Paris em 1747, onde conquistou renomada reputação entre os letrados, chegando a colaborar na elaboração da Enciclopédia de d'Alembert e Diderot.

${ }^{19}$ SILVA, A. R. C. op. cit., p. 39. Segundo essa autora, os estrangeirados seriam referidos pela historiografia como "a própria essência do fenômeno ilustrado luso" (Ibid.). José Luís Cardoso, por outro lado, critica a idéia que responsabiliza exclusivamente os estrangeirados pela introdução das Luzes em Portugal, "sem que se cuide de admitir que possa existir uma dinâmica interior que não seja a da decadência ou a do abismo" (CARDOSO, J. L. O pensamento econômico em Portugal nos finais do século XVIII: 1780-1808, p. 44).
} 
decreto de 31 de julho de 1750), ${ }^{20}$ e depois a Secretário dos Negócios do Reino (31 de agosto de 1756). Desse modo, conforme explica Kenneth Maxwell, Pombal tomou posse como Secretário com muita experiência diplomática, um conjunto de ideias bem formulado e um círculo de amigos e conhecidos que incluía algumas das figuras mais eminentes nas ciências, especialmente dentro da comunidade dos expatriados portugueses, muitos dos quais haviam sido forçados a deixar Portugal por causa da Inquisição:

As preocupações de Pombal também refletiam as de uma geração de funcionários públicos e diplomatas portugueses que haviam meditado muito sobre a organização imperial e as técnicas mercantilistas que acreditavam que houvessem ocasionado o poder e a riqueza surpreendentes e crescentes da França e da Grã-Bretanha. ${ }^{21}$

O sentimento de defasagem cultural, assim como a crise econômica e política deram origem a uma política reformista de caráter pragmático, onde a reforma da Universidade de Coimbra obedecia ao interesse mais amplo da Coroa portuguesa de modernização do Reino, tendo em vista a sua regeneração econômica. $^{22}$ Fernando A. Novais afirma que, mais do que uma defasagem cronológica na incorporação das novas ideias, o que havia era uma resistência do meio lusitano à sua fecundação:

Portugal não estava apenas geograficamente, mas também espiritualmente excêntrico aos grandes movimentos de idéias que percorriam a civilização do Antigo Regime europeu. Pelo menos era o que pretendia a barragem inquisitorial, com o fim de guardar o Reino nos cânones da mais estrita ortodoxia. ${ }^{23}$

A censura em Portugal é anterior ao estabelecimento da Inquisição, mas intensificou-se a partir do seu surgimento, em 1536, quando os temas religiosos passaram a necessitar da aprovação do Santo Ofício para serem impressos. A partir do reinado de D. Sebastião (1554-1578) passou a vigorar um sistema tripartido de censura, que passou a ser exercida conjuntamente pelo Ordinário (o

${ }^{20}$ Por indicação de D. Luís da Cunha no seu famoso Testamento Político, publicado pela Impressão Régia de Lisboa em 1820 com o título de Testamento Político ou carta escrita pelo grande D. Luiz da Cunha ao senhor rei D. José I, antes do seu governo.

${ }_{21}^{21}$ MAXWELL, K. Marquês de Pombal: O Paradoxo do Iluminismo, p. 10.

${ }^{22}$ Flávio Rey de Carvalho questiona que esse diagnóstico de atraso cultural, afirmando que não era hábito entre os portugueses do século XVIII estabelecer comparações entre a situação do cultural do Reino e a de outras nações. Segundo esse autor, o "mal-estar luso", porém, era sentido antes na comparação com o passado glorioso do Império, como potência colonial que foi no período anterior à União Ibérica: "A confrontação gerou um complexo de inferioridade, não em relação ao caminho diferente traçado pelos demais países da Europa durante os séculos XVI e XVII, mas à perda do status vivido no passado". CARVALHO, op. cit., p. 22.

${ }^{23}$ NOVAIS, op. cit., p. 219. 
juízo eclesiástico existente em cada diocese sob o comando do bispo), pelo Santo Ofício e pelo Desembargo do Paço. Os três tribunais agiam independentemente, cada um com suas regras e princípios próprios. Os dois primeiros se ocupavam da análise das obras de caráter religioso, enquanto o último ocupava-se das matérias de caráter laico, mas a publicação de qualquer impresso dependia das três licenças. Explica Luiz Carlos Villalta que devido a esse arranjo os clérigos tinham a primazia no exercício da censura, pois eram juízes de dois dos três tribunais e, por isso, concedeu-se prioridade ao combate à heresia, estando a censura no mundo português profundamente associada à Reforma Católica até o advento da reforma pombalina. ${ }^{24}$ Afirma esse autor que o Índex inquisitorial de 1624, o último publicado em Portugal até as reformas pombalinas, por medo da difusão do protestantismo proibiu a leitura e circulação de livros em hebraico, alemão, flamengo e inglês (mesmo os não arrolados no Índex) e recomendou cautela com os franceses, fechando com isso as portas de Portugal para o contato com alémPireneus. $^{25}$

Graça Almeida Rodrigues ao estudar a censura literária em Portugal, afirma que ao longo dos séculos XVI e XVII Portugal foi o país católico mais estritamente protegido contra aquilo que se considerava heresia e imoralidade literária. Sendo que "a partir de 1551, Portugal ocupou uma posição de avantgarde entre os países católicos no respeitante à censura" ${ }^{26}$ Referindo-se à ação da censura inquisitorial na Universidade de Coimbra pré-reforma pombalina, afirma Graça Almeida Rodrigues que os professores daquela instituição encontravam-se em um verdadeiro espartilho intelectual:

Manuscritos da Torre do Tombo contêm numerosas censuras a teses universitárias, levadas a cabo pelos censores Fr. Francisco Ribeiro, Fr. Antônio Pacheco e D. Antônio dos Mártires que, segundo a fórmula oficial 'repugnam à nossa Santa Fé e bons costumes'. Nestas teses, escritas em latim, são apontados os menores desvios à autoridade consagrada. ${ }^{27}$

Em abril de 1768, o Marquês de Pombal criou a Real Mesa Censória, retirando do tribunal do Santo Ofício e do Ordinário a prerrogativa de responsáveis pela censura da literatura religiosa como parte da estratégia para

\footnotetext{
${ }^{24}$ VILLALTA, L. C. Censura literária e inventividade dos leitores no Brasil Colonial, p. 46/47.

${ }^{25}$ Ibid., p. 52

${ }^{26}$ RODRIGUES, G. A. Breve história da censura literária em Portugal. p. 26.

${ }^{27}$ Ibid., p. 28.
} 
retirar das mãos da Igreja a sua ingerência sobre a formação das mentalidades em Portugal, e tornando-a um instrumento do Estado absolutista. Como afirma Graça Rodrigues:

A Real Mesa Censória, substituindo a Censura Inquisitorial, transfere para o Estado o exercício da Censura. Os censores passam a ser censores régios. À Mesa foram concedidas não só as atribuições de censura oficial e fiscalização de todas as publicações nacionais e estrangeiras, mas também a de elaboração de um Novo Îndice Expurgatório que substituísse o índice de $1624 .{ }^{28}$

Segundo Kenneth Maxwell, as reformas educacionais pombalinas, cuja culminância se encontra na reforma da Universidade de Coimbra, visavam três objetivos principais: trazer a educação para o controle do Estado, secularizar a educação e padronizar o currículo. ${ }^{29}$ Procurou-se proceder, por meio delas, a uma laicização do saber científico em Portugal. O grau de laicização alcançado nesse processo, no entanto, é controverso. Tanto na Metrópole quanto na Colônia, a presença dos eclesiásticos continuaria sendo atuante no encaminhamento das reformas pombalinas. Francisco Falcon chama atenção para o fato de que, embora secular em sua essência, o reformismo ilustrado dos déspotas esclarecidos não era propriamente laicizante. A racionalização pretendida visava dotar o Estado de um poder ampliado sobre os súditos do príncipe através da maior eficiência administrativa, pela formação de um novo corpo de funcionários régios ilustrados que atuassem na burocracia estatal do Império português. Seria temerário, porém, atribuir às práticas reformistas dos governos ilustrados um caráter laico, no sentido de rejeição da fé religiosa, ou, nos estados católicos, de ruptura entre 'o trono e o altar':

\footnotetext{
${ }^{28}$ Ibid., p. 36. Afirma Francisco Falcon que a atuação da Real Mesa Censória é de extraordinária importância no ambiente intelectual de então, diversificando-se em direções como a instrução pública, a condenação do sigilismo, a fiscalização sobre o Colégio dos Nobres, o exame de Breves e Bulas Apostólicas, e, obviamente, o exame de livros nacionais e estrangeiros que se pretendesse fazer publicar ou simplesmente circular no país (FALCON, F. J. C. A Época Pombalina, p. 443). Reforçando a ideia de Rui Tavares, citada na Introdução deste trabalho, de que censura e propaganda caminham sempre lado a lado, é importante lembrar que, ao lado da criação da Real Mesa Censória, também foi obra do Marquês de Pombal o estabelecimento da Impressão Régia de Lisboa, pelo alvará de 24 de dezembro de 1768.

${ }^{29}$ MAXWELL, K. Marquês de Pombal: O Paradoxo do Iluminismo. p. 110. Nesse processo, a dissolução da Companhia de Jesus representou o fato mais decisivo no estabelecimento de uma instrução pública com caráter secular e nacional. Pombal imputava a decadência de todos os ramos das ciências ao domínio que os jesuítas possuíam sobre o ensino no Reino e no Ultramar. Dessa forma, a dissolução da Ordem significou a quebra do obstáculo à introdução das novas ideias.
} 
Resvalaríamos para o pior dos anacronismos se fôssemos contrapor, quer no Portugal pombalino, quer no pós-pombalino, de forma exclusivamente mecânica e arbitrária, o Estado à Igreja, sem precisarmos ou atentarmos para as inúmeras mediações de todo tipo que representavam, afinal, a possibilidade mesma e também os limites da efetivação das mudanças e reformas que formam o essencial da prática ilustrada. ${ }^{30}$

O fato de Pombal inaugurar uma série de reformas inspiradas nas Luzes do século e tendentes a fecundar a modernização portuguesa com a finalidade última de reforçar os próprios fundamentos do Estado absolutista, foi entendida por alguns autores como um dos muitos paradoxos do projeto político daquele ministro, que "bebia nas Luzes seletiva e fragmentariamente, as ideias que melhor se ajustavam aos objetivos de uma prática reformista, concebida e implementada pelo próprio Estado absolutista". ${ }^{31}$ Esse paradoxo, porém, fazia parte da forma mesma como foram absorvidas as ideias ilustradas em Portugal. Seria, como conclui Oswaldo Munteal, "a chegada ao entendimento da ciência como uma aliada, e não como um símbolo do ateísmo e da destruição dos valores monárquicos". 32

Frente ao contexto de crise econômica, o reformismo ilustrado português incentivava o conhecimento e aproveitamento das potencialidades da exuberante natureza tropical das suas colônias, buscando incentivar o comércio e restabelecer os fluxos das riquezas coloniais em direção à Metrópole. Em particular da América portuguesa, pela diversidade de sua flora, pela descoberta de uma fauna especial e exótica e pelo papel central que ocupava no processo de acumulação de riquezas da Metrópole:

A orientação dominante no campo da investigação científica era para que se procedesse a um levantamento de exemplares da flora e da fauna das colônias ultramarinas visando, principalmente, um mercado de produtos comerciáveis até então inexplorados. Esta motivação inicial de certo promoveu um estímulo para o estudo das Ciências Naturais. ${ }^{33}$

Para viabilizar tal conhecimento, foram de fundamental importância as expedições de investigação científica feitas nos territórios do ultramar, também conhecidas pelo nome de viagens filosóficas, cujo objetivo era realizar o inventário dos recursos naturais desses territórios e as suas aplicações

\footnotetext{
${ }^{30}$ FALCON, F. J. C. A Época Pombalina, p. 431.

${ }^{31}$ SILVA, A. R. C. da, op. cit. p. 92.

${ }^{32}$ MUNTEAL FILHO, O. Domenico Vandelli no Anfiteatro da Natureza: A Cultura Científica do Reformismo Ilustrado Português na Crise do Antigo Sistema Colonial (1779-1808), p. 213.

${ }^{33}$ Ibid., p. 175.
} 
econômicas, assim como o emprego de correspondentes residentes nas colônias. Domenico Vandelli foi o responsável, em 1783, pelas quatro primeiras expedições científicas que saíram de Lisboa em direção ao Ultramar, protagonizadas por exalunos seus que trabalhavam com ele no Museu de História Natural e Jardim Botânico da Ajuda, organizando as remessas de produtos naturais que chegavam a Lisboa, vindas das colônias. ${ }^{34}$ Assim, os jardins botânicos d'Ajuda (criado em 1768) e da Universidade de Coimbra foram instituições de suma importância para auxiliar os estudos da História Natural. Como informa Oswaldo Munteal, embora no século XVIII já proliferassem por Lisboa e seus arredores, quintas e jardins onde se colecionavam plantas raras, o Jardim d'Ajuda foi o primeiro a ser criado em novos moldes com fins marcadamente de ensino, em que as plantas deixam de ser colecionadas desordenadamente, passando a obedecer às normas indicadas pelos taxonomistas da época. Dessa forma, o trânsito de caixotes com amostras de plantas entre Brasil e Portugal, como o que Vandelli deveria ter recebido da Bahia, era o resultado dessa política de fomento do conhecimento e exploração das potencialidades naturais da América portuguesa. Como afirma Oswaldo Munteal:

No último quartel do século XVIII é extremamente significativo o investimento do Estado luso no envio de missões botânicas às possessões ultramarinas com o objetivo de estudar as flores locais, e de lá trazerem herbários e plantas vivas para o Jardim Botânico d'Ajuda. Especialmente aquelas que julgavam os naturalistas e autoridades ilustradas de maior utilidade para o estudo e aplicação da medicina, nas artes e na economia. ${ }^{35}$

Como nos informa o trecho da carta recebida por Vandelli citado anteriormente, as plantas remetidas pelo seu correspondente da Bahia estavam organizadas e classificadas cientificamente. No mesmo ano em que Silva Lisboa

\footnotetext{
${ }^{34}$ João da Silva Feijó (1760-1824) e Joaquim José da Silva, ambos naturais do Rio de Janeiro, partiram respectivamente para Cabo Verde e Angola; enquanto Manoel Galvão da Silva e Alexandre Rodrigues Ferreira (1756-1815), ambos nascidos na Bahia, foram, respectivamente, para Goa e Moçambique e para o Brasil. A grande viagem filosófica de Alexandre Rodrigues Ferreira pela região amazônica durou quase uma década. Retornando a Lisboa no início de 1793, foi nomeado Oficial da Secretaria de Estado dos Negócios da Marinha e Domínios Ultramarinos e vice-diretor do Real Museu de História Natural e Jardim Botânico da Ajuda.

${ }^{35}$ MUNTEAL FILHO, op. cit., p. 114. Os Jardins das Luzes tinham uma dupla função: 1) local onde filósofos, jardineiros e naturalistas se encontravam, eram retratados ou, mesmo, apenas idealizados como pertencentes ao mundo botânico; e 2) centro de investigações e de classificação de plantas úteis e exóticas trazidas do Ultramar. Dessa forma, os Jardins Botânicos d'Ajuda e da Universidade de Coimbra tiveram papel decisivo no processo de classificação e exposição dos espécimes trazidos do ultramar português, assim como na coordenação dos demais estabelecimentos científicos, sendo, portanto, os centros deflagradores dos resultados obtidos nas investigações sobre o mundo natural nas colônias (Ibid., p. 56 a 134).
} 
faz a remessa do seu caixote de ervas para Vandelli, são publicadas em Portugal as Breves Instruções dadas pela Academia de Ciências de Lisboa aos seus correspondentes, de autoria do próprio Vandelli, que fixava os procedimentos para a coleta e envio de produtos de história natural para Portugal. ${ }^{36}$ Em 1819, a Impressão Régia do Rio de Janeiro publicou a tradução de uma Instrução sobre a maneira correta de coletar, conservar e remeter produtos de História Natural, organizada no ano anterior pela administração do Real Museu de História Natural de Paris. ${ }^{37}$ A tradução do manual francês é precedida pelas Reflexões sobre a História Natural do Brasil e sobre o estabelecimento do Museu e Jardim Botânico na cidade do Rio de Janeiro, que parecem ter sido escritas próximo à data de publicação, na qual o autor procura ressaltar a importância do estudo da História Natural, principalmente frente à especificidade e diversidade da flora e fauna da América portuguesa, chamando sempre a atenção para a sua utilidade econômica:

\begin{abstract}
A experiência tem mostrado que há produtos de cada um dos três reinos da Natureza exclusivos de certas capitanias e paragens do Brasil. O que era de esperar porquanto esta parte do Novo Mundo se acha colocada debaixo da zona tórrida e se estende até a temperada, gozando por isso das vantagens de muitos climas, e sendo o seu terreno favorável a quase todas as produções do Globo. Em tão vasta extensão, as estações e a temperatura oferecem necessariamente mui grandes variedades. (...) Destas óbvias considerações, que com outras muitas se poderiam reforçar, é evidente que devemos pôr todo o cuidado em conhecer os produtos
\end{abstract}

\footnotetext{
${ }^{36}$ VANDELLI, D. Breves Instruções aos correspondentes da Academia de Ciências de Lisboa, sobre as remessas dos produtos e notícias pertencentes à História da Natureza para formar um Museu Nacional. Lisboa: Oficina Typografica, 1781. Segundo Tereza Cristina Kirschner, muitos exemplares das Breves Instruções foram enviados para as diferentes colônias portuguesas e esperava-se que os bacharéis formados em Coimbra, espalhados pelo império colaborassem para a formação do Real Museu de História Natural da Ajuda. Um desses exemplares, provavelmente, foi entregue a José da Silva Lisboa (KIRSCHNER, op. cit., p. 56). Manoel Salgado Guimarães lembra que o texto central para organizar os procedimentos das viagens filosóficas como parte da cultura ilustrada em Portugal já havia sido redigido por Vandelli em 1779 e intitulava-se Viagens filosóficas ou dissertação sobre as importantes regras que o Filósofo Naturalista, nas suas peregrinações deve principalmente observar (GUIMARÃES, M. L. S. As luzes para o Império: História e Progresso nas páginas de O Patriota, p. 87).

${ }^{37}$ Instrução para os viajantes e empregados nas colônias sobre a maneira de colher, conservar e remeter os objetos de História Natural. Arranjada pela administração do Real Museu de História Natural de Paris. Traduzida por Ordem de Sua Majestade Fidelíssima, expedida pelo excelentíssimo Ministro e Secretario de Estado dos Negócios do Reino, do original francês impresso em 1818. Aumentada em notas de muitas das instruções aos correspondentes da Academia Real das Ciências de Lisboa, impressas em 1781; e precedida de algumas reflexões sobre a História Natural do Brasil e estabelecimento do Museu e Jardim Botânico em a Corte do Rio de Janeiro. Rio de Janeiro: Impressão Régia, 1819. A Instrução foi publicada sem o nome do autor, mas Rubens Borba de Moraes e Ana Maria de Almeida Camargo atribuem a sua organização a José Feliciano de Castilho, lente da faculdade de Medicina da Universidade de Coimbra então residente no Rio de Janeiro. CAMARGO, A. M. de A. \& MORAES, R. B. de. Bibliografia da Impressão Régia do Rio de Janeiro. vol. 2. p. 221/222.
} 
naturais desta importante parte do Mundo, e esperar deles grandes resultados para as ciências e para as artes. ${ }^{38}$

$\mathrm{O}$ autor interpola as suas Reflexões com algumas Notícias pertencentes à História Natural, que nada mais são do que extratos retirados das Breves Instruções de Vandelli. Entre as instruções sobre a forma de se remeter os produtos de coleta, recomendava-se aos correspondentes que dentro dos caixotes enviassem uma relação exata e detalhada de todas as coisas que eles continham, tal como parece ter feito Silva Lisboa na sua remessa para Vandelli:

\begin{abstract}
Supondo que cada uma das espécies vem acomodadas separadamente e distintas com números diversos, na relação, debaixo dos mesmos números, se declarará: $1^{\circ} \mathrm{o}$ nome, tanto indígena como estrangeiro da mesma espécie, e o nome com que a costumam distinguir os naturalistas; $2^{\circ}$ Notar-se-ão todas as suas qualidades mais atendíveis e particularmente as menos conhecidas. A respeito dos animais que remete, expressará todos os fatos constantes e uniformes que distinguem mutuamente as diferentes espécies, como é tudo que pertence à sua geração, lugares que habitam, tempo de coito e de parto, instinto, artifícios, alimentos, doenças, duração e etc. Mas, com mais particularidade se demorará sobre as utilidades que do uso deles pode resultar para a vida humana. Na relação das qualidades dos vegetais declarará os lugares do seu nascimento, a estação própria da sua plantação, o tempo da sua frutificação, os usos que a experiência tiver mostrado se podem fazer deles para o alimento, para a medicina e para todas as mais artes. Entre as qualidades finalmente dos minerais de que manda amostras, não se esquecerá o correspondente de expressar os lugares em que se acham, a profundidade de seus veios, a natureza dos terrenos circunvizinhos e os usos que já tem no país e os que podem ter na sociedade. ${ }^{39}$
\end{abstract}

A tradução do manual francês também vinha acrescida de dezenove Notas extraídas daquelas Breves Instruções de Vandelli, cuja maior parte dizia respeito à preparação dos espécimes animais para o seu envio. Em geral, detalham os procedimentos descritos no manual francês, os complementando ou até mesmo os corrigindo. ${ }^{40}$ Dessa forma, a publicação de 1819 , que misturava a tradução do

\footnotetext{
${ }^{38}$ Instrução para os viajantes e empregados nas colônias sobre a maneira de colher, conservar e remeter os objetos de História Natural, p. VII/VIII. Nessa parte da obra o autor, ao refletir sobre o estabelecimento do Jardim Botânico do Rio de Janeiro, propõe que cada uma das capitanias tivesse o seu próprio Museu de História Natural e enviassem exemplares das suas produções naturais para o Mиseu Geral Brasílico, que ficaria na capital do Império. Faz também uma relação das pesquisas até então realizadas sobre a História Natural do Brasil e dos nomes dos naturalistas que naquele momento residiam e pesquisavam no Brasil (p. XX a XXXIII). Assim como das medidas tomadas diretamente pela Coroa para o incentivo das pesquisas de História Natural. A principal das quais, o estabelecimento do Real Jardim Botânico da Lagoa Rodrigo de Freitas.

${ }^{39}$ Instrução para os viajantes e empregados nas colônias sobre a maneira de colher, conservar e remeter os objetos de História Natural, p. XII/XIII.

${ }^{40}$ Por exemplo, com relação à preparação de grandes animais, o manual francês afirmava que para aqueles que tivessem sido mortos em lugares remotos, de onde fosse difícil conservá-los e transportá-los, bastava que se remetesse a pele, a cabeça e os pés. Mas a nota número 2 retifica a instrução francesa: "Mas, como só as peles não bastam para dar uma idéia justa da forma e postura
} 
manual francês redigido no ano anterior, as Reflexões sobre o estado das pesquisas de História Natural no Império Português e as Notas retiradas do manual de Vandelli, pareciam querer demonstrar como os naturalistas portugueses estavam em dia com os procedimentos utilizados no resto da Europa, em particular na França. Mais do que isso, dava aos naturalistas portugueses uma impressão de pioneirismo no assunto, uma vez que as Breves Instruções de Vandelli precediam ao manual francês em quase 40 anos!

Além dos naturalistas enviados às colônias, a ilustração portuguesa contava também com a colaboração de letrados residentes no ultramar. Ex-estudantes da Universidade de Lisboa, graduados nas mais diversas áreas, sendo muitos exalunos de Vandelli, como era o caso de José da Silva Lisboa. Após retornar de Portugal, Silva Lisboa, além de procurar ganhar a vida como advogado, mantinhase como correspondente do antigo professor, fornecendo-lhe informações sobre a História Natural da sua capitania de origem. Esse o principal motivo da carta enviada a Vandelli no final de 1781. Como explica logo no segundo parágrafo da sua carta, Lisboa procurava humildemente se desincumbir da tarefa, solicitada pelo naturalista italiano, de descrever-lhe a sua capitania natal:

\begin{abstract}
A respeito da descrição da Bahia que V.S. me ordena que eu faça (eu digo ingenuamente), me vejo um pouco embaraçado em obedecer-lhe, temendo que não corresponda nem aos desejos de V.S. nem à idéia que honrosamente tem formado da minha mediocridade. Eu conheço muito a profundidade de V.S. para me persuadir que não se contentará com toques superficiais das coisas, e sei que o que me manda supõe luzes superiores às minhas forças atuais. Eu tenho já, mais de uma vez, representado a V.S. a situação oprimida a que me reduziu nestas terras a dureza da minha sorte. Obrigado a ganhar a minha subsistência da mendiga advocacia, vida pouco análoga à constituição do meu gênio, era preciso que desamparasse inteiramente os estudos filosóficos para me ir perder nos profundos abismos das minúcias e formulários das intrigas forenses. O que demandava muitas aplicações e prática de negócios deste gênero, que faziam incompatíveis meditações sobre coisas de outro porte. ${ }^{41}$
\end{abstract}

Como explica Manoel Luiz Salgado Guimarães, referindo-se aos relatos de viagem publicados no periódico $O$ Patriota já na segunda década do século XIX, o conhecimento do mundo natural englobava diferentes aspectos, não apenas físicos e climáticos, mas também um inventário cuidadoso dos aspectos humanos e sociais observados nas localidades em estudo:

do animal, recomendar-se-á aos correspondentes que mandem junto com elas um desenho ou uma descrição exata ao menos daqueles que não são vulgarmente conhecidos ou que têm alguma coisa de extraordinário". Ibid., p. 45.

${ }^{41}$ LISBOA, op. cit., p. 495. 
Descrever uma viagem científica a uma das possessões do Império colonial português supunha não apenas conhecer suas particularidades naturais (a flora, a fauna, o clima e a natureza do solo), mas também seus habitantes, seus usos, costumes, formas de organização social, implicando questões envolvendo a historicidade dessas mesmas populações. ${ }^{42}$

O autor das Reflexões sobre a História Natural do Brasil publicadas em 1819 , por sua vez, recomendava que os correspondentes juntassem às notícias geográficas da localidade em estudo, todas as informações que pudessem alcançar relativas à moral dos habitantes daquele lugar: "E para observarem nesta relação a ordem que em tudo é necessária, poderão reduzir todas as notícias que examinarem a títulos diversos, preferindo sempre a divisão mais natural: religião, política, economia, artes, tradições, etc." ${ }^{43} \mathrm{O}$ autor enumera os aspectos que considerava importantes de ser observados em cada um desses títulos:

Em quanto às Artes, mostrarão $1^{\circ}$ o estado da sua agricultura, os usos e defeitos de seus instrumentos de lavoura; $2^{\circ}$ o modo de fazerem as suas caças e pescas; $3^{\circ}$ as plantas de que se servem para sustento, vestido, remédios, tintas, etc.; $4^{\circ}$ os animais que empregam no trabalho e em outros serviços domésticos; $5^{\circ}$ os minerais que extraem da terra, os usos a que os aplicam e o modo de os reduzir a esses mesmos usos; $6^{\circ}$ a perfeição ou imperfeição das artes, manufaturas e de todo o gênero de indústria e comércio que houver no país. ${ }^{44}$

A tarefa era grande e talvez por isso Silva Lisboa não se sentisse capaz de realizá-la naquele momento, devido ao seu forçado afastamento do meio acadêmico, uma vez que procurava ganhar a vida como advogado, como ele afirmava na sua carta. ${ }^{45} \mathrm{Ou}$ talvez a falsa modéstia fosse um artifício para conseguir, através da sua relação com o naturalista italiano, alguma colocação na burocracia estatal do Império Português. ${ }^{46}$ Importante ressaltar que mesmo durante o período que atuou como ouvidor ou que esteve ligado ao ensino régio,

\footnotetext{
${ }^{42}$ GUIMARÃES, op. cit., p. 86.

${ }^{43}$ Instrução para os viajantes e empregados nas colônias sobre a maneira de colher, conservar e remeter os objetos de História Natural. op. cit., p. XVII.

${ }^{44}$ Ibid., p. XVIII.

${ }^{45}$ Como informa Tereza Cristina Kirschner, em janeiro de 1780, Silva Lisboa foi indicado pelo governador da capitania da Bahia para o cargo de ouvidor da comarca de Ilhéus, que não exerceu nem durante um ano completo devido aos incidentes que teve com a população local no seu empenho de fazer cumprir a legislação produzida no reino. KIRSCHNER, op. cit., p. 45 a 60.

${ }^{46}$ Se essa era a intenção, o artifício deve ter dado resultado, pois logo no ano seguinte (1782) Silva Lisboa é nomeado por D. Maria I professor de Filosofia Racional e Moral na cidade de Salvador, cargo que exerceu até 1797. Alguns meses depois, Lisboa foi nomeado também para o cargo de professor substituto de língua grega na mesma cidade. Cargo que ocupou até 1787.
} 
Silva Lisboa continuou dedicando-se às pesquisas em História Natural. ${ }^{47}$ Assim sendo, ele não deve ter encontrado a dificuldade mencionada para satisfazer a solicitação do seu antigo mestre em Coimbra. Na alentada correspondência, ele descreve com detalhes as características geográficas da Baía de Todos os Santos, com a localização das suas ilhas e regime de ventos e marés, ressaltando o seu potencial econômico:

Uma barra espaçosíssima, capaz de receber ao mesmo tempo e sem perigo as frotas as mais numerosas, um ancoradouro profundo, seguro e abrigado, defendido por uma fortaleza respeitável no meio das águas edificada, constitui sem disputa, esta cidade, um dos mais belos portos do universo e lhe dá uma natural vantagem para o fazer um dos mais ricos empórios do planeta. ${ }^{48}$

Lisboa descreve também o aspecto físico da cidade de Salvador, sua implantação, seu clima e a sua influência sobre a constituição da população. Detém-se na descrição da posição e situação das fortificações que guarneciam essa baía e a cidade, com as suas respectivas tropas. O que ele considera "um dos artigos mais importantes da descrição de um país”, juntamente com seu governo político e econômico e a sua opulência. ${ }^{49}$ Após a descrição das fortalezas, Silva Lisboa passa à descrição das tropas regulares e de milícias existentes na cidade, informando que havia três regimentos de tropas de linha de 700 homens cada um, dois regimentos de crioulos e mulatos forros, dois regimentos de milícias e mais dois regimentos conhecidos como Regimento da Nobreza e Familiares do Santo Ofício. ${ }^{50}$

Porém, o assunto ao qual o autor dedica mais atenção na sua carta é a descrição da situação da agricultura, das manufaturas e do comércio na cidade, nas ilhas e no recôncavo, com vistas a dar uma ideia do potencial econômico da capitania: “como a opulência pública está na razão composta da extensão da agricultura, variedade e perfeição das artes, vastidão do comércio, eu irei notando sucessivamente cada coisa de per si para dar idéia da riqueza da Bahia" ${ }^{51}$ Com relação à agricultura, Lisboa presta especial atenção para a cultura do açúcar.

\footnotetext{
${ }^{47}$ Devido aos seus conhecimentos nessa área, foi designado pelo governador da capitania da Bahia a realizar uma pesquisa nas proximidades da vila de Cachoeira, em 1782, onde havia sido encontrada uma porção de cobre, onde pode também realizar observações sobre a cultura do tabaco. Era também constantemente procurado para identificar ervas nativas da região. KIRSCHNER, op. cit., p. 68 a 71.

${ }^{48}$ LISBOA, op. cit., p. 495.

${ }^{49}$ Ibid., p. 497.

${ }^{50}$ Ibid., p. 498.

${ }^{51}$ Ibid., p. 498.
} 
Seguindo o espírito pragmático da Ilustração portuguesa, o autor descreve em detalhes o processo produtivo da cana e chama a atenção para os seus aspectos econômicos:

O açúcar não tem todo o mesmo valor: distinguem-se 3 preços diferentes de 9 tostões até 14, segundo as 3 qualidades de mascavado, redondo e fino. Os ditos preços são taxados pela Inspeção para se não poder vender por menos, afim de sustentar o valor do gênero. Porém, sempre por estilo da praça, ainda em tempo ordinário, por convenção das partes e dos mesmos negociantes, sempre se vende com mais um ou 2 tostões sobre o ferro da Inspeção. Tomando-se um preço médio de 10 tostões a cada arroba vem a render cada tarefa de 30 braças quadradas pelo menos 48:000 rs. Acrescentando-se a este valor o preço dos melaços que se não condensaram, que custam uma quinta parte do valor do açúcar, isto é, acrescentando-se 9.000 e tantos réis, quinto de $48 \$$, fica o rendimento da dita tarefa importando $57 \$ 000$ rs. Se o proprietário for ecônomo, que tenha o seu alambique e o trem necessário para o mel destilar aguardente, o que lhe procura um benefício sem dúvida de mais $15 \%$, ainda mais aumentará o valor do dito terreno relativo ao seu rendimento. ${ }^{52}$

No cálculo do potencial econômico da produção do açúcar não podia deixar de ser levado em conta um elemento importante, ao qual o autor dedica atenção, a utilização da mão-de-obra escrava:

Um proprietário que tem 50 escravos de trabalho constante e regular pode ter sem dificuldade 100 tarefas de cana que, segundo o cálculo feito, podem render 5:700\$000 rs. Verdade é que este rendimento não é líquido e que dele se deveria deduzir o valor da sustentação dos escravos, doenças, mortes, vestidos, restabelecimento da fábrica, salários de feitores que administram a lavoura, mestre de açúcar, caixeiros de engenho, etc. ${ }^{53}$

Silva Lisboa tece observações também a respeito da cultura do tabaco, o segundo ramo da agricultura considerado por ele o mais importante da capitania da Bahia, além da mandioca e do algodão. Porém, suas observações a esse respeito são muito mais sucintas e não atingem, nem de longe, o grau de detalhamento dispensado pelo autor para a cultura da cana. $\mathrm{O}$ autor se justifica afirmando, a respeito da cultura do tabaco, que prescindia de "expor o curso desta

\footnotetext{
${ }^{52}$ Ibid., p. 500.

${ }^{53}$ Ibid., p. 500. A respeito do tratamento que deveria ser dispensado aos escravos para não se prejudicar a produção do engenho, Silva Lisboa faz interessantes observações a favor de um tratamento menos rude por parte dos proprietários: "Todos os dias se recebem más notícias de um preto morto, outro doente, outro fugitivo, outro rebelde, outro que deixou corromper os pés de bichos por preguiça e ainda para desgostar o seu senhor. Contudo, eu atribuo grande parte destes danos ao abuso violento que se faz da liberdade dos escravos, do quais uma boa parte perece às mãos da fome, da miséria, da desesperação e dos atrozes castigos que se lhes inflige. Os senhores moderados, mas não inertes, costumam pelo ordinário ter melhores negros e mais duráveis. E, para dizer a verdade, os escravos são mui sensíveis às demonstrações de benignidade de seus senhores. As suas almas com pouco se contentam e conduzidas com generosidade não são atrozes, como ordinariamente se crê". Ibid., p. 502.
} 
lavoura e a manobra com que se prepara o tabaco por diminuir a extensão desta carta e porque isso vem descrito em livros que tratam da cultura da América". 54

No final da sua carta, Silva Lisboa reserva ainda algumas páginas para observações com relação às indústrias existentes na capitania e ao seu comércio interno e, principalmente, exterior, contrastando a escassez das primeiras com a vivacidade do segundo. Com relação ao comércio, merece especial destaque na narrativa de Silva Lisboa o comércio com a costa da África. Ou seja, o tráfico de escravos, feito em troca do tabaco e da cachaça produzidos na capitania:

O comércio para a África é de grande conseqüência para esta praça: é dirigido para o que se denomina resgate de escravos. Porém, não é esse o benefício desta negociação, como logo direi. A base dela é o tabaco, ordinariamente de refugo ou da segunda folha e aguardentes do país. A Bahia expede todos os anos mais de 50 embarcações entre corvetas e sumacas. 8 ou 10 corvetas vão para Angola, para onde também levam muita fazenda da Europa. As demais vão correr a Costa da Guiné a comprar escravos. ${ }^{55}$

A atenção dispensada por Lisboa à agricultura, principalmente a cultura da cana, que constitui o cerne da sua descrição da Bahia, expressava já algumas das suas concepções sobre Economia Política, que ele desenvolveria em estudos posteriores, onde defende que o comércio e, principalmente, a agricultura deveriam ser as principais atividades econômicas da colônia portuguesa da América. ${ }^{56}$

Se, durante o reinado de D. José I, o absolutismo ilustrado teve seus primeiros impulsos no que se refere à questão da apreensão do conhecimento pela elite da sociedade portuguesa, sua aplicação prática na administração, principalmente no que se refere ao mundo colonial, ocorreu no reinado de D. Maria I. Como afirma Ana Rosa Cloclet, a partir do reinado mariano se assistiu um desenfreado interesse por tudo que provinha da exótica natureza ultramarina: "uma obsessão por identificar, nomear e classificar seus produtos e materiais,

\footnotetext{
${ }^{54}$ Ibid., p. 503.

${ }^{55}$ Ibid., p. 504. Nesse ponto, Silva Lisboa tece argutas observações sobre o impacto da escravidão na sociedade baiana: "A cidade da Bahia tem quase 50.000 [pessoas], de que só a quarta parte será composta de brancos. Esta população não se aumenta porque o número de casamentos é muito diminuto. A dos escravos é impraticável e contra a decência das famílias. Porém os senhores toleram facilmente o comércio ilegítimo pelo fruto do aumento dos escravos que disso lhe resulta. A maior parte é bem inútil ao público e só destinada para servir aos caprichos e voluptuosas satisfações de seus senhores. É prova de mendicidade extrema o não ter um escravo. (...) É indispensável ter ao menos 2 negros para carregarem uma cadeira ricamente ornada, um criado para acompanhar este trem. Quem saísse à rua sem esta corte de africanos está seguro de passar por um homem abjeto e de economia sórdida". Ibid., p. 505

${ }^{56}$ Ideias que serão abordadas com mais detalhamento no próximo capítulo.
} 
como se a informação mais precisa fosse a condição da reforma mais eficiente". ${ }^{57}$ Dessa forma, assiste-se ao aprofundamento do processo de reformas educacionais e científicas em Portugal durante o reinado de D. Maria I (1777-1798) e a regência de D. João (1799-1818).

Em dezembro de 1779, foi criada Academia Real das Ciências de Lisboa a partir do projeto de Domenico Vandelli de criação de uma congregação geral das ciências, e dos esforços de articulação política de D. João de Bragança (17191806), $2^{\circ}$ Duque de Lafões, e do abade José Correia da Serra (1750-1823). ${ }^{58} \mathrm{O}$ medo de disseminação dos abomináveis princípios franceses fez com que a força repressiva da polícia do Intendente Diogo Inácio de Pina Manique (1733-1805) recaísse sobre os espaços de sociabilidade cultural e as atividades acadêmicas. A Universidade de Coimbra e a própria Academia das Ciências não escapavam da vigilância de Pina Manique, que considerava essa última "um antro de revolucionários, que formavam uma rede perigosa". 59 Ainda mais porque alguns de seus principais membros, como o Duque de Lafões, o abade Correia da Serra e Vandelli, eram reconhecidos como maçons. O que leva Luiz Carlos Villalta a considerar a Academia uma organização paramaçônica. ${ }^{60}$

Porém, como ressalta Diogo Ramada Curto, "se em relação à Academia o governo pela mão do Intendente Geral pouco podia intervir, dada a cadeia de proteções que culminavam na figura do duque de Lafões, já o mesmo não acontecia quanto à Universidade". ${ }^{61}$ Como explica o autor, a partir de 1799, quando D. Francisco de Lemos reassume a reitoria da Universidade, instaura-se uma verdadeira vigilância sobre o comportamento dos estudantes. Lemos solicitava para si a prerrogativa de poder visitar as casas dos livreiros e dos

\footnotetext{
${ }_{58}^{57}$ SILVA, A. R. C. da. op. cit., p. 152.

58 José Luís Cardoso, no já citado parágrafo em que critica a ideia que responsabiliza exclusivamente os estrangeirados pela introdução das Luzes em Portugal, analisa a influência de Lafões e Correia da Serra na criação da Academia de Ciências (CARDOSO, op. cit., p. 44 a 50).

${ }^{59}$ CURTO, D. R. D. Rodrigo de Souza Coutinho e a Casa Literária do Arco do Cego, p. 36.

${ }^{60}$ Como explica esse autor, a maçonaria fez-se presente em Portugal desde 1727, ano em que o católico inglês Willian Dugood fundou em Lisboa uma primeira oficina. Na segunda metade do século XVIII, o misticismo, o ocultismo, o deísmo, o filosofismo e o liberalismo infiltraram-se nas lojas maçônicas e conquistaram a hegemonia. A partir de então, a maçonaria agiu como foco de veiculação de ideias do Iluminismo e Liberalismo. Por isso, havia a associação, em Portugal, entre pedreiros-livres e jacobinos; e o temor de que o incêndio revolucionário se espalhasse por Portugal fez com que a perseguição às lojas portuguesas se acirrasse durante o reinado de D. Maria. (VILlaLTA, L. C. Libertinagens e livros libertinos no mundo luso-brasileiro (17401802), p. 539/545). Além disso, Lafões acolhia em sua casa o naturalista francês refugiado em Portugal Pierre Marie Auguste Broussonet (1761-1807).

${ }^{61}$ CURTO, op. cit., p. 36.
} 
estudantes quando bem lhe parecesse: "Procurava-se a todo custo vigiar e punir a vida licenciosa dos estudantes (...) e, ao mesmo tempo, fomentar neles o gosto pelo catecismo. O espírito da reforma pombalina dava, assim, lugar à perseguição e à censura". ${ }^{2}$ Tereza Cristina Kirschner também alude ao retrocesso na Universidade de Coimbra pós-pombal, afirmando que após a queda daquele ministro

pouco a pouco, a universidade perdeu o fôlego inovador e a decadência da instituição tornou-se notória. A rotina que se instalou em Coimbra refletiu-se nos métodos de ensino e as 'aulas ditadas' voltaram a ser ministradas pelos professores. A partir de 1779 o ensino de filosofia ficou a cargo das congregações religiosas, o que indica a reconquista de um espaço no sistema de ensino por parte da Igreja. ${ }^{63}$

Reconquista de espaço que ocorreu não apenas no sistema de ensino. Por decreto de 21 de junho de 1787, D. Maria I substitui a Real Mesa Censória de Pombal pela Comissão Geral para o Exame e a Censura dos Livros. Ato interpretado por Luiz Carlos Villalta como um recuo no ímpeto secularizador e regalista de Pombal. O que, segundo alguns autores, marcaria o caráter da denominada Viradeira, como ficou conhecida a passagem da governação pombalina ao reinado mariano:

A rainha reconheceu a autoridade pontifícia no assunto, ao mesmo tempo em que se proclamou autorizada pelo Papa a criar o novo tribunal censório. Determinou que o presidente do tribunal teria que ser necessariamente um clérigo e, além disso, restabeleceu a legitimidade da censura eclesiástica nas matérias religiosas. ${ }^{64}$

Refletindo sobre o conceito de Viradeira, porém, Fernando Novais ressalta que a criação da Academia Real das Ciências indica ao invés de um movimento de repúdio aos quadros da administração pombalina, um nexo de continuidade do ponto de vista da ação do Estado:

O período que se segue ao consulado pombalino aparece-nos muito mais como seu desdobramento que sua negação (...) a chamada viradeira tem muito reduzida a sua importância efetiva; houve sim uma viragem significativa, mas no sentido de uma maior integração nas linhas do reformismo ilustrado. Foi, efetivamente, no período de D. Maria I e do Príncipe Regente Dom João que Portugal se abriu mais largamente aos influxos da Ilustração européia. A Academia Real de Ciências foi

\footnotetext{
${ }^{62}$ Ibid., p. 37/38.

${ }^{63}$ KIRSCHNER, op. cit., p. 34.

${ }^{64}$ VILLALTA, L. C. Censura literária e inventividade dos leitores no Brasil colonial, p. 60.
} 
por excelência o centro de assimilação dessas novas correntes, e de sua adequação à realidade portuguesa. ${ }^{65}$

A Academia deu impulso a um memorialismo científico sobre os mais diversos temas, consolidado nas suas Memórias Econômicas para o adiantamento da agricultura, das artes e da indústria em Portugal e suas conquistas, publicadas em 5 tomos entre 1789 e 1815. Sua missão era a de converter os estudos e os produtos das viagens dos ilustrados portugueses em retornos imediatos para o Império. Tais trabalhos pretendiam contribuir para a elaboração de um programa de governo com propostas claras de diversificação e incremento da agricultura, emprego de novas técnicas, de exploração e produção de minérios e, sobretudo, sugestões de formas eficientes para preservação do comércio colonial. Como chama a atenção Maria de Lourdes Viana Lyra

Ao instituir a Academia Real das Ciências como fórum de debates das proposições de ordem prática, em direção ao desenvolvimento do Estado, o governo ampliava a esfera de participação aos ilustrados, a maioria formada em Coimbra, arregimentado-os no esforço conjunto de repensar a nação e traçar novas diretrizes políticas para assegurar a existência do Reino e da Monarquia e promover o desenvolvimento do império português. ${ }^{66}$

D. Rodrigo de Sousa Coutinho (1755-1812) foi talvez a expressão mais nítida da nova mentalidade ilustrada após a queda de Pombal, de quem era discípulo e afilhado. Ex-estudante do Colégio dos Nobres e da Universidade de Coimbra, ${ }^{67}$ onde se matriculou no curso jurídico em 1773, sua primeira e mais longa função administrativa foi a nomeação para embaixador em Turim como

\footnotetext{
${ }^{65}$ NOVAIS, op. cit., p. 224. Oswaldo Munteal chama a atenção para o fato de que a Academia abrigou grande número de simpatizantes e mesmo ministros e professores nomeados à época de Pombal (MUNTEAL FILHO, op. cit., p.187/188). Nívia Pombo Cirne dos Santos, por sua vez, afirma que não se deve compreender o período sem antes retomar as principais linhas de continuidades, que numa primeira instância ficou assegurada pela manutenção de elementos políticos nos principais cargos administrativos do reino. (SANTOS, N. P. C. dos. Dom Rodrigo de Sousa Coutinho: Pensamento e ação político-administrativa no Império português (1778-1812). p. 35/36). Enquanto Ana Rosa Cloclet da Silva ressalta que, apesar de assistir-se no reinado mariano a uma reabilitação da nobreza alijada do poder por Pombal, é preciso lembrar que os interesses consolidados pelos principais empreendimentos pombalinos estavam por demais arraigados na sociedade lusa para serem simplesmente descartados ou substituídos. (SILVA, A. R. C. da, op. cit., p. 106/107).

${ }^{66}$ LYRA, op. cit., p. 42.

${ }^{67}$ O Real Colégio dos Nobres de Lisboa fez parte do conjunto de reformas educacionais do Marquês de Pombal, tendo sido restabelecido pela Carta Régia de 7 de março de 1761, como uma escola para a educação da nobreza e da fidalguia. Expressava a intenção de se formar uma nova nobreza, mais adequada a compor os quadros burocráticos do Estado português. A esse respeito ver: FALCON, F. J. C. A Época Pombalina, p. 440/441; SILVA, A. R. C. da. op. cit., p. 69/70. E, para uma visão mais detalhada do funcionamento do Real Colégio dos Nobres ver SANTOS, op. cit., p. 127 a 129.
} 
Ministro Plenipotenciário da Coroa portuguesa junto ao reino da Sardenha (entre 1778 e 1796). ${ }^{68}$ Durante estes anos passou também por Madri, Paris e Suíça. Experiência que completou a sua formação intelectual, fazendo dele um estrangeirado. Escreveu algumas memórias econômicas sobre as vantagens do comércio com a Itália, os métodos de produção da seda, a utilização das minas no Brasil e outros tópicos concernentes à política econômica do mercantilismo ilustrado. ${ }^{69}$ Nas palavras de Ana Rosa Cloclet, D. Rodrigo representou "a síntese do estadista intelectualizado exigido pela modernização portuguesa" ${ }^{70}$

Segundo Nívia Pombo Cirne dos Santos, foi durante a sua missão diplomática em Turim que foram produzidas as suas principais propostas de reorganização da sociedade portuguesa, que marcaram a sua ação administrativa posterior como Secretário de Estado da Marinha e Domínios Ultramarinos (17961801), Presidente do Real Erário (1801-1803) e Secretário de Estado dos Negócios Estrangeiros e da Guerra (1808-1812). ${ }^{71}$ Nos seus projetos de reforma, a preocupação com o fomento da produção e exploração das colônias era representativa da sua consciência da fragilidade do Reino e da sua dependência econômica e política em relação à sua principal colônia. ${ }^{72}$ Ressalta Nívia que enquanto Ministro da Marinha e Ultramar, tal preocupação estava necessariamente embutida nas suas atribuições. Porém, desde quando ainda atuava como diplomata em Milão, D. Rodrigo passou a ser uma espécie de coordenador das atividades científicas nas colônias, sendo um grande entusiasta das expedições científicas ao ultramar. ${ }^{73}$

\footnotetext{
${ }^{68}$ Sua formação política, porém, segundo reflexão de Nívia Pombo Cirne dos Santos, era tributária de uma linha de pensamento filosófico-ilustrada que havia se iniciado anteriormente às reformas do ensino. Seu pensamento secularizado partia não apenas do fato de ter estudado no Colégio Real dos Nobres de Lisboa e na Universidade de Coimbra reformada, mas das continuidades de uma abertura cultural onde estas instituições já representavam a culminância de um longo processo. (SANTOS, op. cit., p. 260)

${ }^{69}$ Reflexões politicas sobre os meios de criar e fundar solidamente em Portugal a cultura e manufatura da seda (1784), Memória sobre a verdadeira influência das Minas de metais preciosos na indústria das nações que as possuem e especialmente da Portuguesa (1790) e o Discurso sobre o comércio da Itália relativamente ao de Portugal (1796).

${ }^{70}$ SILVA, A. R. C. da. op. cit., p. 118.

${ }^{71}$ SANTOS, op. cit., p. 131 a 134.

${ }^{72}$ Como explica Tereza Cristina Kirschner: "A importância do Brasil para a economia portuguesa no período é visível na relevância que ocupavam as reexportações dos produtos da colônia no comércio externo português. Entre 1796 e 1807 elas representavam 64,4\% do conjunto das exportações, contra apenas $29 \%$ dos produtos da metrópole". KIRSCHNER, op. cit., p. 96.

${ }^{73}$ Para uma descrição detalhada das principais expedições científicas enviadas ao Ultramar e o envio de produtos de História Natural sob a supervisão de D. Rodrigo de Souza Coutinho, durante o reinado de D. Maria I e a regência de D. João, ver MUNTEAL FILHO, op. cit., p. 155 a 172. Oswaldo Munteal ressalta o fato de que Souza Coutinho dava continuidade à política de seu
} 
Em 1798, Sousa Coutinho apresentou ao Conselho de Ministros de Portugal a sua Memória sobre o melhoramento dos domínios de Sua Majestade na América, um verdadeiro programa de reformas para a administração do Império onde sobressai a consciência de que o reerguimento do Império Português dependia não apenas da manutenção e exploração racional da sua principal colônia, mas principalmente do reforço da ideia da existência de uma comunidade de interesses entre as duas partes do Império Português. Dessa forma, o desenvolvimento da Metrópole passava a ser concebido conjunta e articuladamente ao da sua principal colônia. Revertendo a lógica do processo histórico de dominação colonial, D. Rodrigo utilizou-se de tais argumentações para construir a imagem de uma união natural existente entre os interesses coloniais e os metropolitanos. Como explica Maria de Lourdes Viana Lyra:

Preservar a unidade do mundo português consistia o projeto político embutido no programa de reformas, cuja mira era a formação de um grande Estado atlântico - um novo e promissor império lusitano ou, como diz a historiografia atual, um império luso-brasileiro. ${ }^{74}$

No novo império português proposto por D. Rodrigo, Portugal aparecia não mais como o centro monopolizador das relações comerciais, mas como pólo dinamizador dessas relações. O projeto de reformas ilustradas do ministro naturalizava a posição central da velha metrópole dentro do Império, interpretada como uma superioridade natural advinda da sua posição central no comércio europeu. ${ }^{75}$ Mas, sobretudo, deveria prevalecer o sentimento de pertencimento à nação lusa, que teria a função de fortalecer a unidade do império e de assegurar a criação de um sentimento de identidade entre os habitantes das suas diferentes partes constitutivas, que deveriam ser consideradas como províncias da monarquia e não mais como colônias. Ele buscava naturalizar a ideia da

predecessor no Ministério, Martinho de Melo e Castro (1770-1795): "Tanto Melo e Castro quanto Souza Coutinho orientaram suas ações para o aproveitamento dos recursos naturais dos territórios portugueses. De acordo com essa orientação era essencial investir cada vez mais nas viagens filosóficas" (MUNTEAL FILHO, op. cit., p. 160).

${ }^{74}$ LYRA, op. cit., p. 69.

${ }^{75}$ Fernando A. Novais afirma sobre esse discurso que: "a pequenez e fraqueza da metrópole, aliada à sua posição na encruzilhada das rotas, torna 'natural' o que tinha sido produto da história, isto é, a vinculação de Portugal com suas colônias" (NOVAIS, op. cit., p. 234). Como ressaltou esse autor, o discurso baseado na necessidade de reforço dos nexos coloniais se constrói no momento mesmo em que esses nexos começam a ser ameaçados por atitudes de contestação da parte dos colonos americanos, naquela que o autor denominou de a fase crítica do final do Antigo Regime. Logo, esse projeto de desenvolvimento integrado visava uma interdependência que preservasse o sistema. 
interdependência, da reciprocidade nas relações entre a metrópole e suas conquistas e da necessidade da preservação e reforço da sua unidade política. Maria de Lourdes Vianna Lyra sintetiza a ideia geral do programa de reformas de Sousa Coutinho:

Sousa Coutinho mostrava-se consciente de que, realçando pseudo-relações interdependentes e recíprocas, estaria revelando aos portugueses 'nascidos nas quatro partes do mundo' o quanto eram comuns os seus interesses e, portanto, o quanto deveriam ser comuns os seus propósitos, desde que tinham a fortuna de pertencer à civilizada nação portuguesa. Os interesses comuns cimentariam a unidade política das partes integrantes do todo com sede na Europa, o que, além de prevenir e afastar o perigo de movimentos de independência, fortaleceria a nação portuguesa. ${ }^{76}$

Segundo Nívia Pombo Cirne dos Santos, essa memória inscreveu seu autor na discussão sobre o papel das colônias para o mundo europeu, expressando as suas reflexões sobre uma via de modernização do Antigo Regime português que considerasse o fato de se ter e manter colônias. D. Rodrigo defende, nessa memória, a importância da manutenção de dois princípios políticos que assegurassem a soberania da monarquia portuguesa: a unidade política e o preceito da dependência econômica:

A junção destes dois princípios políticos demonstra a importância da exploração colonial como fator indispensável para o reerguimento do comércio e da indústria em Portugal, assim como uma estratégia que buscava uma unificação de interesses em benefício de um centro que organizaria e determinaria diretrizes políticas. ${ }^{77}$

Após assumir o posto de Ministro da Marinha e Ultramar, ele empregou o conhecimento de bacharéis naturais do Brasil e formados na Universidade de Coimbra a serviço do desenvolvimento científico e econômico do Império. Esses homens compunham aquilo que Kenneth Maxwell denominou de a Geração de 1790, uma verdadeira força-tarefa, nas palavras do autor, incumbida de fornecer informações práticas para a Coroa portuguesa. Segundo a reflexão Maxwell, a participação destes letrados na administração colonial auxiliando na elaboração de políticas capazes de aumentar os vínculos entre colônia e metrópole promovia a "acomodação" de interesses e compromissos entre Portugal e sua principal

\footnotetext{
${ }^{76}$ LYRA, op. cit., p. 72. Um resumo das ideias de Sousa Coutinho se encontra nos artigos de Kenneth Maxwell, Condicionalismos da independência do Brasil (p. 378/379) e A geração de 1790 e a idéia do império luso-brasleiro (p. 184/185). Enquanto Maria de Lourdes Vianna Lyra faz uma análise mais detalhada do programa de reformas do Ministro (LYRA, op. cit., p. 66 a 83).

${ }^{77}$ SANTOS op. cit., p. 198/199.
} 
colônia, reduzindo os anseios e reivindicações de inserção nos cargos administrativos designados pelo poder régio:

Essa colaboração entre os intelectuais brasileiros e os ministros esclarecidos produziu uma ideia imperial, de inspiração luso-brasileira, que foi além do nacionalismo, em direção a uma solução mais ampla, de caráter imperial, tentando desarmar as tensões Metrópole-Colônia. ${ }^{78}$

Para Nívia Pombo Cirne dos Santos, arregimentação de colaboradores entre os letrados naturais da colônia por D. Rodrigo, para o seu projeto de reformas ilustradas, representava a dificuldade que o ministro tinha em encontrar apoio entre os membros da corte portuguesa. Segundo a autora:

Dom Rodrigo de Sousa Coutinho, enquanto Ministro da Marinha e Domínios Ultramarinos foi capaz de perceber com argúcia a linha tênue do pensamento ilustrado que separava reformismo de revolução. Neste sentido, trabalhou para tentar apaziguar as diferenças e distinções com que os súditos do reino e ultramar eram tratados, cuidando para que ocupassem funções que estavam aptos para assumir, a partir do critério das Luzes. ${ }^{79}$

Além de Silva Lisboa, podem ser citados como componentes desse grupo, pelo menos, mais dois nomes que adquirem grande expressão política e cultural durante o reinado de D. João e o processo de independência da colônia: José Bonifácio de Andrada e Silva (1763-1838) e Hipólito José da Costa Pereira Furtado de Mendonça (1774-1823). José Bonifácio era formado pela Universidade de Coimbra em Filosofia e Leis e foi enviado em 1790 pelo, então, Ministro dos Negócios Estrangeiros e da Guerra, Luís Pinto de Sousa Coutinho, à Paris, centro da agitação social e política da Europa, juntamente com Manuel Ferreira da Câmara Bethencourt (1762-1835), bacharel em Cânones pela mesma Universidade, para tirar cursos de Física e Mineralogia. Posteriormente, dirigiu-se à Alemanha, passando ainda pela Boêmia, pela Hungria, pela Áustria e pela Itália.

\footnotetext{
${ }^{78}$ MAXWELL, K. A geração de 1790 e a idéia do império luso-brasileiro, p. 190. Segundo Maxwell, o período compreendido entre 1796 e 1808, marcado pelo fracasso do movimento oligárquico de Minas Gerais, em 1789, e a ameaça vinda de baixo, posta a descoberto pelos artesãos da Bahia, em 1798, no plano interno; e pelos desdobramentos da Revolução Francesa e da Revolução de Independência do Haiti, no plano externo; marcou um momento de inflexão nas ideias dos ilustrados ultramarinos que, até então, haviam falado ingenuamente sobre república e revolta. A opção pela reforma se tornava, assim, uma forma de evitar a revolução.

${ }^{79}$ SANTOS, op. cit., p. 229. Nívia Pombo ressalta também as ligações familiares de D. Rodrigo com o Brasil como possível explicação para a formação de uma rede clientelar composta por letrados nascidos na colônia: "É de grande relevância ressaltar as raízes de d. Rodrigo de Sousa Coutinho no Brasil; talvez elas possam explicar a formação de uma rede clientelar, especialmente ligada aos intelectuais mineiros no período que esteve à frente da Secretaria da Marinha e Domínios Ultramarinos". SANTOS, op. cit., p. 15.
} 
Sua primeira memória, datada do mesmo ano de 1790, abordava o aperfeiçoamento da caça da baleia e extração do seu óleo. ${ }^{80}$ Essa viagem de instrução pela Europa durou 8 anos e, segundo Nívia Pombo Cirne dos Santos, possivelmente contou também com o incentivo de D. Rodrigo de Sousa Coutinho, sendo exemplar da sua preocupação com o bom aproveitamento das riquezas minerais existentes no Império Ultramarino Português. ${ }^{81}$

Hipólito da Costa, formado pela Universidade de Coimbra em Leis, Filosofia e Matemática, recebeu de D. Rodrigo, em 1798, o encargo de estudar nos Estados Unidos e no México os métodos de cultivo do cânhamo, do tabaco, do algodão, da cana, do índigo, do arroz e da cochonilha, para a sua aplicação no Brasil. Segundo Sérgio Goes de Paula, por dificuldades de transporte, de comunicação e por estorvos do governo espanhol, que lhe proibiu a entrada no México, a viagem foi baldada quanto aos seus propósitos oficiais, "morrendo de frio os espécimes animais e vegetais obtidos, salvando-se apenas alguns caixotes remetidos a Lisboa no começo da viagem". ${ }^{82}$ Tendo regressado a Lisboa em fins de 1800, foi nomeado Diretor Literário da Impressão Régia de Lisboa. Nesse mesmo ano ou no seguinte foi enviado a Londres por D. Rodrigo para comprar livros para a Biblioteca Pública e máquinas para a tipografia. ${ }^{83}$

Essas peregrinações científicas de letrados do Reino em direção às colônias ou de letrados das colônias para outras partes de dentro ou de fora do Império

\footnotetext{
${ }^{80}$ SILVA, J. B. de A. e. Memória sobre a pesca da baleia e extractos do seu azeite; com algumas reflexões a respeito das nossas pescarias. In: Memórias Econômicas da Academia Real de Ciências de Lisboa. MDCCXC (1790), t. II, p. 388. Reeditada em CALDEIRA, J. José Bonifácio de Andrada e Silva. p. 51 a 56. A respeito do pensamento e atuação de José Bonifácio na ilustração portuguesa e no processo de construção da nação independente ver: DIAS, op. cit., p. 108; ARAÚJO, op. cit., p. 45 a 118 ou SILVA, A. R. C. da, op. cit., p. 337 a 411.

${ }^{81}$ Expressa na sua Memória sobre a verdadeira influência das Minas de metais preciosos na indústria das nações que as possuem e especialmente da Portuguesa, apresentada à Academia Real das Ciências de Lisboa em 1789. Como explica a autora, nesse escrito D. Rodrigo pretendeu refutar autores como Montesquieu, que consideravam a mineração a causa da decadência de Estados exploradores de colônias como Portugal. (SANTOS, op. cit., p. 190/191)

${ }^{82}$ PAULA, S. G. de (org.). Hipólito José da Costa. p. 13; LUSTOSA, I. A pátria de Hipólito, p. xlvi.

${ }^{83}$ Kenneth Maxwell inclui ainda nesse grupo nomes como os de Antônio Pires da Silva Ponte e José Vieira Couto (MAXWELL, K. A geração de 1790 e a idéia do império luso-brasleiro, p. 183/184). Pontes e Couto eram ambos, naturais de Minas Gerais, graduados em Matemática e Filosofia em Coimbra. O primeiro escreveu na década de 1790 uma Memória sobre a utilidade pública de se extrair o ouro das minas e os motivos dos poucos interesses que fazem os particulares, que mineram igualmente no Brasil; enquanto o segundo foi incumbido por D. Rodrigo de Sousa Coutinho de investigar os recursos minerais da região das Minas e escreveu, em 1801, uma Memória sobre a capitania de Minas Gerais, seu território, seu clima e produções metálicas (publicada pela Revista do IHGB, volume XI, de 1848) e, em 1803, a Memória sobre as salitreiras naturais de Monte Rorigo; maneira de as auxiliar por meio das artificiais; refinaria do nitrato de potássio ou salitre, reeditada em 1809 pela Impressão Régia do Rio de Janeiro.
} 
português eram também viagens de formação. E completavam-se, em muitos casos, com o engajamento desses naturalistas nos quadros da burocracia do Império, findas as suas comissões. Como explica Ana Rosa Cloclet:

Assim, a orientação teórica, geralmente processada em Coimbra, seguida pelo aprofundamento nos conhecimentos práticos por meio das viagens científicas e o posterior engajamento em cargos-chave da burocracia estatal completava o ciclo da formação dos reformistas luso-brasileiros do final do século, cujo sentido expressava a indissociável articulação entre saber e poder. ${ }^{84}$

Dessa forma, a Universidade de Coimbra e a Academia das Ciências de Lisboa tiveram função importante na formação de letrados e estadistas que acabaram por ter atuação destacada na condução dos assuntos políticos e econômicos durante o governo joanino, em Lisboa e no Rio de Janeiro, atuando em importantes cargos administrativos como foi o caso, por exemplo, do próprio José da Silva Lisboa na direção da Impressão Régia do Rio de Janeiro e no Desembargo do Paço. ${ }^{85}$ A partir das suas posições na burocracia do Império Português, esses homens puderam dar continuidade ao projeto reformista da ilustração portuguesa mesmo após a morte de D. Rodrigo, em 1812. Alguns mantiveram-se nos cargos durante todo o período de permanência de D. João no Rio de Janeiro.

\section{2.}

\section{Sem Impressão não há llustração}

O contato com D. Rodrigo garantiu a Silva Lisboa a nomeação para o cargo de deputado e secretário da Mesa de Inspeção da Agricultura e Comércio da Bahia, que exerceu entre 1798 e 1808. Como explica Tereza Cristina Kirschner, era de responsabilidade das Mesas de Inspeção todas as questões relacionadas ao comércio e agricultura de exportação. ${ }^{86}$ A principal função da Mesa de Inspeção da Bahia, criada em 1751, era controlar a qualidade do açúcar e do tabaco

\footnotetext{
${ }^{84}$ SILVA, A. R. C. da. op. cit., p. 153.

${ }^{85}$ José Bonifácio, por sua vez, ao voltar da sua viagem pela Europa, em 1798 assumiu vários postos na administração do Império português, em atividades ligadas a mineralogia como lente da cátedra de metalurgia na Universidade de Coimbra e Intendente Geral das Minas do Reino.

86 "Com experiência de trabalho prévia na Bahia, conhecedor da sua economia, pesquisador em história natural e inteirado dos assuntos relacionados ao comércio e seguros marítimos, Silva Lisboa correspondia ao ideal de funcionário ilustrado que Sousa Coutinho desejava para atuar na principal colônia portuguesa em áreas de interesse vital para o seu projeto, como a agricultura e o comércio da capitania da Bahia”. KIRSCHNER, op. cit., p. 77.
} 
exportados pela capitania, fiscalizar seus preços e combater o contrabando. Cabialhe também incentivar a produção da capitania, a melhoria das técnicas agrícolas e a introdução de novas espécies vegetais de interesse para o comércio. ${ }^{87}$ Entre as atribuições de Silva Lisboa estava a de realizar freqüentes viagens pelo interior da capitania com o objetivo de observar a situação da produção agrícola, promover melhoramentos nas técnicas de cultivo utilizadas pelos plantadores de cana e tabaco e instruí-los na cultura de novos produtos. Uma das estratégias utilizadas para atingir esse objetivo era a distribuição de exemplares de publicações da recém-criada Oficina Calcográfica, Tipoplástica e Literária do Arco do Cego. ${ }^{88}$

A Casa Literária do Arco do Cego, como ficou mais comumente conhecida, foi fundada em 1799 por D. Rodrigo de Sousa Coutinho, que a colocou sob a direção do botânico natural de Minas Gerais, Frei José Mariano da Conceição Veloso (1742-1811). Naturalista autodidata, Veloso realizou sua formação de botânico na própria colônia em paralelo à formação religiosa. Foi o autor da Flora fluminensis, estudo resultante do trabalho de coleta e descrição realizado entre 1783 e 1790 por encomenda do vice-rei D. Luís de Vasconcelos e Sousa (17791790). Com o fim da gestão de Vasconcelos no Rio de Janeiro, Veloso seguiu com ele para Lisboa, onde passou a participar da Academia das Ciências de Lisboa. Seu contato com D. Rodrigo de Sousa Coutinho data de 1796, quando a Academia negou-lhe o pedido para a publicação de sua Flora $^{89}$ Segundo Nívia Pombo Cirne dos Santos, a ligação de D. Rodrigo e frei Veloso em torno do empreendimento literário do Arco do Cego,

Combinava interesses recíprocos de divulgação de uma temática relacionada à agricultura, à mineração e à flora medicinal da América portuguesa, e de execução de uma política de difusão de uma leitura técnico-científica que tinha como tema uma frase tipicamente ilustrada "Sem livros não há instrução". (...) Acreditavam que a leitura teria o poder de melhorar o futuro dos homens, procurando divulgar algo que ainda estava inacessível para a maioria deles. ${ }^{90}$

As publicações da tipografia visavam à difusão de um determinado modelo

\footnotetext{
${ }^{87}$ Ibid., p. 86.

${ }^{88}$ Ibid., p. 110.

${ }^{89}$ O trabalho, em 11 volumes, foi publicado apenas em 1825-1827, constituindo-se em um importante documento sobre espécimes animais, vegetais e minerais da capitania do Rio de Janeiro, com a reunião, descrição e ilustração de cerca de mil e setecentas espécies. Maria Beatriz Nizza da Silva afirma que a dispersão dos textos e das estampas destinadas à publicação, estando uma parte depositada na Real Biblioteca e outra na Impressão Régia do Rio de Janeiro, contribuiu para a tardia divulgação dos estudos de Frei Veloso (SILVA, M. B. N. da. O botânico Fr. José Mariano da Conceição Veloso e sua expedição na capitania do Rio de Janeiro, p. 204).

${ }^{90}$ SANTOS, op. cit. p. 219/220.
} 
ilustrado de conhecer e intervir na realidade, direcionado especialmente aos domínios da História Natural. Entre as principais tarefas editoriais da tipografia incluíam a compilação dos textos, tradução de obras em língua estrangeira e discussões sobre os temas desenvolvidos. Dentre as publicações do Arco do Cego que Silva Lisboa tinha a função de distribuir entre os agricultores das colônias destacava-se uma dessas compilações organizadas por Frei Veloso: O Fazendeiro do Brasil, melhorado na economia rural dos gêneros já cultivados e de outros que se podem introduzir; e nas fábricas que lhe são próprias, segundo o melhor que se tem escrito a este assunto. Obra em cinco tomos e onze volumes com instruções coligidas de obras estrangeiras para, como informa o título, melhorar a produção de gêneros já cultivados no Brasil (como a cana, o anil, o cacau, o café, o arroz e o cânhamo) e orientar o cultivo de outros gêneros que poderiam ser introduzidos para melhorar a economia na colônia (a canela, o cravo-da-índia, a noz-moscada e a cochonilha). ${ }^{91}$ Ressalta Maria Odila da Silva Dias que os volumes do Fazendeiro do Brasil eram "sistematicamente enviados por D. Rodrigo a fim de serem distribuídos entre os lavradores dos confins do sertão da colônia". 92

Além do Fazendeiro do Brasil, Frei Veloso preparou compilações e traduções sobre os mais variados temas concernentes à História Natural. ${ }^{93}$ Incluindo a tradução de um manual sobre a forma de preparar e conservar os produtos de História Natural, tais como os escritos por Vandelli na década de 1780. A importância do tema para o desenvolvimento da História Natural justificava a constante publicação de manuais. ${ }^{94}$ Como afirma Veloso na

\footnotetext{
${ }^{91}$ VELOSO, J. M. da C. O Fazendeiro do Brasil, melhorado na economia rural dos gêneros já cultivados e de outros que se podem introduzir, nas fábricas que lhe são próprias, segundo o melhor que se tem escrito a este assunto. Lisboa: Na Régia Officina Typográfica, 1798-1806. 5 tomos. A obra está dividida da seguinte maneira: Tomo 1, partes 1 e 2 - Da cultura das canas e fatura do açúcar; parte 3 - Do leite, queijo e manteiga; Tomo 2 - Tinturaria (3 partes); Tomo 3 Bebidas alimentosas, partes 1 e 2 - Cultura do café, parte 3 - Cacau; Tomo 4 - Especiarias; e Tomo 5 - Filatura.

92 DIAS, M. O. da S. Aspectos da Ilustração no Brasil, p. 120.

93 Tais como: Coleção de memórias inglesas sobre a cultura e comércio do linho cânhamo, tiradas de diferentes autores; Discurso prático acerca da cultura, maceração e preparação do cânhamo, lido e aprovado pela Real Sociedade Agrária de Turim, e dedicado à mesma sociedade por seu autor, publicadas em 1799; ou o Aviário brasílico ou galeria etimológica das aves indígenas do Brasil, disposto e descrito segundo o sistema de Carlos Linneu, copiado do natural e dos melhores autores, precedido de diversas dissertações análogas ao seu melhor conhecimento, acompanhado de outras estranhas ao mesmo continente, publicada em 1800.

94 VELOSO, J. M. da C. Naturalista instruído nos diversos métodos antigos e modernos de ajuntar, preparar e conservar as produções dos três reinos da natureza, coligido de diferentes autores, dividido em vários livros. Lisboa: Na Oficina da Casa Literária do Arco do Cego, 1800.
} 
Dedicatória do Naturalista instruído nos diversos métodos antigos e modernos de ajuntar, preparar e conservar as produções dos três reinos da natureza: "Espalhar estes conhecimentos, Senhor, é formar prosélitos de História Natural, ciência mãe de todas as que podem formar a felicidade do homem enquanto vive e, por conseqüência, fazer que ele seja um cidadão útil, um vassalo necessário". ${ }^{95}$

$\mathrm{Na}$ Tipografia reuniam-se também alunos e ex-alunos da Universidade de Coimbra naturais do Brasil, que compunham a Geração de 1790, entre os quais os irmãos Martin Francisco (1775-1844), e Antonio Carlos Ribeiro de Andrada (1773-1845), o primeiro, formado em Filosofia e Matemática em 1798, e o segundo, bacharel em Leis e Filosofia em 1797; e Hipólito da Costa. ${ }^{96}$ Refletindo sobre a arregimentação de letrados naturais da colônia para o trabalho na Tipografia do Arco do Cego, Diogo Ramada Curto chama a atenção para que a existência da tipografia deva ser compreendida também no âmbito do mecenato e das clientelas, típico das relações sociais do Antigo Regime: "A exemplo do que já se passara com a Academia das Ciências, a Casa Literária do Arco do Cego era uma forma de arregimentar intelectuais que, de outro modo, poderiam ter comportamentos sediciosos". ${ }^{97}$ Estes letrados ocupavam-se da escrita, tradução e publicação de estudos sobre ciências e artes que incluíam desde a descrição de maquinários, como a Descrição de uma máquina para tocar a bomba a bordo dos navios sem o trabalho de homens, oferecida a Real Marinha Portuguesa, escrita por Hipólito da Costa, até trabalhos de Economia Política, como os Princípios de direito mercantil e leis de marinha, primeira obra publicada por José da Silva Lisboa. $^{98}$

\footnotetext{
No plano da obra, Veloso afirma que "tem em vista dar tudo quanto se tem escrito a este assunto que se acha disperso por autores e línguas estranhas em um corpo, dividido em três ramos, segundo a divisão ordinária da História Natural em três reinos". O volume existente na Biblioteca Nacional do Rio de Janeiro, no entanto, contém somente a matéria referente ao reino animal. Trata-se da tradução de extratos de um Tratado sobre o modo de encher e de conservar os animais, do Abade Denis Joseph Manesse (1743-1820), escrito em 1786.

${ }^{5}$ VELOSO, J. M. da C. Naturalista instruído nos diversos métodos antigos e modernos de ajuntar, preparar e conservar as produções dos três reinos da natureza, coligido de diferentes autores, dividido em vários livros. Sem número de páginas.

${ }^{96}$ São geralmente lembrados pela historiografia também os de nomes de José Feliciano Fernandes Pinheiro (1774-1847), bacharel em Cânones em 1798; Vicente Coelho de Seabra (1764-1804), formado em Medicina em 1791; e e Manuel Jacintho Nogueira da Gama (1765-1847), formado em Matemática e Filosofia em 1790.

${ }^{97}$ CURTO, op.cit., p. 49. Ideia que, aliás, corrobora a argumentação de Kenneth Maxwell a respeito da formação da Geração de 1790.

${ }^{98}$ COSTA, H. J. da. Descrição de uma máquina para tocar a bomba a bordo dos navios sem o trabalho de homens, oferecida a Real Marinha Portuguesa. Lisboa: Tipografia Calcográfica e literária do Arco do Cego, 1800; LISBOA, J. da S. Princípios de direito mercantil e leis de
} 
Dedicava-se, contudo, especial atenção ao recolhimento de informações gerais sobre a produção agrícola já existente, e a verificação da possibilidade de novas culturas a partir de outros recursos existentes, principalmente, nas capitanias do Brasil. Destacam-se as memórias que tratam da cultura da cana de açúcar, considerada ainda a principal cultura da colônia, como é possível observar tanto da leitura da correspondência de Silva Lisboa para Vandelli, quanto da distribuição dos volumes de $O$ Fazendeiro do Brasil. Apenas no ano de 1800 foram publicados quatro trabalhos que versavam sobre o tema. Justificavam a sua importância chamando a atenção para o papel da cultura da cana-de-açúcar na economia do Império, e a necessidade de aperfeiçoar a sua cultura por meio de estudos que ilustrassem àqueles que se dedicavam a esse trabalho. ${ }^{99}$ Como afirma José Caetano Gomes no Proêmio da sua Memória sobre a cultura e produtos da cana de açúcar, o mais completo daqueles quatro trabalhos:

\begin{abstract}
A agricultura, a primeira, a mais útil das artes, que nutre a todas e faz a base da prosperidade e força dos Estados, não saiu ainda da infância no Brasil. Todas as plantas são cultivadas por costume e sem princípios; as Luzes da Europa culta chegam cá tão fracas que não podem aclarar-nos; as cousas mais triviais de que podíamos ter abundância não se sabem trabalhar. A cana-de-açúcar, sendo o vegetal mais precioso, comparado o seu produto com o que tiram os estrangeiros nas Antilhas é menos de a metade. Entregue a sua cultura a escravos conduzidos por um feitor, sem mais talentos que os que lhe sugere a sua ferocidade. A manufatura do açúcar e da aguardente, executada por ignorantes que não sabem a razão dos fatos, nem conhecem a natureza das diferentes partes que constituem os líquidos sobre que trabalham; os donos das fábricas olhando com indiferença para todos estes objetos, julgando-os indignos da sua aplicação; não é de admirar que, desta sorte, haja o atrasamento que se vê na cultura e produto da cana-de-açúcar. ${ }^{100}$
\end{abstract}

A Memória de Caetano Gomes aborda desde a descrição da planta até a fabricação da aguardente, passando pelo tratamento que deveria ser dado ao gado e bestas utilizadas na moagem da cana. $\mathrm{O}$ autor apresenta inclusive uma Teoria

marinha para uso da mocidade portuguesa destinada ao comércio, dividido em oito tratados elementares contendo a respectiva legislação pátria $e$ indicando as fontes originais dos regulamentos marítimos das principais praças de Europa. Lisboa: Tipografia Calcográfica, Tipoplástica e Literária do Arco do Cego, 1801.

${ }^{99}$ COSTA, H. J. da. Descrição da árvore açucareira, da sua utilidade e cultura, impressa de ordem superior. Lisboa: Tipografia Calcográfica e literária do Arco do Cego, 1800; SILVA, A. C. R. de A. M. e. Considerações cândidas e imparciais sobre a natureza do comércio do açúcar, trasladadas do inglês. Lisboa: Na Oficina da Casa Literária do Arco do Cego, 1800; GOMES, J. C. Memória sobre a cultura e produtos da cana de açúcar. Lisboa: Oficina Literária do Arco do Cego, 1800; e VELOSO, J. M. da C. Extrato sobre os engenhos de açúcar do Brasil e sobre o método já então praticado na fatura deste sal essencial, tirado da obra Riqueza e Opulência do Brasil. Lisboa: Na Tipografia Calcográfica e Literária do Arco do Cego, 1800.

${ }^{100}$ GOMES, J. C. op. cit., p. 11. 
para a cultura da cana-de-açúcar e os Princípios que devem conduzir o

fabricante de açúcar:

O que vou dizer é um extrato do que tenho visto sobre esta matéria. Os princípios para a cultura da terra, segundo os Antigos, que supunham as raízes das plantas como os únicos órgãos para receber sua nutrição, consistiam em lavrar a terra com diversos instrumentos para a pôr bem móvel, estrumá-la e depois de um certo numero de colheitas, dar-lhe descanso, quero dizer, conservá-la limpa sem nutrir planta alguma. (...) Estes princípios são certos em parte, e em parte diametralmente opostos ao fim que se busca. A quem ignorar os descobrimentos mais modernos, há de parecer paradoxo o dizer-se que a terra natural não concorre para a vegetação das plantas, que estas não tiram dela alimento algum, e que só serve de alicerce para suster a sua corporeidade. ${ }^{101}$

Gomes propõe inovações nas formas de plantio e corte da cana e na construção dos engenhos e funcionamento das moendas, sempre comparando com a forma mais comumente utilizada e apontando as vantagens do método que propõe. ${ }^{102}$ Seu trabalho inclui ainda 8 estampas representando as novas formas de plantar e moer a cana, o formato ideal da enxada a ser usada no plantio e a forma da sua utilização, forma de construir a casa de engenho e o alambique, entre outros. $^{103}$

Especialmente interessante também é o Extrato sobre os engenhos de açúcar do Brasil e sobre o método já então praticado na fatura deste sal essencial, tirado da obra Riqueza e Opulência do Brasil, para se combinar com os novos métodos que agora se propõem, escrito por Frei Veloso. Como informa o título da obra, os extratos são retirados do livro Cultura e Opulência do Brasil por suas Drogas e Minas, escrito pelo jesuíta italiano André João Andreoni

\footnotetext{
${ }^{101}$ Ibid., p. 5/6.

102 "Nenhum autor que trate de cana-de-açúcar manda plantá-la em menos distância que a de três pés, e alguns querem seis e sete, que são nove e dez palmos e meio de cova a cova. Isto há de parecer um paradoxo aos nossos lavradores, que até têm um ditado: quero cana mil, e não gentil. Porém, da perfeição com que nas colônias estrangeiras se faz esta cultura, a mais preciosa da América, é que tem procedido o grau de prosperidade a que se tem elevado, e de que somos privados por seguirmos somente um trilho cego e sem reflexão". Ibid., p. 5.

${ }^{103}$ Ressalta Miguel Figueira de Faria que um dos traços distintivos da Tipografia do Arco do Cego foi a utilização maciça da imagem nas suas obras. Principalmente na sua vertente informativa e didática, tirando partido da sua capacidade de síntese e de transmissão de conhecimentos para, nas palavras de Frei Veloso, "ajudar ao entendimento" ou "facilitar o conhecimento" das obras de História Natural. E, apesar de também ter cultivado outros interesses editoriais, principalmente por obras ilustradas de luxo, menos de $5 \%$ do total das gravuras produzidas pela Calcografia do Arco do Cego, compõe-se de imagens ornamentais: "Parece-nos, pois, consensual afirmarmos que, mesmo não negando a presença de uma função estética, as preocupações de Veloso acompanham as do próprio projeto editorial em que desempenhou papel determinante a componente técnica e científica particularmente nos domínios da História Natural e da Botânica e consequentemente da Agricultura e da Agronomia" (FARIA, M. F. de. Casa Literária do Arco do Cego: exemplo singular na História da edição ilustrada em Portugal. Apontamentos para uma biografia, p. 33).
} 
(1649-1726), sob o pseudônimo de João Antônio Antonil, em 1711. Antonil faz um apanhado da condição das principais atividades econômicas da colônia no início do século XVIII: a cana-de-açúcar, a mineração, a criação de gado e o tabaco. Na Dedicatória do seu Extrato, Veloso justifica a escolha da obra de Antonil:

Senhor, a obra que tenho a honra de apresentar a V.A.R. sobre o açúcar, segundo minha notícia, é a única que antecede, em nossa linguagem, às que de ordem de V.A.R. se tem impresso a favor dos empreiteiros deste granjeio no Brasil. Data dos princípios da centúria décima-oitava e se crê que seu autor ocultara o seu nome debaixo de outro suposto. $\mathrm{O}$ alvo em que fitou os seus olhos foi uma exposição simples das riquezas e opulências do Brasil, derivadas da cultura da cana, da criação do gado vacuum e da extração do ouro no sertão dos Cataguases (...). Quanto o autor escreve acerca da extração deste precioso sal essencial é mais devido aos seus olhos que ao seu entendimento; pois só descreve o que vira fazer nos mais célebres engenhos da Bahia, sem avançar o que deveriam fazer, isto é, coisa alguma sobre o seu melhoramento ou no todo, ou nas partes que o constituem. ${ }^{104}$

A obra de Antonil foi considerada perigosa pelo detalhamento das informações que continha e logo proibida e recolhida. O Extrato de Veloso referente à cana-de-açúcar seria, pois, a primeira edição de alguma parte da obra de Antonil depois da sua proibição, uma vez que o texto completo só viria a público novamente em edição de 1837 . Veloso menciona essa censura sofrida pela obra de Antonil, ressaltando como a intenção de promoção das Luzes por D. João sobrepujava e desautorizava aquela proibição:

Um fatal veto, ao depois de ter visto a luz pública pelo benefício do prelo, veio estropiar a carreira desta obra, que nada parecia conter contra a Santidade das Leis Religiosas, Políticas e Morais, como julgaram seus censores. O resultado não foi de menor fatalidade, porque se veio a entender que, não havendo um vício sobre que ele caísse, se não consentiria a impressão de obras desta natureza, ainda sendo melhores. (...) Graças a V.A.R. que, mandando trasladar para o Fazendeiro do Brasil o que escreveram Bryan Edward, o anônimo autor da Cultura Americana, Du Hamel Du Monceau, Dutrone de la Couture sobre este assunto, e outros sobre outros análogos que constituem os interessantes objetos da economia rural das colônias brasilianas, lhes tem patenteado com toda a evidência e energia a nulidade daquele veto. ${ }^{105}$

A compilação reproduz tudo o que escreveu Antonil na sua obra a respeito da cultura do açúcar (35 capítulos), incluindo aí as reflexões daquele autor a

\footnotetext{
${ }^{104}$ VELOSO, J. M. da C. Extrato sobre os engenhos de açúcar do Brasil, sem numeração de páginas.

${ }^{105}$ Ibid.
} 
respeito da posição social dos senhores de engenho na sociedade colonial. ${ }^{106} \mathrm{~A}$ compilação de Veloso extrapola, por isso, o caráter de uma memória técnica sobre a cultura do açúcar. Apesar da intenção manifesta de fazer um cotejamento entre a maneira como se produzia o açúcar no início do século XVIII e os melhoramentos que a produção ilustrada do final do século propunha a esta cultura, Veloso não adiciona ao texto notas ou correções. Caberia a quem lesse o seu Extrato fazer tal cotejamento com os tratados mais recentes.

Entre as publicações da Tipografia do Arco do Cego podem-se encontrar ainda memórias sobre diversas outras culturas como o arroz, o cânhamo ou mesmo apicultura. ${ }^{107}$ Particularmente célebre é a Memória sobre a cultura dos algodoeiros e sobre o método de o escolher e ensacar, escrita em 1797 por Manuel Arruda da Câmara (1752-1811) e publicada pela Tipografia do Arco do Cego dois anos depois. As informações biográficas acerca de Arruda da Câmara são controversas. Religioso da Ordem dos Carmelitas (professo no Convento da Ordem da Vila de Goiana, capitania de Pernambuco, em 25 de novembro de 1783), ingressou no curso de Filosofia da Universidade de Coimbra em 27 de outubro de 1786, que posteriormente abandonou, matriculando-se no curso de Medicina da Universidade de Montpellier, em 15 de agosto de 1790, em conjuntura agitada da história da França. Na mesma ocasião, Câmara abdica da condição de religioso, sendo desligado definitivamente da ordem em 13 de julho de 1805 .

Autores que se ocuparam dessa personagem chamam sempre a atenção para a sua controversa atuação política. Alguns desenham um perfil republicano e revolucionário para Arruda da Câmara, por suas possíveis relações com a França Revolucionária durante os anos que estudou em Montpellier, além de seu envolvimento com a fundação do Areópago de Itambé, por meio do qual seria um dos introdutores da maçonaria em Pernambuco, e inspirador da Revolução Pernambucana de 1817. Esses autores consideram que ele tinha mesmo um

\footnotetext{
${ }^{106}$ Por exemplo, os capítulos 10, Como se há de haver o senhor de engenho no governo da sua família e nos gastos ordinários da casa, e 11, Como se há de haver o senhor de engenho no recebimento dos hóspedes, assim religiosos como seculares.

${ }^{107}$ TELLES, V. C. de S. da S. Memória sobre a cultura do arroz em Portugal e suas conquistas, oferecida a Sua Alteza Real. Lisboa: Na Oficina da Casa Literária do Arco do Cego, 1800; ARAGÃO, F. de F. e. Tratado histórico e físico das abelhas. Lisboa: Na Officina da Casa Litteraria do Arco do Cego, 1800; CHABOUILLÉ-DUPETITMONT. Manual prático do lavrador com um tratado sobre as abelhas, traduzido do francês por José Ferreira da Silva. Lisboa: Na Tipografia Calcográfica e Literária do Arco do Cego, 1801.
} 
projeto político de emancipação da colônia. ${ }^{108}$ Enquanto outros autores preferem chamar a atenção para a sua adesão ao projeto de reformas ilustradas de D. Rodrigo de Sousa Coutinho, atentando para as demonstrações de vassalagem a D. João e de gratidão a D. Rodrigo que podem ser encontradas nas dedicatórias das suas obras: "Senhor, não foi a vaidosa lembrança de querer inscrever nesta minha pequena obra o augusto nome de Vossa Alteza Real, o melhor dos Príncipes, o mais amável dos Soberanos, foi sim o meu reconhecimento, a minha vassalagem". 109

De volta ao Brasil, Arruda da Câmara procurou conciliar os seus interesses pela História Natural com um meio de vida que lhe garantisse a subsistência. Como explica na Introdução da sua Memória sobre a cultura dos algodoeiros, sonhava com um engenho, onde tinha o propósito de contribuir para o aperfeiçoamento da cultura da cana-de-açúcar. Não tendo a oportunidade de possuir um engenho, realizou suas observações em uma fazenda onde plantava algodão, à margem do Rio Paraíba. Foi das observações feitas nesse trabalho que saiu a sua Memória sobre a cultura dos algodoeiros, "uma enciclopédia do algodoeiro situado nos trópicos brasileiros", como a define José Antonio Gonsalves de Mello:

Versando nele desde a história do uso antigo do algodão, às variedades botânicas, solo apropriado (segundo ele, as várzeas), clima, métodos de plantio e cultivo,

\footnotetext{
${ }^{108}$ A esse respeito ver, por exemplo, Maria Rachel Fróes da Fonseca: “A preocupação com a informação, característica na trajetória de Arruda da Câmara, apresentava igualmente uma outra dimensão que não a científica, qual seja, a informação em torno das ideias políticas em voga no Velho Continente. Neste sentido, no retorno ao Brasil em 1798, trazia um projeto político, o qual segundo depoimentos da época, seria o de buscar os meios para implantar o sistema republicano no Brasil. Esta preocupação política o teria levado a criar, nesta ocasião, uma sociedade política e secreta, denominada Areópago de Itambé”. FONSECA, M. R. F. da. Luzes das Ciências na Corte Americana: Observações sobre o periódico "O Patriota", p. 93.

${ }^{109}$ CÂMARA, M. A. da. Memória sobre a cultura dos algodoeiros e sobre o método de o escolher e ensacar. In: MELLO, J. A. G. de. Manuel Arruda da Câmara: obras reunidas c. 1752-1811. p. 111. José Antonio Gonsalves de Mello, na Introdução que escreve à edição das Obras Reunidas de Arruda da Câmara, analisa a controvérsia existente em torno da Dedicatória da Memória sobre a cultura dos algodoeiros. Segundo Gonsalves de Mello, esse trabalho teria sido originalmente oferecido a D. Rodrigo, sendo alterada a Dedicatória por Frei Veloso, no momento da sua publicação, passando a ser oferecida a D. João. Gonsalves de Mello também analisa os documentos do século XIX a partir dos quais se construiu a fama de republicano de Arruda da Câmara, questionando a sua autenticidade e fidedignidade: "Um centro de ação cultural e política que teria sido criado por ele para debates literários e difusão de idéias republicanas e de iniciação maçônica, fato admitido como inconteste na História brasileira, vem revelar uma inacreditável leviandade da parte de alguns dos nossos historiadores, que acolheram certas informações sem considerar que os 'documentos' nos quais elas se apoiaram jamais foram vistos por outrem senão por quem as divulgou pela primeira vez - sendo o divulgador suspeito de uma falsidade histórica". MELLO, op. cit., p. 12.
} 
moléstias e pragas que o afetam, descaroçamento e ensacamento do produto. ${ }^{110}$

Seguindo o espírito ilustrado das demais memórias publicadas pelo Arco do Cego, o trabalho de Câmara procura instruir aos produtores de algodão, desfazendo alguns erros perpetuados por uma prática "não-científica" daquela cultura. Dessa forma, ao discorrer sobre a melhor maneira de plantar os algodoeiros, Câmara propõe um método novo, em oposição ao comumente utilizado pelos agricultores, alertando para a ignorância de não adotá-lo:

Há agricultores que (...) refusam este método de plantar. Mas estes são do número daqueles que por evitarem um pequeno incômodo presente, se privam de tantos bens futuros, funestos efeitos da preguiça, maior causa da pobreza e do descômodo da vida. ${ }^{111}$

Como explica Diogo Ramada Curto, a tipografia do Arco do Cego inscrevia-se no âmbito de uma política colonial que realçava o Brasil, sem esquecer a Índia: "E a produção tipográfica de obras relativas à América portuguesa (...) era um imperativo, num momento em que a prosperidade comercial da metrópole se lhe devia". ${ }^{112}$ Segundo reflexão de Manoel Luiz Salgado Guimarães, o rol de temas que constituíam as preocupações das publicações emanadas da Tipografia do Arco do Cego parece indicar um saber a serviço da Ilustração, mas também adequado às necessidades do Estado: "um verdadeiro leque de preocupações próprias de um projeto de natureza iluminista aliado às especificidades de Portugal e de seu império ultramarino". ${ }^{113}$

\footnotetext{
${ }^{110}$ MELLO, op. cit., p. 28. A Memória está dividida em 10 capítulos, da seguinte forma: Capítulo 1 - Da antiguidade do uso do algodão e da vantagem que tem resultado a Portugal e Paranambuc [sic] a sua cultura; Capitulo 2 - Da descrição do algodoeiro; Capítulo 3 - Da terra mais própria ou mais conveniente para a cultura dos algodoeiros; Capitulo 4 - Do clima ou temperatura do ar mais conveniente à vegetação do algodoeiro; Capítulo 5 - Da melhor maneira de plantar os algodoeiros; Capítulo 6 - Das operações que se devem fazer aos algodoeiros, para produzirem melhor qualidade e maior abundância de algodão; Capítulo 7 - Das moléstias a que são sujeitos os algodoeiros; Capítulo 8 - Da monda; Capítulo 9 - Da colheita do algodão; Capítulo 10 - Do descaroçamento e ensacamento.

${ }^{111}$ Ibid., p. 131. Da mesma forma, ao abordar os processos de descaroçamento e ensacamento do algodão, Câmara descreve duas máquinas de sua autoria, das quais fornece também estampas ilustrativas, que tinham a função não apenas de facilitar, mas também de aumentar a produtividade desses dois processos que, pelo que escreve, pareciam ser os mais trabalhosos de toda a cultura do algodão. A respeito do processo de ensacamento, afirma Câmara que: "O trabalho fatigante desta operação e alguma curiosidade que exige da parte de quem ensaca, faz com que os negros se neguem a este trabalho, por cuja razão são contados os ensacadores e logram um preço distinto. Isto, e o vagar com que se ensaca, me picaram desde que principiei a empregar-me nesta cultura a descobrir um meio pelo qual obstasse a tantos inconvenientes, sendo um deles a rotura que, por semelhantes métodos, se fazem nos sacos". Ibid., p. 155/156.

${ }_{112}$ CURTO, op. cit., p. 48.

${ }^{113}$ GUIMARÃES, op. cit. p. 72.
} 
A tipografia do Arco do Cego foi extinta pelo decreto de D. Rodrigo de 7 de dezembro de 1801. Esse mesmo decreto também reorganizou a Impressão Régia de Lisboa, criada pelo alvará de 24 de dezembro de 1768, transferindo para essa instituição o pessoal e oficinas da antiga tipografia. ${ }^{114}$ Frei Velloso e Hipólito da Costa foram nomeados para o cargo de Diretores Literários da Impressão Régia, encarregados da tradução e revisão de obras, além de influírem na decisão sobre quais obras publicar. $\mathrm{O}$ mesmo decreto determinava que se continuasse a fazer

A impressão dos livros e obras de que se achava encarregada a Casa Literária do Arco do Cego, e particularmente das obras botânicas de Frei José Mariano da Conceição Velloso, e fazendo acabar todas as obras que se acham ali principiadas e que deverão concluir-se. ${ }^{115}$

Significativamente, D. Rodrigo extinguia o trabalho da Tipografia do Arco do Cego no mesmo ano em que deixava a Secretaria de Estado da Marinha e Domínios Ultramarinos para assumir a Presidência do Erário Régio, ao qual a Impressão Régia de Lisboa estava subordinada. Dessa forma, transferia as funções de difusão de conhecimentos científicos sobre e para o Império Português para outra tipografia que continuaria sob o seu comando. Assim sendo, pode-se afirmar, como faz Nívia Pombo Cirne dos Santos, que esse trabalho de impressão e divulgação encontrava-se no centro das preocupações de D. Rodrigo e de seu projeto de reformas ilustradas para o Império. ${ }^{116}$

A Impressão Régia do Rio de Janeiro foi criada por decreto do Príncipe Regente de 13 de maior de 1808, segundo Rubens Borba de Moraes, devido a necessidade urgente de dar publicidade aos atos do governo, que vinha legislando desde a chegada de D. João à Bahia, em 22 de janeiro, onde assinou vários atos (inclusive a Carta Régia de abertura dos portos). Significativamente também, a

\footnotetext{
114 Como afirma Manoel Salgado Guimarães: "Percebem-se, portanto, os fortes laços que conectam os referidos projetos intelectuais, quer quanto à forma de organização e disposição do saber, quer quanto aos horizontes de crenças e valores que partilham". Ibid., p. 72.

${ }^{115}$ Reprodução da íntegra do decreto em VARNHAGEN, Francisco Adolfo de. História Geral do Brasil. Tomo quinto. p. 44/45.

${ }^{116}$ SANTOS, op. cit., p. 217 a 222. Nívia chama a atenção também para a importância da criação da Sociedade Real Marítima, Militar e Geográfica para o Desenho, Gravura e Impressão das Cartas Hidrográficas, Geográficas e Militares, criada em 1798, no projeto de reformas ilustradas de D. Rodrigo (SANTOS, op. cit., p. 214 a 217). Também Íris Kantor aponta para a inserção do trabalho da Sociedade Real Marítima naquele projeto, em conjunto com as expedições científicas ao Ultramar e o trabalho de edição do Arco do Cego. Como afirma a autora: "a extensão das luzes reformistas dependia de um mais exato conhecimento dos domínios e da promoção de comunicações interiores com o objetivo de buscar a melhoria das culturas". KANTOR, I. Mapas em trânsito: projeções cartográficas e processo de emancipação política do Brasil (1779-1822), p. 118.
} 
nova tipografia, estando subordinada à Secretaria dos Negócios Estrangeiros e da Guerra, continuava sob a direção de D. Rodrigo de Sousa Coutinho:

Tendo-me constado que os prelos que se acham nesta Capital, eram os destinados para a Secretaria de Estado dos Negócios Estrangeiros e da Guerra; e atendendo à necessidade que há da Oficina de Impressão nestes Meus Estados: Sou servido que a casa onde eles se estabeleceram sirva interinamente de Impressão Régia, onde se imprimirão exclusivamente toda a Legislação e Papéis Diplomáticos, que emanarem de qualquer Repartição do Meu Real Serviço; e se possam imprimir todas, e quaisquer obras; ficando interinamente pertencendo o seu governo e administração à mesma Secretaria. Dom Rodrigo de Sousa Coutinho, do Meu Conselho de Estado, Ministro e Secretario de Estado dos Negócios Estrangeiros e da Guerra, o tenha assim entendido, e procurará dar ao emprego da Oficina a maior extensão, e lhe dará todas as instruções e ordens necessárias, e participará a este respeito a todas as Estações o que mais convier ao Meu Real Serviço. Palácio do Rio de Janeiro em treze de maio de mil oitocentos e oito. Com a Rubrica do Príncipe Regente N. S. ${ }^{117}$

Dava continuidade, assim, na nova sede da monarquia, ao trabalho executado pela sua homônima lisboeta, não apenas publicando os atos oficiais, mas também mantendo a função de difusora das Luzes no Império português, e de censora das perigosas ideias revolucionárias francesas. Apresentando-se como a face cultural do projeto político do reformismo ilustrado português, uma vez que não havia outras tipografias na América portuguesa. ${ }^{118}$ Como explica Lúcia Maria Bastos Pereira das Neves, entre as muitas instituições culturais criadas nessa

117 Apud. MORAES, R. B. de. Livros e Bibliotecas no Brasil Colonial, p. 99/100. Até a transferência da corte para o Rio de Janeiro, o Secretário de Estado dos Negócios Estrangeiros e da Guerra era Antonio de Araujo e Azevedo, caído em desgraça por encabeçar o denominado Partido Francês, que defendia o entendimento com os franceses na delicada conjuntura diplomática que antecedeu à transferência da Corte para a América. Ao estabelecer-se o aparelho de Estado na nova sede da monarquia, Azevedo foi preterido em benefício de Sousa Coutinho, anteriormente Secretário dos Negócios da Marinha e Domínios Ultramarinos, defensor da aliança com a Inglaterra. Não obstante, o primeiro local de funcionamento da tipografia, segundo alguns autores, teria sido no térreo da residência de Azevedo, localizada na esquina da Rua das Marrecas com a Rua do Passeio, segundo Laurence Hallewell, ou com a rua dos Barbonos, segundo Rubens Borba de Moraes (CAMARGO, A. M. de A. \& MORAES, R. B. de. Bibliografia da Impressão Régia do Rio de Janeiro, vol. 1, p. XVII A XXXI; HALLEWELL, op. cit., p. 35). Após a queda de Napoleão e a retomada das relações diplomáticas com a França, Azevedo voltará a ocupar um papel de destaque no governo português.

118 Além da Impressão Régia do Rio de Janeiro, a única tipografia autorizada a funcionar regularmente nesse período foi a tipografia de Antônio da Silva Serva, na antiga capital da colônia, Salvador. Comerciante português estabelecido em Lisboa, em abril de 1797 Silva Serva pediu autorização para viajar para o Brasil, estabelecendo-se em Salvador, onde abriu loja onde vendia lustres para sala, encerados e alcatifas, vidros da Boêmia, móveis, quadros, rapé e livros. A 18 de dezembro de 1810 dirigiu um requerimento ao Conde dos Arcos, governador da Bahia, pedindo autorização para abrir uma tipografia (cópia desse requerimento encontra-se publicada em CASTRO, R. B. de A primeira imprensa da Bahia e suas publicações, p. 17/18). A autorização de funcionamento da tipografia foi concedida pelo Príncipe Regente por carta régia datada de 5 de fevereiro de 1811, onde ficava estabelecida também a forma como deveria ser exercida a censura das obras a serem publicadas (cópia em CASTRO, op. cit., p. 23/24). 
conjuntura, a Impressão Régia se caracterizou pela sua função de difundir aquilo que devia fazer parte da formação intelectual da elite do império português, por um lado; e por outro, excluir o que devia ficar de fora dessa formação, por meio da censura:

Tratava-se, sem dúvida, de um projeto cultural e político voltado para a homogeneização das elites e para o estabelecimento de uma felicidade pública em moldes ilustrados. Contudo, na esteira da Revolução francesa e em época de guerras napoleônicas, devia constituir também um meio de conter a propaganda e a infiltração de franceses e de suas idéias, consideradas perigosas. ${ }^{119}$

Maria Odila da Silva Dias chama a atenção para a filiação entre a Impressão Régia do Rio de Janeiro e suas antecessoras reinóis, ao comentar as atividades de D. Rodrigo de Sousa Coutinho no Brasil. Segundo a autora, o estadista retomou na Impressão Régia do Rio de Janeiro, “a publicação de trabalhos por ele encomendados de 1798 a 1803, patrocinando novos estudos, de orientação prática, para servirem ao progresso das artes, técnicas, da lavoura e da pecuária”. ${ }^{120} \mathrm{O}$ que fica comprovado pelo fato de que a Impressão Régia do Rio de Janeiro publicou, muitas vezes, memórias sobre História Natural escritas pelos mesmos autores que publicavam na Tipografia do Arco do Cego.

Em 1810, por exemplo, a tipografia criada na nova sede do Império publicou duas memórias de Manuel Arruda da Câmara: a Dissertação sobre as plantas que podem dar linhos e o Discurso sobre a instituição de jardins nas principais províncias do Brasil. Na primeira, o autor se propõe a analisar 14 espécies com capacidade para substituir o cânhamo, fazendo a sua descrição morfológica e caracterizando sua importância econômica (seus usos, forma de extração do linho, custos da sua cultura e da sua comercialização e sugestões para o seu barateamento). ${ }^{121}$ Enquanto no Discurso sobre a instituição de jardins, Câmara advoga a necessidade de fundação de pelo menos 4 estabelecimentos desse gênero na América portuguesa, como a melhor forma de fazer a transplantação de plantas de outros pontos do Império, assim como de várias capitanias do Brasil. Reafirmando, dessa forma, a importância dos Jardins Botânicos para o desenvolvimento do conhecimento da História Natural,

\footnotetext{
${ }^{119}$ NEVES, L. M. B. P. das. Da Repulsa ao Triunfo - idéias francesas no Império Luso-Brasileiro, $1808-1815$, p. 37.

${ }^{120}$ DIAS, op. cit., p. 126.

${ }^{121}$ CÂMARA, M. A. da. Dissertação sobre as plantas do Brasil que podem dar linhos próprios para muitos usos da sociedade e suprir a falta de cânhamo. In: MELLO, op. cit., p. 163 a 193.
} 
procedimento estabelecido em Portugal desde o fim do século anterior. ${ }^{122}$ Câmara preocupava-se com a preservação de espécies ameaçadas de destruição, chamando a atenção para a importância do seu conhecimento e preservação:

O reino vegetal é sem dúvida a fonte mais fecunda, mais pronta e menos trabalhosa das riquezas de qualquer Nação; e todo o cuidado em promover este manancial de felicidade pública será pouco à vista do imenso proveito que daí se pode tirar. Dos vegetais é que se extrai o sustento dos homens, os seus vestidos e enfeites; os regalos da vida, os remédios das enfermidades; a matéria primeira das Artes; a Agricultura, pois, é a verdadeira mãe das Artes, do Comércio e da Navegação. ${ }^{123}$

Outro aspecto da continuidade entre o trabalho da Tipografia do Arco do Cego e da Impressão Régia do Rio de Janeiro foi a reedição, por esta última, de obras escritas no final do século XVIII, algumas já publicadas pela tipografia de Frei Veloso. É o caso da Memória sobre a Canela do Rio de Janeiro, de Bernardino Antonio Gomes, publicada no Rio de Janeiro em 1809. Na folha de rosto há a informação de que ela foi escrita, "a rogo do Senado da Câmara" do Rio de Janeiro, na data de 8 de maio de $1798 .{ }^{124}$ Assim como nas já citadas memórias sobre outras culturas, Gomes aponta as falhas decorrentes de um cultivo nãoilustrado e a má utilização do potencial econômico da caneleira no Rio de Janeiro, apesar do clima e do solo dessa capitania não ser o ideal para essa cultura:

Neste ditoso país onde, bem como por toda a parte, é a negligência dos habitantes na razão direta da liberalidade da natureza, apenas as folhas desta árvore eram de algum uso. Preparavam com elas uma água aromática de que se não serviam mesmo senão para jogar o entrudo. Tão pouca era a utilidade que tiravam desta árvore que, independentemente da canela, porque aliás é cultivada e tão célebre, é muito preciosa ainda por outros títulos. ${ }^{125}$

\footnotetext{
${ }^{122}$ Por incentivo de D. Rodrigo, em 1796 começou a funcionar o Horto botânico de Belém, no estado do Grão-Pará e Rio Negro, governado então pelo seu irmão, D. Francisco de Souza Coutinho. Dois anos depois, D. Rodrigo enviava uma carta aos governadores de Pernambuco, Bahia, Minas Gerais, Goiás, São Paulo e Maranhão, ordenando a instalação de hortos nessas capitanias. O de Pernambuco ficaria sob a direção de Arruda da Câmara. No seu Discurso de 1810, Câmara propõe o estabelecimento de Jardins Botânicos no Rio de Janeiro, Bahia, Pernambuco, Pará e Caiena (esta última, conquistada aos franceses em 1809). Uma vez que já existiam Jardins nessas duas últimas, faltaria criar apenas nas outras três capitanias (CÂMARA, M. A. da. Discurso sobre a instituição de jardins nas principais províncias do Brasil. In: MELLO, op. cit., p. 203). A respeito do Jardim Botânico do Rio de Janeiro, apesar de ter recebido as suas primeiras plantas em 1809, contrabandeadas das Ilhas Maurício pelo oficial da Armada Real Luís de Abreu Vieira e Paiva, o seu decreto de criação é o Alvará de $1^{\circ}$ de março de 1811.

${ }^{123}$ Ibid., p. 199.

${ }^{124}$ GOMES, B. A. Memória sobre a canela do Rio de Janeiro, oferecida ao Príncipe do Brasil nosso senhor pelo Senado da Câmara da mesma cidade do ano de 1798. Rio de Janeiro: Na Impressão Régia, 1809. Gomes é, igualmente, o autor de uma Memória sobre a ipecacuanha fusca do Brasil ou cipó das nossas boticas, publicada pela Tipografia do Arco do Cego em 1801.

${ }^{125}$ Ibid., p. $39 / 40$.
} 
Na divulgação dessa cultura ilustrada em território colonial, desempenharam importante papel também os periódicos publicados pela Impressão Régia do Rio de Janeiro. Ainda que não fosse um periódico destinado exclusivamente à divulgação científica, a Gazeta do Rio de Janeiro desempenhou esse papel ao dar notícias da produção de obras, textos, cursos e publicar, ocasionalmente, memórias técnicas com algum conteúdo científico. É possível encontrar no periódico escassos artigos versando sobre conhecimentos científicos, que ocupavam as edições da Gazeta principalmente quando não havia novidades políticas relevantes a serem publicadas.

Em abril de 1812, por exemplo, a Gazeta do Rio de Janeiro publicou uma grande matéria sobre o anil, dividida em quatro partes durante quatro números sucessivos do periódico. ${ }^{126}$ Em algumas edições (como na de 11 de abril) ela ocupa quase duas páginas, enquanto que em outras (como na de 15 de abril) são publicados apenas dois ou três parágrafos, dando a nítida impressão de que a matéria estava ali para preencher o espaço deixado pela falta de notícias. Essa impressão é reforçada pelo fato de que no final da quarta parte da matéria, publicada na edição de 18 de agosto, há o aviso "continuar-se-há” indicando que a matéria não terminava ali. $\mathrm{O}$ periódico, todavia, não retorna ao assunto provavelmente por falta de espaço, e a matéria permanece inconclusa. A matéria, intitulada Noções sobre o anil, segue as mesmas características pragmáticas do memorialismo científico ilustrado português, apresentando a descrição e classificação científica da planta, suas formas de cultivo, de fabricação da tinta, análise da composição química da tinta e, principalmente, a importância econômica e estado atual do comércio do anil no Império português. A respeito desse último ponto, escreve o autor:

O distrito em que tem caído na Europa o anil do Brasil, o qual tendo todas as razões para formar um avultado ramo do comércio de exportação neste país, se acha reduzido a um sumo estado de decadência pela negligência com que até agora tem sido fabricado, que lhe tem alcançado o último lugar nos preços correntes estrangeiros, nos obriga a transcrever aqui a benefício do comércio as seguintes observações, que são necessárias para se conhecer no trato mercantil a qualidade do anil, a fim de que nossos comerciantes, acostumando-se a não exportar senão o bom anil, possam restituir a reputação a esta preciosa parte de nossas riquezas nacionais. ${ }^{127}$

\footnotetext{
${ }^{126} \mathrm{~N}^{\mathrm{o}} 29$, de 8 de abril; $\mathrm{n}^{\mathrm{o}} 30$, de 11 de abril, $\mathrm{n}^{\mathrm{o}} 31$, de 15 de abril e $\mathrm{n}^{\mathrm{o}} 32$, de 18 de abril.

${ }^{127}$ Gazeta do Rio de Janeiro, $\mathrm{n}^{\mathrm{o}}$ 32, 18 de abril de 1812.
} 
Em setembro de 1816, o periódico publica um extenso discurso de Georges Leopold Chrétien Cuvier (1769-1832), secretário perpétuo da Academia das Ciências da França, intitulado Reflexões sobre a marcha atual das ciências $e$ sobre todas as suas relações com a sociedade, por M. Cavaleiro Cuvier, Secretário perpétuo da Academia das Ciências, para as ciências físicas; lidas na sessão pública de instalação a 24 de abril de 1816, retirado do Le Moniteur, que se estende por três números consecutivos do periódico. ${ }^{128}$ Mais uma vez, as três partes em que se divide a matéria são muito desiguais. Enquanto a edição de 14 de setembro é quase completamente tomada pelo discurso de Cuvier, na edição seguinte, a publicação do discurso não ocupa nem uma página inteira. No seu discurso, Cuvier faz uma profissão de fé no progresso contínuo do conhecimento científico, relacionando as descobertas e invenções mais recentes, como o desenvolvimento da astronomia e a invenção da máquina a vapor, e seu impacto na vida dos homens, no desenvolvimento do comércio e da indústria e também no equilíbrio de poder entre as nações, não estabelecendo uma diferenciação entre as ciências e as artes, como eram entendidas na virada do século XVIII para o XIX:

Doce, mas infalível perspectiva, época feliz, que os erros dos governos e as imprudências dos povos pode afastar sem dúvida, mas que não embaraçarão de chegar, em que a ciência, a riqueza e a indústria, não tendendo mais do que a ajudarem-se mutuamente, aumentar-se umas por outras, levarão a prosperidade dos homens ao ponto que lhe é concedido tocar sobre a Terra! ${ }^{129}$

A inserção das matérias de cunho científico na Gazeta do Rio de Janeiro se deve, muito certamente, à atuação Manuel Ferreira de Araújo Guimarães (17771838) como redator do periódico entre 1812 e 1821 . Natural da Bahia, diplomado em Matemática pela Universidade de Coimbra, aluno e depois professor da Academia Real de Marinha em Portugal (de 1791 a 1805) e também da instituição congênere fundada por D. João no Rio de Janeiro em 1809, capitão do Corpo de Engenheiros, latinista, poeta e político, Araújo Guimarães foi autor de obras de caráter científico e tradutor de diversos manuais para uso nas instituições de ensino que lecionava, sendo um típico representante da Ilustração portuguesa. ${ }^{130}$

\footnotetext{
${ }^{128} \mathrm{~N}^{\mathrm{o}} 74$, de 14 de setembro, $\mathrm{n}^{\mathrm{o}} 75$, de 18 de setembro e $\mathrm{n}^{\mathrm{o}} 76$, de 21 de setembro.

${ }^{129}$ Gazeta do Rio de Janeiro, $\mathrm{n}^{\circ} 76$, de 21 de setembro de 1816.

${ }^{130}$ Uma lista dos manuais traduzidos por Guimarães pode ser encontrada no artigo de José Carlos de Oliveira A cultura científica e a Gazeta do Rio de Janeiro (1808-1821), onde o autor analisa o papel desempenhado pelo periódico na constituição da cultura científica na colônia durante o reinado de D. João (OLIVEIRA, J. C. de. A Cultura científica e a Gazeta do Rio de Janeiro (1808-
} 
Araújo Guimarães voltou ao cargo de redator da Gazeta do Rio de Janeiro depois da separação política entre Portugal e Brasil, durante o primeiro reinado (entre 1826 e 1830). No processo de Independência do Brasil, acompanhou a posição de D. Pedro e de seu grupo político e, mantendo a linha de intelectual patriótico, foi um dos inventores da comemoração do 7 de setembro como data da independência nacional. Como sintetiza Marco Morel:

Vê-se que Araújo Guimarães era um homem de letras e de ciências que fez sua carreira vinculada ao Estado, português e depois brasileiro, sem ser exatamente administrador ou um representante político destacado. (...) Era o que poderíamos chamar de intelectual profissional, no sentido gramsciano, certamente um dos primeiros nascidos no Brasil a ter esta condição. ${ }^{131}$

Além de redator da Gazeta, Araújo Guimarães foi o fundador e principal redator do primeiro periódico dedicado à cultura e às ciências produzido na colônia: O Patriota: Jornal literário, político e mercantil, publicado entre janeiro de 1813 e dezembro de 1814. No Prospecto do novo periódico, publicado pela Impressão Régia em 1812, Araújo Guimarães explicitou a principal motivação para a sua criação. Segundo ele, a Gazeta do Rio de Janeiro, único periódico da nova Corte até então, pelo seu tamanho e caráter noticioso, não era apropriada para a publicação de memórias científicas, muito mal desempenhando o seu papel de divulgar as notícias políticas:

\begin{abstract}
Não existindo nessa Corte algum periódico além da Gazeta, a qual pela sua pequena extensão não é suficiente para abranger todas as notícias políticas, escapando-lhe mormente aquelas peças oficiais mais longas, que exigiriam ou a multiplicidade daqueles números ou uma repetida interrupção, tão desagradável ao leitor; e não sendo em conseqüência possível ao redator acomodar na mesma, como projetara, notícias literárias e mercantis, quer nacionais, quer estrangeiras, pareceu acertado lançar mão de um jornal que satisfizesse a todos estes importantes objetos e que de passo servisse à publicação de muitas obras inéditas. ${ }^{132}$
\end{abstract}

1821), p. 36). Também é possível encontrar anúncios da publicação de traduções feitas por Araújo Guimarães na seção de Avisos da Gazeta do Rio de Janeiro: "Saíram à luz: Elementos de Geometria de Le Gendre, traduzidos por Manoel Ferreira de Araújo Guimarães, capitão do Real Corpo de Engenheiros e lente de Matemática na Academia Real dos Guardas-Marinhas, e juntamente: Tratado de Trigonometria, do mesmo autor, traduzido pelo mesmo. Mandada imprimir uma e outra obra por S.A.R., e destinada pelo mesmo Augusto Senhor para o uso da Academia Militar, o que tanto recomenda o merecimento da obra, como manifesta o paternal cuidado de S. A. R. na educação de seus vassalos. Vendem-se juntos por 1600 réis na Loja da Gazeta e na de Manoel Jorge na rua do Rosário". Gazeta do Rio de Janeiro, n 115, 18 de outubro de 1809 .

131 MOREL, M. Pátrias polissêmicas: República das Letras e imprensa na crise do Império Português na América, p. 24/25.

${ }^{132}$ GUIMARÃES, M. F. de A. Prospecto (do Patriota). Rio de Janeiro: Impressão Régia, 1812. 
Nesse Prospecto, Araújo Guimarães aponta também para o significado do título do periódico, expressando o sentido de patriotismo sintetizado na epígrafe escolhida pelo redator, os versos do escritor e humanista português Antonio Ferreira (1528-1569), "Eu desta glória só fico contente / Que a minha terra amei, e a minha gente". Como afirma Araújo Guimarães:

Quem combinar esta difícil tarefa com os gastos que ela exige, se convencerá facilmente de que o redator não tem em vista o próprio interesse, mas sim a pública utilidade e a glória da nação, e será muito feliz se os seus trabalhos satisfizerem à epigrafe que tem escolhido. ${ }^{133}$

Refletindo sobre o significado do título do periódico, Marco Morel chama a atenção para a polissemia de que se revestiam termos como Pátria (e seu derivado Patriota) e Nação, no início do século XIX. Explica Morel que o termo Pátria deve ser entendido como o local de nascimento (nesse sentido, a pátria de um baiano, por exemplo, seria a Bahia e não o Brasil), mas também pode ser entendido no âmbito do periódico como espaço de atuação intelectual de letrados. Tão pouco ao se referirem à nação, os letrados que publicavam no periódico estavam se referindo ao Brasil. Explica Morel que entre 1808 e 1815 houve, no mundo ibérico, o florescimento de um "patriotismo imperial”, de caráter antinapoleônico, que surgia como defesa da integridade e das identidades das monarquias portuguesa e espanhola, cujos reinos foram invadidos pelas tropas francesas. ${ }^{134}$ A nação deve ser entendida, então, como um território imperial que abrangia quatro continentes. Assim, O Patriota expressava era uma concepção ativa e utilitária de patriotismo, oriunda da Ilustração e do enciclopedismo. O patriota era o indivíduo útil ao Estado e que, com isso, demonstrava a sua lealdade e proximidade com o monarca na defesa do governo e das suas instituições. ${ }^{135}$ Dessa forma, ao contrário do que pode parecer à primeira vista, ao intitular o seu periódico como $O$ Patriota, Araújo Guimarães não estava, explicitamente ou implicitamente, expressando um incipiente nacionalismo brasileiro, que se opunha ao Império Português. Essa concepção de patriotismo é encontrada, por exemplo, como quando Jacinto José da Silva Quintão, na sua memória sobre a cochonilha publicada no periódico, afirma os objetivos que o animavam a escrever aquele

\footnotetext{
133 Ibid.

134 Significado se sobrepunha a outro, de cunho mais revolucionário, surgido no âmbito da politização da esfera pública que marcaria o fim dos antigos regimes, onde a palavra patriota e a identidade política correspondente estavam carregadas de um sentido militante.

${ }^{135}$ MOREL, op. cit., p. 19 a 24.
} 
trabalho:

Animado e esperançado nos desejos que tenho de ser útil a vós e ao Estado, vou participar-vos as verdadeiras luzes que tenho adquirido sobre este objeto, dandovos o método de a propagardes para que sejais útil a vós mesmos, e promovais a felicidade da minha e vossa pátria e da Nação inteira. ${ }^{136}$

A trajetória política de Jacinto José da Silva Quintão, aliás, era controversa como a de Manuel Arruda da Câmara. Natural do Rio de Janeiro, Quintão era bacharel em medicina pela Universidade de Montpellier (1778), exercendo a medicina na sua cidade natal. Participou efetivamente das reuniões da Sociedade Literária do Rio de Janeiro. Sociedade científica surgida em 1786 sob a proteção do Vice-Rei D. Luís de Vasconcelos e Sousa. A Sociedade funcionou até 1790, quando Luís de Vasconcelos foi substituído pelo Conde de Resende, um vice-rei pouco "simpático às elocubrações científicas", nas palavras de Lorelai Kury e Oswaldo Munteal. ${ }^{137}$ Em 1794, o Conde de Resende proibiu definitivamente as reuniões da Sociedade Literária, que havia retomado as suas atividades, e instaurou uma devassa contra seus membros, acusados de professarem contra a religião e a monarquia e a favor da República francesa. Silva Quintão, o poeta Manoel da Silva Alvarenga e o bacharel Mariano José Pereira da Fonseca ficaram presos por três anos, sendo postos em liberdade graças à intervenção da rainha $\mathrm{D}$. Maria I, por intermédio de D. Rodrigo de Sousa Coutinho. ${ }^{138}$ Kury e Munteal argumentam que a intervenção do Ministro a favor dos acusados se justifica, pois

os membros da Sociedade Literária do Rio de Janeiro faziam parte pessoalmente do grupo ilustrado ao qual pertenciam Sousa Coutinho, Vandelli, e tantos outros que compartilhavam dos ideais de desenvolvimento do comércio, das artes e da agricultura no Reino e em suas conquistas. ${ }^{139}$

Na Introdução da sua Memória sobre a cochonilha, Silva Quintão se refere aos trabalhos da Sociedade Literária, atribuindo a ela a descoberta do anil e da cochonilha e também como forma de desagravo contra as acusações e a devassa por ela sofrida:

\footnotetext{
${ }^{136}$ QUINTÃO, J. J. da S. Memória sobre a cochonilha e o método de a propagar, oferecida aos lavradores brasileiros por um patriota zeloso e amante da felicidade pública. O Patriota: Jornal literário, político e mercantil. Rio de Janeiro: Na Impressão Régia, $\mathrm{n}^{\circ}$ 4, outubro de 1813. p. 12.

${ }^{137}$ KURY, L. B. \& MUNTEAL FILHO, O. Cultura científica e sociabilidade intelectual no Brasil setecentista: um estudo acerca da Sociedade Literária do Rio de Janeiro, p. 112.

${ }^{138}$ A respeito da devassa contra a Sociedade Literária do Rio de Janeiro ver também o livro de Afonso Carlos Marques dos Santos, de 1992, No Rascunho da Nação: Inconfidência no Rio de Janeiro.

${ }^{139}$ KURY \& MUNTEAL, op. cit., p. 112.
} 
O Excelentíssimo Marquês do Lavradio, no segundo ano do seu Vice-reinado, movido por alguns gênios literatos amantes do bem público, estabeleceu nesta capital uma sociedade denominada - Sociedade Literária do Rio de Janeiro -: e bem que estabelecida sem aqueles fundamentos necessários para a sua conservação, contudo bastou-lhe o zelo e atividade do seu autor para ela não só continuar no exercício para que tinha sido criada, de promover a felicidade pública por meio da agricultura, como também de desenvolver idéias profícuas adormecidas em cabeças que pareciam obtusas e pouco científicas. (...) Com a mudança e retirada daquele Marquês, afrouxaram-se as forças da recém-nascida Sociedade, e indo já a ponto de extinguir-se, apareceram novos sócios com maior zelo e amor do bem público, que procurando ao novo Vice-Rei, o Excelentíssimo Vasconcellos, fizeram-lhe conhecer a utilidade daquele estabelecimento. Ao que ele anuiu, como era de esperar do homem de letras. (...) Ali não só se tratava da Filosofia, Matemática, Astronomia, modos de facilitar os trabalhos do agricultor, fazendo-lhe conhecer a qualidade do terreno para não ser infrutuosa a sua lavoura, como se tratava da saúde pública entre os médicos e cirurgiões peritos e dignos de serem membros daquela sociedade. (...) E quando esta se achava envolta em trabalho de mera utilidade pública, chegou a mudança e retirada do Excelentíssimo Vasconcellos. O novo vice-rei, o Excelentíssimo Conde de Rezende, a extinguiu por motivos alheios deste lugar, ficando muitos projetos úteis em esquecimento: mas eu vou publicar um deles por me parecer de grande utilidade. ${ }^{140}$

Alguns autores pretendem ver na trajetória de Silva Quintão, assim como na de Arruda da Câmara, o nascimento de um sentimento de nacionalidade americana e, até mesmo, projetos republicanos. Segundo a argumentação desses autores, esse novo sentimento de nacionalidade surgiria dos esforços desses letrados de conhecimento da realidade americana tendo em vista a adaptação do conhecimento científico a essa realidade, e levaria ao desejo de emancipação do Brasil frente às outras partes do Império Português. Argumentação que me parece um desenvolvimento do insight de Oliveira Lima de que a emancipação intelectual da colônia, com a criação no Rio de Janeiro de diversos estabelecimentos científicos por D. João, seria a base da sua emancipação política:

O incontestável progresso material e moral da colônia, praticamente emancipada desde que a corte portuguesa nela se fixara (...) fora gradualmente produzindo um efeito inesperado (...): o de distanciar espiritual e politicamente os súditos dos dois continentes, tanto ou mais quanto os havia distanciado a natureza. ${ }^{141}$

Maria Rachel Fróes da Fonseca, por exemplo, apesar de reconhecer que o termo pátria significava, nos textos daqueles letrados, uma referência ao local de nascimento, enquanto a ideia de nação relacionava-se à metrópole portuguesa, afirma que a utilização das expressões nação e pátria apontavam para um

\footnotetext{
${ }^{140}$ QUINTÃO, op. cit., p. 12/13.

${ }^{141}$ LIMA, O. D. João VI no Brasil. p. 172.
} 
progressivo processo de afastamento em relação à metrópole, por meio do qual aqueles homens já não se viam mais como portugueses propriamente:

A ideia de "pátria" presente nas páginas de "O Patriota" e nas trajetórias de Arruda da Câmara e de Jacinto Quintão, embora ainda incipiente se compreendida em termos do significado que alcançará posteriormente, já esboçava a defesa e o reconhecimento das qualidades da terra brasileira, os valores de pertencimento àquele território no qual habitavam, como um embrião da conscientização do ser americano. E, neste sentido, pontuamos a correlação da prática científica e o processo de emancipação em construção que, em um momento posterior, alcançará outro norte, a independência política propriamente dita. (...) Suas idéias científicas permitiam a construção dos fundamentos para o conhecimento e afirmação dos recursos e valores (humanos e econômicos) próprios de sua realidade, e representavam os elementos desencadeadores deste processo de distanciamento. ${ }^{142}$

Por trás dessa argumentação me parece haver uma interpretação incorreta da utilização dos conceitos de nação e pátria por parte dos letrados portugueses de finais do século XVIII e início do XIX. Em uma perspectiva oposta, Marco Morel chama a atenção para a presença maciça de um grupo de letrados baianos na Impressão Régia do Rio de Janeiro, que se destacavam pela quantidade de artigos que publicaram em $O$ Patriota, e que expressaria o alinhamento das elites culturais, políticas e administrativas da Bahia com o governo central do Império, no Rio de Janeiro. O que ajudaria a explicar a ausência de repercussão importante dos movimentos de 1817 e 1824 nesta província:

\begin{abstract}
Pode-se dizer, pelo tipo de inserção deste grupo de homens de letras, que os baianos presentes nas páginas de $\mathrm{O}$ Patriota como que preteriram sua pátria (local de nascimento) em favor da Pátria (espaço de atuação intelectual e política) e da nação portuguesa, que incluía a América. Eles não buscavam, em 1813, um corpo político baiano autônomo e até independente de Portugal e das demais capitanias americanas (...), mas sim uma inserção cada vez mais enraizada da Bahia dentro da nação portuguesa - ou luso-brasileira, como querem alguns -, pautando sua atuação política, científica e intelectual pelo viés institucional, pela ampliação de poderes no interior do Estado, não buscando subvertê-lo, mas sim reformá-lo. ${ }^{143}$
\end{abstract}

O grupo incluía, além de Manuel Ferreira de Araújo Guimarães, José da

142 FONSECA, M. R. F. da. Luzes das Ciências na Corte Americana: Observações sobre o periódico "O Patriota”, p. 101. Em seu artigo, a autora busca recuperar os antecedentes da história da emancipação do Brasil pelo estudo da forma pela qual um grupo social específico, o dos homens de ciência, compreendeu o papel do conhecimento científico no direcionamento da sociedade, a autora aborda o papel da produção científica divulgada no periódico O Patriota no processo de emancipação cultural e política da colônia: "Acreditamos na ideia de um protagonismo social da ciência na América Latina. Pretendemos assim assinalar o processo através do qual a construção e a afirmação da prática científica (produção científica, trajetória dos cientistas, associações científicas e/ou literárias, periódicos) contribuiu claramente para a tomada de consciência do ser americano. Nesta medida, a ciência adquiriu uma conotação de amplitude social e política". Ibid.

${ }^{143}$ MOREL, op. cit., p. 28. 
Silva Lisboa e seu filho Bento da Silva Lisboa (1793-1864), o brigadeiro Domingos Alves Branco Moniz Barreto (1748-1831) e Domingos Borges de Barros (1780-1855), formado em direito em Coimbra (1800-1804), que enviava os seus textos de Paris. É significativo o número de contribuições deste último no periódico. É possível encontrar trabalhos seus em diversas categorias como Hidráulica (Memória sobre o meio de desaguar ou esgotar as terras inundadas ou enxarcadas, por método fácil e pouco dispendioso e Notícia sobre o meio que se seguiu no esgotamento de um pântano), Botânica e Agricultura (Memória sobre a plantação e fabrico do urucu; Noções sobre a cultura e fabrico do anil e análise desta matéria colorante e do pastel; Memória sobre o café, sua história, cultura e amanhos; Meios empregados pelos chins para a propagação das árvores frutíferas), Artes (Notícia acerca dos vários carros de transporte, e particularmente dos que os franceses chamam Haquet, invenção do célebre Pascal e Branqueação da cera) e Literatura com a publicação de poesias próprias e traduções de poetas clássicos. O ponto em comum entre todas as memórias científicas de Barros é o desejo de ser útil à pátria e aos compatriotas. Como ele procura deixar claro no final da sua memória sobre o café:

E quando este escrito, filho de uma pena pobre de idéias e só rica de patriotismo, não causar outro bem ao menos anunciando as obras dos autores que têm escrito sobre o café, ao mesmo tempo que incita a curiosidade, encaminha-a para se poder satisfazer, o que é sempre um bem. ${ }^{144}$

Barros pretendia ser útil também pelo estímulo à emulação, como afirma na sua Notícia sobre carros de transporte fabricados na França. Ao descrever um determinado tipo de carro afirma que, convencido da sua utilidade, havia dirigido a construção de um no Rio de Janeiro e esperava que outros também o fizessem, utilizando a sua máquina como modelo. Esta ação sintetizava o sentido do seu patriotismo:

Sem haver quem abra o exemplo, vem a ser inúteis quantas memórias se escrevem, ainda que sejam de conhecida utilidade. Tanto pode o hábito nos homens afincados à rotina! Todavia, temos tantos lavradores distintos que é de esperar que as melhorações em todos os gêneros facilmente se propaguem. (...) espero que a

\footnotetext{
${ }^{144}$ BARROS, D. B. de. Memória sobre o café, sua história, cultura e amanhos. O Patriota Jornal literário, político e mercantil. Rio de Janeiro: Na Impressão Régia, $\mathrm{n}^{\circ}$ 2, agosto de 1813. p. 12. Barros assinava as suas contribuições também como B* ou B***.
} 
minha lembrança seja proveitosa e seguida pelos meus compatriotas, a bem dos quais consagrei, e consagrarei sempre, os meus estudos e desvelos. ${ }^{145}$

Sérgio Alcides, por sua vez, analisa a participação poética de Domingos Borges de Barros no periódico, ressaltando a relação existente entre as características formais da sua produção poética e o sentido patriótico da sua contribuição. Segundo o autor, o neoclassicismo de Barros está em relação de coerência com a sua preocupação patriótica, que não é nacional mesmo que, por vezes, a pátria corresponda em seus textos à Bahia, mas antes a participação em um projeto imperial, "com o qual ele se propunha contribuir da maneira mais útil". ${ }^{146}$ Conclui o autor que as colaborações poéticas de Borges de Barros em $O$ Patriota são reveladoras "das relações e anseios coletivos de toda uma geração da elite letrada luso-brasileira, em especial aquela oriunda da grande propriedade agrícola". 147

Lorelai Kury, por sua vez, atenta para o fato de que uma das linhas editoriais mais visíveis de $O$ Patriota foi a tentativa de constituir um corpus referencial de textos sobre o Brasil, organizando metodicamente os conhecimentos já estabelecidos e estimulando o debate sobre a sua especificidade. Sem, no entanto, se refletir no surgimento de um esboço de nacionalidade outro que aquele implícito na forma como era compreendido o conceito pátria e seus derivados à época. Referindo-se à produção de Domingos Borges de Barros, Kury afirma que o ideal de herói patriota, longe de evocar desempenhos incomuns em batalhas ou mesmo a escrita de poemas e epopéias gloriosas, deveria basear-se no critério da utilidade técnica e científica. ${ }^{148} \mathrm{O}$ que afirma o próprio Barros no final da primeira parte da sua Memória sobre o café (dividida e publicada em três partes):

Não sei porque gastamos tanto tempo e páginas em saber quem comandou em tal batalha, quantos mortos se acharam no campo; e nenhum em transmitir ao futuro os nomes daqueles a quem devemos tal ou tal planta. Por ventura interessa mais saber-

\footnotetext{
${ }^{145}$ BARROS, D. B. de. Notícia acerca dos vários carros de transporte, e particularmente dos que os franceses chamam Haquet, invenção do célebre Pascal. O Patriota Jornal literário, político e mercantil. Rio de Janeiro: Na Impressão Régia, $\mathrm{n}^{\circ}$ 4, abril de 1813. p. 81.

${ }^{146}$ ALCIDES, S. O Lado B do Neoclassicismo Luso-brasileiro: patriotismo e poesia no "poderoso império", p. 133.

${ }^{147}$ Ibid., p. 134.

${ }^{148}$ KURY, L. Descrever a pátria, difundir o saber, p. 146
} 
se quem contribui para a destruição do que para a conservação da espécie humana? ${ }^{149}$

Dessa forma, a produção de $O$ Patriota parece apontar para a sua participação no projeto político reformista ilustrado de reerguimento do Império português a partir da exploração dos recursos naturais da sua principal colônia, como sintetizado no programa de reformas de D. Rodrigo de Sousa Coutinho. E os letrados que participavam da sua edição, tendo o próprio Manuel Ferreira de Araújo Guimarães à frente, aparecem antes como herdeiros do patrimônio intelectual ilustrado português e construtores desse projeto a partir de 1808. A filiação entre o projeto editorial de $O$ Patriota e das tipografias criadas no final do século anterior em Portugal sob o comando de Sousa Coutinho é, aliás, ressaltada por diversos autores.

Segundo Lorelai Kury, a diversidade temática dos artigos de O Patriota, fruto do caráter enciclopédico do trabalho dos seus colaboradores, e a preocupação didática na forma da abordagem, ligam o periódico ao ambiente intelectual ilustrado europeu. ${ }^{150}$ Nesse sentido, O Patriota pode ser considerado como uma continuação da política editorial promovida por Frei Mariano José da Conceição Veloso, na Tipografia do Arco do Cego. Como explica a autora, boa parte dos colaboradores do periódico escreve sobre diversos assuntos e não se detêm em áreas científicas ou técnicas específicas. Ao contrário do que aconteceria ao longo do século XIX, quando se assiste à consolidação paulatina de um ideal científico que, apesar de valorizar o aspecto utilitário do conhecimento, passa a enfatizar as especializações, estabelecendo um maior distanciamento entre atividade científica e debate político:

Essa característica, típica do período das Luzes, sela a vinculação de $O$ Patriota a um ambiente cultural e científico ainda distinto da especialização, a qual começa a se afirmar de forma duradoura em centros europeus como a Inglaterra e a França. ${ }^{151}$

\footnotetext{
${ }^{149}$ BARROS, D. B. de. Memória sobre o café, sua história, cultura e amanhos. O Patriota Jornal literário, político e mercantil.. Rio de Janeiro: Na Impressão Régia, nº 5, maio de 1813. p. 12.

${ }^{150}$ Da comparação entre os índices dos exemplares e o Índice Geral de O Patriota, publicado no último número do periódico (Nov./Dez. 1814), pode-se identificar 5 seções temáticas: Ciências (subdividida em Matemática, Navegação e Hidrografia, Hidráulica, Botânica e Agricultura, Química, Medicina e Mineralogia) Artes, Literatura (subdividida em Gramática, Eloquência e Poesia), História e Política (subdividida em Estatística e Comércio). Havia também seções mais ou menos fixas como Necrologia, Correspondência, Obras Publicadas nesta Corte, Observações Meteorológicas, Estado da Atmosfera e Continuação do estado da Atmosfera.

${ }^{151}$ KURY, op. cit., p. 143. Manoel Salgado Guimarães também ressalta a filiação entre $O$ Patriota e a Tipografia do Arco do Cego: "Cotejando-se o índice de publicações que saíram do prelo da Casa Literária do Arco do Cego com o que foi publicado nas páginas de O Patriota, pode-se
} 
Essa relação fica ainda mais clara se atentamos para o fato de que não é difícil encontrar nas páginas do periódico memórias já antes publicadas pela Tipografia do Arco do Cego, entre as quais a já citada Memória sobre a cultura dos algodoeiros, de Arruda da Câmara. Assim como relatos de viagem produzidos no final do século anterior pelos discípulos de Vandelli, como o Extrato da viagem que fez ao sertão de Benguela no ano de 1785 o bacharel Joaquim José da Silva e as Notícias sobre Cabo Negro, extraídas dos fragmentos da viagem do doutor Joaquim José da Silva, que são parte do diário da viagem de dois anos que aquele naturalista realizou entre 1785 e 1787 pelos sertões de Angola; ou o Ensaio político sobre as ilhas de Cabo Verde para servir de plano à História Filosófica das mesmas, de João da Silva Feijó, que tratava das observações feitas por ele quando de sua estada naquelas ilhas entre os anos de 1783 e 1797. É possível encontrar no periódico, também, memórias do final do século XVII e início do XVIII, como é o caso da Prática de Alexandre de Gusmão entrando na Academia Real de História Portuguesa, em o dia 13 de março de 1732, ou do Discurso do doutor Duarte Ribeiro de Macedo sobre a introdução das artes no Reino, que escreveu sendo enviado na corte de Paris no ano de 1675.

Mais um aspecto a ressaltar a filiação entre o projeto editorial de $O$ Patriota e a ilustração portuguesa é o fato dos artigos publicados, principalmente, nas seções de Ciências e Artes do periódico apresentarem a mesma preocupação com a aplicação prática das disciplinas abordadas. São memórias essencialmente técnicas, que abordam as minúcias do modo de produção das culturas, visando otimizar o seu aproveitamento econômico, corrigindo os erros perpetuados por uma prática baseada exclusivamente na empiria. ${ }^{152}$ Como chama a atenção Lorelai Kury, "a ciência que se quer patriótica é indissociável de seus desdobramentos

constatar uma grande proximidade de temas e preocupações presentes em ambos os projetos editoriais". GUIMARÃES, op. cit., p. 72.

${ }^{152}$ É o que caracteriza, por exemplo, os citados trabalhos de Domingos Borges de Barros sobre a cultura e fabrico do urucu, do anil ou do café. A respeito da cultura do café, por exemplo, afirma o autor: "É com a colheita que o lavrador vê pagas suas fadigas e despesas. E a do café pede que a não principiem sem que o fruto o denote na cor vermelha carregada passando a escura, que indica a sua perfeita madurez. Fujamos de imitar aos habitantes das Maurícias que, pelo temor da perda que os ratos e outros animais os fazem sofrer, colhem antes do tempo, vindo a perder em qualidade e peso, a aumentar o trabalho de separação ou escolha do grão, pois que vem de mistura muito miúdo e inferior com o bom” (BARROS, D. B. de. Memória sobre o café, sua história, cultura e amanhos. O Patriota. $\mathrm{n}^{\circ}$ 2, agosto de 1813. p. 3). 
úteis". ${ }^{153}$ Assim sendo, afirma a autora que o periódico pretendia, assim como as publicações do Arco do Cego, formar leitores, escritores e também agricultores:

$O$ Patriota pretendeu influenciar a própria formação dos homens de letras locais, tanto na qualidade de leitores quanto na de escritores. Seu didatismo é também manifesto em sua maneira de fundar uma síntese do que era sabido sobre as terras brasileiras. (...) Assim, é nessa confluência entre a construção de uma singularidade brasileira, inserida no universo imperial português, e os modelos científicos dos centros europeus que se constitui uma das principais manifestações do iluminismo luso-americano. ${ }^{154}$

Porém, como ressalta aquela autora, no Brasil, a efetiva atuação dos agricultores ilustrados não foi nem de longe tão expressiva quanto nos centros europeus e em algumas outras colônias. Os próprios autores que se ocupavam de assuntos agrícolas no periódico e eram, ao mesmo tempo, donos de propriedades escravistas, não consta serem afeitos à experimentação agrícola, como era o caso de Domingos Borges de Barros. Seus relatos não parecem ser frutos de experiência própria e sim da observação de procedimentos alheios, feita na França onde vivia. É o caso da Notícia sobre o meio que se seguiu no esgotamento de um pântano, onde Barros descreve um trabalho de esgotamento realizado em SaintDenis, nas proximidades de Paris, por um certo Charpentier; ou da Memória sobre a plantação e fabrico do игиси, em que Barros reproduz um trabalho escrito por um certo Mr. Leblond, cultivador de urucu em Caiena. Apesar de, em pelo menos uma passagem da sua Memória sobre o café, Barros criticar os autores exclusivamente teóricos ou aqueles que pretendiam lançar "leis gerais" embasados no conhecimento de apenas uma realidade. ${ }^{155} \mathrm{~A}$ única exceção digna de nota parece ter sido Manuel Arruda da Câmara, considerado pela autora como o exemplo mais próximo do agricultor ilustrado. Como afirmou Silva Lisboa na

\footnotetext{
${ }^{153}$ KURY, op. cit., p. 142. A união mesma dos trabalhos de Botânica e Agricultura em uma única seção do periódico, duas áreas de conhecimento que nos dias atuais têm os seus campos de atuação bem demarcados e que não se confundem, já aponta para aquela preocupação pragmática que caracterizou a Ilustração portuguesa. Como chama a atenção Lorelai Kury, até mesmo em diversos trabalhos da seção História, relatos de viagem que descrevem práticas econômicas de diferentes províncias, é abordada a questão da racionalização da produção agrícola.

${ }_{155}^{154}$ Ibid., p. 142.

155 "Por isso que autores há que facilmente publicam o que, sem o cunho da experiência, só existe em suas visões; outros que, apesar de falarem com a experiência, variando as circunstâncias em que se achavam das em que nos achamos, servindo ela ali de farol, aqui pode iludir. Cumpre, portanto, ler mas com escrúpulo. E nunca, porém, praticar o que colhemos da leitura sem que, com estudo do sítio e mais particularidades do caso em que nos achamos, possamos decidir se estamos na mesma circunstância que eles, a fim de ver se os devemos seguir em tudo, ou que desconto é mister dar-lhes. Grande mestra é a teoria, mas deve dar as mãos às lições de prática" (BARROS, D. B. de. Memória sobre o café, sua história, cultura e amanhos. O Patriota Jornal literário, político e mercantil. $\mathrm{n}^{\circ} 6$, junho de 1813. p. 43).
} 
carta que remeteu a Domenico Vandelli em 1781, referindo-se particularmente ao cultivo da cana de açúcar:

Este nosso século é o século da agricultura. Todo o mundo escreveu sobre isso, formando-se planos de gabinete talvez sem se ter uma só vez remexido a terra. A agricultura, porém, é mais fácil e mais bonita de escrever do que de executar. Prescindindo do rude, do insuportável trabalho da manobra, a lavoura da cana, não obstante as suas vantagens, é muito detrimentora e cheia de mil incômodos. ${ }^{156}$

Apesar das suas pretensões de ser útil à produção agrícola do Brasil e, consequentemente, à economia do Império, a publicação de $O$ Patriota durou apenas dois anos. Sendo que, no segundo ano a sua periodicidade passou de mensal a bimestral. A justificativa para tal mudança pode ser encontrada na análise da lista de subscritores do periódico. Como os seus custos não contavam com a contribuição expressa do governo, a sua edição dependia, do ponto de vista financeiro, exclusivamente das assinaturas. Segundo Tânia Bessone, a primeira subscrição contava com 153 assinantes, enquanto na segunda o número de assinantes caiu para $104 .{ }^{157}$ Assim sendo, O Patriota parece não ter despertado a atenção esperada do reduzido público leitor da colônia, a ponto de garantir a sua continuidade. Talvez por haver alguns descompassos entre o discurso da inovação agrícola propagado pelo periódico e o latifúndio escravista brasileiro, que justificaria o desinteresse dos agricultores pela inovação e aperfeiçoamento técnicos. Em uma memória sobre a construção de um novo tipo de fornalhas para a fabricação de açúcar, o autor se queixa dos plantadores aferrados a antigos hábitos que, depois de terem construído as fornalhas de forma incorreta, creditavam seu fracasso às próprias fornalhas e não à sua incompetência em fabricá-las:

Mas, por lástima e infelicidade, é tal a ignorância e a obstinação da maior parte deles, que habituados a viver nas trevas mais espessas, ainda quando o sol está no seu Zenith, fecham de propósito os olhos para continuarem a gozar da triste escuridão em que nasceram. ${ }^{158}$

Tereza Cristina Kirschner afirma, referindo-se à experiência de Silva Lisboa

\footnotetext{
${ }^{156}$ LISBOA, op. cit., p. 501.

${ }^{157}$ FERREIRA, T. M. T. B. da C. Redatores, livros e leitores em O Patriota, p. 58/59. O periódico contou com três subscrições. Duas em 1813 e uma em 1814. Constando de seis edições cada uma. As últimas edições da primeira e segunda subscriçõos (junho e dezembro de 1813) trazem a lista de assinantes do periódico. Não há dados a respeito dos assinantes da terceira subscrição.

${ }^{158}$ Frei Archangelo de Ancona. Memória sobre as novas fornalhas para cozer o açúcar com o bagaço, inventada pelo Doutor Manoel Jacinto de Almeida. O Patriota. n 3, março de 1813, p. $32 / 33)$.
} 
na Mesa de Inspeção da Bahia, que poucas vezes o letrado bahiense teve sucesso na sua tarefa de incentivar a melhoria das técnicas agrícolas e a introdução de novas espécies: "Em geral, os agricultores não se sentiam atraídos pelos livros e folhetos distribuídos. A maioria não manifestava interesse em alterar seus métodos rotineiros ou fazer experiências com o plantio de novas espécies". ${ }^{159}$ Essa falta de interesse dos produtores agrícolas pelas inovações ilustradas do cultivo, teria sido o motivo de os exemplares de $O$ Fazendeiro do Brasil enviados para a colônia ficarem encalhados nas secretarias de governo, sendo devorados pelos bichos, até as sobras serem vendidas como papel velho para fogueteiros já no período do Império, como revela Luiz Carlos Villalta. ${ }^{160}$

$$
* * *
$$

Apesar de alguns autores interpretarem os esforços de arregimentação de letrados nascidos na colônia por parte de D. Rodrigo de Sousa Coutinho como uma iniciativa que visava promover a acomodação de interesses entre as duas principais partes do Império, o projeto de reformas ilustradas do Ministro não se executava sem gerar tensões no interior do Império Português. As controvérsias historiográficas em torno da atuação política de letrados ultramarinos como Manuel Arruda da Câmara e Jacinto José da Silva Quintão apontam para a possibilidade desses homens possuírem projetos políticos próprios que poderiam não se adequar ao projeto de reformas de D. Rodrigo, e para a tensão sempre presente na escolha entre reforma e revolução por parte daqueles letrados. Esses homens eram instados, o tempo todo, a reafirmarem a sua fidelidade à coroa e a sua adesão ao programa de reformas ilustradas da monarquia, sob a pena de se verem acusados de propagarem ideias republicanas e separatistas.

E se, por um lado, houve letrados que, principalmente após a transferência da Corte para o Rio de Janeiro, tiveram a oportunidade de afastar definitivamente toda a desconfiança que pudesse haver sobre a sua fidelidade e o seu patriotismo, participando ativamente da administração do Império, como foi o caso de Mariano José Pereira da Fonseca, que passou da condição de um dos principais acusados

\footnotetext{
${ }^{159}$ KIRSCHNER, op. cit., p. 110.

160 VILlALTA, L. C. Reformismo ilustrado, censura e práticas de leitura: usos do livro na América Portuguesa, p. 223.
} 
na devassa da Sociedade Literária do Rio de Janeiro, juntamente com Silva Quintão, para a condição de Diretor da Junta Administrativa da Impressão Régia, após o estabelecimento da Corte no Rio de Janeiro; por outro lado, casos houve também de outros integrantes da Geração de 1790 que não encontraram o mesmo acolhimento do aparelho burocrático do Império.

Foi o caso, por exemplo, de Hipólito da Costa. Durante a sua estada na América do Norte, entre 1798 e 1800, Hipólito entrou em contato com a maçonaria, fazendo-se maçom, numa loja da Filadélfia. Ao ser enviado por D. Rodrigo para Londres, em 1801, ia também com a missão secreta de obter a proteção junto às lojas inglesas para as suas congêneres portuguesas, onde a maçonaria era criminalizada. Como informa Isabel Lustosa: "Hipólito não obteve sucesso em sua missão junto à Maçonaria inglesa, mas suas atividades já vinham sendo investigadas pelo intendente de polícia Pina Manique e ele foi preso três dias depois de voltar da Inglaterra, em julho de 1802". ${ }^{161}$ Passou cerca de três anos encarcerado em Lisboa, fugindo da prisão em 1805 e estabelecendo-se definitivamente em Londres sob proteção do Duque de Sussex, Augusto Frederico, filho do rei Jorge III e principal figura da maçonaria em seu país, de onde editou, entre 1808 e 1822, o Correio Brasiliense ou Armazém Literário. ${ }^{162}$ À frente do seu periódico, Hipólito não deixou de criticar asperamente a política de Sousa Coutinho na Secretaria dos Negócios Estrangeiros de D. João. Motivo pelo qual chegou a ter a sua circulação proibida no Império Português. ${ }^{163}$ Críticas que revelam as tensões que perpassavam o projeto do reformismo ilustrado português, principalmente após a transferência da Corte portuguesa para o Rio de Janeiro.

$\mathrm{Na}$ edição do Correio Braziliense de junho de 1812, Hipólito comenta a Carta Régia de 4 de dezembro de 1810, que determinava a criação da Academia Real Militar (inaugurada efetivamente em 23 de abril de 1811), criticando a

\footnotetext{
${ }^{161}$ LUSTOSA, op. cit., p. xliii. DIAS, op. cit., p. 122; PAULA, op. cit. p. 14.

${ }^{162}$ Informa Sérgio Goes de Paula que entre 1805 e 1808, Hipólito viveu de traduções comerciais, jornalísticas e literárias e de aulas, dependendo da proteção e amizade do Duque de Sussex. Podendo-se supor, também, que atuou como correspondente de comerciantes portugueses ou mesmo fazendo corretagens. PAULA, op. cit., p. 14.

${ }^{163}$ Apesar de Oliveira Lima afirmar, talvez com certo exagero, que o periódico de Hipólito da Costa era lido, sem rebuço algum, até no próprio Paço: "Não havia, porém, censura que obstasse à franca circulação do Correio Braziliense, onde se criticava com talento toda a marcha da política portuguesa e todos os processos da sua administração. Em Portugal a Regência, mais realista do que o rei, vedara esse periódico, que no Rio era Dom João VI o primeiro a ler com assiduidade". (LIMA, O. D. João VI no Brasil, p. 166). Importante não perder de vista que a intenção de Oliveira Lima nessa passagem é ressaltar o clima de liberdade intelectual em que supostamente se vivia na Corte do Rio de Janeiro.
} 
interferência direta do Estado na organização da instrução pública. Suas críticas à organização curricular da Academia vinham a público por ocasião do falecimento de D. Rodrigo, ocorrido alguns meses antes (em 26 de janeiro de 1812), e tinham na verdade a intenção de criticar a atuação daquele ministro como símbolo da manutenção de uma mentalidade absolutista na condução dos negócios públicos no Império Português:

O Conde de Linhares foi ter à Universidade de Coimbra para estudar leis; e, saindo reprovado no primeiro ano, largou por mão os estudos da Universidade. Logo, ele foi da classe daqueles que desamparam as suas aulas por não poderem com os estudos; mas como as ciências não sejam em Portugal requisitos essenciais para a diplomacia, foi depois nomeado Ministro Plenipontenciário em Turim. Dali foi mandado vir para Secretário da Marinha e Negócios do Ultramar. Logo que chegou a Lisboa, falou imenso sobre a necessidade de que Portugal fosse uma potência marítima. (...) Por estes tempos saiu de Portugal o escritor deste parágrafo, com as mais favoráveis impressões a respeito do ministro, por estas vastas, justas idéias sobre a grandeza da Monarquia Portuguesa, e por toda parte se representava aquele homem como o Regenerador da Monarquia. Voltando depois a Portugal, e examinando o que tinha feito D. Rodrigo de Sousa Coutinho, depois de estar quatro anos ministro da Marinha, achou que nada absolutamente fizera. (...) De tudo quanto prometera, não fez mais do que expedir uma infinidade de leis, alvarás, decretos e avisos que sempre precisavam de outros para sua explicação; de maneira que houve tal cego em Lisboa que enriqueceu só a vender as leis que publicou D. Rodrigo. ${ }^{164}$

A dura crítica de Hipólito da Costa à formação e atuação política de D. Rodrigo pode soar como um exemplo de falta de gratidão, uma vez que ele havia feito parte dos letrados protegidos e patrocinados por aquele Ministro, sendo inclusive indicado por ele para Diretor Literário da Impressão Régia de Lisboa, como ficou dito acima; e soa ainda mais estranha se atentarmos para o fato de que quatro anos antes, Hipólito tecia rasgados elogios a D. Rodrigo, no sexto número do seu periódico, por ocasião da publicação do Decreto de estabelecimento da Imprensa no Rio de Janeiro:

\begin{abstract}
Enquanto o Príncipe Regente de Portugal adornar os lados do seu trono com homens tão beneméritos como D. Rodrigo de Sousa Coutinho, pode estar seguro que o seu nome será estimado pelos estrangeiros e respeitado pelos nacionais. A opinião que o escritor deste parágrafo fazia deste Ministro enquanto viveu em Portugal é a mesma que acha aqui confirmada por todos os homens imparciais, que estão informados dos negócios de Portugal; isto é, que S.A.R. não tem em seu serviço nenhum Ministro, nem mais inteligente, nem mais desinteressado do que D. Rodrigo. ${ }^{165}$
\end{abstract}

\footnotetext{
${ }^{164}$ Correio Braziliense, ${ }^{\circ}$ 49, junho de 1812. p. 708 a 710.

${ }^{165}$ Correio Braziliense, $\mathrm{n}^{\circ}$ 6, novembro de 1808, p. 519/520.
} 
$\mathrm{Na}$ crítica à gestão do Ministro estava implícita uma crítica à própria condução dos negócios de Estado no Império Português. Influenciado pelo que vira na sua viagem à Filadélfia e imerso no ambiente político e intelectual liberal inglês, Hipólito defendia o estabelecimento de instituições mais liberais também no Império Português. ${ }^{166}$ Mas a confiança e entusiasmos expressos em 1808 deram lugar à desconfiança e decepção ao perceber que, quatro anos depois, a gestão do Império continuava pautada por princípios absolutistas. Porém, mesmo perseguido, exilado e marginalizado, Hipólito não defendia o republicanismo ou a separação entre os dois Reinos. Como ressalta Lúcia Bastos, inspirado nos ensinamentos de Montesquieu continuava acreditando, na Monarquia e no projeto de reformas ilustradas, que em Portugal se materializava no modelo do Reino Unido de Portugal, Brasil e Algarves:

\begin{abstract}
Apesar das desavenças com Rodrigo de Sousa Coutinho, Hipólito mostrou-se duplamente fiel àquela geração de 1790, que buscara uma nova configuração para a comunidade portuguesa no mundo. Primeiro, porque conservou (...) o ideal de um Império que combinasse os interesses dos dois lados do Atlântico. Segundo, porque, embora ansiasse por um modelo de sociedade em sintonia com as novas concepções de indivíduo e da política que as Luzes propunham, também se mostrou incapaz de perceber os limites que o peso da tradição ibérica colocava ao projeto que acalentava, limites que resultavam das reduzidas dimensões da elite intelectual e da presença da escravidão. ${ }^{167}$
\end{abstract}

Hipólito não deixou de ser, ele também, assim como José da Silva Lisboa ou Manuel Ferreira de Araújo Guimarães, um daqueles construtores/herdeiros comprometidos com a construção de um novo império português. O que parece ser comprovado com o fato de seu periódico ter morrido, em dezembro de 1822, praticamente ao mesmo tempo em que morria o Reino Unido de Portugal, Brasil e Algarves.

\footnotetext{
${ }^{166}$ Como afirma Isabel Lustosa: "A viagem aos Estados Unidos da América lhe deixaria a mais definitiva impressão e certamente contribuiria para sedimentar nele uma visão de mundo e uma agenda de valores em que a liberdade e os direitos civis tiveram sempre papel central". LUSTOSA, op. cit., p. xli.

${ }^{167}$ NEVES, L. M. B. P. das. Pensamentos vagos sobre o Império do Brasil. p. 511/512.
} 


\section{3}

\section{O Império sob as Luzes da Economia Política}

\section{1.}

\section{E agora, Josés?}

Nenhum outro ramo do pensamento científico de finais do século XVIII e início do XIX expressou melhor a relação intrínseca existente entre o pensamento ilustrado português e a implementação das reformas políticas ilustradas, ressaltando o seu caráter pragmático, do que os trabalhos sobre Economia Política publicados nos dois lados do Atlântico português. A criação da Academia Real das Ciências de Lisboa, no final de 1779, principalmente mas não exclusivamente, abriu amplas possibilidades de reflexão e divulgação de memórias e projetos sobre a organização e desenvolvimento econômico do Império. O resultado dessas reflexões está registrado nas Memórias Econômicas para o adiantamento da agricultura, das artes e da indústria em Portugal e suas conquistas, publicadas pela Academia de Ciências, em 5 tomos, entre 1789 e 1815. Como ressalta Maria de Lourdes Vianna Lyra, as Memórias consistiam em um esforço de sistematização de reflexões que não visavam assegurar somente o desenvolvimento econômico do Império português, mas a sua própria existência política frente ao assédio das outras potências européias. ${ }^{1}$ Pretendiam contribuir na elaboração de um programa de governo com propostas claras de diversificação e incremento da agricultura, emprego de novas técnicas, de exploração e produção de minérios e, sobretudo, sugestões de formas eficientes para preservação do comércio colonial. ${ }^{2}$ Ao analisar as Memórias Econômicas da Academia Real das Ciências de Lisboa, Ana Rosa Cloclet da Silva afirma que, para além da multiplicidade de motivações e temáticas que as compunham,

o que instava em todas elas era a definição de um novo padrão de exploração colonial que, moldando princípios liberais a objetivos reformistas, viabilizasse o delicado equilíbrio entre a reforma do sistema e a preservação de seus próprios limites definidos, em última instância, pela relação Colônia-Metrópole. ${ }^{3}$

\footnotetext{
${ }^{1}$ LYRA, M. de L. V. A Utopia do poderoso império, p. 42.

${ }^{2}$ Ibid., p. 43.

${ }^{3}$ SILVA, A. R. C. da. Inventando a nação: intelectuais ilustrados e estadistas luso-brasileiros na crise do Antigo Regime português 1750-1822, p. 143.
} 
As Memórias Econômicas da Academia contaram com a colaboração de letrados e estadistas de renome, como Domenico Vandelli (Memória sobre a utilidade dos Jardins Botânicos em Portugal; Memória sobre a ferrugem das oliveiras; Memória sobre as minas de ouro do Brasil; Memória sobre os diamantes do Brasil), D. Rodrigo de Sousa Coutinho (Discurso sobre a verdadeira influência das minas e metais preciosos na indústria das nações que as possuem e, em especial da portuguesa) e o bispo José Joaquim da Cunha Azeredo Coutinho (Ensaios econômicos sobre o comércio de Portugal e suas colônias); assim como com as primeiras contribuições de nomes que viriam assumir grande importância no processo de reformas que envolveu o Império português, como Tomás Antônio Vila Nova Portugal, José Bonifácio de Andrada e Silva (Memória sobre a pesca da baleia) e Manuel Ferreira da Câmara Bethencourt (Ensaio de descrição física e econômica da comarca de Ilhéus na América).

O primeiro traço distintivo do pensamento econômico português do final do século XVIII e início do século XIX é uma reabilitação da agricultura como vetor de desenvolvimento econômico. A agricultura era considerada a base das outras atividades econômicas e significava a possibilidade de se ter uma grande população, entendida, ao mesmo tempo, como causa e como conseqüência do progresso agrícola e como expressão da riqueza e prosperidade da monarquia. As Memórias Econômicas da Academia apontavam para um desprezo pelo desenvolvimento da agricultura pela administração pombalina, em detrimento da atenção privilegiada dada ao setor manufatureiro; chamavam a atenção para as precárias condições produtivas do setor agrícola do Reino, em cuja decadência os autores reconheciam causas físicas e causas morais, imputando a estas últimas os principais entraves ao desenvolvimento da economia. ${ }^{4}$

Exemplar desse discurso é a Memória sobre a preferência que em Portugal se deve dar à agricultura sobre as fábricas, de Domenico Vandelli, publicada no primeiro volume das Memórias Econômicas, onde o autor lista como causas

\footnotetext{
${ }^{4}$ Segundo o Dicionário da Língua Portuguesa de Antonio de Moraes Silva, a moral podia ser entendida no início do século XIX como: "A ciência de regular os costumes com respeito ao honesto, virtuoso e decoroso, segundo a ética racional ou revelada". Enquanto uma ação moral seria uma ação "que respeita aos costumes e a sua direção". A moralidade de uma ação estava relacionada à qualidade dela, "isto é, a sua bondade, maldade ou indiferença" (SILVA, A. de M. Dicionário da Língua Portuguesa, p. 317.) Dessa forma, as causas morais da decadência da agricultura em Portugal deviam dizer respeito à ausência de moralidade, ou seja, à sua maldade ou discordância com relação aos costumes e a ética laica ou religiosa.
} 
físicas da decadência da agricultura em Portugal a distribuição do terreno em grandes herdades, a escassez e dispersão da população, a deficiência de caminhos e rios e a falta de meios de cultivo; e como causas morais a falta de instrução dos lavradores, o êxodo para as cidades, as pesadas imposições, nulas isenções e morosas demandas judiciais, o desprezo pelos lavradores e sua situação de miséria. $^{5}$

O comércio aparecia como a outra variável fundamental no processo de desenvolvimento econômico do Reino, ao lado da agricultura. Como explica Ana Rosa Cloclet, tratando-se de uma economia na qual a riqueza provinha essencialmente da esfera da circulação, as Memórias Econômicas da Academia registravam a percepção da urgência de se gerar condições internas para o aproveitamento daquilo que eles consideravam as vantagens naturais de Portugal, especialmente em relação ao seu rico império ultramarino. Era necessário promover-se uma racionalização do comércio colonial de produtos exportados, de modo que se obtivesse maior qualidade e menores custos. Preocupação que era acompanhada pelo objetivo de expansão dos mercados portugueses na Europa e pela preocupação com o desenvolvimento do comércio intercolonial. Porém, o incentivo a esse comércio não deveria, de forma alguma, contestar o lugar hegemônico do Reino como produtor de manufaturas, ao passo que os Domínios permaneceriam essencialmente como fornecedores de matérias-primas, destinadas à dinamização do desenvolvimento metropolitano. ${ }^{6}$

Dessa forma, caracteriza a reflexão dos sócios da Academia de Ciências uma crítica às políticas manufatureiras protecionistas e aos princípios mercantis que as embasavam, consideradas como obstáculo à circulação de mercadorias, e uma defesa da liberdade de comércio. Os letrados da Academia reconheceram o esgotamento das práticas mercantilistas ortodoxas, colocando-se como severos críticos das restrições comerciais, vistas como entraves à circulação de riquezas e como fator de instabilidade política no interior das colônias. Expressavam, porém, os próprios limites dessa percepção, ao buscarem conciliar práticas liberais com a preservação do exclusivo comercial metropolitano. As críticas à política monopolista não traduziam uma oposição à monarquia. Como ressalta Ana Rosa

\footnotetext{
5 Documento citado por José Luís Cardoso (CARDOSO, J. L. O pensamento econômico em Portugal nos finais do século XVIII 1780-1808, p. 57-65).

${ }^{6}$ SILVA, A. R .C. da. op. cit., p. 141 a 150.
} 
Cloclet:

A oposição ao excessivo intervencionismo estatal, à adoção de um protecionismo exacerbado que caracterizara a época pombalina não significou a opção por uma concepção liberal acerca do funcionamento do Estado, tal qual apregoada pela economia política clássica. ${ }^{7}$

José da Silva Lisboa tornou-se o principal porta-voz no Império português das ideias da moderna economia política relativas à liberdade de comércio e à oposição aos monopólios. Idéias que ele defendeu abertamente no seu segundo livro, Princípios de Economia Política, fruto da sua experiência como deputado e secretário da Mesa de Inspeção da Agricultura e Comércio da Bahia, publicado em 1804 em Portugal. Segundo Antonio Penalves Rocha, o livro de Silva Lisboa foi o primeiro "em língua portuguesa que veiculou princípios de economia política clássica". ${ }^{8}$ No seu livro, Silva Lisboa analisa minuciosamente a obra de Adam Smith, principal inspirador dos princípios gerais da sua reflexão econômica. ${ }^{9}$ Lisboa entrou em contato com as teorias de Smith por volta de 1795 , quando teve acesso à tradução para o português do seu mais conhecido livro, Uma investigação sobre a natureza e as causas da riqueza das nações (publicado originalmente, em 1776, na Inglaterra), feita pelo dicionarista Antonio Moraes e Silva.

Afirma Rubens Borba de Moraes, em uma perspectiva nacionalista, que Silva Lisboa "estava convencido de que as teorias do economista inglês fariam a prosperidade do Brasil". ${ }^{10}$ É importante ter em mente, porém, que Silva Lisboa se refere o tempo todo nos seus escritos ao Brasil não como nação independente de Portugal, mas como a nova sede da monarquia portuguesa, uma vez que na conjuntura em que ele escreve, o antigo reino estava na mão dos franceses e, apesar dos esforços encetados para retomá-lo, seu futuro era incerto. Dessa forma, as suas preocupações, assim como a de outros autores que escreviam a partir da América portuguesa naquela conjuntura, estavam voltadas para aquele novo império português que deveria ser criado por D. João na América. O seu horizonte político, porém, era, ainda, o do império lusitano, como ele escreve antes de 1815,

\footnotetext{
${ }^{7}$ Ibid., p. 147.

${ }^{8}$ ROCHA, A. P. A Economia Política na Sociedade Escravista: um estudo dos textos econômicos de Cairu, p. 12

${ }^{9}$ Nove dos treze capítulos do livro são dedicados à exposição da teoria de Smith, incluindo os elogios feitos ao filósofo escocês e a resposta às críticas feitas ao seu sistema.

${ }^{10}$ MORAES, R. B. de. Livros e Bibliotecas no Brasil Colonial, p. 114.
} 
ou do Reino Unido, como ele se refere nas obras escritas após essa data.

Buscando uma delimitação do objeto e objetivos da Economia Política, Silva Lisboa a define como "a ciência e arte de prover às necessidades e comodidades de uma Nação, para o fim da maior opulência dos particulares e do Estado". 11 A partir dessa definição, pode-se afirmar que a Economia Política era entendida como um conhecimento que tinha em vista promover a riqueza e o desenvolvimento das nações, entendidos como elementos constituintes da felicidade social ou do bem comum, a partir da investigação de leis naturais que regulariam a produção, distribuição e acumulação das riquezas. Como afirma Silva Lisboa nos Estudos do Bem Comum e Economia Política:

Como a astronomia inquire as leis que regem as órbitas dos astros no sistema planetário, e a zoonomia investiga as leis da vida dos animais; assim também a Economia Política examina as leis que o autor da Natureza estabeleceu no sistema social ou ordem civil para a subsistência, multiplicação e prosperidade dos homens, desenvolvendo eles as suas qualidades sociais e faculdades do espírito e corpo. ${ }^{12}$

A diferença entre a Economia Política e as ciências naturais residia no fato de que a primeira era considerada também uma arte, como se pode observar da definição proposta por Silva Lisboa. Ou seja, ao mesmo tempo em que se reconhecia a existência de leis naturais (objetivas e constantes) que regeriam os fenômenos econômicos, supunha-se que os estudos de Economia Política deveriam propor preceitos práticos que pudessem prover as necessidades e comodidades dos homens e das nações. Dessa forma, a Economia Política caracterizava-se como uma ciência pragmática, bem de acordo com a orientação do reformismo ilustrado português.

Da mesma forma que a Economia Política era uma ciência regida por leis

\footnotetext{
${ }^{11}$ LISBOA, J. da S. Princípios de Economia Política, p. 115. Nos seus Estudos do Bem Commum e Economia Política, ou sciencia das leis naturais e civis de animar e dirigir a geral indústria, e promover a riqueza nacional, e prosperidade do Estado, publicados pela Impressão Régia do Rio de Janeiro entre 1819 e 1820, Lisboa apresenta uma elaboração mais completa dessa definição: "a ciência da natureza e causas da riqueza das nações, em que se inquirem os retos e eficazes meios de bem se animar e dirigir a indústria geral dos povos, conforme às leis da natureza, para se aumentarem os produtos da terra além dos que a natureza espontaneamente oferece, a fim da progressiva opulência e prosperidade das nações”. LISBOA, J. da S. Estudos do Bem Comum e Economia Política, p. 170.

${ }^{12}$ Ibid., p. 177. Como explica Penalves Rocha, a descoberta de que os fenômenos econômicos eram regidos por leis naturais estava na raiz do nascimento da ciência econômica. Só mediante o reconhecimento da existência de leis tornava-se possível a organização de um conhecimento que as investigasse. Ressalta aquele autor que a idéia, extraída das ciências naturais, de que os fenômenos econômicos eram regidos por leis naturais, promoveu não somente o nascimento da Economia Política como também a elaboração de uma teoria social que na segunda metade do século XIX, recebeu o nome de liberalismo. ROCHA, op. cit., p. 55.
} 
naturais, existiria também uma ordem natural benéfica para a humanidade, que teria sido instituída no mesmo momento da criação do mundo. Essa ordem natural pregava que os homens teriam sido dotados por Deus de aptidões diferenciadas para transformarem, por meio do trabalho, os bens disponíveis e colocá-los à disposição da sociedade, e em razão desta diferença, existente não só entre os homens, mas entre as diferentes regiões e nações, as sociedades humanas não teriam a capacidade de viver isoladamente, posto que nenhum indivíduo ou nação poderia obter sozinho aquilo que precisa para garantir as condições de existência:

A sábia economia do Criador se manifesta claramente na infinita variedade com que diversificou as terras, climas e habilidades, dando a cada país e indivíduo suas produções, vantagens e aptidões particulares; evitando-se assim uma uniformidade desagradável e estabelecendo-se não menos uma dependência e aliança recíproca dos homens e Estados, para mutuamente se ajudarem e desfrutarem os dons da providência. ${ }^{13}$

Porém, essa ordem natural era ignorada pelas leis feitas pelos homens, que tolhiam a sua realização. ${ }^{14}$ Cabia à Economia Política restaurá-la, percebendo os motivos que impediam o seu estabelecimento e aconselhando os soberanos sobre as medidas a serem tomadas para promover a sua implantação. Fazendo corresponder, dessa forma, as leis positivas, criadas pelos homens, às leis naturais imutáveis e constantes que regiam a ordem cósmica, e que deveriam reger também a sociedade civil. ${ }^{15}$ A caracterização das leis econômicas como leis naturais, colocaria a Economia Política no terreno da moral, pois, como afirma

\footnotetext{
${ }^{13}$ LISBOA, J. da S. Princípios de Economia Política, p. 112. A mesma formulação é encontrada também nos Estudos do Bem Comum e Economia Política: "O Autor da Natureza variou os gênios e gostos dos indivíduos para só fazerem bem, e apetecerem racionavelmente certas coisas, no evidente desígnio (...) de multiplicar as repartições da tarefa social e os recíprocos suprimentos e gozos da vida, com prevenção de conflitos, que necessariamente resultam de pretenderem várias pessoas objeto idêntico; igualmente, e ainda em maior razão, parece ter destinado a geral cooperação e comunicação da Espécie Humana em todo o Globo, variando climas, terrenos, produtos e outras vantagens locais, ao mesmo tempo segurando a suave e mútua dependência de todas as regiões. Nenhuma terra dá, nem pode dar, tudo". LISBOA, J. da S. Estudos do Bem Comum e Economia Política, p. 317.

14 "As maravilhas do Criador e as faculdades dos homens se frustram na maior parte (ainda nos mais civilizados países) pelos erros econômicos que destroem o interesse do trabalho e a alumiação dos povos. Vê-se míngua, barbarismo, ódio e deserto onde deveria haver abundância, polimento, cordialidade e povoação". LISBOA, J. da S. Princípios de Economia Política, p. 84.

${ }^{15}$ Como explica Antonio Penalves Rocha, a ordem natural não fora inventada pela Economia Política. No entanto, a Economia Política assumia uma importância capital não só por ter apresentado ao mundo a sua existência, como também por indicar que a obediência às determinações da natureza beneficiaria a humanidade. Ao proclamar a necessidade de obediência às leis naturais, a Economia Política reconhecia que a ordem social concreta havia se apartado da ordem natural, e esta última havia sido substituída por uma verdadeira desordem artificial da sociedade. Cabia à ciência econômica apontar o porquê dessa desordem. ROCHA, op. cit., p. 81 .
} 
Silva Lisboa nos seus Princípios de Economia Política, "sem princípios sólidos de religião e bons costumes, pouco ou nada valem as leis econômicas e civis". ${ }^{16}$ Para o letrado bahiense, o economista seria, portanto, "o auxiliar do moralista":

É, pois, o economista o auxiliar do moralista: este, com o Catecismo Religioso procura sempre atrair todos os homens à prática das virtudes que asseguram a felicidade da vida futura, corrigindo os egoísticos interesses desordenados e as extremas desigualdades das fortunas, com preceitos e exemplos da Lei Evangélica. (...) O Economista, inquirindo os eficazes meios de haver na sociedade sempre abundante cópia do necessário e cômodo à vida, boa distribuição e reto uso dos bens no presente estado de peregrinação, disciplina e prova, contribui para a generalização das virtudes sociais. ${ }^{17}$

Para Silva Lisboa, essa Ordem Natural estabelecia uma divisão natural do trabalho, que seria o primeiro passo do processo de Civilização das sociedades, por demandar a necessidade de comunicação entre os homens. Na Civilização cada homem e cada nação se dedica à produção daquilo que se ajusta melhor às suas faculdades naturais e, em conseqüência, necessita trocar. Ao contrário, no estado de barbárie cada um produz somente aquilo que a vida exige não havendo contato e, portanto, comércio entre os homens: "os selvagens e os povos bárbaros são as crianças da civilização. Por isso pouco trocam e são mais propensos ao roubo. Por essa mesma razão têm pouca divisão de trabalho e, consequentemente, pouca inteligência e riqueza". ${ }^{18}$ Dessa forma, no âmbito da sociabilidade lastreada no comércio acontece o refinamento das relações humanas, inclusive no sentido da maior obediência e sujeição entre vassalo e governante:

A civilização, com riqueza e maneiras doces, vem a ser em todos os países maior onde o sistema de convenção, ajuste e comércio suplanta o sistema de força, injustiça e rapina; ou, ao menos, onde ele predomina e as leis castigam com rigor os forçadores das pessoas e propriedades e mantêm a santidade das convenções de boa fé. ${ }^{19}$

Segundo o pensamento da Economia Política, então, haveria um forte

\footnotetext{
${ }^{16}$ LISBOA, J. da S. Princípios de Economia Política, p. 134.

${ }^{17}$ LISBOA, J. da S. Estudos do bem comum e Economia Política, p. 73. Pedro Meira Monteiro chama a atenção para a proximidade existente entre economia política e moral na forma como as duas eram entendidas no início do século XIX: "Em ambos os casos, discutia-se o agir dos homens, e o acordo entre o seu agir e a própria natureza". MONTEIRO, P. M. Um moralista nos trópicos, p. 28.

${ }^{18}$ LISBOA, J. da S. Estudos do Bem Comum e Economia Política, p. 298. Segundo o sociólogo alemão Norbert Elias, o conceito de Civilização resumiria tudo em que a sociedade ocidental, desde o século XVIII, se julgava superior a sociedades mais antigas ou a sociedades contemporâneas, porém mais primitivas (ou menos civilizadas). Porém, Civilização não seria apenas um estado, mas sobretudo um processo. ELIAS, N. O processo civilizador. v.1, p. 23 a 27.

${ }^{19}$ LISBOA, J. da S. Estudos do Bem Comum e Economia Política, p. 296.
} 
vínculo entre Comércio e Civilização, sendo o primeiro considerado um agente civilizador e a Economia Política a Arte da Civilização. Mas, para exercer a sua função como tal, o comércio deveria estar livre de restrições. Se, por um lado, era dever de um governo sábio zelar para que o trabalho dos cidadãos fosse empregado de forma a suprir as necessidades gerais do povo, visando a menor dependência possível das outras nações, "quanto permitirem as vantagens naturais do próprio território e circunstâncias do país"; ${ }^{20}$ por outro lado, não se deveria, todavia, excluir a franqueza do comércio com aquelas nações, para não se tolher "a emulação dos nacionais" e prover às nações motivos de ciúme e desconfianças que alterassem a harmonia política:

$\mathrm{O}$ amor da independência nacional e o desejo do extenso e geral emprego dos cidadãos não devem precipitar a um governo iluminado ao absurdo e impossível projeto de concentrar no próprio território todos os ramos de indústria e comércio, e menos os daqueles países que têm decisivas vantagens naturais ou adquiridas nesses ramos; e muito menos obstinar-se em consegui-lo à força de proibições importunas ou excessivos direitos de entrada e saída de uns gêneros e extraordinários favores de outros. ${ }^{21}$

A concorrência estrangeira produziria sempre o benéfico efeito de possibilitar a chegada dos produtos ao público com o preço mais barato, o que era favorável à generalidade do povo, ao aumento dos capitais da nação e ao constante estímulo para a emulação daqueles que produzissem ou comerciassem com gêneros semelhantes, afim de aperfeiçoarem a sua obra para excluir do mercado a concorrência estrangeira, sem que para isso fosse necessário recorrer a "alguma odiosa restrição do comércio contra os estrangeiros":

Mostra-se, assim, a teoria como em prática, que a divisão do trabalho é igualmente benéfica aos particulares e às nações; e que a liberdade do comércio amplifica tanto a sólida grandeza e opulência dos Estados (promovendo a perfectibilidade da espécie humana e comodidades sociais), como a contrária polícia arruína os impérios e obsta ao progresso da civilização e filantropia. ${ }^{22}$

Silva Lisboa propõe um princípio geral para a condução da economia dos Estados, que nada mais é do que aquilo que se tornaria o princípio fundamental do liberalismo. A conformidade das leis dos homens à ordem natural só poderia ocorrer mediante a garantia de duas condições - liberdade e propriedade:

\footnotetext{
${ }^{20}$ LISBOA, J. da S. Princípios de Economia Política, p. 122.

${ }^{21}$ Ibid., p. 124.

${ }^{22}$ Ibid., p. 125.
} 
Parece que a mais inocente e melhor economia consiste em se permitir indústria ativa, trabalho discreto, instrução franca, comércio livre e se poder reduzir a este único postulado. Pede-se, como coisa possível, que se deixe a cada indivíduo livremente trabalhar, instruir e dispor em boa fé do fruto de seu trabalho honesto. ${ }^{23}$

José da Silva Lisboa é geralmente caracterizado como o introdutor da economia política no Brasil. Como explica Antonio Penalves Rocha, representações da sua vida e obra surgidas ainda no século XIX, mas que se estenderam ao longo do século XX, construíram sua imagem como construtor do Estado Nacional brasileiro ao mesmo tempo em que o glorificavam como economista. Paralelamente à construção dessa memória, uma historiografia republicana condenou Silva Lisboa como um bajulador da monarquia, defensor do laissez-faire e entreguista das riquezas nacionais. As imagens de Silva Lisboa construídas no século XX certamente traduziam, segundo Penalves Rocha, os conflitos sociais desencadeados pela industrialização brasileira:

Aqueles que escreveram sobre Silva Lisboa adequaram a figura de um homem que viveu entre os fins do século XVIII e início do XIX às posições que eles próprios ocupavam no conflito. Desse modo, a imagem do grande economista referendava a aplicação da doutrina liberal, ou, pelo menos, a aplicação de alguns dos seus princípios e, ao mesmo tempo, combatia o marxismo, atendendo a aspirações de classes dominantes. Inversamente, em nome de aspirações democrático-populares, a imagem de Cairu como um lambe-botas dos reis e do imperialismo desqualificava tanto o personagem histórico e as idéias que ele havia difundido, quanto aqueles que o glorificavam. ${ }^{24}$

Em lugar de uma perspectiva diacrônica, Fernando Novais e José Jobson Arruda consideram mais fértil analisar as idéias econômicas de Silva Lisboa em correlação com os contextos históricos nos quais elas foram formuladas e sobre os quais incidiram, caracterizando-o, antes, como um estadista que intervinha na política econômica. ${ }^{25}$ É por essa ótica que se pretende abordar aqui também a produção de Silva Lisboa sobre Economia Política. Como citado no capítulo anterior, após a mudança da corte para o Rio de Janeiro, Silva Lisboa foi arregimentado para servir em importantes setores da administração do Estado português, sendo nomeado simultaneamente Deputado da Real Junta de Comércio, Agricultura, Fábrica e Navegação, membro da Junta Administrativa da Impressão Régia e Desembargador da Mesa do Desembargo do Paço, o que lhe valia a função de Censor Régio. Não por acaso, Silva Lisboa foi o autor que mais

\footnotetext{
${ }^{23}$ Ibid., p. 102.

${ }^{24}$ ROCHA, A. P., José da Silva Lisboa: Visconde de Cairú, p. 34/35.

${ }^{25}$ NOVAIS, F. A. e ARRUDA, J. J. de A. Prometeus e Atlantes na forja da nação, p. 225/226.
} 
obras publicou pela Impressão Régia do Rio de Janeiro. O amplo acesso à estrutura burocrática de administração do Império lhe permitia a realização do ideal ilustrado português que conjugava a divulgação das suas idéias sobre Economia Política com a execução de uma política econômica para o Império português. Por tudo isso, é possível afirmar que muito antes de poder ser identificado como um construtor do Estado Nacional brasileiro, Silva Lisboa foi um dos construtores do novo império português na América.

Ao mesmo tempo em que José da Silva Lisboa publicava os seus estudos de Economia Política no Rio de Janeiro, um homônimo seu também escrevia os seus na antiga capital do Império: José Acúrsio das Neves (1766-1834), nascido no Casal de Cavaleiros, distrito de Coimbra, guardava interessantes semelhanças biográficas com o letrado bahiense. Bacharel em Direito pela Universidade de Coimbra (1787), desembargador do Desembargo do Paço, Juiz de Fora (1797 a 1799) e depois Corregedor (1799 a 1802) da cidade de Angra, na Ilha dos Açores. Em 1798 Acúrsio enviou o seu primeiro trabalho de Economia Política, intitulado Memória Geográfica, Política e Econômica da Ilha Terceira, para D. Rodrigo de Sousa Coutinho, então Ministro dos Negócios da Marinha e Domínios Ultramarinos, "que muito o apreciou, dirigindo-lhe uma carta bastante elogiativa em que o aconselhava a ler a obra de Adam Smith e o concitava a produzir outros trabalhos", segundo José Calvet de Magalhães. ${ }^{26}$ Animado pelo incentivo do Ministro, Acúrsio publica em 1800 uma Memória Econômica-política sobre a liberdade do comércio dos grãos com a sua aplicação às ilhas dos Açores, onde denuncia os obstáculos monopolistas ao comércio do trigo e defende uma liberdade de comercialização que garantiria um acréscimo da produção agrícola, recorrendo diversas vezes à Riqueza das Nações para consolidar seus argumentos e provando que seguiu o conselho de D. Rodrigo. ${ }^{27}$

Depois de residir por mais de uma década na Ilha Terceira, Acúrsio voltou ao continente, desembarcando em Lisboa em 10 de outubro de 1807, pouco mais de um mês antes do embarque da Família Real portuguesa para a América. Entre 1808 e 1810 ficou afastado das funções públicas. Ganha destaque, então, sua atuação como panfletário e historiador. Dedicou-se à redação de 12 panfletos

\footnotetext{
${ }^{26}$ MAGALHÃES, J. C. de. José Acúrsio das Neves, p. 7/8. O autor reproduz o texto da carta de D. Rodrigo para Acúrsio nas páginas 9 e 10.

${ }^{27}$ CARDOSO, op. cit., p. 92
} 
políticos que viria a intitular de Obras Patrióticas, publicados em Portugal e reeditados no Rio de Janeiro, cujo objetivo era incentivar os portugueses a reagir contra a invasão francesa.

Em 1810 foi eleito sócio da Academia Real das Ciências de Lisboa e nomeado para Desembargador da Relação do Porto (decreto de 15 de junho), Deputado e Secretário da Real Junta do Comércio, Agricultura, Fábricas e Navegação, deputado da direção da Real Fábrica das Sedas do Subúrbio do Rato e obras das Águas Livres ${ }^{28}$ e deputado da junta de liquidação dos fundos da extinta Companhia de Comércio do Grão-Pará e Maranhão. ${ }^{29}$ Foi no exercício dessas funções de administrador fabril, nas quais se manteve sem interrupção até 1821, que Acúrsio das Neves publicou as suas obras de Economia Política mais importantes: Variedades sobre vários objetos relativos às Artes, Comércio e Manufaturas consideradas segundo os princípios da Economia Política (2 volumes, 1814 e 1817) e Memória sobre os meios de melhorar a Indústria Portuguesa, considerada nos seus diferentes ramos (1820). Assim como Silva Lisboa no Rio de Janeiro, Acúrsio escrevia a partir de sua posição de dentro da administração do Estado português, o que certamente lhe garantia uma maior facilidade para a publicação de suas obras no Reino. Mas não no Brasil, pois ao contrário dos seus panfletos políticos, sobre os quais nos deteremos com mais vagar no próximo capítulo, as memórias econômicas de Acúrsio das Neves nunca foram reeditadas pela Impressão Régia do Rio de Janeiro.

As Variedades, primeira obra de fôlego sobre a economia política de Acúrsio das Neves, é em verdade um conjunto de memórias sobre diversos assuntos, que vão desde uma Tradução do capítulo II do tomo $V$ das obras póstumas de Frederico II - Rei da Prússia (volume 1, páginas 55 a 79) até Observações sobre o comércio da Ásia (volume 1, páginas 221 a 270), passando por escritos mais voltados para a realidade portuguesa como Considerações sobre

\footnotetext{
${ }^{28}$ A Real Fábrica de Sedas do Subúrbio do Rato era um empreendimento particular, encampado pela Real Fazenda por decreto de 14 de maio de 1750. Águas Livres era o nome do bairro que se deveria edificar para nele se estabelecerem os fabricantes de seda vinculados à Real Fábrica, de acordo com o decreto do Marquês de Pombal de 4 de março de 1759.

${ }^{29}$ A Companhia de Comércio do Grão-Pará e Maranhão foi criada em 1755 pelo Marquês de Pombal como parte integrante do seu programa de reformas econômicas. A Companhia era uma sociedade anônima que tinha o direito de monopólio, por 20 anos, da exportação e do tráfico de escravos africanos e de produtos importados da Metrópole, como tecidos, vinho, azeite e bacalhau. Em 9 de julho de 1774 o Estado do Maranhão deixou de existir e, com ele, os direitos da Companhia.
} 
a agricultura e manufaturas de Portugal (volume 2, páginas 211 a 267) e Épocas da agricultura e manufaturas em Portugal (volume 2, páginas 269 a 332).

A Memória, por outro lado, é considerada o seu melhor trabalho sobre o tema. Nessa obra pode ser identificado o princípio basilar que fundamenta o seu pensamento econômico: a necessidade do desenvolvimento conjunto dos três setores econômicos (agricultura, manufaturas e comércio), entendidos pelo autor como ramos da indústria, tendo em vista a superação do seu estado de crise, com ênfase no desenvolvimento das manufaturas no Reino. Característica expressa tanto no título quanto na divisão mesma da obra, dividida em três capítulos: Considerações sobre a agricultura, Considerações sobre as manufaturas e Considerações sobre o comércio.

As idéias econômicas de Acúrsio das Neves, assim como as de Silva Lisboa, devem ser analisadas levando-se em conta o contexto histórico no qual elas foram escritas: o de um reino invadido por uma potência estrangeira, abandonado por seu monarca e que perde a sua posição de centro articulador do império ultramarino português. Como explica José Luís Cardoso, a moderna historiografia econômica tem interpretado o último quartel do século XVIII português como um período de expansão e crescimento, euforia ou, pelo menos, relativa prosperidade. Conjuntura que seria substituída, no início do século XIX, por um quadro de crise propiciada seja pela concorrência dos produtos industriais ingleses, que aniquilava as capacidades do mal apetrechado parque manufatureiro do Reino; seja pela abertura dos portos brasileiros, que fazia desabar um dos maiores esteios da prosperidade comercial; seja pelas invasões francesas, que determinavam uma situação de caos na produção e circulação. ${ }^{30} \mathrm{Na}$ sua Memória, Acúrsio confirma esse diagnóstico de uma situação de profunda crise econômica:

Não se pode duvidar da existência dos nossos males, porque os sentimos, e gravíssimos, pois atacam na sua origem as principais fontes da prosperidade pública. Males desta natureza não se curam senão com remédios radicais, e para estes se descobrirem e aplicarem é necessário conhecer a doença nacional; portanto, o primeiro passo deve ser a investigação das causas que nos conduziram à presente crise, procedendo com aquela decente liberdade que permitem os Governos justos, mas não insistindo no passado, senão em quanto for necessário para regular o futuro. ${ }^{31}$

\footnotetext{
${ }^{30}$ CARDOSO, op. cit., p. 37.

${ }^{31}$ NEVES, J. A. das. Memória sobre os meios de melhorar a indústria portuguesa, considerada nos seus diferentes ramos, p. 75/76.
} 
Dessa forma, a investigação das causas que estavam na origem da situação de crise da economia do reino, e a proposta de soluções será o objetivo da Memória de Acúrsio. $\mathrm{O}$ autor coloca em primeiro lugar entre aquelas causas as invasões francesas e, principalmente, o seu mais funesto efeito, a transferência da sede da monarquia para a América:

E como se os males comuns não fossem bastantes para oprimir uma nação já antecipadamente atenuada pela longa série dos acontecimentos que prepararam a catástrofe de 1807, sobrevieram ainda outros não menos agravantes e de trato sucessivo que nos são particulares. O primeiro e o principal é a ausência do Soberano em um país remoto, donde não pode nem conhecer toda a extensão dos nossos sofrimentos, nem enxugar as lágrimas da nossa orfandade. Foi uma medida de absoluta necessidade, que salvou a Monarquia nos seus lances mais arriscados, porém, sepultou a nação em luto; e desde logo podia prever-se que desorganizaria os princípios da administração interna e transtornaria todo o nosso sistema comercial. $^{32}$

A abertura dos portos da América portuguesa, determinada pela Carta Régia de 28 de janeiro de 1808, e a conseqüente perda por Portugal do papel de intermediário do comércio colonial, resultado desse processo, foi para Acúrsio o golpe de misericórdia na economia do Reino, já debilitada pelas três invasões francesas:

Foi o resultado de todas estas causas, que perdido o mercado exclusivo das produções da nossa indústria, que era principalmente no Brasil, e não podendo elas sustentar mesmo em Portugal a concorrência das manufaturas estrangeiras, vimos quase aniquiladas as nossas fábricas, depois de arruinada a nossa agricultura nas terras invadidas, sem ao menos passarmos por algum intervalo que nos preparasse para tão grandes mudanças. ${ }^{33}$

Diante desse quadro, o desenvolvimento da indústria no Reino, pelo fomento conjunto dos seus três ramos, aparecia para Acúrsio como única saída para a crise. Como explica Antonio Almodovar, segundo o pensamento de Acúrsio, privilegiando o desenvolvimento particular de um dos três ramos iriam surgir necessária e inevitavelmente bloqueios ao progresso, inerentes a estrangulamentos provocados a vários níveis pelas atividades mais atrasadas: ${ }^{34}$

Segue-se considerar a indústria separadamente em cada um dos três ramos em que ela se divide. Sobre eles devem os Governos estender com igualdade a sua ação benéfica, de modo que nenhum seja mais favorecido que os outros; porque da sua

\footnotetext{
32 Ibid., p. $77 / 78$.

${ }^{33}$ Ibid., p. 79.

${ }^{34}$ ALMODOVAR, A. Texto e contexto: a questão dos privilégios de novo invento em José Acúrsio das Neves, p. 501.
} 
mútua combinação e aumento progressivo é que depende o sistema composto de agricultura, manufaturas e comércio, que faz a prosperidade das nações, e a reação com que obram entre si é a que os eleva gradualmente à sua maior perfeição. ${ }^{35}$

Para viabilizar o desenvolvimento da indústria no Reino, Acúrsio considerava como medida indispensável a manutenção dos vínculos comerciais entre Portugal e suas colônias. A sua avaliação das possibilidades econômicas nacionais nunca se desliga da extrema importância do ultramar português, como reconhece na Introdução das suas Variedades:

O Reino de Portugal, que considerado somente pela extensão do seu território nunca poderia ser de alta representação entre as grandes potências da Europa, unido aos estados ultramarinos que fazem parte da monarquia, e considerada a sua posição, as produções e os portos que abraça nas melhores partes do mundo, forma um corpo que para ser respeitável ao de fora, e rico no interior, não precisa senão de indústria dirigida por bons princípios. ${ }^{36}$

Em particular, Acúrsio via como saída para a crise econômica do Reino a manutenção dos vínculos comerciais com o Brasil, para o qual prognostica um futuro próspero sob os efeitos da política econômica de D. João:

O Senhor Rei D. João VI, acomodando-se aos acontecimentos políticos e aproveitando-se das vantagens da sua situação geográfica, lhe tem começado uma nova era, que promete um futuro mui brilhante. Colocado longe da Europa, não podendo nem ser facilmente atacado pelas potências do antigo continente, nem envolvido nas suas revoluções, tão rico e fértil no interior, com tantos portos e tantos rios navegáveis, olhando para ambos os hemisférios, a que ponto de prosperidade não pode chegar o Brasil debaixo de um bom governo, quando tiver uma povoação industriosa proporcionada à sua extensão? ${ }^{37}$

Mas, a prosperidade do Brasil propiciada pelo seu livre comércio poderia beneficiar também a economia de Portugal, desde que não se perdesse o nexo comercial entre as duas partes do Império. Caso contrário, o futuro de Portugal, separado do seu ultramar, era incerto:

O Brasil, comerciando livre, crescerá sem dúvida em prosperidade, e quanto mais crescer mais vinha e manufaturas consumirá e maiores vantagens oferecerá a Portugal; contanto que os dois países permaneçam ligados entre si por meio de laços recíprocos debaixo de um Governo comum, justo e sábio, que estenda com igualdade as suas vistas protetoras sobre todas as partes do império. (...) Se, pelo contrário, viesse a faltar-lhe o centro de união, desorganizado o corpo da Monarquia, cada um dos seus membros perderia todo o vigor, recebendo como

\footnotetext{
${ }^{35}$ NEVES, J. A. das. Memória sobre os meios de melhorar a indústria portuguesa, considerada nos seus diferentes ramos, p. 93.

${ }^{36} \mathrm{NEVES}$, J. A. das. Variedades sobre objetos relativos às artes, comércio e manufaturas, consideradas segundo os princípios da economia política, v.1, p. 3.

${ }^{37}$ Ibid., v.2, p. 298/299.
} 
massa inerte as impressões que quisessem dar-lhe; até chegar o momento em que, desbaratada a herança de nossos avós, o nome português desapareceria, como o fumo, confundido com o de alguma nação mais poderosa. ${ }^{38}$

Acúrsio defendia a manutenção do vínculo político pela intensificação das relações mercantis com as possessões ultramarinas, mas reconhecia a inviabilidade do retorno ao regime de exclusivo comercial anterior a 1808 . $\mathrm{Na}$ impossibilidade de reestabelecer o antigo pacto colonial, Acúrsio propõe a manutenção de Portugal como principal parceiro comercial do Brasil, como não poderia deixar de ser, aliás, sendo os dois reinos pertencentes a uma mesma monarquia. Assim, dois princípios deveriam embasar a política econômica do Reino:

$1^{\circ}$ Chamar outra vez a Portugal, por meios indiretos e de conveniência para ambas as partes o comércio do Brasil; de forma que Portugal seja o principal entreposto dos gêneros coloniais. $2^{\circ}$ Dar preferência no Brasil ao consumo dos vinhos, sal e manufaturas de Portugal; assim como em Portugal se dá preferência ao açúcar, café e mais gêneros do Brasil; devendo considerar-se os dois países como se fossem unidos em território. ${ }^{39}$

Segundo a argumentação de Acúrsio, a manutenção desses vínculos beneficiaria econômica e politicamente também a América portuguesa, enquanto essa não tivesse forças para desenvolver sozinha a sua manufatura e agricultura. Além do mais, era um dever moral do então Reino do Brasil não romper esses vínculos com sua outrora metrópole:

Tem o Brasil todas as proporções para vir a ser com o andar dos tempos um grande império; mas por ora é um país novo, sem fábricas e com uma agricultura limitada, que precisa dos socorros da mãe-pátria, tanto na paz como na guerra; sob pena de ficar em uma eterna infância ou ser esmagado pelo primeiro ocupante. (...) Deve, além disso, lembrar-se de que a mãe pátria lhe deu a existência. ${ }^{40}$

A reivindicação da presença do monarca aparecia como fundamental ao próprio encaminhamento das reformas concebidas, uma vez que segundo seu pensamento, informado na perspectiva do reformismo ilustrado português, cabia ao Estado a viabilização de qualquer processo de transformação da sociedade, tanto no sentido de incitá-lo, quanto no de garantir sua continuidade e aceitação. Como ressalta Ana Rosa Cloclet, na visão de Acúrsio:

\footnotetext{
${ }^{38}$ NEVES, J. A. das. Memória sobre os meios de melhorar a indústria portuguesa, considerada nos seus diferentes ramos, p. 156.

${ }^{39}$ Ibid., p. 157.

${ }^{40}$ Ibid., p. 154.
} 
A sobrevivência da sociedade dependia da promoção de um conjunto de reformas que, inspiradas numa perspectiva econômica liberal, mas vinculadas a uma concepção absolutista de poder, tinham no Estado, simultaneamente, seu principal agente e inibidor, caso ameaçassem ultrapassar os limites de sua própria conservação. ${ }^{41}$

Ao que tudo indica, os dois Josés conheciam a obra um do outro. Em mais de uma passagem de seus Estudos do Bem Comum, Silva Lisboa cita a obra de Acúrsio das Neves, sempre elogiosa e respeitosamente. Como quando, ao analisar os escritores economistas portugueses contemporâneos, faz uma avaliação das Variedades de Acúrsio:

Depois da paz geral, apareceu a obra do senhor José Acúrsio das Neves, Deputado Secretário da Real Junta do Comércio de Lisboa, à que deu o título de Variedades sobre objetos relativos às artes, comércio e manufaturas, consideradas segundo os princípios de Economia Política. Esta obra é de grande importância pela liberalidade de suas opiniões econômicas, recomendação da que justamente chama imortal obra de Smith, abundância de fatos interessantes que demonstram as causas da preeminência da indústria e riqueza da Inglaterra pelo seu sistema de uso das máquinas e, sobretudo, por desssombrar a nação do terror pânico de perder os estabelecimentos de fábricas para que Portugal tem naturais proporções. ${ }^{42}$

O mesmo já não se pode dizer de Acúrsio com relação a Silva Lisboa, a quem não poupa críticas sempre que o cita. Nas Considerações sobre a agricultura e manufaturas em Portugal, constante do volume 2 das Variedades, Acúrsio critica aquilo que ele via como uma posição anti-industrialista de Lisboa, uma vez que este afirmava que a agricultura era a atividade produtiva mais adequada ao Império Português, como veremos mais adiante:

Não se esperaria que houvesse ainda, no século XIX, quem nos aconselhasse que devemos renunciar à idéia de ter fábricas para nos entregarmos somente à agricultura, como vejo em algumas memórias recentemente publicadas, que contêm aliás outros princípios muito sábios e patrióticos. Não ataco os seus autores, que me parecem animados pelo zelo do bem público, e só iludidos pelos erros dos economistas; mas convém refutar doutrinas perigosas, que entre os povos cultos já se não ouvem sem indignação. ${ }^{43}$

\footnotetext{
${ }^{41}$ SILVA, op. cit., p. 265. A união de uma perspectiva econômica liberal com uma concepção absolutista de poder formaria aquilo que Fernando Pinto Loureiro classifica como o caráter contraditório da vida e da obra de Acúrsio (LOUREIRO, op. cit., p. 22). Mas, como explica José Luís Cardoso, essa contradição é, na verdade, o dilema fundamental que atravessa a sociedade portuguesa de Antigo Regime: "o dilema de uma sociedade em que as reformas econômicas de inspiração liberal se desejam e programam sem a contrapartida de uma modificação da estrutura política do Estado absolutista cuja essência e natureza se procura perpetuar" (CARDOSO, op. cit., p. 209)

${ }^{42}$ LISBOA, J. da S. Estudos do Bem Comum e Economia Política, v.1, p. 112.

${ }^{43}$ NEVES, J. A. das. Variedades sobre objetos relativos às artes, comércio e manufaturas, consideradas segundo os princípios da economia política, v.2, p. 215/216.
} 
Nessa passagem, Acúrsio não cita nominalmente o seu interlocutor, mas parece estar claro a quem estivesse acompanhando as novidades sobre Economia Política publicadas no Império português, a quem ele estava se referindo. Dessa forma, letrados que, a princípio, apresentavam a mesma matriz teórica, fruto que eram do mesmo ambiente ilustrado português e inspirados pelas mesmas leituras, acabavam por defender perspectivas distintas a respeito da política econômica que deveria ser adotada pela Coroa para garantir o desenvolvimento econômico e, consequentemente, a manutenção do Império. E essa divergência não encontra a sua explicação apenas na posição geográfica que cada um ocupava com relação ao móvel centro do Império, ao contrário do que se pode pensar do cotejamento das idéias de Silva Lisboa e Acúrsio das Neves. Pois a perspectiva de Silva Lisboa encontrava seus críticos também entre letrados que, assim como ele, atuavam na Impressão Régia do Rio de Janeiro e, portanto, tinham os seus interesses vinculados à manutenção do aparelho administrativo do Império Português nesse lado do Atlântico, como se verá mais adiante.

O objetivo deste capítulo é chamar a atenção para a importância que a Economia Política assumiu no conjunto da produção da Ilustração portuguesa, devido à discussão que ela propiciava acerca das medidas econômicas necessárias para a recuperação do Império português. O grande volume de memórias sobre o assunto publicado pela Impressão Régia do Rio de Janeiro não apenas aponta para mais um aspecto da continuidade entre o trabalho desta tipografia e suas antecessoras reinóis, caracterizando-a como herdeira das reflexões do ambiente intelectual ilustrado português; mas também para a importância do pensamento econômico no contexto de re-criação do Império português na América, atuando de forma a legitimar as medidas tomas pelo Príncipe Regente. Ao mesmo tempo, procura-se ressaltar como as diferentes perspectivas apresentadas por autores no velho Reino e na nova Corte podem apontar para diferentes projetos de império, assim como para as tensões oriundas da efetivação daquele projeto político.

\section{2.}

\section{O Império do Livre-Comércio}

Segundo Antonio Penalves Rocha, a difusão da Economia Política entre os 
letrados portugueses, entre fins do século XVIII e inícios do XIX, ocorreu sob forte entusiasmo com relação aos benefícios que ela poderia trazer ao império português: "Com efeito, o entusiasmo desses homens para com a ciência foi de tal ordem que passam a impressão de ter descoberto algo parecido com a pedra filosofal". ${ }^{44}$ Rocha chama a atenção para o fato de que, ao contrário do que aconteceu no resto da Europa, no império português o lugar de produção e irradiação das obras de Economia Política foi de dentro do Estado. A sua preocupação pragmática de busca de soluções para a situação de crise política e econômica do Império tornou-a um tema de destaque entre as publicações da Impressão Régia do Rio de Janeiro.

Um dos primeiros livros publicados pela Impressão Régia, ainda em 1808, dedicava-se ao tema e deixava bem explícita essa relação. Tratava-se das Observações sobre o comércio franco no Brasil, de José da Silva Lisboa. ${ }^{45} \mathrm{Em}$ 1808, Silva Lisboa já era reconhecido como especialista na matéria e, por esse mesmo motivo foi nomeado, por Decreto de 23 de fevereiro daquele ano, professor de Economia Política na Corte do Rio de Janeiro. Cargo que, de fato, nunca chegaria a exercer. Rocha chama atenção para o pioneirismo inusitado da medida, uma vez que nessa época não havia curso de Economia Política em lugar algum do mundo. Porém, o mundo teria que esperar até 1819 para conhecer a primeira cátedra de Economia Política, instalada no Conservatório de Artes e Ofícios, na França, sob os cuidados de Jean-Baptiste Say. ${ }^{46}$

$\mathrm{Na}$ falta das aulas, Silva Lisboa se dedicou a tentar divulgar os princípios de Economia Política por meio de suas inúmeras publicações. Além das Observações sobre o comércio franco no Brasil, vieram à luz pela Impressão Régia do Rio de Janeiro, de autoria de José da Silva Lisboa sobre Economia Política: Observações sobre a franqueza da indústria e estabelecimento de fábricas no Brasil (1810), Observações sobre a prosperidade do Estado pelos liberais princípios da nova legislação do Brasil (1810), Razões dos lavradores do vice-reinado de Buenos Aires para a franqueza do comércio com os ingleses, contra a representação de alguns comerciantes e resolução do Governo (1810), Reflexões sobre o comércio de seguros (1810), Refutação das declamações contra o comércio inglês, extraída

\footnotetext{
${ }^{44}$ ROCHA, op. cit., p. 34.

${ }^{45}$ Publicado em três partes. As duas primeiras em 1808 e a terceira em 1809, onde procura responder às objeções feitas às duas partes publicadas anteriormente.

${ }^{46}$ ROCHA, op. cit., p. 1-2.
} 
de escritores eminentes (1810), Extrato das obras políticas e econômicas de Edmund Burke (1812), Memória Econômica sobre a franqueza do comércio dos vinhos do Porto (1812), Ensaio sobre o estabelecimento dos bancos para o progresso da indústria e riqueza nacional (1812) e Estudos do Bem Comum e Economia Política, ou ciência das leis naturais e civis de animar e dirigir a geral indústria e promover a riqueza nacional e prosperidade do Estado (1819/1820). A Impressão Régia do Rio de Janeiro publicou ainda, em 1811, um Compêndio da Obra Riqueza das Nações de Adam Smith, traduzido por Bento da Silva Lisboa, filho de José da Silva Lisboa. E, por um anúncio na edição de 29 de julho de 1812 da Gazeta do Rio de Janeiro, somos informados que os Princípios de Economia Política, publicados em Portugal em 1804, eram vendidos também na nova capital do Império:

\begin{abstract}
Vendem-se na loja de Paulo Martin, o Compendio da Obra da Riqueza das Nações de Adam Smith, em três volumes por 2.400 réis, traduzida do original inglês. Extratos das obras políticas e econômicas do orador inglês Edmund Burke, traduzidas em português, parte $1^{\mathrm{a}}$ e $2^{\mathrm{a}}$, por 1.920 réis, ambas as partes com apêndice. - Comércio Franco no Brasil, 3 vol. por 2.400 réis. - Observações sobre o comércio de Buenos Aires, 2 vol. por 1.600 réis. - Observações sobre a franqueza do comércio no Brasil, 2 vol. 2.400 réis. - Observações sobre a prosperidade do Brasil, 1 vol. 1280 réis. - Refutação das declamações contra o comércio inglês, 2 vol. 2.400 réis. - Reflexão sobre o comércio dos seguros, 480 . Princípios de Economia Política, 3.200. ${ }^{47}$
\end{abstract}

Nas Observações sobre o comércio franco no Brasil, Silva Lisboa procura defender e legitimar, em particular, a instituição da liberdade de comércio pela Carta Régia de abertura dos portos, da qual ele se considerava um dos mentores e na qual ele enxergava a aplicação prática das idéias de Adam Smith. ${ }^{48}$ Logo na Justificativa com que abre a sua obra, Silva Lisboa deixa explícita a sua intenção de fazer um elogio à nova política do Príncipe Regente:

Senhor, devendo ser o voto de quaisquer fiéis vassalos que o nome de V.A.R. seja celebrado em todas as nações; e sendo o meu principal empenho que a humanidade consagre a V.A.R. o título de Libertador do Comércio; (...) considerei que seria de algum serviço ao Estado o fazer apreciar em público a incomparável mercê que V.A.R. se dignou conferir a estes seus domínios ultramarinos, permitindo a franqueza do comércio; sendo este imenso benefício o precursor de muitos outros, com que se liberaliza continuamente o bem geral. (...) pois estou convencido que a franqueza do comércio, regulada pela moral retidão, e bem comum, é o princípio

\footnotetext{
${ }^{47}$ Gazeta do Rio de Janeiro, no 61, 29 de julho de 1812.

48 "Acresce que tendo participado da honra de concorrer para a dita resolução soberana, sendo ouvido em qualidade especial do meu emprego, a equidade exige indulgência à sustentação de princípios”. LISBOA, J. da S. Observações sobre o comércio franco no Brasil, p. 66.
} 
vivificante da ordem social, e o mais natural, e seguro meio da prosperidade das nações. $^{49}$

Segundo Penalves Rocha, a importância da obra econômica de Silva Lisboa residiria justamente na destinação que ele deu à Economia Política, utilizando seu vocabulário e seu aparato conceitual para defender e legitimar as mudanças em curso no Império Português depois da transferência da Corte para a América. ${ }^{50}$ Ressalta esse autor que o nexo entre Economia Política e poder do Estado no Império Português do início do século XIX somente se torna inteligível se levarmos em consideração o quadro de desestabilização provocado pelo estabelecimento da sede da monarquia no Rio de Janeiro. A necessidade de estabelecer as bases políticas do novo Estado levou a monarquia a privilegiar os interesses dos grupos influentes da sociedade colonial (grandes proprietários e comerciantes abastados, principalmente do Centro-Sul), pelo atendimento de suas demandas. A política econômica levada a cabo a partir de então, desagradou outros grupos, principalmente a burguesia mercantil e manufatureira do Reino, paulatinamente preterida em seus direitos e reivindicações. Esses setores sociais sentiam-se lesados e se opunham à nova política econômica do Príncipe Regente, contestando a legitimidade do seu governo do Império. ${ }^{51}$ A tarefa a que se dedicou Silva Lisboa, como autor de obras de Economia Política e, principalmente, como Diretor da Impressão Régia do Rio de Janeiro e censor régio, foi a de rebater tais críticas:

\begin{abstract}
Não dissimulo que as vantagens do comércio franco têm sido controvertidas por escritores de nota; e que as circunstâncias de cada país podem justificar algumas restrições, temporárias, ou permanentes, do tráfico estrangeiro, compensando-se, por cálculo prudente, com o bem geral. Assim protesto, que em nada intento deprimir o patriotismo, e mérito dos que discordam de mim em tal assunto. Respeito o juízo de todos; não presumo que o meu seja a medida da verdade, só desejo que prevaleça o que for realmente o mais útil ao Estado. ${ }^{52}$
\end{abstract}

Rubens Borba de Moraes chama a atenção para o oportunismo da publicação de obras que propagandeassem e elogiassem a franqueza do comércio e, consequentemente, a nova política econômica da monarquia portuguesa naquele momento: "Um livro como o de Silva Lisboa, defendendo o comércio livre e

\footnotetext{
${ }^{49}$ Ibid., p. 63/64.

${ }^{50}$ ROCHA, A. P. José da Silva Lisboa: Visconde de Cairú, p. 36.

${ }^{51}$ ROCHA, A. P. A Economia Política na Sociedade Escravista, p. 115.

${ }^{52}$ LISBOA, J. da S. Observações sobre o comércio franco no Brasil, p. 65/66.
} 
provando baseado nas teorias de Adam Smith, que o 'commercio franco' traria prosperidade para todos não podia deixar de merecer impressão rápida e prioritária." ${ }^{, 53} \mathrm{Na}$ primeira parte das Observações sobre o comércio franco no Brasil, Lisboa se dedica a explicar a inevitabilidade mesma daquela medida, diante das circunstâncias políticas pelas quais passava o Império. Segundo a argumentação do autor, depois da fatal desgraça da invasão de Portugal pelos franceses e da transferência da Corte para o Rio de Janeiro, "era de evidente, absoluta, e inevitável necessidade política, abrirem-se os portos destes domínios ultramarinos ao comércio estrangeiro". ${ }^{54}$ Mas tal medida, apesar de obrigada pelas circunstâncias, seria de efeito benéfico para o Império:

A franqueza do comércio no Brasil será de progressivo interesse à Coroa e nação. Aquela terá mais rendas, em proporção à maior quantidade dos valores importados e exportados, que pagarem os direitos estabelecidos; e esta aumentará continuamente os seus recursos, despertando a letargia em que jazem as indústrias do país, e introduzindo-se outras por novas direções, que a energia do interesse particular, deixada à sua natural elasticidade, removidos todos os obstáculos, deve achar até pela constante emulação e conflito dos competidores nacionais e estrangeiros. ${ }^{55}$

Segundo a argumentação de Silva Lisboa, o comércio franco era uma condição necessária para a instauração no Império Português da Ordem Natural. Apesar de compreender que a Ordem Natural teria sido desvirtuada por uma intromissão indevida do Estado na ordem social, a exemplo de outros reformistas portugueses Silva Lisboa atribuía ao Estado a tarefa de restabelecer aquela mesma ordem. Ideia que aparentemente incluía um paradoxo, como ressalta Antonio Penalves Rocha: o Estado, criador da desordem social, que se manifestava num sem número de conflitos, deveria novamente intervir para restabelecer a ordem. ${ }^{56}$ Silva Lisboa, porém, explica que até então o Estado havia se arrogado o direito de agir em nome do interesse dos indivíduos, colocando-se, por conseguinte, numa posição superior à de qualquer indivíduo. A partir de então, o soberano deveria fazer coincidir os seus interesses com os dos indivíduos, garantindo a realização do bem comum. E era isso que D. João estaria fazendo pelo decreto de liberdade do comércio:

\footnotetext{
${ }^{53}$ MORAES, op. cit., p. 103.

${ }^{54}$ Ibid., p. 67.

${ }^{55}$ Ibid., p. 70/71

${ }^{56}$ ROCHA A. P. José da Silva Lisboa: Visconde de Cairú, p. 85.
} 
Gozando o comércio de inteira liberdade, cada indivíduo aplica os seus fundos e a sua indústria nos ramos que se lhe oferecem com mais vantagens, e que em geral lhes apresentam mais facilidade de adquirir riquezas; e, portanto, todos os indivíduos então trabalham de maneira que possam dar à riqueza nacional o maior crescimento possível; pois que a riqueza nacional é o resultado de todas as riquezas particulares. ${ }^{57}$

Dessa forma, para Silva Lisboa o alvará de Abertura dos Portos, enquanto primeiro passo para advento da Ordem Natural, indicava o início de uma era promissora para o Império Português de uma forma geral, e para a América Portuguesa em particular, sob os efeitos benéficos da livre concorrência regulada pela mão invisível de Deus, ou do mercado. Conseqüência natural desse raciocínio é a condenação categórica dos monopólios particulares. Ainda mais quando criados por determinação de alguma lei ou benefício concedido pelo Estado. Ao mesmo tempo, porém, em que atacava os monopólios que caracterizaram o antigo sistema colonial, Silva Lisboa defendia a manutenção dos monopólios estatais. Uma vez que, no Estado ajustado ao sistema de liberdades naturais o soberano devia fundir o interesse próprio ao interesse dos seus súditos, o autor não coloca sob julgamento o interesse e, consequentemente, a propriedade do soberano. Segundo sua argumentação, os estancos não só não ameaçavam o livre comércio como também constituíam uma medida que beneficiava o bem comum, pois se tratava de uma medida do Estado para aumentar a arrecadação e eximir a sociedade de impostos. Segundo Penalves Rocha, não havia, portanto, nenhuma contradição entre liberdade de comércio e monopólios estatais. A propriedade do Estado seria tão sagrada como as propriedades individuais. ${ }^{58}$

Da livre competição entre os homens empenhados em realizar seus interesses próprios, resultaria o proveito do bem comum, pois a mão invisível de Deus, ou do mercado, acomodaria os conflitos que porventura viessem a ocorrer. Em várias passagens das obras de Silva Lisboa é fácil encontrar referência a esse princípio básico da Economia Política liberal, como nas suas Observações sobre o comércio franco do Brasil:

As circunstâncias do mercado, pela demanda, mais ou menos alta e urgente de certos gêneros, e em certos tempos, podem ocasionar oscilações irregulares nos preços, mais ou menos favoráveis, ora aos vendedores, e ora aos compradores. Porém, onde a franqueza do comércio é estabelecida, todos os gêneros continuamente tendem ao mais aproximado, senão exato, nível e equilíbrio de

\footnotetext{
${ }^{57}$ LISBOA, J. da S. Observações sobre o comércio franco do Brasil, p. 165.

${ }^{58}$ ROCHA, A. P. A Economia Política na Sociedade Escravista, p. 96/97.
} 
valores, isto é, ao seu preço central e natural, que é de bem comum a todos que trazem ao mercado a sua propriedade para a disporem em modos convenientes. ${ }^{59}$

Nas suas Observações sobre a prosperidade do Estado pelos liberais princípios da nova legislação do Brasil, publicadas em 1810, Silva Lisboa responde à objeção de que o livre comércio, em vez de impedir a formação de monopólios particulares como ele afirmava, daria aos estrangeiros o monopólio do comércio com a América portuguesa ou os atrairia a fazer uma nociva concorrência aos comerciantes portugueses. Contra essa objeção, argumentava Silva Lisboa que a plena liberdade para comprar e vender garantiria, em qualquer circunstância, que ambas as partes envolvidas na relação de troca seriam beneficiadas. Segundo sua argumentação, o "verdadeiro e pernicioso monopólio" era o privilégio de comprar e vender sem concorrentes:

Só monopolistas e aspirantes de exclusivos sem título e à custa do bem comum se podem mortificar com tão benigno e paternal sistema de governo, que ampara e contenta a todos, e não mostra as odiosas predileções introduzidas pela terrível polícia do velho sistema mercantil, que tinha odiado com perpétuo conflito e irreconciliável inimizio, corporações e indivíduos, resultando daí o triste contraste entre a desmerecida e desmarcada opulência de poucos e a sistemática organização da miséria de inumeráveis que, ainda com os maiores esforços de indústria e probidade, eram impossibilitados de melhorar de condição. ${ }^{60}$

Respondia também, à objeção de que a liberdade de comércio sacrificaria a metrópole às colônias, destruindo o comércio e as fábricas do Reino. Contra essa ideia, Silva Lisboa argumentava que o livre comércio além de beneficiar a classe mercantil sediada na colônia e, consequentemente, a Coroa (pelo aumento de arrecadação), promoveria também a conciliação dos interesses dos diferentes setores sociais do Império, pois

O verdadeiro interesse do soberano é que as colônias sejam cordialmente unidas a seu governo e pátria comum, e que prosperem o mais possível; pois, de sua íntima união e constante prosperidade depende a maior possível renda e força do Estado. A franqueza do comércio não tende a sacrificar a metrópole aos domínios ultramarinos; mas fazer crescer todas as partes integrantes da monarquia pelos seus

\footnotetext{
${ }^{59}$ LISBOA, J. da S. Observações sobre o comércio franco no Brasil, p. 71/72. Como explica Penalves Rocha, a conciliação dos interesses seria o desdobramento natural do livre comércio, que deveria ser aceito pelas diferentes classes que participavam dos negócios no império por uma simples razão: era uma atividade beneficente para todos, além de ser natural, pois, no final das contas, nenhuma nação podia produzir tudo o que necessitava. ROCHA, A. P. A Economia Política na Sociedade Escravista, 107.

${ }^{60}$ LISBOA, J. da S. Observações sobre a prosperidade do Estado pelos liberais princípios da nova legislação do Brasil. Rio de Janeiro: Na Impressão Régia, 1810. p. 22/23.
} 
naturais meios de crescimento, e não à custa das outras. ${ }^{61}$

Ao mesmo tempo, o pensamento de Silva Lisboa prometia também à classe dirigente do Império que a liberdade de comércio, pela sua capacidade de promover o desenvolvimento econômico, atenuaria as tensões sociais. Uma vez que, pelo pensamento econômico do final do século XVIII e início do XIX, a propriedade privada e as desigualdades sociais também eram compreendidas como inerentes à Ordem Natural, havia a necessidade de atenuar a desigualdade para resolver o problema dos conflitos sociais:

\begin{abstract}
Ainda que seja inexterminável a pobreza da sociedade civil, isto é, o estado das classes inferiores que não têm terras e capitais para se manterem dos seus reditos e que, portanto, são obrigados a submeter-se à Lei do trabalho; contudo, é possível que não exista a indigência e mendicidade havendo leis favoráveis à indústria e exterminadoras de monopólios odiosos. Porque então haverá o natural e indefinido progresso da opulência que, sob o influxo e diretório da religião, dará espontaneamente, com o supérfluo dos ricos o justo suprimento aos que não podem trabalhar ou não acham emprego. ${ }^{62}$
\end{abstract}

A sociedade colonial era marcada por uma acentuada desigualdade, sobre a qual pesava a ameaça de uma revolução feita pelos destituídos da propriedade, reforçada pelos acontecimentos do Haiti. Segundo o raciocínio de Silva Lisboa, a incapacidade para favorecer o bem comum, demonstrava a artificialidade do sistema colonial e a sua ingovernabilidade. O livre comércio afastaria a hipótese de tal revolução porque superaria a ordem colonial e a ultrapassaria em favor de uma ordem civil melhorada, refinada, plena de civilidade. Dessa forma, através da prática do livre comércio estaria assegurada a riqueza nacional e, consequentemente, a ordem social:

A Economia Política, inquirindo os regulares meios do inocente e natural progresso da opulência, demonstrando as péssimas consequiências dos odiosos monopólios, convencendo o fatal erro de se ter o ouro e a prata como a riqueza essencial das nações, expondo os meios de todos os povos se enriquecerem e prosperarem pelo comércio legítimo, sem que o benefício de uns se converta em malefício dos outros, contribui a exterminar a excessiva desigualdade dos indivíduos e as causas das guerras, e a dar à todas as classes e nações harmonia e prosperidade. ${ }^{63}$

Como chama a atenção Penalves Rocha, tendo em conta o conjunto de benefícios trazidos pelo livre comércio, nota-se que ele assumia no pensamento de

\footnotetext{
${ }^{61}$ LISBOA, J. da S. Observações sobre o comércio franco do Brasil, p. 155.

${ }^{62}$ LISBOA, J. da S. Estudos do Bem Comum e Economia Política, p. 150/151.

${ }^{63}$ Ibid., p. 156.
} 
José da Silva Lisboa um caráter quase demiúrgico ao proporcionar desenvolvimento econômico, atenuação das diferenças sociais e paz entre as nações. Dessa forma, o discurso econômico colaborava para a acomodação do Estado português às novas circunstâncias "fornecendo às partes que o compunham a perspectiva de alcançarem uma ordem natural, que teria como signos a abundância e a felicidade". ${ }^{64}$ Sem perder de vista o nosso objetivo, que é analisar as idéias econômicas de Silva Lisboa em relação com os contextos históricos nos quais elas foram formuladas, ressaltando a relação entre a sua produção bibliográfica (principalmente a produção pós-1808, publicada pela Impressão Régia do Rio de Janeiro) e os imperativos da administração do Estado português e caracterizando-o como um estadista que intervinha na política econômica; é importante atentar para o fato de que a defesa da liberdade comercial sempre foi pensada pelo letrado bahiense em relação ao monopólio restritivo dominante no antigo sistema colonial. Como chamam a atenção Fernando Novais e José Jobson Arruda, as suas formulações não podem ser pensadas sem este referencial: "Menos do que a defesa intransigente dos princípios do liberalismo, foi o horror ao colonialismo, o combate aos monopólios, aos privilégios, enfim, ao sistema colonial que mobilizaram grande parte de suas energias. $" 65$

O raciocínio que associava Comércio e Civilização tinha como consequiência lógica a condenação das guerras e revoluções, que se oporiam à Civilização na medida mesma em que as convulsões políticas destroem a comunicação e, consequentemente, o comércio entre as nações: “Quem vive em abundância pela fertilidade do país, e tem facilmente supridas as suas gerais precisões, quer gozar dos cômodos da vida e prazeres da civilização; e, em conseqüência, é averso à insubordinação e extravagância e amigo da ordem e da honra". 66 A oposição entre as ideias de revolução e Civilização, por sua vez, levavam à condenação da Revolução Francesa e de Napoleão Bonaparte, seu continuador, encontrada em todos os livros de Silva Lisboa. Bonaparte recebe de Silva Lisboa, entre outras, a alcunha de "exterminador do marítimo comércio europeu", ${ }^{67}$ por ter decretado em novembro de 1806 o Bloqueio Continental, principal causa da transferência da família real portuguesa para o Brasil. Na

\footnotetext{
${ }^{64}$ ROCHA, A. P. A Economia Política na Sociedade Escravista, p. 117.

${ }^{65}$ NOVAIS e ARRUDA, op. cit., p. 237/238.

${ }^{66}$ LISBOA, J. da S. Estudos do Bem Comum e Economia Política, p. 434.

${ }^{67}$ LISBOA, J. da S. Observações sobre o comércio franco do Brasil, p. 69.
} 
narrativa de Lisboa, os planos de Napoleão seriam "um sistema monstruoso, que tende a excluir o continente europeu do mapa do mundo civilizado". ${ }^{6}$ Porém, unindo-se à Inglaterra e decretando a abertura dos portos da América portuguesa, o monarca português teria desafiado aquele sistema:

E, enquanto a atroz galomania continua em suas devastações sem limites, ameaçando a geral pobreza e privação das doçuras da vida, no corte do comércio marítimo entronizando o alcorão proibitivo, inutilizando as descobertas das três partes do mundo e vedando os portos da Europa à Nação mais rica e industriosa do Norte; o amável príncipe lusitano franqueia as suas baías, enseadas, portos e terras a todos os amigos a mútua comunicação dos dons da Natureza e Arte de todos os países. ${ }^{69}$

Dessa forma, segundo a argumentação de Silva Lisboa, a defesa da política de livre comércio da Coroa portuguesa passava pela defesa da manutenção do livre comércio com a Inglaterra, um dos poucos, senão o único, "amigo" que a monarquia portuguesa podia encontrar naquele momento. Silva Lisboa elenca uma série de benefícios advindos da manutenção desse comércio mas, acima de tudo, a defesa desse comércio equivaleria à defesa da Civilização:

Como a nação inglesa tem, por assim dizer, com vigor atlântico metido ombros ao mundo, e sustenta impávida o edifício da civilização para salvar a Europa do barbarismo eminente; é necessário que, participando das vantagens do seu comércio, entremos em competente partilha, não só de proporcional segurança, independência e força, mas também da honra de não dobrar o joelho ao ídolo do século, ante quem se prostraram tantas ilustres monarquias, e de ganhar a glória que parece estar reservada às nações que abrirão e alargarão a comunicação dos homens, estendendo a esfera dos seus bens e conhecimentos. ${ }^{70}$

Toda a segunda parte das Observações sobre o comércio franco do Brasil é dedicada a ressaltar os benefícios e a necessidade da manutenção desse comércio, pois "se a franqueza do comércio com todas as nações é útil ao Brasil, ela é imprescindível com os ingleses, por necessidade, interesse, política e gratidão nacional". ${ }^{71}$ Necessidade, antes de qualquer coisa, de seguir os exemplos dados

\footnotetext{
${ }^{68}$ LISBOA, J. da S. Observações sobre a prosperidade do Estado pelos liberais princípios da nova legislação do Brasil, p. 9/10.

${ }^{69}$ Ibid., p. 8/9. Interessante notar como Silva Lisboa se refere ao alcorão proibitivo, utilizando o livro sagrado dos muçulmanos como sinônimo de barbárie, de falta de comunicação e comércio entre os povos.

${ }^{70}$ LISBOA, J. da S. Observações sobre o comércio franco do Brasil, p. 96.

${ }^{71}$ Ibid., p. 75. O dever de gratidão de Portugal para com a Inglaterra estaria relacionado ao auxílio britânico prestado nos momentos de urgência da monarquia portuguesa: "O governo inglês já nos socorreu na grande catástrofe do terremoto de Lisboa, suprindo-nos do necessário. Agora nos
} 
pela Inglaterra em termos de política econômica para, aproveitando-se desse contato, alcançar o mesmo nível de desenvolvimento econômico e de Civilização:

A nossa nação sempre deu provas de especial gênio para o comércio e navegação. É de esperar que tratando mais familiarmente com a nação que excede em todas em agência mercantil e náutica, entre no espírito das suas combinações, se molde à sua atividade, e obtenha vantagens incalculáveis. A semelhança e o exemplo são os maiores estímulos das ações humanas. Estando em maior contato com os povos mais civilizados, é impossível que não nos emparelhemos à sua indústria. ${ }^{72}$

Mas necessidade política também, ditada pela conjuntura do comércio internacional. Estando o comércio marítimo interditado a todas as nações européias pelo decreto napoleônico, o comércio franco com os ingleses se apresentava como "a única sagrada âncora que nos resta para a nossa salvação e esperanças": $:^{73}$

A amizade e aliança do governo britânico constitui-se de um imenso valor político na atual conjuntura, em que não só era forçoso escolher entre as duas preponderantes nações da Europa, mas também porque estávamos na mais urgente precisão de desobstruir o nosso comércio, e estender o mercado das possessões da Coroa, para adquirirmos os meios proporcionados a sustentar com honra a causa do soberano e da nação, repelindo as tentativas do inimigo e forçando-o à reintegração da monarquia; o que seria impossível sem a mais íntima união com o dito governo, e abertura dos portos do Brasil. ${ }^{74}$

Diante de tais circunstâncias, a manutenção do comércio franco com a Inglaterra se apresentava mesmo como defesa contra o comércio de contrabando que, segundo a argumentação de Silva Lisboa, seria a inevitável conseqüência da falta do comércio franco e da política de sobrecarregar as mercadorias com "mui gravosos direitos e outros sabidos vexames fiscais": ${ }^{75}$

Depois é claro que, a não se admitir o comércio franco e legal, não se poderia impedir o clandestino e ilegítimo numa costa imensa, cheia de portos, baías e surgidouros, tendo o país carências de tantos suprimentos, e vendo-se os ingleses na urgência de procurar extração aos produtos da sua indústria, com maior vivacidade que nunca, em todas as partes da terra. ${ }^{76}$

acudiu oportunamente no ainda maior terremoto político, prestando-nos todos os notórios socorros que a humanidade podia exigir". Ibid., p. 117.

${ }^{72}$ Ibid., p. $83 / 84$.

${ }^{73}$ Ibid., p. 94.

${ }^{74}$ Ibid., p. 96.

${ }^{75}$ Ibid., p. 104.

${ }^{76}$ Ibid., p. 76. Diante de legislações restritivas do comércio, Silva Lisboa consegue enxergar até mesmo um papel civilizatório no contrabando: "Os contrabandistas suprem em parte o déficit dos necessários suprimentos dos povos e, assim, têm promovido a geral emulação e o espírito da sociedade, ainda que às vezes tenham sido vítimas mal fadadas de errôneas legislações”. Ibid., p. 193. 
O interesse da Coroa portuguesa na manutenção do comércio franco com a Inglaterra é sintetizado por Silva Lisboa em três efeitos positivos desse comércio: $1^{\circ}$ ) dar saída aos gêneros produzidos no Brasil; $2^{\circ}$ ) estender a sua indústria e; $3^{\circ}$ ) inspirar-nos o estudo da língua e imitação do seu espírito público. Para justificar essa asserção, Silva Lisboa lança mão do exemplo dos recém-independentes Estados Unidos da América que, após separarem-se da Inglaterra, preferiram privilegiar o comércio com os ingleses, não obstante todas as razões de queixa que teriam contra a sua antiga metrópole, do que com os franceses, apesar de todo o auxílio que receberam destes últimos durante a sua guerra de independência. Segundo Lisboa, nenhuma nação da Europa atingiu em tão pouco tempo "um quadro tão brilhante de prosperidade progressiva" quanto os Estados Unidos. ${ }^{77} \mathrm{E}$ a razão do seu rápido desenvolvimento econômico não teria sido a extensão e fertilidade da América do Norte, que de resto não era maior do que a da América do Sul, "mas a franqueza em admitir não só a importação de bens e mercadorias dos estrangeiros, e também a de suas pessoas e indústrias úteis". ${ }^{78}$ Segundo a argumentação de Silva Lisboa, a América Portuguesa haveria de se beneficiar de forma ainda mais significativa do comércio franco com a Inglaterra:

Se, pois, os Estados Unidos, depois de arruinados por uma cruel guerra, usando aquele expediente, já tanto avultam no teatro político, a que altura se deve esperar que o Brasil se eleve em riqueza, população, indústria e potência, adotando-se com firmeza igual política, estando na situação a mais favorável para a correspondência mercantil em todas as partes do globo; tendo tantas e tão boas terras e excelentes portos, compreendendo variedades de climas os mais próprios à existência humana; cheio de produções geniais e prolíficas, e capaz de fazer naturalizar muitas outras, como já se tem experimentado. ${ }^{79}$

Para convencer seus interlocutores da necessidade de manutenção do comércio com a Inglaterra, Silva Lisboa lança mão de exemplos de prosperidade proporcionados por esse comércio no Reino, referindo-se à riqueza conseguida com a venda do vinho do Porto:

\footnotetext{
${ }^{77}$ Ibid., p. 92.

${ }^{78}$ Ibid.

79 Ibid. E, finalmente, a necessidade de manutenção do livre comércio com a Inglaterra era justificado pelo o dever de gratidão de Portugal para com aquela nação, relacionado ao auxílio britânico prestado nos momentos de urgência da monarquia portuguesa: "O governo inglês já nos socorreu na grande catástrofe do terremoto de Lisboa, suprindo-nos do necessário. Agora nos acudiu oportunamente no ainda maior terremoto político, prestando-nos todos os notórios socorros que a humanidade podia exigir". Ibid., p. 117.
} 
Todos sabem que a riqueza, e população do Porto, e o crédito de seus vinhos, é obra em grande parte da riqueza e comércio de Inglaterra. A prosperidade da Ilha da Madeira deriva da mesma fonte. A franqueza de comércio inglês ocasionava aqui uma exportação e renda à Coroa a qual nunca deu capitania alguma do Brasil proporcionalmente à extensão do seu território. ${ }^{80}$

Nessa passagem Silva Lisboa provavelmente se refere aos efeitos do Tratado de Methuen, celebrado em 1703, por meio do qual os têxteis ingleses passaram a ser admitidos em Portugal; em troca, os vinhos portugueses destinados à Inglaterra foram beneficiados com a redução de um terço dos direitos em relação aos vinhos franceses, seus principais concorrentes no mercado inglês. Tratado esse apontado por letrados e comerciantes reinóis como o responsável por carrear para fora do reino todo o ouro extraído da América portuguesa, por desorganizar a nascente indústria têxtil portuguesa e por colocar a economia portuguesa em uma situação de completa subordinação em relação à Inglaterra. ${ }^{81}$ Partindo da percepção de que as críticas ao Tratado de Methuen eram, ao fim a ao cabo, críticas à falta de reciprocidade no comércio mantido com a Inglaterra, Silva Lisboa se vê compelido a partir em defesa daquele tratado como parte necessária da sua defesa da manutenção do comércio livre com a Inglaterra:

\begin{abstract}
As vantagens que os ingleses tinham em virtude do Tratado de Methuen, e por outras graças do nosso governo, não diminuíam, antes muito promoveram, os interesses da agricultura e comércio do Reino; pois, segundo já acima se observou, os grandes ramos da indústria rural e mercantil, em que o povo tinha mais emprego, e o Estado mais renda, eram as consequiências do vasto e certo mercado dos ingleses. Sendo esses os maiores compradores e os melhores pagadores dos nossos gêneros. ${ }^{82}$
\end{abstract}

Àqueles que não viam com bons olhos a manutenção de relações privilegiadas de comércio com a Inglaterra, das quais o Tratado de Methuen era só um exemplo que logo seria seguido por outros, como os Tratados de 1810, respondia Lisboa que a Grã-Bretanha "já era opulenta e poderosa muito antes que tivesse tratados com Portugal, ainda que sem dúvida também cresceu em opulência e poder com as relações mercantis do nosso Reino". ${ }^{83}$ E que, se a amizade dos ingleses era interesseira, como afirmavam os críticos, sorte a de

\footnotetext{
${ }^{80}$ Ibid., p. 84.

${ }^{81}$ Letrados estrangeirados como D. Luis da Cunha e o próprio Marquês de Pombal escreveram a respeito daquilo que eles consideravam os efeitos negativos do Tratado de Methuen sobre a economia portuguesa. A esse respeito ver FALCON, F. J. C. A Época Pombalina, p. 231 a 316.

${ }^{82}$ LISBOA, J. da S. Observações sobre o comércio franco do Brasil, p. 102.

${ }^{83}$ Ibid., 104.
} 
Portugal que os interesses comerciais e político de Inglaterra coincidissem com os da monarquia lusitana:

Felizmente os interesses políticos e comerciais da Grã-Bretanha nesta época coincidem e ajustam-se com os nossos o mais exatamente que se poderia desejar. Uns e outros estão de tal modo identificados, que há toda a razão para esperar, até à mais remota posteridade, sempre enérgica e fiel cooperação do seu governo, para o esplendor do império lusitano. ${ }^{84}$

Por fim, respondendo às críticas daqueles que, referindo-se velada ou explicitamente ao comércio de Portugal com a Inglaterra, consideravam absurda a permissão de se importarem mercadorias de outros Estados sem que estes praticassem igual reciprocidade, Silva Lisboa afirmava que é a reciprocidade das precisões que liga os homens de diversos países e que decide da quantidade e constância de suas mútuas relações comerciais, e onde não há mútua carência e demanda não pode haver câmbio. Vendendo Portugal aquilo de que a Inglaterra tem necessidade e comprando daquela os gêneros de que necessita estaria estabelecida a reciprocidade, que não deveria ser medida pela exata correspondência do franco troco das mercadorias respectivas, tomadas individualmente, mas sim coletivamente, pela soma do valor total. Dessa forma, mesmo entre nações que não pratiquem a mesma franqueza de comércio, não poderia deixar de haver reciprocidade:

Pois todas fazem os possíveis esforços (como os indivíduos que compram e vendem) de ultimar cada ano o seu troco das respectivas mercadorias, dando valor por valor igual. Ainda que uma compre à outra menor soma de produtos rudes ou manufaturados, e esta seja necessitada de pagar a diferença do preço, isto é, o saldo ou balança em dinheiro ou metais preciosos; todavia sempre se verifica ter-se feito a transação da reciprocidade de precisões em valor por valor igual. ${ }^{85}$

Após a conclusão do Tratado de Comércio e Navegação de 1810, "arrancado à condescendência anglófila de D. Rodrigo de Sousa Coutinho após dois anos de laboriosas conversações", segundo Oliveira Lima, ${ }^{86}$ os críticos da

\footnotetext{
${ }^{84}$ Ibid., p. 107.

${ }^{85}$ Ibid., p. 170. Complementa o autor que a ausência de liberalidade no comércio não deveria ser combatida com iguais medidas restritivas, pois o efeito seria prejudicial para aquele Estado mesmo que adotasse tais medidas, afastando-se da ordem natural: "Ainda que os outros Estados procedam com injustiça ou menor liberalidade, nem por isso a sabedoria política de um governo de princípios sólidos e filantrópicos se manifestaria em retaliações, isto é, em iguais procedimentos vingativos (...): antes ao contrário, ela se fará patente na superioridade das luzes e prudência, seguindo invariavelmente um sistema conforme à ordem da natureza e comuns instintos e interesses do gênero humano". (Ibid., p. 169)

${ }^{86}$ LIMA, O. D. João VI no Brasil, p. 246.
} 
falta de reciprocidade nas relações comerciais entre Portugal e Inglaterra ganharam farta munição. Entre a abertura dos portos, em 1808, e o tratado de 1810 os vinhos, licores espirituosos e azeites pagavam direitos de entrada de 48\%, mas todas as mercadorias transportadas em navios portugueses pagavam um terço desse valor. Após diversas negociações ficaram livres do pagamento de direitos aquelas mercadorias que já o tivessem feito em Portugal, assim como os produtos da maior parte das colônias portuguesas; ficaram sujeitas à taxa de $24 \%$ as mercadorias estrangeiras transportadas em navios estrangeiros; sujeitas à taxa de $16 \%$ as mercadorias portuguesas ou estrangeiras transportadas em navios portugueses; e à taxa de $15 \%$ as mercadorias britânicas transportadas em navios britânicos ou portugueses. Como afirma Oliveira Lima: "Não admira, portanto, que o convênio com a Inglaterra fosse nacionalmente considerado um desastre pelos espíritos imparciais". ${ }^{87}$ Segundo esse autor, a falta de reciprocidade "era absoluta e dava-se em todos os terrenos", sendo difícil de ser estabelecida pela carência de artigos que se equilibrassem na necessidade do consumo, sendo mais precisos no Brasil os artigos manufaturados ingleses do que à Inglaterra as matérias primas brasileiras: "Dava-se ainda a desigualdade na importância que respectivamente representavam suas exportações para os países produtores, constituindo a Inglaterra o mercado quase único do Brasil, ao passo que aquela nação dividia por muitos países os seus interesses mercantis". 88

José Acúrsio das Neves era um dos mais acirrados críticos da falta de reciprocidade praticada no comércio internacional, em geral, e da sua existência nos tratados celebrados com a Inglaterra, em particular. Com muita perspicácia observa ele que: "Os tratados de comércio entre duas nações desiguais em poder ordinariamente redundam em prejuízo da mais fraca, principalmente quando também esta é menos industriosa". ${ }^{89}$ Sendo este o caso em que se encontrava Portugal frente à Grã-Bretanha. Escrevendo sobre o Tratado de 1810, em uma consulta da Real Junta do Comércio de 9 de dezembro de 1816, inserida na sua Memória de 1820, aponta Acúrsio os prejuízos decorrentes da falta de

\footnotetext{
${ }^{87}$ Ibid.

${ }^{88}$ Ibid., p. 251. Diante da crescente maré de críticas ao tratado, Silva Lisboa se viu compelido a sair novamente em defesa da política econômica da monarquia, publicando uma Refutação das declamações contra o commercio inglez, extrahida de escriptores eminentes, em 2 volumes publicados pela Impressão Régia do Rio de Janeiro nos anos de 1810 e 1811.

${ }^{89}$ NEVES, J. A. das. Memória sobre os meios de melhorar a indústria portuguesa, considerada nos seus diferentes ramos, p. 158.
} 
reciprocidade existente tanto nos termos pelos quais ele foi celebrado, fruto das necessidades daquele momento, quanto na forma como ele vinha sendo executado:

O tratado de comércio com a Inglaterra, calculado em circunstâncias muito diferentes das atuais e ditado talvez por motivos que não me é lícito investigar, precisa de corretivos que o façam menos pesado e de muita vigilância para que se não abuse dele. ${ }^{90}$

Para Acúrsio, tal tratado era muito mais prejudicial até do que o Tratado de Methuen, ao qual ele atribuía a destruição da nascente manufatura portuguesa na primeira metade do século XVIII:

Clamamos por mais de cem anos contra o Tratado de Methuen, e toda a Europa nos achou razão, menos os ingleses, porque as nossas fábricas de lanifícios se arruinaram com a admissão dos da Grã-Bretanha, mas o dano agora é maior porque se estende a quase todos os gêneros de manufaturas. ${ }^{91}$

Sua maior crítica, porém, se refere à falta de reciprocidade na execução dos já desiguais termos do tratado:

Estamos admitindo aos ingleses os seus lanifícios e todas as suas mercadorias pagando de direitos somente quinze por cento e eles, não contentes com carregarem tanto os nossos vinhos que os elevam a mais do duplo do valor, estudam o modo de dificultar a sua entrada. ${ }^{92}$

Segundo análise de Acúrsio, após o fim da guerra de canhão na Europa, havia começado a guerra das alfândegas. Apesar de admitir que a liberdade de comércio e indústria deveria ser um principium vitae da política econômica dos Estados, afirma Acúrsio que diante das políticas restritivas praticadas pelos outros países, essa liberdade não passava de uma ficção. No volume 1 das suas Variedades, publicado em 1814, antes mesmo do final da guerra na Europa, portanto, Acúrsio já havia se referido à política restritiva que vinha sendo praticada pelos Estados:

\footnotetext{
${ }^{90}$ Ibid., p. 136.

${ }^{91}$ Ibid. Um ano depois, no segundo volume das suas Variedades, Acúrsio é categórico a respeito do Tratado de Methuen: "Quanto a mim, o Tratado concorreu muito para a ruína das nossas manufaturas; porque se há casos em que seja necessário recorrer ao sistema proibitivo para que a indústria estrangeira não sufoque na nascença os estabelecimentos fabris nacionais, tal era o de Portugal naquela época". NEVES, J. A. das. Variedades sobre objetos relativos às artes, comércio e manufaturas, consideradas segundo os princípios da economia política, v.2, p. 328.

92 NEVES, J. A. das. Memória sobre os meios de melhorar a indústria portuguesa, considerada nos seus diferentes ramos, p. 137.
} 
A perfeita liberdade de comércio e de indústria, se pudesse estabelecer-se em circunstâncias favoráveis, seria uma fonte inexaurível de abundância e de riqueza; mas é o que jamais se poderá verificar, menos que se realizem os belos sonhos políticos de alguns bons homens, que conceberam a idéia de sujeitar o mundo inteiro às regras que lhe prescreveram nos seus gabinetes. $\mathrm{O}$ que até aqui se tem chamado estabelecer a liberdade do comércio e da indústria, não tem sido mais que alargar algumas linhas às prisões que os encadeiam. Se eu franqueio a minha casa aos meus vizinhos e eles me negam a entrada nas suas, o meu partido fica desigual; $\mathrm{e}$, neste caso se acharia uma nação que franqueasse inteiramente às outras o seu comércio sem que elas adotassem igual sistema. ${ }^{93}$

Discordando de Silva Lisboa, pregava Acúrsio que também Portugal deveria adotar medidas que protegessem o seu comércio e indústria da concorrência estrangeira:

Não há um Estado, por mais pequeno que seja, onde não respire o ciúme contra as manufaturas estrangeiras, e se não procurem os meios de vedar a sua entrada; nós estamos em uma direção contrária e a nossa indústria é esmagada com o peso da estrangeira. $^{94}$

De Londres, outro letrado da Geração de 1790 esteve sempre atento às novidades que aconteciam na nova sede do Império. Hipólito José da Costa, comentando no seu Correio Braziliense a publicação das Observações sobre o comércio franco no Brasil, louvava a inauguração da tipografia no Brasil, ao mesmo tempo em que exprimia a sua opinião sobre o autor e a obra:

É com prazer além de ordinário que tenho de anunciar ao Mundo a primeira obra impressa no Brasil (já no Brasil se imprime!). O autor é bem conhecido na literatura portuguesa; e tanto por ter ele a reputação já estabelecida, como pelo respeito que a sua primeira obra me inspirou pelos seus conhecimentos jurídicos, me permitirá que, expondo ao público os seus sempre úteis raciocínios, me arrisque eu a dar a minha opinião ainda quando oposta à sua. ${ }^{95}$

Hipólito criticava, porém, a postura subserviente do letrado bahiense, refutando a idéia expressa no Prólogo do livro de Silva Lisboa de que os atos do governo de D. João, "procedendo da mais circunspecta deliberação" não deveriam encontrar oposição, “ainda só de pareceres". ${ }^{96}$ Rebate Hipólito:

O estar eu habituado a ver em Inglaterra discutir publicamente as medidas do Governo; e conhecer os bens que daí resultam à nação, me faz receber de muito mau grado este princípio que aqui se insinua, de extrema submissão às opiniões do

\footnotetext{
93 NEVES, J. A. das. Variedades sobre objetos relativos às artes, comércio e manufaturas, consideradas segundo os princípios da economia política, v.1, p. 149.

${ }^{94}$ NEVES, J. A. das. Memória sobre os meios de melhorar a indústria portuguesa, considerada nos seus diferentes ramos, p. 136.

${ }^{95}$ COSTA, H. J. da. Correio Braziliense ou Armazém Literário. Maio 1809. p. 474.

${ }^{96}$ LISBOA, J. da S. Observações sobre o comércio franco no Brasil, p. 66.
} 
governo. (...) Se se admite o princípio de que é contra o decoro civil haver oposição ainda de pareceres às medidas do governo, qual virá a ser o estado da nação onde o conselheiro for ignorante ou malicioso? ${ }^{97}$

A maior parte da resenha que Hipólito faz da obra de Silva Lisboa diz respeito à sua argumentação a favor do livre comércio com a Inglaterra. Escrevendo de Londres, esse assunto devia ser do particular interesse dos leitores do Correio Braziliense que, como ressalta Tereza Cristina Kirschner, contava entre outros auxílios, com o de negociantes portugueses estabelecidos naquela cidade. $^{98}$ Antes de qualquer coisa, Hipólito não deixa de notar a característica de resposta às críticas feitas a esse comércio que assume a argumentação de Lisboa:

O autor, depois de haver mostrado, em geral, que se devia permitir a todas as nações estrangeiras o comerciar com o Brasil, se ocupa agora, tão de propósito, a demonstrar uma proposição incluída naquela; que se deve permitir aos ingleses o negociar com o Brasil; e para salvar o autor de uma escusada redundância é necessário supor a existência de um partido no Brasil que seja contrário ao franqueamento do comércio daquele país com a Inglaterra. ${ }^{99}$

Conclui Hipólito que se realmente existia tal partido, deveria ele ser composto de pessoas ou mui ignorantes ou mal intencionadas, pois não havia dúvida de que se deveria patentear o comércio do Brasil aos ingleses e às outras nações. ${ }^{100}$ Nesse ponto parece patente o comprometimento de Hipólito com seu público leitor: os negociantes portugueses estabelecidos em Londres, muitos dos quais deveriam ser comissários de casas comerciais inglesas. No entanto, como vimos, aquele partido de fato existia, ainda que se encontrasse antes em Portugal do que no Brasil, e não era composto, ao contrário do que afirma Hipólito, por pessoas ignorantes ou mal intencionadas, mas sim por letrados e funcionários do aparelho administrativo do Império de reconhecida competência e conhecimento econômico, tais como Acúrsio das Neves.

Apoiado no que teve a oportunidade de observar na sua viagem a Filadélfia em 1798, Hipólito invalida a utilização do exemplo do comércio franco dos Estados Unidos com a Inglaterra e a conclusão de Silva Lisboa de que igual comércio prometeria semelhantes resultados com a América Portuguesa. Segundo Hipólito, a prosperidade dos Estados Unidos não era devida ao comércio com a

\footnotetext{
${ }^{97}$ COSTA, H. J. da. Correio Braziliense ou Armazém Literário. Maio de 1809, p. 475.

${ }^{98}$ KIRSCHNNER, T. C. José da Silva Lisboa, Visconde de Cairú, p. 171/172.

${ }^{99}$ COSTA, H. J. da. Correio Braziliense ou Armazém Literário. Julho 1809. p. 49/50.

${ }^{100}$ Ibid., p. 50
} 
Inglaterra, mas à existência de boa legislação e de um governo livre, o que não havia no Império português. E era devido à liberdade ilimitadíssima que o comércio norte-americano gozava, que os ingleses não podiam tirar ali vantagens demasiadas:

Nos Estados Unidos não há monopólio algum de diamantes, de pau-brasil, de cartas de jogar, de urzela, etc; não há privilégios de qualidade alguma para ninguém; não há direitos alguns de exportação; mas, pelo contrário, há tal diferença de direitos de tonelada entre os navios nacionais e estrangeiros, que dão uma decidida vantagem aos seus. Donde se segue que o grande comércio que fazem com a Inglaterra, e que é muito útil aos ingleses, é consequiência e não causa primária da prosperidade dos Estados Unidos. ${ }^{101}$

Fazendo uma leitura a contrapelo dos argumentos de Silva Lisboa, Hipólito ressalta que o comércio com a Inglaterra poderia vir a gerar efeitos contrários aos esperados pelo letrado bahiense, na medida mesma em que "o interesse do comprador está na razão inversa do vendedor". ${ }^{102}$ Batendo na mesma tecla que Acúrsio, reconhecia a ausência de reciprocidade, ou mesmo daquela coincidência de interesses a que se refere Silva Lisboa, no comércio entre Portugal e Inglaterra. Para o editor do Correio Braziliense, Lisboa admitia como fato uma hipótese que estava bem longe de verificar-se, porque certamente não havia reciprocidade alguma de vantagens entre o comércio dos negociantes brasilienses em Inglaterra e o comércio dos ingleses no Brasil:

A Carta Régia de que aqui se fala, se é a datada da Bahia, de 28 de janeiro de 1808 admite ao comércio do Brasil os vasos ingleses sem fazer distinção dos nacionais quanto aos direitos que têm de pagar, quando, pelo contrário, em Inglaterra os direitos sobre os vasos do Brasil são, como devem ser, muito maiores que os nacionais; depois, todas as mercadorias inglesas, sem exceção, são admitidas no Brasil, quando em Inglaterra se não admitem alguns dos produtos do Brasil que formam o principal ramo de suas exportações, tal como o açúcar e o café, por exemplo; ou as madeiras finas que, suposto sejam admitidas em Inglaterra é com direitos tão pesados que montam a uma proibição. ${ }^{103}$

Preocupava-se Hipólito que tal engano a respeito da existência de reciprocidade viesse da pena de um Deputado da Junta do Comércio do Rio de Janeiro, pois podia a sua opinião ser de grande consequiência no tratado de comércio que estava por se assinar entre Portugal e Inglaterra. Hipólito se refere ao Tratado de 1810, praticamente prevendo o que estava por vir. Concluindo a sua

\footnotetext{
${ }^{101}$ Ibid., p. 52.

102 Ibid., p. 50.

${ }^{103}$ Ibid., p.53.
} 
resenha, Hipólito comenta a argumentação de Silva Lisboa em defesa do Tratado de Methuen. A esse respeito, o editor do Correio critica a utilização que Lisboa faz de um autor inglês, no caso Adam Smith, para confirmar a sua argumentação. ${ }^{104}$ Segundo Hipólito: "Smith é um excelente economista, mas a sua autoridade neste caso apresenta ao nosso autor um mau apoio, debilitado pela conhecida parcialidade de um inglês que se propunha justificar este tratado, tão favorável à sua nação". 105

Hipólito da Costa volta a comentar as proposições de Silva Lisboa a respeito da liberdade de comércio ao fazer a resenha das Observações sobre a prosperidade do Estado pelos liberais princípios da nova legislação do Brasil. Como escreve o próprio Silva Lisboa, esse livro, mais ainda do que as suas duas outras Observações, foi escrito atendendo ao Decreto de 23 de fevereiro de 1808 que o incumbia de expor para o público os princípios da ciência econômica, "declarando serem absolutamente necessários os respectivos estudos para os seus fiéis vassalos o poderem melhor servir, e achar-se o Brasil em circunstâncias de se adotarem muitos daqueles princípios". ${ }^{106}$ Ressalta Hipólito que, mais do que isso, o livro serve à necessidade de justificar para o público a necessidade das novas medidas tomadas pelo governo de D. João, frente a oposição dos seus críticos. ${ }^{107}$ Ao referir-se ao Comércio, Silva Lisboa destaca como principal realização do governo de D. João, como não podia deixar de ser, a Carta Régia de liberdade do comércio:

\begin{abstract}
"Tenho dito (e nunca assaz repetirei) que, pelo benefício da franqueza do comércio, que S.A.R. concedeu na imortal Carta Régia de 28 de janeiro de 1808, os habitantes deste Estado devem levantar um monumento de eterna gratidão ao mesmo Augusto Senhor, consagrando-lhe os justos títulos de Salvador do Brasil e Libertador dos Povos". ${ }^{108}$
\end{abstract}

\footnotetext{
104 “E é por esta razão que Smith no livro 4, cap. 6 mostra que o sobredito Tratado de Methuen, e subseqüentes favores do nosso governo a bem do comércio dos ingleses não eram tão úteis à GrãBretanha, como vulgarmente se crê”. LISBOA, J. da S. Observações sobre o comércio franco do Brasil, p. 103.

${ }^{105}$ COSTA, op. cit., p. 54.

${ }^{106}$ LISBOA, J. da S. Observações sobre a prosperidade do Estado pelos liberais princípios da nova legislação do Brasil, p. II/III.

${ }^{107}$ COSTA, H. J. da. Correio Braziliense ou Armazém Literário. Dezembro de 1810. p. 604. O livro faz o elogio daquelas medidas, divididas por área de atuação do governo (que correspondem aos seus capítulos): Organização Civil, Polícia, Agricultura, Comércio, Navegação, Indústria, Defesa, Instrução, Finanças, Justiça e Religião. Como ressalta Tereza Cristina Kirschner, esse livro limita-se a sistematizar as idéias já apresentadas nas duas Observações publicadas anteriormente (KIRSCHNER, op. cit., p. 174).

${ }_{108}$ LISBOA, J. da S. Observações sobre a prosperidade do Estado pelos liberais princípios da nova legislação do Brasil, p. 20.
} 
Afirma Hipólito, porém, que a liberdade de comércio não deveria ser considerada um benefício porque os habitantes do Brasil tinham o direito de aplicarem-se a quaisquer ramos de indústria e comércio que desejassem, e se o governo assim o permitia não fazia nenhum bem, apenas se abstinha de cometer um crime que até então praticava. ${ }^{109}$ Além disso, se a medida da abertura dos portos atendia, ao fim e ao cabo, às circunstâncias políticas internacionais ou, como escreve Lisboa, a fatal desgraça da invasão de Portugal pelos franceses, os habitantes do império português não deviam ao governo gratidão alguma:

Logo, a abertura ou franqueza deste comércio, sendo uma medida que o governo adotou porque sem ela pereceria, podemos dizer que o fez porque assim lhe fazia conta, e não sei que o povo fique obrigado a tão estranha gratidão ao governo por este adotar uma linha de conduta que era necessária para conservar a sua existência como governo e como indivíduos. ${ }^{110}$

Três pontos de vista distintos sobre o mesmo tema, emanados de três diferentes lugares geográficos (mas não sociais) do Império. Três lugares diretamente interessados naquele debate: A nova Corte, o velho Reino e o principal parceiro comercial do Império. Na pena de Silva Lisboa, o que se pode observar é a defesa da nova política econômica da monarquia, da qual se estabelecia não apenas como um dos legitimadores, mas como um dos construtores, devido a sua posição dentro da administração do Império. Expressão do papel político da Impressão Régia do Rio de Janeiro: o de fornecer sustentação ao governo de D. João, como face cultural do seu projeto político. Na pena dos outros dois autores, a crítica a essa política econômica e, certamente, a expressão de projetos políticos alternativos para o Império português. Projetos políticos que não deviam ser divulgados no novo império português, como mostra a proibição da circulação do Correio Brasiliense em todo o Império Português, e a não publicação das obras econômicas de Acúrsio das Neves na América portuguesa. O que não as impedia, porém, de serem conhecidas na nova Corte, uma vez que, segundo anúncio na edição de 15 de abril de 1815 da Gazeta do Rio de Janeiro, o primeiro volume das Variedades podia ser encontrado na Loja da Gazeta. ${ }^{111}$

O que chama a nossa atenção para um aspecto interessante da atuação da

\footnotetext{
${ }^{109}$ COSTA, H. J. da. Correio Braziliense ou Armazém Literário. Dezembro de 1810, p. 608.

110 Ibid., p. 609.

${ }^{111}$ Gazeta do Rio de Janeiro, no ${ }^{\circ}$ 30, 15 de abril de 1815 .
} 
censura no Império português. Uma obra que não conseguisse licença da Junta Administrativa da Impressão Régia para ser editada pela tipografia, ainda podia circular no Rio de Janeiro, bastando para isso que fosse importada por algum livreiro aí estabelecido e conseguisse a sua liberação pelos Censores Régios do Desembargo do Paço, que atuavam no controle e fiscalização da entrada de livros na alfândega. Apesar de algumas vezes os mesmos homens atuarem nos dois órgãos, a sua atuação podia apresentar conflitos devido à ausência de critérios claros a serem seguidos. ${ }^{112}$ Para exercer o seu trabalho, os censores régios tinham necessariamente que ter acesso às obras proibidas, desde que elas não circulassem livremente entre o público geral. ${ }^{113} \mathrm{O}$ que revelava o caráter seletivo da censura no Império Português, que impunha limites para a posse e leitura de livros em conformidade com a desigualdade inerente a uma sociedade de tipo estamental. $\mathrm{Ou}$ seja, algumas pessoas podiam ler determinados livros e autores, que inversamente, eram proibidos para a maioria da população. O que nos leva a pensar que, ao fim e ao cabo, os censurados não eram os livros e sim os leitores. ${ }^{114}$

\footnotetext{
${ }^{112}$ Investigando o exercício da censura no período joanino, Leila Mezan Algranti mostrou como os censores régios podiam entrar, e entravam efetivamente, em desacordo com relação à liberação de determinada obra. No âmbito da disputa por honra e prestígio entre os "homens bons" do Paço, que utilizavam o cargo de censor régio como forma de autopromoção, esses conflitos serviam para chamar a atenção do monarca sobre a sua capacidade e competência: "Se na qualidade de "homens de corte' os censores régios tinham posturas semelhantes e não hesitavam em pleitear os frutos que acreditavam merecer por viverem sujeitos ao rei, como censores nem sempre agiam em concordância. Alguns costumavam ser extremamente severos, outros menos rigorosos, todos, porém, eram igualmente vaidosos de seu saber e sequiosos de se desincumbirem corretamente da difícil missão". ALGRANTI, L. M. Nos bastidores da censura: os "homens bons" do Paço, p. 233/234.

${ }^{113}$ A respeito da escolha para o cargo de censor régio, afirmam Lucia Bastos e Tânia Bessone que os escolhidos eram homens eruditos, possuindo amplo conhecimento da literatura da época, da biografia dos autores e dos acontecimentos históricos recentes. Homens esclarecidos que defendiam as ideias da Ilustração para a organização de uma nova sociedade, adaptando-as aos interesses de reformas conduzidas por um soberano esclarecido, mas que não aceitavam uma revolução nos moldes da ocorrida na França. NEVES, L. M. P. \& FERREIRA, T. M. T. B. da C. $O$ medo dos abomináveis princípios franceses: a censura dos livros nos inícios do século XIX no Brasil, p. 117

${ }^{114}$ Como explica Luiz Carlos Villalta, a Real Mesa Censória na época de Pombal, a Real Mesa da Comissão Geral para a Censura de Livros durante o reinado de D, Maria I e o Desembargo do Paço durante a regência e reinado de D. João VI, autorizavam algumas pessoas e instituições, excepcionalmente, a obter a autorização para possuírem livros proibidos. Na concessão de tais licenças, esses órgãos levavam mais em conta a categoria profissional dos requerentes do que sua inserção nos estamentos. Assim, teólogos obtinham licença para ler e possuir obras proibidas de teologia, mas não os advogados, aos quais eram permitidas exclusivamente a posse e a leitura de livros jurídicos defesos. Em suma: "Aos "ignorantes", facilmente sugestionáveis, gente a ser educada, deveria ser cerceado o acesso a determinados livros. Enquanto à elite intelectual constituída pelos "letrados conhecidos" e pelos religiosos em geral, grupo ao qual se integravam os próprios censores, acabava-se por conceder (...) a licença para possuir e ler livros proibidos".
} 
Essa "estamentalização-corporativização" da posse e leitura de livros, nas palavras de Luiz Carlos Villalta, é mais facilmente compreendida se atentamos para o significado de que se revestia o termo censura na virada do século XVIII para o XIX. Como explica Rui Tavares, o termo "censurar" não tinha, àquela altura, o significado fixo que veio adquirindo nos últimos séculos, mas sim portava uma amplitude semântica maior, sendo compreendido como sinônimo de "examinar" ou "criticar". Dessa forma, um livro censurado, que para nós evoca a ideia de um livro proibido ou expurgado, significava então um livro examinado ou apenas um livro que passou pelas mãos de um censor. ${ }^{115}$ Por isso, os censores deveriam ser homens eruditos, que tivessem conhecimento da obra que estavam examinando. Assim sendo, o caráter seletivo da censura garantia a circulação de obras consideradas perigosas dentro do Império português, assim como o embate de ideias entre aqueles que tinham permissão para ler essas mesmas obras.

\section{3.}

\section{As Manufaturas entre a liberação e os privilégios}

Em 1810 a Impressão Régia do Rio de Janeiro publicou, também da autoria de José da Silva Lisboa, as Observações sobre a franqueza da indústria e estabelecimento de fábricas no Brasil. Os principais livros de Silva Lisboa abordavam o tema da liberdade de instalação de manufaturas, estabelecida pelos alvarás de 1 de abril de 1808 (que revogava o alvará de proibição de manufaturas de 5 de janeiro de 1785) e de 28 de abril de 1809 (que estabelecia as medidas de incentivo julgadas necessárias para o desenvolvimento das manufaturas na América portuguesa, tais como a isenção de impostos e a concessão de privilégios). Nas citadas Observações sobre a prosperidade do Estado pelos liberais princípios da nova legislação do Brasil, Silva Lisboa já havia incluído o alvará de 1 de abril de 1808 entre as medidas dignas de elogio tomadas por D. João:

Entre os máximos benefícios da liberal legislação de S.A.R., deve-se contar o de permitir, pelo Alvará de 1 de abril de 1808, o estabelecimento neste Estado de todas as artes e manufaturas, e de toda a sorte de indústria, em pequeno e grande;

VILLALTA, L. C. Censura Literária e inventividade dos leitores no Brasil colonial, p. 67.

${ }^{115}$ TAVARES, R. Lembrar, Esquecer, Censurar, p. 152. 
revogando a proibição do sistema colonial seguido pelos mais governos da Europa que, por triste economia, tinham assim ordenado uma forçada divisão de trabalhos, concentrando a maior parte dos braços e fundos das colônias na agricultura, mineração e marinha (para cujos empregos, aliás, naturalmente a maior parte dos colonistas, de si mesmos e por muito tempo, tenderiam) só consentindo as ordinárias artes fabris, sem as quais é impossível haver cidade e progresso de civilização. ${ }^{116}$

Em artigo que analisa o alvará de proibição de manufaturas de 1785, explica Fernando A. Novais que essa lei expressava as contradições e dilemas da Ilustração portuguesa. Sua motivação principal era garantir a exportação da produção de tecidos portugueses para o Brasil. E para isso era necessário restringir as manufaturas coloniais, combater o contrabando e evitar o deslocamento da mão-de-obra da lavoura, da mineração e do processo de ocupação de novas áreas. ${ }^{117}$ Já no artigo que escreve juntamente com José Jobson Arruda, Novais complementa que a Metrópole passava por um momento de revitalização das atividades fabris e a questão sobre o modo como conciliar o desenvolvimento das manufaturas em Portugal com o bloqueio de atividades similares na Colônia se poria diante do talento de qualquer letrado que se pusesse a pensar a reconciliação possível entre dois mundos que se tornavam, gradativamente, antípodas. ${ }^{118}$

$\mathrm{Na}$ justificativa das Observações sobre a franqueza da indústria é possível perceber que a intenção do autor nessa obra é responder àqueles que reivindicavam maiores privilégios para a instalação de manufaturas na nova sede do Império. A insistência de Lisboa sobre o tema indica que a opinião contrária parecia ter muita força no próprio Império Português:

Depois da nova legislação do alvará de 1 de abril de 1808 , que deu franqueza à indústria deste Estado do Brasil, e do alvará de 28 de abril de 1809, que fixou os direitos e favores devidos aos industriosos eminentes, distintos e comuns, conciliando os recíprocos e indissolúveis interesses da mãe pátria e filha, é notório que não tem havido concórdia de opiniões sobre os meios mais oportunos para se animarem e promoverem os estabelecimentos de fábricas. ${ }^{119}$

A argumentação de Lisboa baseia-se em seis princípios, expostos no

\footnotetext{
${ }^{116}$ LISBOA, J. da S. Observações sobre a prosperidade do Estado pelos liberais princípios da nova legislação do Brasil, p. 54.

${ }^{117}$ NOVAIS, F. A. A proibição das manufaturas no Brasil e a política econômica portuguesa do fim do século XVIII, p. 223.

${ }_{118}^{11}$ NOVAIS e ARRUDA, op. cit., p. 232.

${ }^{119}$ LISBOA, J. da S. Observações sobre a franqueza da indústria e estabelecimento de fábricas no Brasil, p. 213.
} 
Prólogo das Observações sobre a franqueza da indústria: $1^{\circ}$ ) Em matéria de fábricas, era mais razoável seguir o exemplo do governo da América do Norte; $2^{\circ}$ ) O Brasil podia ainda por longo tempo ter muita indústria e riqueza sem estabelecer as fábricas refinadas e de luxo que distinguiam a Europa; $3^{\circ}$ ) As fábricas que mais convinham ao Brasil eram aquelas que se associavam à agricultura, comércio e navegação, e artes da geral acomodação do povo; $4^{\circ}$ ) Não convinha dar privilégios exclusivos aos que não fossem inventores e introdutores de novas máquinas e invenções nas artes; mas era razoável darem-se alguns especiais auxílios e favores aos primeiros introdutores das grandes máquinas e manufaturas de muito dispêndio; $5^{\circ}$ ) Toda a fábrica introduzida por espírito de rivalidade e abarcamento, no desígnio de diminuir a importação de fazendas estrangeiras, tende a diminuir a exportação e os mais proveitosos e já bem arraigados estabelecimentos deste Estado; e $6^{\circ}$ ) A estabilidade do princípio da franqueza da indústria, sendo subseqüente ao da franqueza do comércio, é meio eficaz de fazer introduzir e aperfeiçoar os mais úteis estabelecimentos, com maior rapidez e incessantemente progressiva energia pública para a opulência e população do Brasil.

Lisboa inicia a primeira parte das suas Observações sobre a franqueza da indústria recorrendo, mais uma vez, ao exemplo da política econômica dos Estados Unidos da América na intenção de mostrar que, assim como no caso do comércio, a indústria também seria regulada por uma ordem natural sobre a qual não conviria intervir por meio da concessão de privilégios ou incentivos por parte do Estado. ${ }^{120}$ As manufaturas estabelecidas de acordo com a ordem natural não necessitariam da concessão de privilégios, pois a mão invisível do mercado mostraria a necessidade que o comércio tem dos seus produtos e garantiria a sua prosperidade:

Quem for hábil e não temerário projetista de fábricas tem consigo o inauferível e natural privilégio exclusivo, que lhe dá a superioridade de sua indústria e capital, para excluir o competidor sem força nem injúria, servindo em suas obras melhor e mais barato ao público, este então espontaneamente o preferirá na compra e será

\footnotetext{
120 "Feitas as primeiras experiências e tentativas, o povo e o governo se desenganaram de quimeras; e reconhecendo este a ordem natural e irresistível força das coisas, não apoiou estabelecimentos de fábricas com os favores e privilégios que os governos da Europa praticam. Deixando os braços e capitais do país tomarem por si mesmo e de próprio acordo dos interessados, as direções mais apropriadas às circunstâncias da terra e indivíduos, procurando cada pessoa achar na geral indústria o próprio nível e o emprego mais conveniente e proporcionado a seu préstimo e fundo". Ibid., p. 219/220.
} 
constante freguês que, à porfia de outros compradores, lhe segurará extenso, progressivo e lucrativo mercado. ${ }^{121}$

Por outro lado, o perigo da intervenção do Estado concedendo privilégios que desrespeitassem a ordem natural seria o de estabelecer manufaturas para as quais o mercado e a sociedade ainda não estavam preparados, condenando ao fracasso as manufaturas assim estabelecidas:

Sem dúvida os governos, à força de privilégios e favores extraordinários, podem introduzir mais cedo do que cumpre, ou manter certas fábricas incôngruas nas circunstâncias do país que ainda está despreparado para indústrias superiores que demandam muitas artes e indústrias prévias e já assaz adiantadas e com abundante número de obreiros hábeis. Mas as obras de tais fábricas difícil ou forçosamente se sustentam. E são como as produções das estufas que, a muito custo e com pouco rendimento, mantêm em vegetação plantas exóticas. ${ }^{122}$

Portanto, era necessária uma correta utilização da política de concessão de privilégios, determinados no caso da América portuguesa pelo Alvará de 28 de abril de 1809, evitando aquilo que ele denomina de criação antinatural de manufaturas, contrária às determinações do sistema liberal de Economia Política. ${ }^{123} \mathrm{O}$ mais controverso dos sete artigos daquele alvará determinava o direito de privilégio exclusivo pelo tempo de 14 anos para os inventores e introdutores, no Império português, de alguma nova máquina. Enquanto deputado da Real Junta do Comércio, Agricultura, Fábrica e Navegação do Brasil, órgão responsável pela análise e concessão daquele privilégio, Lisboa procurava explicar os casos que em sua opinião deveriam ter direito a ele, separando os casos de invenção de novo maquinário dos de introdução de maquinário já utilizado em outros países. Praticamente toda a segunda parte da sua obra é dedicada a discutir a política de concessão de privilégios a partir do Alvará de 28 de abril de 1809:

Os governos modernos têm adotado a regra de premiar os felizes esforços do engenho humano, que produzem alguma invenção útil, dando aos inventores o

\footnotetext{
${ }^{121}$ Ibid., p. 226.

122 Ibid., p. 235.

${ }^{123}$ Nos seus Estudos do Bem Comum e Economia Política, Silva Lisboa volta ao tema, dedicando a ele toda a terceira parte da obra, dividida em duas seções, intitulada Teoria geral da indústria e do valor capital, redito, interesse e equidade dos empregos. Aí ele se refere a essa criação antinatural de manufaturas: "Há, também, pela política dos Estados modernos, uma divisão de trabalho menos natural, na qualidade ou na extensão, que é ocasionada por uma força indireta do governo quando, em boa intenção, considerando certos ramos de indústria preeminentemente vantajosos ao bem comum, dá especiais favores e privilégios aos que empregam seus capitais e braços em tais ramos". LISBOA, J. da S. Estudos do bem comum e economia política, p. 314.
} 
privilégio exclusivo temporário, para o desfruto da sua invenção. Principalmente merecem esta recompensa, e ainda mais algum outro prêmio extraordinário, os inventores de grandes máquinas de ajudar, abreviar e aperfeiçoar os trabalhos mais importantes da sociedade; pois o edifício da civilização deve a sua estabilidade, grandeza e formosura principalmente a tais inventores. Equiparar estes homens extraordinários e gênios superiores aos industriosos de outra ordem, ainda ativos e diligentes, que em mercenário patriotismo e só na mira do lucro fazem trespassar para outros países os inventos alheios, depois de já estarem patentes em todo o mundo, seria alinhar em ignominiosa equação pessoas de mui desproporcional predicamento. ${ }^{124}$

Segundo Silva Lisboa, em matéria de fábricas haveria duas escolhas igualmente fatais ao progresso e à fortuna particular e pública: "uma consiste em não se dar plena franqueza à indústria para estabelecimento de manufaturas, a outra consiste em introduzir estas por privilégios e favores extraordinários". ${ }^{125} \mathrm{~A}$ hidra dos exclusivos ("que tem mil cabeças e pulam e recrescem incessantemente, como as tênias e pólipos, quando não se cortam pelas entranhas vitais”) ${ }^{126}$ seria o perigo mais prejudicial ao desenvolvimento de fábricas, pois a concorrência desigual afastaria os empreendedores. Assim como no caso do comércio, a única exceção tolerada seriam as fábricas reais: "Fora dos casos marcados pela saudável legislação, só são justos os privilégios exclusivos em favor de fábricas reais de urgente interesse público". ${ }^{127}$

Como explica Tereza Cristina Kirschner, predominaria entre os deputados da Junta do Comércio a política de restrição à implantação indiscriminada de fábricas no Brasil. Temiam que um uso abusivo do direito de privilégio levasse a formação de monopólios particulares, que se opunham a ordem natural e ao alvará de 1 de abril de 1808. Explica a autora que a maior parte dos requerimentos de privilégio enviados para a Junta de Comércio provinha de negociantes de Portugal transferidos para o Brasil devido à invasão francesa do Reino, e que demandavam os mesmos privilégios concedidos às manufaturas portuguesas desde a época do Marquês de Pombal. Esses negociantes tinham como experiência anterior a política voltada para o fomento das manufaturas em Portugal, cuja característica foi a ampla concessão de privilégios, isenções e monopólios, com base nos princípios mercantilistas:

\footnotetext{
${ }^{124}$ LISBOA, J. da S. Observações sobre a franqueza da indústria e estabelecimento de fábricas no Brasil, p. 257.

${ }^{125}$ Ibid., p. 227/228.

${ }^{126}$ Ibid., p. 260.

${ }^{127}$ LISBOA, J. da S. Observações sobre a prosperidade do Estado pelos liberais princípios da nova legislação do Brasil, p. 62.
} 
É em um contexto marcado pela oposição aos antigos monopólios que se pode compreender os pareceres de José da Silva Lisboa e de outros deputados da Junta do Comércio contra a concessão indiscriminada de privilégios para a instalação de fábricas no Brasil. Houve uma política de incentivos e privilégios apenas para aquelas indústrias que tinham condições de se desenvolver independentemente da concessão de monopólios, ou seja, que pudessem se manter em uma situação de liberdade de comércio. ${ }^{128}$

Dos seis princípios defendidos por Silva Lisboa, os mais controversos talvez fossem aqueles que defendiam que as indústrias mais adequadas à América portuguesa eram aquelas associadas à agricultura e ao comércio, e que o Brasil podia, ainda por longo tempo, ter muita indústria e riqueza sem estabelecer fábricas refinadas e de luxo. Para defender esses princípios do ataque daqueles que pregavam a necessidade da instalação de manufaturas de produtos mais refinados, Silva Lisboa procura definir o termo indústria, chamando a atenção para a polissemia de que se revestia à época:

Como, na verdade, para se terem muitas e perfeitas manufaturas, é necessário que no país se tenham desenvolvido muitos e superiores graus de inteligência, pelo progresso da população e pela rivalidade de êmulos competidores em cada ramo e divisão de trabalho, daí se originou o aplicar-se como privativa e exclusivamente o termo indústria às mãos-de-obra das fábricas em grandes, e de objetos mais difíceis e complicados, quase se perdendo de vista toda a soma de indústrias e inteligências necessárias a extrair e transportar os produtos rudes da terra, ou manufaturá-los para os usos mais comuns da sociedade. ${ }^{129}$

O Dicionário da Língua Portuguesa de Antonio de Morais e Silva definia indústria como "Arte, destreza para granjear a vida; engenho, traça, em lavrar e fazer obras mecânicas, em tratar negócios civis". ${ }^{130}$ O termo mais adequado, utilizado no início do século XIX, para se referir ao que hoje denominamos indústria seria manufatura, definida por Morais como a fábrica e oficina de artefatos ou as obras feitas nela. Guardaria proximidade com o que então se denominava de fábrica. Sendo que esse último termo teria um sentido mais amplo, significando além de um lugar onde se trabalha e fabricam manufaturas; as rendas aplicadas às despesas da sacristia e reparos da Igreja (fábrica da sacristia ou da Igreja); o necessário para a construção de um edifício; o pessoal, animais de serviço, máquinas e provimentos para alguma obra ou empresa; projetos; ou o ato

\footnotetext{
${ }^{128}$ KIRSCHNER, op. cit., p. 167.

${ }^{129}$ LISBOA, J. da S. Observações sobre a franqueza da indústria e estabelecimento de fábricas no Brasil, p. 222.

${ }_{130}$ Ou ainda como advérbio de propósito, de indústria significaria de caso pensado. SILVA, A. de M. e. Dicionário da Língua Portuguesa, v.2, p. 153.
} 
de fazer alguma ação que demanda artifício, astúcia. ${ }^{131}$

Não obstante, Silva Lisboa parece utilizar o termo indústria indistintamente, algumas vezes como sinônimo de manufatura ou fábrica, e outras para ser referir à produção daquelas. A intenção do letrado bahiense era mostrar que o termo indústria não se referia somente às manufaturas mais refinadas, como comumente se compreendia, mas que existiam também outras formas de indústria mais adequadas à situação do Brasil: "Na verdade, o termo indústria deve ser aplicável a toda espécie de útil emprego de braços e capitais; e, com razão, se diz indústria rural, mineira, fabril, mercantil, náutica, etc". ${ }^{132}$ Esse ponto era de fundamental importância para a argumentação de Silva Lisboa, no sentido de rebater as críticas daqueles que o acusavam de anti-industrialista ou mesmo de fisiocrata. Dessa forma, Silva Lisboa não se opunha a uma economia baseada na indústria, mas acreditava que o estabelecimento de fábricas no Brasil era demasiadamente prematuro e inadequado ao quadro histórico brasileiro. Para ele, não se deveria desviar braços e capitais do comércio ou da agricultura, que deveria ser a principal indústria do Brasil, para a criação de manufaturas que fossem impróprias ou prematuras às circunstâncias locais. ${ }^{133}$ Sua intenção é alertar para o fato de que o abuso da política de concessão de privilégios teria o efeito de alterar essa determinação da ordem natural:

Por ora no Brasil, e ainda por longos tempos, a agricultura deve ser a nossa grande principal manufatura. As artes ordinárias, o comércio e a navegação dão ainda mais vasto e mais natural emprego aos braços e capitais do país. Estabeleçam-se as fábricas que as circunstâncias permitirem. Mas não convém que se façam, e menos que se autorizem, desvios do capital, por extraordinários favores do governo. ${ }^{134}$

\footnotetext{
${ }^{131}$ Ibid., v.2, p.1.

132 LISBOA, J. da S. Estudos do Bem Comum e Economia Política, p. 269. Dessa afirmação se depreende que, assim como Acúrsio das Neves, Silva Lisboa entendia a indústria como sendo constituída por manufaturas, agricultura e comércio.

133 “Consideremos que ainda estamos, por assim dizer, com o machado e a enxada na mão, lutando com desertos e matos. Colhamos, por ora, os produtos espontâneos que a natureza nos oferece. Ela é a nossa gratuita ou barata manufatureira [sic], e prepara a maior parte das obras e riqueza que precisamos". LISBOA, J. da S. Observações sobre a franqueza da indústria e estabelecimento de fábricas no Brasil, p. 222.

${ }^{134}$ LISBOA, J. da S. Observações sobre a prosperidade do Estado pelos liberais princípios da nova legislação do Brasil, p. 60. Lisboa já o havia enunciado nas suas Observações sobre o comércio franco do Brasil: "Tomando-se o termo indústria no sentido vulgar que o aplica às fábricas e, com especialidade, às de obras mais refinadas, que supõem conhecimentos superiores aos dos obreiros das artes comuns, chamadas mecânicas, deve-se ter por máxima certa e constante regra que só convém que se vá estabelecendo no Brasil tais indústrias lenta e gradualmente, passando-se das mais grosseiras para as de ordem mais elevada, começando-se pelas que proximamente se associam à agricultura que, por ora e ainda por longo tempo, deve, por assim
} 
Interessante notar a semelhança entre a argumentação de Lisboa e a justificativa utilizada no Alvará de 5 de janeiro de 1785 para se proibir a instalação de manufaturas na colônia. Fernando Novais sintetiza da seguinte forma a argumentação daquele Alvará:

A produção manufatureira colonial, disputando mão-de-obra às atividades primárias, faz decrescer a sua agricultura e mineração; isto reflete-se negativamente no comércio metropolitano cujo volume se restringe. Ora, sendo a verdadeira riqueza as produções da terra, justifica-se a proibição das manufaturas e restabelece-se a harmonia que se ia rompendo. ${ }^{135}$

José Acúrsio das Neves tinha uma opinião diferente da de Silva Lisboa, a respeito do tema da instalação de manufaturas. Como explicado no início do capítulo, ele considerava como única saída para a crise econômica que o Império atravessava o desenvolvimento da indústria, considerada nos seus três ramos: agricultura, manufatura e comércio. Porém, as manufaturas eram o ramo mais debilitado no panorama global de decadência e atraso de Portugal. Mas, também, era aí que se poderia atuar mais rapidamente e com melhores resultados. Como afirma Antonio Almodovar, para Acúrsio: "embora fôssemos atrasados enquanto país, éramo-lo muito mais enquanto país manufatureiro". ${ }^{136}$ A esse respeito, Acúrsio chama a atenção, na consulta da Real Junta do Comércio de 9 de dezembro de 1816, para a absoluta inexistência até aquele momento de maquinário a vapor em Portugal:

\begin{abstract}
É lastimoso o estado em que nos achamos a respeito de máquinas. Fazemos tudo à força de braços e de animais, enquanto nos outros países a força dos elementos quase dispensa a mão do homem nos trabalhos mais pesados, e aumenta prodigiosamente os frutos da indústria. Em uma grande parte da Europa e nos Estados Unidos da América, já os rios e até os mares se navegam pelo agente do fogo, sem mastros, sem velas e sem remos; e entre nós ainda se não acha estabelecida uma só máquina de vapor nas nossas fábricas. Enquanto não melhorarmos muito a esse respeito, serão baldados todos os esforços para competir com os estrangeiros. ${ }^{137}$
\end{abstract}

dizer, ser a nossa principal manufatura". LISBOA, J. da S. Observações sobre o comércio franco do Brasil, p. 149.

${ }_{135}^{135}$ NOVAIS, op. cit., p. 224

${ }^{136}$ ALMODOVAR, A. Texto e contexto: a questão dos privilégios de novo invento em José Acúrsio das Neves, p. 502.

${ }^{137}$ NEVES, J. A. das. Memória sobre os meios de melhorar a indústria portuguesa, considerada nos seus diferentes ramos, p. 173/174. 
Acúrsio se coloca, assim, na contramão das reflexões produzidas pelos letrados da Academia de Ciências de Lisboa, abordadas no início desse capítulo, denunciando o descaso com a industrialização do Reino, criticando a dependência econômica em relação à Inglaterra criada por esse descaso e elogiando amiúde as medidas tomadas durante o ministério de Pombal:

Quando o senhor Rei D. José subiu ao trono, achou a indústria em um abatimento incomparavelmente maior que o atual; porém o seu gênio, a atividade e firmeza do seu Ministro, sempre fecundo em recursos, tiraram a nação da sua apatia, e criaram fábricas, que fizeram a fortuna dos nacionais, e a inveja dos estranhos. Por morte deste Soberano deram-se alguns passos, que tendiam a fazer-nos retrogradar; porque como o Marquês de Pombal se tinha feito odioso pela sua nímia severidade, e caiu em desgraça, formou-se uma conspiração geral para destruir as magníficas obras do seu ministério. ${ }^{138}$

Pela sua ênfase na defesa da necessidade de instalação de fábricas no Reino, Acúrsio das Neves é considerado por Fernando Pinto Loureiro, um dos seus biógrafos, o precursor do industrialismo em Portugal. ${ }^{139}$ Ao contrário de Silva Lisboa, na sua defesa do desenvolvimento das indústrias do Reino, Acúrsio não considerava a concessão de privilégios exclusivos para novos inventos como um monopólio. Sua concessão não eliminaria a concorrência. Seria, antes, uma forma de promover a concorrência entre os produtores portugueses e, ao mesmo tempo, de se defender contra a concorrência estrangeira:

Conceder certas isenções e privilégios úteis aos fabricantes, aliviar de direitos e auxiliar com gratificações as manufaturas nacionais na sua exportação e consumo, e as matérias primas que lhes servem de base na importação, proibir ou carregar de grandes direitos as manufaturas estrangeiras, para não fazerem concorrência às nacionais, promover com iguais favores a introdução de máquinas úteis, estimular o espírito de invenção a fazer novos progressos, segurando aos inventores, por meio de privilégios exclusivos o aproveitarem-se de todo o fruto das suas descobertas por certo número de anos, são os expedientes que geralmente praticam as nações industriosas e não têm esquecido as nossas leis. ${ }^{140}$

Acúrsio das Neves discorda igualmente de Silva Lisboa, quanto ao privilégio a ser dado à agricultura em detrimento dos outros ramos da indústria.

\footnotetext{
138 Ibid., p. 115.

139 "O nosso economista não se limitou a exprimir teoricamente os problemas do nascimento da indústria moderna em Portugal, porque foi em todos os sentidos, o defensor dessa mesma indústria: por escritos, e por atos, nas suas obras e em decisões oficiais (na Junta do Comércio e na Real Fábrica das Sedas); defensor contra os mercantilistas e contra os fisiocratas, defensor no terreno econômico, e no plano jurídico, no campo da tecnologia e no da política tributária". LOUREIRO, F. P. José Acúrsio das Neves: precursor do industrialismo em Portugal, p. 21.

140 NEVES, J. A. das. Variedades sobre objetos relativos às artes, comércio e manufaturas, consideradas segundo os princípios da economia política, v.1, p. 129/130.
} 
Argumenta esse autor que manufaturas e agricultura se apoiariam mutuamente, em vez de entrarem em conflito pela disputa da mão-de-obra disponível:

Mas as fábricas não são inimigas da agricultura: pelo contrário, são elas as que lhe dão uma atividade que por nenhum outro gênero de fomento poderia obter. Bem longe de lhe roubarem os braços necessários, elas ajuntam à roda de si uma povoação numerosa, que não só trabalha mas aumenta o valor aos produtos do trabalho. (...) não há país em que floresçam as manufaturas no qual, ao mesmo tempo, não prospere a agricultura; assim como se não mostrará um só canto da terra sem indústria fabril que seja bem cultivado e povoado. São duas rodas que engrenam: uma move a outra. ${ }^{141}$

Apesar de afirmar textualmente que "não há civilização sem o simultâneo concurso da agricultura, artes, comércio", ${ }^{142}$ Silva Lisboa parece ter sido interpretado pelos seus contemporâneos como um fisiocrata, um defensor da agricultura como a verdadeira fonte de riqueza dos Estados. Porém, como chamam a atenção Fernando Novais e José Jobson Arruda, ao pensar a situação das fábricas no Brasil, Silva Lisboa pensa-as conjuntamente com a situação das fábricas reinóis, como partes integrantes de um mesmo espaço econômico. ${ }^{143}$ Assim sendo, a sua ressalva à instalação de manufaturas no Brasil não se estendia necessariamente a Portugal. Pelo contrário, da lista de pré-requisitos indispensáveis para a instalação de manufaturas que elabora, pode-se chegar a conclusão que as fábricas deveriam se concentrar onde a terra era mais escassa e a mão-de-obra mais abundante, ou seja, em Portugal. Os pré-requisitos indispensáveis para a instalação de manufaturas seriam, segundo Silva Lisboa: $1^{\circ}$ ) capitais disponíveis; $2^{\circ}$ ) vasta população; $3^{\circ}$ ) abundância de subsistência e de matérias-primas; $4^{\circ}$ ) demanda do país; $5^{\circ}$ ) superioridade aos estrangeiros em barateza e perfeição de obra; $6^{\circ}$ ) difusão de inteligência; $7^{\circ}$ ) franqueza do comércio e indústria; $8^{\circ}$ ) privilégios, prêmios e honras aos inventores nas artes e ciências. Apesar de não admitir explicitamente, fica claro da leitura da obra de Lisboa que, para ele, o Brasil só satisfazia a um desses pré-requisitos, o da abundância de matérias-primas. ${ }^{144}$

Na curta resenha que escreveu no Correio Braziliense sobre as Observações

\footnotetext{
${ }^{141}$ NEVES, J. A. das. Variedades sobre objetos relativos às artes, comércio e manufaturas, consideradas segundo os princípios da economia política, v. 2, p. 219/220.

${ }^{142}$ Silva Lisbo LISBOA, J. da S. Observações sobre a franqueza da indústria e estabelecimento de fábricas no Brasil, p. 286.

${ }_{143}^{143}$ NOVAIS e ARRUDA, op. cit., p. 237.

${ }^{144}$ LISBOA, J. da S. Observações sobre a franqueza da indústria e estabelecimento de fábricas no Brasil, p. 236.
} 
sobre a franqueza da indústria e estabelecimento de fábricas no Brasil, Hipólito da Costa critica, entre outras coisas, a argumentação de Silva Lisboa sobre a impossibilidade da instalação de indústrias na América portuguesa devido à ausência desses pré-requisitos: “O autor parece dizer: não há ciências no Brasil, logo não tenhamos fábricas; e nós lhe retorquimos assim: não há ciências no Brasil, logo introduzam-se e favoreçam-se os homens sábios, para termos fábricas". 145

Para Silva Lisboa, porém, o maior obstáculo ao estabelecimento de manufaturas na América Portuguesa não seria econômico, e sim social: o predomínio da mão-de-obra escrava. Como explica Tereza Cristina Kirschner, a crítica à escravidão evoluiu, ao longo do século XVIII, de um humanismo crítico à violência praticada contra os escravos para um discurso baseado nos princípios da economia política, no qual o escravo era considerado menos produtivo do que o homem livre. ${ }^{146}$ Sendo a maior parte da sociedade composta por negros e escravos, moral e intelectualmente inferiores, não seria capaz de trabalhar em indústrias mais complexas:

A sua [do Brasil] população principal é de escravos e a de brancos e gente livre é pequena e avança muito lentamente pela desgraçada lei do cativeiro e comércio da costa da África, que dificulta os casamentos das pessoas de extração européia, e obsta a formar-se um corpo de nação homogêneo e compacto. Convém-lhe, pois, pela necessidade das coisas, o trabalho dos campos e das artes comum [sic], visto que a óbvia e fácil colheita dos produtos rudes da terra, e o simples fabrico e transporte de obras grosseiras ou ordinárias, está mais na possibilidade e esfera da parte principal do povo. ${ }^{147}$

Lisboa volta ao assunto com mais vagar nos Estudos do bem comum e Economia Política. Segundo Rocha, a partir dessa obra "a incompatibilidade entre escravidão e indústria tornou-se o eixo das suas considerações sobre a escravidão". ${ }^{148}$ Nesta obra ele reconhece a necessidade da abolição da escravidão como pré-requisito para o desenvolvimento das manufaturas, uma vez que a

${ }^{145}$ COSTA, H. J. da. Correio Braziliense ou Armazém Literário. Dezembro de 1810. p. 618. Assim como fez na sua resenha das Observações sobre o comércio franco do Brasil, Hipólito inicia essa resenha também pela invalidação da comparação com os EUA: "Decididamente não podemos admitir a comparação dos Estados Unidos como fazendo argumento para o Brasil. A indústria prospera em um país livre, à sombra da proteção da liberdade, e não vigora em um país despótico, sendo iguais outras circunstâncias, em consequência da opressão do despotismo”. Ibid., p. 615.

${ }_{146}$ KIRSCHNER, op. cit., p. 187.

${ }^{147}$ LISBOA, J. da S. Observações sobre a franqueza da indústria e estabelecimento de fábricas no Brasil, p. 221.

${ }^{148}$ ROCHA, A. P. A Economia Política na Sociedade Escravista, p. 130. 
escravidão produzia a "inércia" dos setores produtivos, tornando-os apegados a métodos primitivos de produção e resistentes a inovações:

Os soberanos dos mais cultos Estados da Europa já há séculos reconheceram ser do próprio interesse, bem entendido, não menos que do Bem Comum dos povos, a abolição do cativeiro doméstico e ainda da servidão da gleba, com que se forçava aos paisanos morar nas terras dos grandes senhores, para o serviço de suas pessoas e herdades. Os reinos em que plenamente se adotou o justo sistema são distintos por superior indústria e conseqüente riqueza e civilização, a respeito dos que ainda conservam restos do antigo barbarismo e governo feudal. ${ }^{149}$

Segundo Penalves Rocha, apesar de reputar a escravidão como algo nocivo à economia e à sociedade, esta seria apenas a atitude intelectual de Silva Lisboa, não se encontrando na sua obra uma argumentação abolicionista. ${ }^{150} \mathrm{Na}$ prática, ele considerava impossível abolir a escravidão, pois a tinha na conta de uma instituição ajustada às necessidades imediatas da América portuguesa. Esse aparente paradoxo se resolveria pela diferenciação entre Economia Política e Ciência da Política, estabelecida por Lisboa nos seus Estudos do Bem Comum e Economia Política. Embora intimamente relacionadas, a primeira apresentaria uma esfera mais restrita: enquanto o objetivo da Política era prover a segurança, independência e força do Estado, o da Economia Política seria promover a indústria e a riqueza nacional. ${ }^{151}$ Dessa forma, por um lado, enquanto economista, ele se sentiria no direito de acusar a escravidão por obstruir o progresso, e condená-la moralmente, rejeitando o argumento do mal necessário; por outro lado, a sua abolição dependeria da província da política, que não era da sua competência. Como explica Penalves Rocha: "É como se ele informasse seus leitores de que não lhe cabia lutar pela implantação do trabalho livre, embora reconhecesse seus benefícios econômicos". ${ }^{152}$

A argumentação de Silva Lisboa contra a concessão de privilégios exclusivos para a instalação antinatural de manufaturas que seriam inadequadas às condições da América portuguesa encontra sua coroação na defesa do $5^{\circ}$ e $6^{\circ}$ princípios, onde ele se insere no debate de um tema discutido no Império português, pelo menos, desde o fim do século XVII: a defesa da introdução de

${ }^{149}$ LISBOA, J. da S. Estudos do Bem Comum e Economia Política, p. 370. Nessa mesma obra, Silva Lisboa parece deixar claro, pela primeira vez, a sua posição a respeito do tema: "Não insisto neste melindroso assunto, que entra na província da política; só protesto contra o apregoado absurdo que no Brasil o sistema do cativeiro é mal necessário". Ibid., p. 371.

${ }^{150}$ ROCHA, A. P. A Economia Política na Sociedade Escravista, p. 126.

${ }^{151}$ LISBOA, J. da S. Estudos do Bem Comum e Economia Política, p. 173

${ }^{152}$ ROCHA, A. P. A Economia Política na Sociedade Escravista, p. 131. 
manufaturas no Reino como forma de diminuir a importação de produtos manufaturados e a consequente saída de capitais do Reino e do Império. A atenção dedicada por Silva Lisboa ao assunto nos mostra que, apesar de antigo, o debate ainda não havia atingido um consenso no início do século XIX. Na sua objeção a essa idéia, Lisboa retoma todos os principais pontos da sua argumentação a favor da liberdade de comércio e de indústria. Antes de qualquer coisa, as fábricas introduzidas por espírito de rivalidade e abarcamento, seriam contrárias não apenas à ordem natural, mas também à Civilização, uma vez que desrespeitando a divisão natural do trabalho teriam por consequiência diminuir o trato comercial entre os homens:

É absurdo introduzir e multiplicar no Brasil, e prematuramente, as fábricas de imitação da Europa para se afetar a independência do comércio e indústria dos Estados estrangeiros. Isso é contrário à evidente economia do Regedor do Universo, que fez os homens essencialmente sociais, constituindo por isso todos os povos unidos e dependentes uns dos outros pelo comércio, variando climas, produtos, localidades e circunstâncias, a fim de sustentar-se o trabalho e a geral indústria em todas as regiões, e nas direções mais produtivas e proporcionadas às vantagens privativas de cada Estado e, consequentemente, bem se manter e adiantar a harmonia, civilização e perfetibilidade do gênero humano. ${ }^{153}$

Esse expediente seria, antes, prejudicial à economia do Império, pois desviaria braços das outras atividades produtivas mais adequadas à América portuguesa:

Se cortássemos estas relações e a sua franqueza, com prepóstera introdução de manufaturas menos adaptadas às nossas circunstâncias, seríamos as vítimas das nossas vaidades, ciúmes e espírito de abarcamento; e sentiríamos o rápido retrocesso da nossa agricultura, comércio e navegação com ela ligada, perdendo-se ou muito proporcionalmente diminuindo-se grandes ramificações de indústrias, para que aliás temos mais naturais oportunidades. ${ }^{154}$

Por fim, aquele expediente se apresentava a Silva Lisboa como um despropósito uma vez que se deveria, antes, estimular o comércio com as outras nações como forma de conseguir para o Império aquilo de que tinha carência, em vez de se pensar em evitar a saída do capital, o que, ao fim e ao cabo, seria mesmo impossível:

Era impossível acumular e reter no Brasil a quantidade de ouro que todos os anos se extrai de nossas minas. Eu me comprazeria de ver trocadas as nossas

\footnotetext{
${ }^{153}$ LISBOA, J. da S. Observações sobre a franqueza da indústria e estabelecimento de fábricas no Brasil, p. 277/278.

${ }^{154}$ Ibid., p. 286.
} 
superabundantes peças de dinheiro em muitas peças de artilharia, bons armamentos de todas as qualidades, muitas excelentes máquinas dos trabalhos que mais nos conviessem, muitos mestres de agricultura, artes e ciências que, com superabundante honesta usura, nos reporiam o valor do ouro que déssemos em câmbio de seus serviços, não menos estimáveis e de superior serviço que os chamados metais preciosos. ${ }^{155}$

A idéia contrária, porém, ainda encontrava muitos defensores entre os letrados nos dois lados do Atlântico português. Um dos quais, muito provavelmente, o redator de O Patriota, Manuel Ferreira de Araújo Guimarães, que publicou no seu periódico duas memórias sobre o tema, datadas do final do século XVII e da primeira metade do século XVIII. Apesar de não virem acompanhadas de nenhum comentário do redator, as duas memórias defendem o estabelecimento de indústrias como forma de diminuir a saída de capitais do Reino pela importação de manufaturados. Logo no primeiro número do periódico, foi publicado um parecer de Alexandre de Gusmão enviado a D. João V, intitulado Cálculo sobre a perda do dinheiro do Reino. ${ }^{156} \mathrm{O}$ autor inicia a sua curta memória identificando uma situação de crise provocada pela incapacidade de Portugal de manter dentro do seu Império os metais preciosos extraídos na sua colônia da América:

Senhor, o dinheiro é o sangue das monarquias, e extraído do corpo delas enfraquecem, da mesma sorte que acontece aos corpos humanos quando se lhe tira o sangue. A este modo de fraqueza se vai reduzindo Portugal, pois que tanto se trabalha em extrair-lhe a moeda, quanto ele caminha para a pobreza e, por conseqüência, para a ruína. ${ }^{157}$

No pensamento de Gusmão aparece aquela mesma divisão natural do trabalho aludida por Silva Lisboa e a consequente necessidade do estabelecimento de relações comerciais. Considera, porém, que esse comércio deveria ser executado, idealmente, pela troca equivalente de gêneros, constituindo-se a troca de gêneros por moeda o pior de todos os tipos de comércio, o que ele denomina de comércio passivo:

Os povos, Senhor, para viverem em todas as terras do Reino, necessitam fornecer-

\footnotetext{
${ }^{155}$ Ibid., p. 282.

156 Natural de Santos, Alexandre de Gusmão (1695- 1753) foi conselheiro do Conselho Ultramarino e secretario de D. João V entre 1730 e 1750. É mais lembrado pela historiografia pela sua participação na assinatura do Tratado de Madri (1750). A memória não está datada, mas seguramente foi escrita nesse período.

${ }^{157}$ GUSMÃO, A. de. Cálculo sobre a perda do dinheiro do Reino. O Patriota. janeiro de 1813, p. 101.
} 
se uns aos outros de gêneros e manufaturas que todos hão mister para o sustento e trato da vida; o que sempre executam pelo meio sabido do comércio; e como os gêneros e manufaturas dos povos, sejam nacionais ou estrangeiros, não podem expor-se em todas as partes, com a facilidade com que transportam o dinheiro, que igualmente representa os mesmos gêneros e manufaturas, por isso se estabeleceu a moeda. Assim, pois, continua o comércio fazendo-se de gêneros, suprindo-se estes e aqueles com o dinheiro, quando os não há igualmente de ambas as partes, para fazer-se a balança do comércio nos gêneros e manufaturas de que uns e outros necessitam. (...) Assim nos acontece em Portugal, de que certamente resulta fazermos comércio passivo, que é o pior de todos, porque pagamos sempre com dinheiro a balança dos gêneros e manufaturas que não temos, e de que muito necessitamos. ${ }^{158}$

Essa situação, aliada à diminuição do rendimento das minas do Brasil, levava à situação de crise diagnosticada pelo autor. A partir da qual ele fazia algumas recomendações ao Rei, objeto principal da sua memória:

E, como seja do Ministério dos Soberanos procurar pela conservação e felicidade dos povos que se confiaram no seu governo, suplicam os portugueses, fiéis vassalos de V.M., com a maior submissão e respeito diante do Real Trono, que V.M. seja servido: Que se aumente a Nobreza bem entendida. Que diminua o Luxo com alguma lei suntuária. Que se aumente a agricultura, fazendo-se as estradas e cortando-se as ribeiras para navegar e regar. Que se estabeleçam fábricas, aumentando-se por toda a parte a indústria. E que, finalmente, se favoreça o comércio dentro e fora do Reino, sem o qual não pode haver Estado rico, poderoso, nem florente. ${ }^{159}$

Alguns meses depois, O Patriota publicou outra memória, mais antiga e mais elaborada, sobre o assunto: o Discurso do doutor Duarte Ribeiro de Macedo sobre a introdução das artes no Reino, que escreveu sendo enviado na corte de Paris no ano de $1675 .{ }^{160} \mathrm{O}$ ponto de partida da argumentação de Macedo é o diagnóstico do estado deplorável das relações comerciais com o exterior, que se expressava pelo escoamento do dinheiro do Reino. Assim como Gusmão, Macedo também utiliza a metáfora biológica do dinheiro como sangue do Reino, mas diferentemente daquele atribui maior importância à circulação desse sangue:

Diz-me V.M. que está lastimoso o comércio do Reino porque as nossas mercadorias (por falta de valor) não têm saca; e que os estrangeiros, para se

\footnotetext{
${ }^{158}$ Ibid., p. 102.

159 Ibid., p. 106/107.

${ }^{160}$ Duarte Ribeiro de Macedo (1618-1680) iniciou a sua carreira política na administração do império como juiz de fora em 1650, em Elvas, sendo depois corregedor em Torre de Moncorvo, em 1656, e desembargador da Relação do Porto, em 1659, foi embaixador português junto às cortes de Paris, Madri e Turim. É considerado por José Luis Cardoso um dos três autores mais representativos do pensamento econômico português da Época da Restauração (CARDOSO, J. S. O Pensamento econômico na época da Restauração, p. 135). A memória de Duarte Ribeiro de Macedo foi publicada em três partes durante três números consecutivos do periódico: agosto, setembro e outubro de 1813.
} 
pagarem das que metem no Reino, levam o dinheiro. Mal é este que pede remédio pronto, porque se continua perder-se-hão as conquistas e o Reino: as conquistas porque a sua conservação é dependente do valor dos frutos que nelas se cultivam; e se não tem valor, não tem gasto nem se podem comutar pelo infinito número de gêneros que os moradores delas necessitam. O Reino porque o dinheiro é o sangue das Repúblicas, e sucede no corpo político com a falta de dinheiro o mesmo que sucede no corpo físico com a falta de sangue. Sem dinheiro e sem comércio poderão viver os homens, mas da mesma sorte que vivem os índios no Brasil e os negros na África, dos frutos rústicos e naturais, mas sem sociedade civil, que é o que os distingue das feras. ${ }^{161}$

Duarte Ribeiro alude a uma diminuição do rendimento da produção colonial, no final do século XVII, não tanto pela queda nos preços do açúcar que se verificava naquele momento, mas principalmente pela perda do comércio da Índia, devido ao encolhimento do império português no Oriente, frente às investidas das Companhias das Índias Orientais holandesa e inglesa. ${ }^{162}$ Ele propõe uma divisão da história do Império português em três momentos para provar que aquela situação de crise não era antiga:

É necessário considerar três tempos no Reino: um antes que passamos a Índia, outro enquanto fomos senhores do comércio dela, e o último depois que a perdemos. (...) No primeiro tempo não houve este dano porque naquela idade (a que podemos chamar de ouro) não entravam no Reino fazendas estrangeiras, principalmente das que dependem da arte. E como o Reino era mais abundante de frutos de que os estrangeiros necessitavam, era muito mais o que tinha que dar do que o que deles recebia. (...) No segundo tempo, que é o das conquistas (glorioso sim, mas em que se perdeu a moderação dos primeiros séculos) abrimos as portas às riquezas do Oriente, que fizeram o Reino abundante e rico, e seguiu-se o luxo, companheiro inseparável da riqueza. (...) Abrimos também as portas às fazendas estrangeiras, e meteram os estrangeiros neste Reino tudo o que a arte e luxo tinha descoberto nos outros. Ainda assim nos não levaram dinheiro, porque como éramos senhores de todas as drogas e riquezas do Oriente, tínhamos muito mais que dar o que recebíamos, e daqui nascia ser Portugal o mais rico reino e Lisboa a mais rica praça do Mundo. (...) O terceiro tempo, depois da perda do comércio da Índia, é o em que contraímos a enfermidade mortal que hoje padece o nosso comércio, porque nós necessitamos de todas as coisas que introduziram as riquezas da Índia, com que as pagávamos. Donde se segue que pagamos em dinheiro aos estrangeiros o que excede o que nos dão ao preço das fazendas e drogas que nos levam. ${ }^{163}$

\footnotetext{
${ }^{161}$ MACEDO, D. R. de. Discurso do doutor Duarte Ribeiro de Macedo sobre a introdução das artes no Reino, que escreveu sendo enviado na corte de Paris no ano de 1675. O Patriota. Agosto de 1813 , p. 41.

${ }^{162}$ Como explicam Arno e Maria José Wehling, os preços do açúcar despencaram entre 1640 e 1700 devido à concorrência do açúcar produzido nas Antilhas por holandeses e ingleses (WEHLING, A; WEHLING, M. J. C. de . Formação do Brasil Colonial, p. 142). Na conjuntura das guerras de restauração da monarquia de Bragança, Portugal se viu obrigado a assinar onerosos tratados por meio dos quais cedeu Tânger e Bombain à Inglaterra. A esse respeito ver BOXER, C. R. O Império Marítimo Português, p. 141 a 163.

${ }^{163}$ MACEDO, D. R. de. Discurso do doutor Duarte Ribeiro de Macedo sobre a introdução das artes no Reino, que escreveu sendo enviado na corte de Paris no ano de 1675. O Patriota. setembro de 1813, p. 34/35/36.
} 
A saída encontrada pelo autor para essa situação seria a introdução das manufaturas no Reino. O que seria, segundo sua argumentação, mais útil e necessário a Portugal do que a qualquer outra nação da Europa, devido a posição privilegiada do seu porto, capaz de distribuir a sua produção por toda a Europa e América. Na conclusão da sua memória ele lista todos os benefícios que adviriam da introdução das manufaturas no Reino:

Seremos muitos em número, única felicidade das monarquias. Cultivaremos uma terra fertilíssima, que há de pagar os benefícios que lhe fizermos com abundantes frutos. Teremos gente para a guerra, para as colônias, para as armadas, e daremos ocupação aos sujeitos e desterraremos da República a ociosidade, mortal inimiga da sociedade civil. Faremos Lisboa o mais rico empório do mundo; depósito e escolha de todo o comércio deles. Crescerá o patrimônio real com maior número e maior riqueza dos vassalos. Não se rirão de nós os estrangeiros, que comumente nos estimam por índios da Europa. ${ }^{164}$

No primeiro volume dos seus Estudos do Bem Comum, publicado em 1819,

José da Silva Lisboa não deixou de comentar o Discurso de Duarte Ribeiro de Macedo, reeditado sete anos antes por O Patriota, discordando daquele autor quanto às causas da decadência econômica do Reino no final do século XVII, que ele atribui exclusivamente ao período de domínio espanhol sobre Portugal e à longa guerra de restauração:

Pois que todo se dirige a convencer que a decadência da riqueza nacional, então existente, procedia da saída dos metais preciosos do Reino. E considerou que a Introdução das Artes era o único remédio deste mal. Sem dúvida, tinha em vista as artes superiores, pois que reconhecia que em Portugal havia grande número de artistas dos ofícios ordinários, que passavam a Castela. Admira que tão perspicaz estadista não advertisse nas principais causas óbvias de decadência da riqueza nacional: $1^{\text {a }}$ na sujeição, por mais de meio século, à Espanha; $2^{\mathrm{a}}$ estrago de capitais produtivos pela tão longa guerra de restauração. ${ }^{165}$ [Grifo meu]

A crítica de Lisboa ao Discurso de Duarte Ribeiro baseava-se no argumento

\footnotetext{
${ }^{164}$ Ibid. O Patriota. outubro de 1813, p. 47.

${ }^{165}$ LISBOA, J. da S. Estudos do Bem Comum e Economia Política, p. 106. Nessa passagem, Lisboa nitidamente se equivoca, deliberadamente ou não é difícil dizer, pois que Macedo expressa textualmente que ele se referia ao desenvolvimento no Reino de indústrias de uso comum: "As do uso comum são as mais fáceis de obrar e as mais necessárias ao Reino, e as que inculco para o fim a que se encaminha este papel. Não digo que se procure a introdução das mais difíceis, que façamos logo fábricas de brocados, tapeçarias e outras coisas semelhantes, suposto que fora utilíssima a introdução de todas, como mostra este discurso. A introdução das artes mais comuns é mais fácil nas terras onde há os materiais que nas terras onde faltam. E, por conseqüência, mais fácil entre nós que entre os estrangeiros. Todos sabemos que no Reino e nas conquistas há abundância de lãs, linho e algodão, e todos os materiais que servem às tinturas, e não há abundância de sedas, por falta de aplicação, como direi em outro lugar". O Patriota, setembro de 1813, p. 40/41.
} 
de que, movendo-se ainda dentro dos limites do mercantilismo, o pensamento econômico daquele autor demonstrava como principal preocupação a manutenção de uma balança comercial favorável:

$\mathrm{O}$ autor, de puro patriotismo, seguiu as opiniões estabelecidas e pretendeu enriquecer a nação desejando concentrar no Reino os metais preciosos e todas as artes e fábricas, para que o ouro e a prata não saiam do Estado, nem vão [sic] vivificar as indústrias das mais nações. É impossível tão sinistro abarcamento, pois que nenhuma nação pode ter braços e capitais para toda a espécie de manufaturas. ${ }^{166}$

Apesar de separados por quase um século e meio, os dois autores parecem estabelecer um diálogo. O que significa dizer que não apenas Silva Lisboa replicava a argumentação de Duarte Ribeiro de Macedo, mas também que este comentava argumentos que seriam re-utilizados por Silva Lisboa cento e quarenta e cinco anos depois, mostrando que se a questão não era nova, tão pouco o eram os argumentos de Silva Lisboa. Talvez tenha sido justamente a sua capacidade de dialogar com as obras mais recentes de Economia Política, apesar do seu distanciamento temporal, o motivo pelo qual Manuel Ferreira de Araújo Guimarães tenha escolhido reeditar justamente o Discurso de Duarte Ribeiro em 1813. Por exemplo, ao perguntar-se sobre se haveria algum inconveniente do desenvolvimento das manufaturas no Reino, Duarte Ribeiro nos faz ver que à sua época já era corrente um dos principais argumentos de Lisboa:

O primeiro inconveniente que se considera e que é comum entre os nossos ministros é dizer: se introduzimos as artes, não terão saída as nossas drogas, que os estrangeiros buscam a troco das suas manufaturas, e perderemos as conquistas que só com a saída delas se conservam; e a Fazenda Real o direito das alfândegas. ${ }^{167}$

Por fim, no Discurso de Duarte Ribeiro também é possível encontrar a crença naquela divisão natural do trabalho, que embasa a argumentação de Silva

\footnotetext{
${ }^{166}$ LISBOA, J. da S. Estudos do Bem Comum e Economia Política, p. 109.

167 MACEDO, D. R. de. Discurso do doutor Duarte Ribeiro de Macedo sobre a introdução das artes no Reino, que escreveu sendo enviado na corte de Paris no ano de 1675. O Patriota. setembro de 1813 , p. 43. Hipólito da Costa também critica a argumentação utilizada por Silva Lisboa nas Observações sobre a franqueza da indústria, sobre a diminuição das importações e a consequente diminuição na arrecadação dos impostos: "Porque diz o autor que da introdução das fábricas do país resultaria o perder o Estado os direitos que percebe das manufaturas estrangeiras. Mas quem paga esse direito de importação? O consumidor do artigo importado, visto que o vendedor acrescenta no preço o que pagou de direitos. Logo, o Estado pode cobrar esse direito do consumidor, quer a manufatura venha do estrangeiro quer seja trabalhada no Brasil. E, portanto, não vemos porque seja o Estado obrigado a perder essa renda; e, além de não perder esses direitos, ganha o dar emprego e ocupação a todas as pessoas que se empregam na fábricas”. COSTA, H. J. da. Correio Braziliense ou Armazém Literário. Dezembro de 1810, p. 617.
} 
Lisboa a respeito da franqueza de comércio e de indústria. A idéia, pelo jeito, já contava com uma história centenária à época em que Silva Lisboa escreve suas obras de Economia Política:

A Providência Divina, cuidadosa da mútua correspondência dos homens e da sociedade civil das nações, não deu a uma só todos os bens da natureza. A todas as nações repartiu a produção pela diversidade dos climas, para que a necessidade que uns têm do que os outros produzem facilite o comércio e o trato entre os homens; levando uns e trazendo outros o de que necessitam todos. Daqui se segue que não há província tão abundante que não tenha necessidade dos frutos alheios, e nenhuma tão pobre e tão estéril que não tenha que mandar às abundantes. ${ }^{168}$

Porém, apesar de partirem do mesmo princípio, na continuação da sua argumentação Duarte Ribeiro de Macedo chega à conclusão diametralmente oposta a de Lisboa: "Mas a indústria e entendimento repartiu igualmente a todas as nações, fazendo a todas capazes das operações da arte; e se faltam em algumas é por falta de uso e da política e não da capacidade". ${ }^{169}$

Dessa forma, a questão da liberdade de indústria, na pena de Silva Lisboa servia, assim como no caso da sua defesa da liberdade de comércio, para justificar e legitimar a política econômica do Príncipe Regente, consolidada nos alvarás de 1 de abril de 1808 e de 28 de abril de 1809 . Assim como para justificar a restritiva política de concessão de privilégios adotada pela Real Junta do Comércio. Pois, a franqueza de indústria não deveria se opor à franqueza de comércio, principal característica da política econômica do Império Português após 1808, no pensamento de Silva Lisboa. Como sintetiza Maria Beatriz Nizza da Silva: "Franqueza de indústria não significava de modo algum industrialização forçada, mas sim a livre concorrência das atividades fabris nacionais com os produtos manufaturados estrangeiros". ${ }^{170}$ Baseado no seu conhecimento de História Natural e do grande potencial econômico que representavam os recursos naturais do Brasil, segundo Silva Lisboa a principal atividade econômica a ser estimulada no Império deveria ser a agricultura, para que os produtos da indústria agrícola pudessem ser trocados pelos produtos manufaturados estrangeiros. Dessa forma, segundo seu pensamento, a economia do Império poderia se beneficiar das políticas de liberdade de indústria e liberdade de comércio, que não entrariam em

\footnotetext{
${ }^{168}$ MACEDO, D. R. de. Discurso do doutor Duarte Ribeiro de Macedo sobre a introdução das artes no Reino, que escreveu sendo enviado na corte de Paris no ano de 1675. O Patriota. setembro de 1813, p. 45

${ }^{169}$ Ibid.

${ }^{170}$ SILVA, M. B. N. da, op. cit., p. 124.
} 
concorrência. Ficavam excluídos dessa legitimação da política econômica de D. João, obviamente, as pressões e os interesses estrangeiros, ressaltados pelos seus opositores.

$$
* * *
$$

Os trabalhos sobre Economia Política produzidos por letrados portugueses, dentro ou fora do Império português, ao longo das primeiras décadas do século XIX, talvez sejam a forma mais explícita de expressão daquela relação entre saber e poder que procuramos ressaltar nesse trabalho ao abordar a produção de Impressão Régia do Rio de Janeiro. A intenção desse capítulo foi chamar a atenção para esses trabalhos na medida mesma em que eles nos permitem sublinhar o papel político da tipografia estabelecida por D. João diante das tensões existentes no interior do império português no contexto do estabelecimento da Corte na América. Partindo, muitas vezes, de um denominador comum, e sem deixar de expressar a herança das reflexões da ilustração portuguesa, os seus autores acabavam por defender, muitas vezes, posições distintas, e mesmo antagônicas, acerca da política econômica mais adequada para a preservação do Império português.

A produção da Impressão Régia do Rio de Janeiro, atuando sob o controle da Secretaria de Estado dos Negócios Estrangeiros e da Guerra e sob um rígido aparato censório, a frente do qual se destacava a figura de José da Silva Lisboa, que atuava concomitantemente nas duas instâncias de censura pelas quais deveria passar uma publicação antes de ter a sua circulação liberada, se esforçou em enunciar um discurso homogêneo sobre Economia Política, baseado na defesa do livre comércio e dos tratados comerciais com a Inglaterra, cujo principal objetivo era justificar a nova política econômica praticada por D. João. Ao mesmo tempo, procurava não deixar transparecer na nova Corte aquelas perspectivas antagônicas, não dando repercussão na América portuguesa às ideias divergentes e exercendo, o seu poder de narrar e de impedir a formação de narrativas.

Porém, mesmo sendo o próprio Silva Lisboa um dos censores régios, ainda assim era possível ler na corte ideias contrárias às suas, graças ao caráter seletivo da censura no Império Português. Pois, se por um lado, a circulação do Correio Brasiliense de Hipólito da Costa era proibida, ao menos formalmente; por outro, 
algumas obras de José Acúrsio das Neves conseguiam passar pelo controle da entrada de livros exercida pelos Censores do Desembargo do Paço e circular no Rio de Janeiro. Além disso, havia ainda a publicação em $O$ Patriota de Memórias como as de Alexandre de Gusmão e Duarte Ribeiro de Macedo, que expressavam ideias radicalmente contrárias à de Silva Lisboa. Longe de ser um crítico da monarquia portuguesa tal como Hipólito da Costa, Manuel Ferreira de Araújo Guimarães, redator daquele periódico, era homem afinado com o projeto imperial de D. Rodrigo de Sousa Coutinho, tendo sido também redator da Gazeta do Rio de Janeiro durante a maior parte do reinado de D. João no Rio de Janeiro (entre 1812 e 1821).

Assim sendo, as vozes discordantes não se justificavam apenas pela posição geográfica dos seus autores dentro do Império. Se, por um lado, as divergências entre Silva Lisboa e Acúrsio das Neves acerca da franqueza de comércio e indústria, apontam para uma divergência de interesses entre os comerciantes e proprietários de terra da América portuguesa e a burguesia mercantil e industrial do Reino, após a transferência da Corte para o Rio de Janeiro; e as críticas de Hipólito da Costa se baseiam nos malefícios para o Império português que ele enxerga nos tratados comerciais com a Inglaterra; por outro lado, a publicação em O Patriota de memórias que retomavam antigas contribuições para o debate sobre o desenvolvimento ou não de manufaturas, indicava que aquelas tensões existiam também dentro da própria corte do Rio de Janeiro. A existência dessas tensões não era novidade para D. João ou D. Rodrigo de Sousa Coutinho, que conviviam com elas desde o fim do século anterior. Elas acompanharão a corte na sua transferência para a América, ficando ainda mais explícitas após o final da guerra na Europa e a elevação do Brasil a Reino Unido. Atenuar essas tensões, propagandeando um futuro de prosperidade para a monarquia portuguesa re-criada nos trópicos era a função que a Impressão Régia do Rio de Janeiro desempenhava naquele projeto político. 


\section{A Memória de um Poderoso Império}

Entre 1816 e 1817, paralelamente aos seus estudos de Economia Política, José da Silva Lisboa se dedicou a escrever uma crônica do reinado de D. João desde o início da sua regência: a Memória dos benefícios políticos do Governo de el-rey Nosso Senhor D. João VI. ${ }^{1}$ Atendia, dessa forma, a uma encomenda da própria Coroa, que pretendia que tal crônica fosse publicada por ocasião da Aclamação de D. João como rei do Reino Unido de Portugal, Brasil e Algarves, que iria ocorrer em fevereiro de 1818 no Rio de Janeiro. A primeira cerimônia de Aclamação de um monarca europeu ocorrida na América veio coroar o processo de (re)criação da monarquia portuguesa nos trópicos, iniciado com a transferência da corte para o Rio de Janeiro em 1807, e pretendia pôr fim à sensação de transitoriedade e insegurança intrínsecas à regência. A importância daquele acontecimento, que Silva Lisboa denomina equivocadamente de coroação, está expressa na Satisfação ao Público que escreve a modo de prefácio, onde procura justificar a elaboração da sua Memória:

O dia da coroação de El-Rey Nosso Senhor D. João VI nesta primeira corte do Novo Mundo, fixa tão grande época nos anais da América, que deve ser aclamado, não só em voz transitória, mas também em alguma Memória, que indique os principais benefícios políticos que fez no Estado até a sua Faustíssima Aclamação em 6 de Fevereiro do corrente ano de $1818 .^{2}$

Pelas circunstâncias mesmas em que foi escrita, um caráter laudatório

\footnotetext{
${ }^{1}$ Regente de fato desde 1792, quando foi constatada a incapacidade de governar da Rainha D. Maria I devido ao seu estado de saúde, D. João foi formalmente declarado Príncipe Regente por decreto de 15 de julho de 1799 .

${ }^{2}$ LISBOA, J. da S. Memória dos benefícios politicos do governo d'el Rei D. João VI, p. III. Como explica Jacqueline Hermann, no verbete Aclamação do Dicionário do Brasil Joanino, os reis portugueses não eram coroados nem sagrados como os reis franceses e ingleses. Eram alevantados ou aclamados, participando a coroa como um símbolo do ritual, mas não adornando a cabeça dos monarcas. A solenidade de Aclamação tinha a função de reafirmar o pacto social indissolúvel entre a cabeça do Reino, o próprio Rei, e o seu corpo, ressaltando o caráter místico e sagrado dessa união. No entanto, embora utilizasse o título de rei desde a morte da rainha sua mãe, ocorrida em 20 de março de 1816, D. João esperou quase dois anos para receber o juramento legal, eclesiástico e popular pela sucessão ao trono. Segundo Hermann, o adiamento da celebração parecia indicar "a frágil coesão desse corpo, e simbolicamente tinha grande significado, sobretudo em contexto de franco questionamento dos modelos de monarquia absolutista como era a portuguesa". NEVES, L. M. B. P das e VAINFAS, R. Dicionário do Brasil Joanino - 1808-1821, p. 27 a 31. Porém, ao contrário do que aconteceu no Rio de Janeiro, o pacto entre soberano e súditos celebrado na América repercutiu negativamente entre os vassalos europeus, que desde o fim da guerra contra Napoleão Bonaparte na Europa apelavam insistentemente pela volta do monarca para Portugal.
} 
perpassa toda a obra de Silva Lisboa, que, por isso, se caracteriza como muito mais do que um singelo "compendio das egrégias ações reais", ao contrário do que afirma o autor. ${ }^{3}$ Antonio Cândido classifica as Memórias dos Benefícios Políticos como o exemplo mais bem acabado daquilo que ele denominou de ciclo literário de preito ao rei. Segundo seu julgamento, nada elogioso, da obra de Silva Lisboa, ela não passaria de uma coleção de "desvairadas lisonjas em quase duzentas páginas de prosa túrgida, onde o abuso do grifo e da maiúscula procura, ansiadamente, superar os mais descabelados adjetivos". ${ }^{4}$ Mas essa característica não diminui o interesse da Memória dos Benefícios Políticos que, como afirmou E. Vilhena de Moraes no Prefácio que escreve à reedição da obra de Silva Lisboa feita em 1940 pelo Arquivo Nacional, encerra no seu bojo, “preciosíssimo cabedal de idéias". 5 A começar pela definição do objeto do livro fornecida pelo próprio Silva Lisboa, que define os benefícios políticos como exemplos de espírito superior e iluminada política:

São os atos que manifestam a constante solicitude de manter ilesa a Religião; segura a Ordem Civil; respeitada a Dignidade da Coroa; firme a Independência Nacional; imóvel a Integridade do Império; sólidos os sistemas do bem público; progressivos os Melhoramentos da Sociedade. ${ }^{6}$

Os doze benefícios políticos do governo de D. João, desde o início da sua regência até o momento da sua Aclamação, elencados por Silva Lisboa seriam: I. Legislação Favorável; II. Interdito da França Revolucionária; III. Sistema Defensivo de Portugal; IV. Expedição da Corte ao Brasil; V. Supressão Provisória do Sistema Colonial; VI. Estabelecimento da Corte no Rio de Janeiro; VII. Excitamento do Valor Nacional; VIII. Estabelecimento do Banco do Brasil; IX. Definitiva Franqueza do Comércio e Indústria; X. Declaração do Reino Unido; XI. Promoção das Ciências e Artes e XII. Liberdade Diplomática nos Negócios Estrangeiros.

A abordagem de muitos desses benefícios serve de pretexto para Silva Lisboa reafirmar os princípios do seu pensamento econômico: o elogio ao livre comércio como vetor civilizacional regulado pela mão invisível do mercado e a

\footnotetext{
${ }^{3}$ LISBOA, op. cit., p. 4.

${ }^{4}$ CÂNDIDO, A. Formação da Literatura Brasileira: momentos decisivos, p. 234/235.

${ }^{5}$ MORAES, E. V. de. Prefácio. In: LISBOA, op. cit., p. VI.

${ }^{6}$ LISBOA, op. cit., p. 7/8.
} 
condenação dos privilégios exclusivos do antigo sistema colonial. Por exemplo, o objetivo do capítulo onde analisa o quinto benefício, Supressão Provisória do Sistema Colonial, parece ser tecer um elogio à Carta Régia de Abertura dos Portos, que marcaria "uma grande era nos anais da Civilização":"7

\begin{abstract}
Abrindo os portos sem reserva de artigos comerciais estrangeiros, estabeleceu a correspondência direta das Nações, economizando tempo, trabalho, dispêndio e riscos em derrotas falsas, circuitos forçados, rumos avessos, tratados clandestinos, de que era composto o sistema colonial, em pura perda da Humanidade, inconsiderável vantagem da metrópole e triste desanimação das colônias. Assim, todas as classes de habitantes do Brasil se habilitaram a ver e desfrutar os bens da Natureza e Arte de todos os Estados, nos seus diferentes graus de Civilização, afim de exuberante suprimento do povo e perene estímulo da geral indústria. ${ }^{8}$
\end{abstract}

Tal medida se reveste, no discurso de Silva Lisboa, de um caráter de ousadia e, até mesmo, iluminação divina:

Nesta espontânea resolução (...) da Abertura dos Portos do Brasil a todas as Nações pacíficas, e admissão provisória de todos os gêneros, fazendas e mercadorias, exceto dos de notório Real Estanco, o espírito honrador e benéfico do Príncipe Regente pareceu impelido de súbita luz e raio santo, que descende do Pai das luzes, autor de toda a dadiva optima. ${ }^{9}$

Mas o tema que parece dominar a Memória, ressurgindo na abordagem de mais de um dos benefícios elencados é, antes, o processo de transferência da Corte portuguesa para a América do que a decretação do livre comércio, sua principal consequencia. A transferência é tema de dois benefícios políticos (IV. Expedição da Corte ao Brasil e VI. Estabelecimento da Corte no Rio de Janeiro), que correspondem aos dois maiores capítulos do livro, sendo ainda citado em vários outros. Aparecendo, dessa forma, como o principal benefício político do reinado de D. João.

Os autores de memórias históricas como a de Silva Lisboa as apresentavam como despretensiosas compilações de fatos, registradas com a intenção de preservar sua memória para as gerações vindouras, que não tiveram a oportunidade de presenciá-los, ou para que autores pósteros, protegidos pelo distanciamento, as utilizassem para a escrita de uma História. Como faz o padre Luís Gonçalves dos Santos, autor da mais conhecida crônica do reinado de D.

\footnotetext{
${ }^{7}$ Ibid., p. 66.

${ }^{8}$ Ibid., p. 70.

${ }^{9}$ Ibid., p. 67.
} 
João no Rio de Janeiro, ao lado da Memória dos Benefícios Políticos de Silva Lisboa, as Memórias para servir à história do Reino do Brasil: "Conheço que para os presentes tudo isto é escusado e de nenhum merecimento; mas eu escrevo também para os vindouros. A memória das coisas acaba em poucas gerações e os escritos duram por muitos séculos". ${ }^{10}$ Porém, ao escrevê-las eles não estavam apenas registrando os acontecimentos, mas, mais do que isso, eles estavam construindo a sua memória. Ao narrar os acontecimentos os cronistas os reinterpretavam, fixando uma versão canônica sobre como aqueles fatos deveriam ser entendidos pelos seus contemporâneos e como deveriam ser lembrados pelas gerações posteriores. Nesse ponto, a memória se transformava no próprio passado.

A memória é uma representação seletiva do passado, feita a partir do momento presente, e cujo atributo mais imediato é ser elemento constituinte do sentimento de identidade, tanto individual como coletiva. Segundo análise de Fernando Catroga, enquanto trabalho de seleção, a memória se constitui em uma atividade de re-presentificação, ou seja, de tornar novamente presentes os acontecimentos passados, atribuindo-lhes novos sentidos relacionados às necessidades do presente. Dessa forma, toda memória está relacionada a um projeto, ganhando sentido apenas quando se leva em conta o papel dessas três dimensões temporais na sua construção. Nas palavras do autor, a memória é uma "re-presentificação doadora de futuros ao passado": 11

Todos estes condicionamentos ditam que a memória seja sempre seletiva, pelo que ela não pode ser encarada como um armazém inerte, onde, por ocasional e arbitrária acumulação, se recolhem os acontecimentos vividos por cada indivíduo, tal como acontece com as coisas amontoadas no sótão da casa dos avós. Bem pelo contrário, ela é retenção afetiva e "quente" dos "traços" inscritos na tensão tridimensional do tempo que permanentemente a tece. ${ }^{12}$

\footnotetext{
${ }^{10}$ SANTOS, L. G. dos. Memórias para servir à história do Reino do Brasil, tomo 1, p. 59. As suas Memórias têm também a nítida intenção de louvar D. João como artífice do Reino do Brasil, que certamente ele não imaginava tão efêmero. A respeito da obra de Gonçalves dos Santos e da construção da memória do reinado de D. João VI, ver BARRA, S. Entre a Corte e a Cidade: $O$ Rio de Janeiro no Tempo do Rei (1808-1821), p. 33 a 95.

${ }^{11}$ CATROGA, F. Os passos do homem como restolho do tempo: memória e o fim da história, $\mathrm{p}$. 18.

${ }^{12}$ Ibid., p. 16. Ao mesmo tempo, e pelo mesmo motivo, guarda uma relação necessária com o seu contrário, o esquecimento, constituindo-se o recordado como "a ponta do iceberg do esquecido" (Ibid., p. 20). O historiador da ciência Paolo Rossi já havia chamado a atenção para o profundo entrelaçamento existente entre memória e esquecimento. Segundo argumentação desse autor, ao mesmo tempo em que nosso interesse cada vez maior pela memória está ligado ao nosso medo do esquecimento; o esquecimento, muitas vezes voluntário (uma contradição apenas em termos) é, às vezes, necessário para os Estados, para as coletividades e para os indivíduos. Nesses casos, o
} 
Segundo a argumentação de Catroga, "se a memória é instância construtora e cimentadora de identidades, a sua expressão coletiva também atua como instrumento e objeto de poder(es) mediante a seleção do que se recorda e do que, consciente ou inconscientemente, se silencia". ${ }^{13}$ Catroga utiliza o conceito de metamemória para definir essa memória coletiva ou histórica ativamente produzida e reproduzida por esse trabalho de seleção. Segundo seu raciocínio, a metamemória se diferencia da memória social e se opõe às memórias individuais, entendidas como frutos de recordação espontânea de coletividades ou indivíduos respectivamente:

As memórias coletivas, com as suas pluralidades muitas vezes conflituosas e irredutíveis, comparticipam da memória social, substrato adquirido e matricial que, mesmo quando aquelas se extinguem, permite acreditar na continuidade do tempo social e possibilitar a gênese de novas memórias coletivas e históricas. ${ }^{14}$

O sociólogo austríaco Michael Pollack, por sua vez, ressalta que a importância da construção dessa memória coletiva pelo Estado, ou sob seu incentivo, reside no fato de que a referência ao passado serve para manter a coesão dos grupos e das instituições que compõem uma sociedade, para definir seu lugar respectivo, sua complementaridade, mas também as oposições irredutíveis: "Manter a coesão interna e defender as fronteiras daquilo que um grupo tem em comum, em que se inclui o território (no caso dos Estados), eis as duas funções essenciais da memória comum". ${ }^{15}$ Porém, como chamou a atenção Pollack, não há apenas uma memória para cada período histórico. Via de regra, diferentes memórias entram em disputa pela hegemonia da forma como datas e acontecimentos vão ser gravados na memória de um povo. ${ }^{16}$ Por isso, a memória

esquecimento do passado é seguido pela construção de outro passado mais conveniente. Haveria, dessa forma, a necessidade não apenas de aprender a lembrar, mas também de aprender a esquecer, para erradicar do nosso futuro a opressão da recordação. ROSSI, P. Ricordare e Dimenticare, p. 13 a 34.

${ }^{13}$ CATROGA, op. cit., p. 47.

${ }^{14}$ Ibid., p. 15.

${ }^{15}$ POLLACK, M. Memória, esquecimento, silêncio, p. 9.

16 Pollack se refere especificamente ao caráter destruidor, uniformizador e opressor que pode assumir a memória coletiva nacional, considerada por ele a mais completa e organizada forma de memória coletiva. Em momentos de crise, memórias subterrâneas costumam aflorar, invadindo o espaço público com reivindicações múltiplas e imprevisíveis: "Embora na maioria das vezes esteja ligada a fenômenos de dominação, a clivagem entre memória oficial e dominante e memórias subterrâneas, assim como a significação do silêncio sobre o passado, não remete forçosamente à 
coletiva é construída por aquilo que ele denomina de um trabalho de enquadramento da memória, realizado por atores sociais diretamente ligados às instituições construtoras dessa metamemória: "guiado pela preocupação não apenas de manter as fronteiras sociais, mas também de modificá-las, esse trabalho reinterpreta incessantemente o passado em função dos combates do presente e do futuro". ${ }^{17}$ Papel certamente desempenhado por Gonçalves dos Santos e Silva Lisboa ao escreverem suas memórias do reinado de D. João. ${ }^{18}$

O que se pretende nesse capítulo é investigar de que forma as representificações dos principais acontecimentos políticos ocorridos no Império Português na conjuntura da guerra contra os exércitos de Napoleão, realizadas por aquilo que aqui denominamos de memorialismo histórico ou político (constituído por Memórias, panfletos e mesmo notícias sobre a guerra insertas na Gazeta do Rio de Janeiro) contribuíam para esse trabalho de enquadramento da memória e de construção da metamemória do reinado de D. João no Rio de Janeiro. ${ }^{19}$ E, ao fazê-lo, assumiam um importante papel político na legitimação e justificativa de um projeto político posto em prática a partir da transferência da sede da monarquia para o Rio de Janeiro: o projeto de criação de um novo império português na América. Ao mesmo tempo, re-presentificações diferentes dos mesmos fatos políticos, escritas naquele mesmo momento, e que vieram à luz no Rio de Janeiro (apesar do trabalho da censura a que estava submetida a Impressão Régia), em Portugal, ou até mesmo em outras partes da Europa, parecem revelar as tensões surgidas no interior do Império português na efetivação daquele projeto

oposição entre Estado dominador e sociedade civil. Encontramos com mais freqüência esse problema nas relações entre grupos minoritários e sociedade englobante”. (Ibid., p. 7).

${ }^{17}$ Ibid., p. 11.

${ }^{18}$ Durante o Primeiro Reinado, Silva Lisboa, já então Visconde de Cairu, iria desempenhar o mesmo papel ao ser incumbido por D. Pedro I de escrever uma memória da independência e da aclamação do primeiro imperador do Brasil. A História dos Principais Sucessos Políticos do Império do Brasil foi composta em quatro Tomos e editada entre 1827 e 1830 pela Tipografia Imperial, sucessora da Impressão Régia. Cecília Helena de Salles Oliveira explora essa fonte, chamando a atenção para a sua intenção de perpetuar uma memória cuidadosamente cultivada sobre a fundação do Império do Brasil: "Produzida em grande parte para preservar do desgaste político a figura do imperador, em momento marcado pela perda da popularidade em função da Guerra da Cisplatina e de embates entre ministros e Câmara dos Deputados". OLIVEIRA, C. H. de S. Repercussões da revolução: delineamento do império do Brasil, 1808/1831, p. 23.

${ }^{19}$ Memorialismo político e memorialismo científico recebiam ambos, no início do século XIX, o nome genérico de Memórias. A definição de memória englobava então os dois sentidos, podendo significar tanto "escritos de narrações políticas", quanto "memórias de fatos literários ou científicos", segundo a descrição encontrada na segunda edição do dicionário de Antonio de Morais e Silva, publicada em 1813. SILVA, A. M. Dicionário da Língua Portuguesa, p. 286. 
e apontam para projetos políticos alternativos para o Império português.

\section{1.}

\section{A Transferência e suas re-presentificações}

Enquanto membro da Junta do Comércio e conselheiro do Príncipe Regente, o naturalista italiano Domenico Vandelli escrevia não apenas sobre História Natural, mas também sobre assuntos financeiros e econômicos e sobre aspectos diplomáticos e militares, apresentando uma percepção global do império. Em agosto de 1799, Vandelli escreveu uma carta onde apontava a existência de uma oposição à regência de D. João que podia ser observada dentro da própria Corte. ${ }^{20}$ Segundo ele, seria possível identificar a existência de dois partidos no interior do governo de D. João. De um lado, encontrariam-se os membros da grande nobreza ou puridade, nas palavras de Vandelli; e, do outro lado, aqueles que eram designados, impropriamente segundo ele, de pombalinos. ${ }^{21}$ Demonstrando uma clara tomada de posição, o naturalista italiano caracterizava da seguinte maneira os dois partidos:

O partido puritano tendia para a oligarquia; a monarquia lhe era indiferente e lhe convinha a desordem para governar e para enriquecer (...). O segundo partido, pelo contrário, amava o soberano, desejava o respeito pelo trono, queria que houvesse justiça, que não tivesse lugar dilapidação do patrimônio público, (...) e que não houvesse despotismo ministerial. ${ }^{22}$

Com essa carta, Vandelli procurava denunciar o andamento de uma campanha de descrédito da regência por parte da grande nobreza, baseada na divulgação da idéia da incapacidade do Príncipe Regente. Segundo ele, falava-se em afastar D. João do governo. A formalização da regência um mês antes gerou oposições, principalmente por parte da primeira nobreza titular do Reino,

\footnotetext{
${ }^{20} \mathrm{O}$ documento é citado por Jorge Pedreira e Fernando Dores Costa, que não deixam claro se a carta de Vandelli foi entregue ao Príncipe Regente ou a algum ministro da administração do Império.

${ }^{21}$ Explicam Pedreira e Costa que o termo partidos, no final do século XVIII, referia-se a agrupamentos de pequeníssima dimensão, informais e instáveis, constituídos por homens de corte unidos por amizades, em função da distribuição de lugares no governo. A designação de partido era negativa, usava-se contra os adversários e ninguém a reconhecia em relação a si próprio e ao seu grupo (PEDREIRA, J. e COSTA, F. D. D. João VI: um príncipe entre dois continentes, p. 82). A expressão espírito de partido é facilmente encontrada nos documentos da época, e era utilizada para denunciar a defesa de interesses particulares, em oposição à preocupação com o bem comum. ${ }^{22}$ Ibid., p. 84.
} 
insatisfeita com a influência de membros da chamada segunda nobreza (ou nobreza de província) no Conselho de Estado de D. João. Essa oposição irá marcar a regência de D. João, expressando a sua fragilidade. Como explicam Jorge Pedreira e Fernando Costa: "A situação de regência foi invariavelmente uma situação de fragilidade da monarquia. A interinidade suscitava maior dificuldade em dirigir os conflitos e as rivalidades. A fonte de autoridade era imperfeita" ${ }^{23}$

Os dois partidos representariam, ao mesmo tempo, duas orientações distintas com relação à complicada conjuntura diplomática em que se encontrava a monarquia portuguesa. Segundo Vandelli, a grande nobreza seria favorável à conservação de uma negociação secreta com a França, enquanto os pombalinos se opunham à paz com a França, defendendo um alinhamento com a Inglaterra. Vandelli não estava errado no seu diagnóstico sobre a divisão. Tal divisão entre puritanos e pombalinos no interior da Corte, porém, ao contrário do que escreve Vandelli, não correspondia inteiramente a uma divisão entre francófilos e anglófilos respectivamente. Exemplo disso é o fato de personagens da primeira nobreza, como D. João de Almeida de Melo e Castro (1756-1814), $5^{\circ}$ Conde das Galveias, ou D. Tomás Xavier de Lima Nogueira Vasconcelos Teles da Silva (1727-1800), $1^{\text {o }}$ marquês de Ponte de Lima, defenderem a aliança com a Inglaterra, como ressaltam Jorge Pedreira e Fernando Costa:
A oposição no nível diplomático organizava-se na realidade entre a consideração de que a existência do reino dependia por completo da proteção inglesa, pelo que não deveria haver nenhum afastamento, ainda que menor, da orientação de Londres, e a consideração de que essa sobrevivência dependia de uma situação de estrita neutralidade, sem um alinhamento definido, jogando sempre e sistematicamente na ambigüidade, no caso de os ingleses não se mostrarem capazes de manter a proteção militar do reino. Isso implicava criar distância da Inglaterra e estabelecer alguma aproximação com a França. Sobretudo, o que parecia motivar o segundo "partido" era evitar a guerra a todo custo. ${ }^{24}$
O ano de 1801 marca o momento de auge da influência do partido inglês na Corte portuguesa, com a nomeação de D. Rodrigo de Sousa Coutinho para a Presidência do Erário Régio, de D. João de Almeida para Ministro dos Negócios

\footnotetext{
${ }^{23}$ Ibid., p. 79.

${ }^{24}$ Ibid., p. 88/89. Lúcia Bastos, por sua vez, ressalta que a divisão entre anglófilos e francófilos também não correspondia a divergências nascidas de uma postura absolutista e outra liberal, nem de qualquer princípio ideológico mais claro, "o que estava em questão para Portugal era a conjuntura internacional e a análise dos interesses políticos e econômicos da aliança com a Inglaterra diante da avaliação dos demais fatores concretos envolvidos". (NEVES, L. M. B. P. das. Napoleão Bonaparte: Imaginário e Política em Portugal c. 1808-1810, p. 76).
} 
Estrangeiros e da Guerra e de Luís Pinto de Sousa para o Ministério dos Negócios do Reino. ${ }^{25}$ Auge que, no entanto, durou pouco, pois já em 1803 D. Rodrigo entregava a sua carta de demissão ao Príncipe Regente, e D. João de Almeida era afastado do governo por pressão do embaixador francês, o General Jean Lannes (1769-1809). Como explica Ana Rosa Cloclet da Silva, em seu pedido de demissão dirigido ao Príncipe Regente em 15 de novembro daquele ano, D. Rodrigo referia-se "à fraca aceitação que suas propostas de reforma das finanças públicas encontravam naquele momento." ${ }^{26}$ Discute-se se haveria ou não uma correspondência entre o pedido de demissão de Sousa Coutinho e o seu afastamento efetivo da Presidência do Real Erário; ou se, por outro lado, ela estaria mais relacionada às intrigas palacianas da corte portuguesa e à pressão do embaixador francês, que reforçaram as oposições ao Ministro, levando ao seu afastamento da vida pública entre 1803 e $1807 .^{27}$

Em 1804, Antonio de Araújo de Azevedo assumiria a pasta dos Negócios Estrangeiros e da Guerra, marcando a virada na política externa portuguesa em favor dos partidários de um acordo com a França. A pressão francesa e a ameaça de invasão confirmavam a posição do partido francês, que acreditava que a política diplomática dos partidários da Inglaterra não era eficaz nem possível diante daquela conjuntura. Segundo síntese de Jorge Pedreira e Fernando Costa:

\begin{abstract}
Nos anos de 1803 a 1805, a regência sofreu a oposição de elementos da primeira nobreza e o príncipe viu-se forçado, perante a crescente pressão da França como potência hegemônica na escala do continente europeu, a uma modificação da orientação diplomática, expressa na negociação com o governo de Paris de um tratado de neutralidade que incluiu a previsão do pagamento de uma pesada contribuição financeira. ${ }^{28}$
\end{abstract}

A pressão francesa para retirar Portugal da órbita de influência da Inglaterra

\footnotetext{
${ }^{25}$ Apesar da ausência de apoio inglês no episódio que ficou conhecido como Guerra das Laranjas, contra a Espanha, ocorrida naquele ano. Como ressaltam Kirsten Schultz e Lúcia Bastos, o conflito resultou na perda de Olivença e em um tratado que estipulava, entre outras coisas, o fechamento dos portos portugueses aos ingleses. (SCHULTZ, K. Versalhes Tropical: Império, monarquia e corte real portuguesa no Rio de Janeiro, 1808-1821, p. 55; e NEVES, op. cit., p. 80).

${ }^{26}$ SILVA, A. R. C., op. cit., p. 182.

${ }^{27} \mathrm{Na}$ mesma ocasião, Lannes exigiu também o afastamento do intendente de polícia Pina Manique, devido à sua perseguição aos suspeitos de divulgarem os abomináveis princípios franceses em território português. A respeito do período que Lannes passou em Lisboa como embaixador francês, ver PEDREIRA e COSTA, op.cit., p. 118 a 131; NEVES, op. cit., p. 80/81; CARDOSO, J. L. O pensamento econômico em Portugal nos finais do século XVIII 1780-1808, p. 186 a 189.

${ }^{28}$ PEDREIRA e COSTA, op.cit., p. 104.
} 
avançou num crescente até novembro de 1806, quando o governo francês decretou o Bloqueio Continental. Ao mesmo tempo, a Inglaterra pressionava pelo outro lado, na tentativa de impedir qualquer cessão do governo português à França, ameaçando com o bloqueio do porto de Lisboa, o aprisionamento da sua marinha de guerra e, até mesmo, a invasão de portos no Brasil. Tal situação tornava insustentável a política de neutralidade até então praticada pela Coroa portuguesa. Como chamam a atenção Jorge Pedreira e Fernando Costa, a tentativa de preservar a neutralidade a todo custo, evitando tomar partido entre França e Inglaterra, havia conduzido Portugal a uma potencial situação de guerra com as duas potências. ${ }^{29}$ Os esforços diplomáticos foram abandonados de uma vez por todas quando chegou a Lisboa um correio extraordinário enviado pelo ministro português em Londres, Domingos de Sousa Coutinho, que trazia uma cópia da edição de 11 de novembro do Le Moniteur, que continha o texto do Tratado de Fontainebleau, concluído entre Napoleão e Carlos IV, rei da Espanha; ${ }^{30}$ e, principalmente, quando foram recebidas notícias de que e as tropas francesas sob o comando do General Jean-Andoche Junot (1771-1813) tinham cruzado a fronteira hispano-lusitana, por volta dos dias 22 ou 24 de novembro de $1807 .{ }^{31}$

D. Rodrigo de Sousa Coutinho foi um dos primeiros a diagnosticar a falência do estatuto de neutralidade até então mantido por Portugal frente ao conflito europeu. Em ofício datado de 14 de outubro de 1795, antes mesmo de deixar o seu cargo diplomático em Turim para assumir a pasta da Marinha e Ultramar, D. Rodrigo já afirmava que a idéia de neutralidade em um momento como o que estava passando a monarquia portuguesa era pueril e não poderia existir. $^{32}$ Ele não acreditava na possibilidade de um acordo estável com a França, devido à imposição de fechamento dos portos portugueses a navios ingleses. A saída seria promover a defesa do território português. Mas não apenas a defesa do

\footnotetext{
${ }^{29}$ PEDREIRA e COSTA, op.cit., p. 178.

${ }^{30}$ Em linhas gerais, por esse tratado os soberanos de França e Espanha decidiam a repartição do território Português, após a sua conquista, em três partes: as províncias de Entre-Douro e Minho seriam dadas ao Rei da Etrúria com o título de Lusitânia Setentrional; as províncias do Além-Tejo e Algarves ficariam de posse da Coroa Espanhola; e as províncias da Beira, Trás-os-Montes e Extremadura, a maior parte do território português, caberiam ao monarca Francês. Integra do texto do Tratado em LIGHT, K. A viagem marítima da Família Real, p. 240.

${ }^{31}$ Importante deixar claro que não é nossa intenção aqui esgotar o tema da conjuntura diplomática européia que precedeu à primeira invasão francesa de Portugal e à transferência da Corte para a América. Para maiores detalhes sobre o assunto, remeto à bibliografia citada neste capítulo.

${ }^{32}$ Documento citado por Ana Rosa Cloclet da Silva (SILVA, A. C. R. da. op. cit., p. 177).
} 
Reino. Devendo-se, inclusive, relegar a metrópole a segundo plano, em caso extremo. Ao ser consultado, em 1803, sobre a situação européia, a opinião de Sousa Coutinho sobre a importância do Brasil dentro do Império Português embasou sua recomendação para que o Príncipe Regente transferisse para a América a sede da monarquia. Na sua Memória sobre a mudança da sede da monarquia, D. Rodrigo declarou a D. João que "Portugal não é a melhor parte da monarquia". Em sua opinião, diante do quadro de incertezas que rondava o reino na Europa, sempre restaria ao soberano a alternativa de criar um poderoso império no Brasil, de onde poderia tornar a reconquistar o que poderia ter perdido na Europa. O que D. Rodrigo vislumbrava naquele momento era o próprio risco da perda da soberania da Monarquia Absolutista sobre os seus territórios e, para preservá-la, recomendava a já mencionada radical ruptura da política de neutralidade, tendo em vista a defesa do Reino e do Brasil, que, em último caso, serviria de esteio ao Trono. Como explica Nívia Pombo Cirne dos Santos, "Era a salvaguarda de um império que estava em questão para D. Rodrigo de Sousa Coutinho". 33

A proposta de transferência da Corte para os domínios portugueses da América não era nova. Escrevendo nos anos 1730, o diplomata e estrangeirado português D. Luiz da Cunha (1662-1749), embaixador em Paris e delegado nas negociações do Tratado de Utrecht (1713-1715), chamava a atenção para a preeminência do Estado do Brasil sobre todas as outras partes constituintes do Império português, incluindo a própria metrópole. Ele observou que enquanto o Brasil era virtualmente um continente, Portugal não passava de uma orelha de terra: “A solução desse problema, propôs então Cunha, era mudar a corte para o Brasil, onde João V poderia tomar o título de 'Emperador do Ocidente'.”34 O cerne do pensamento de Cunha baseava-se na idéia de que "não pode El-Rei manter Portugal sem o Brasil, enquanto que para manter o Brasil não carece de Portugal". ${ }^{35}$ A criação de um novo império no Novo Mundo aparece na proposta de D. Luiz da Cunha não apenas como forma de fugir aos imperialismos britânico e espanhol, mas como forma de desenvolver o império português a partir de uma

\footnotetext{
${ }^{33}$ SANTOS, N. P. C. dos. Dom Rodrigo de Sousa Coutinho: Pensamento e ação políticoadministrativa no Império português (1778-1812), p. 65.

${ }^{34}$ SCHULTZ, op. cit., p. 42.

${ }^{35}$ NORTON, L. A Corte de Portugal no Brasil: Notas, documentos diplomáticos e cartas da imperatriz Leopoldina, p. 15.
} 
melhor exploração do seu potencial econômico. Segundo o pensamento do estadista português, não havia nada a produzir em Portugal que não pudesse ser produzido no Brasil. Ao mesmo tempo, não havia aplicação nem indústria suficientes para utilizar em Portugal os recursos do Brasil. Mudar o centro político do império para o Brasil serviria como ponto de partida para uma administração mais racional e uma exploração mais completa dos recursos da colônia. As perdas territoriais na Europa também poderiam ser compensadas pela expansão territorial no Novo Mundo. Como ressalta Kirsten Schultz: "Desse modo, o potencial americano tanto respondia quanto deslocava as vulnerabilidades européias", 36

Também D. Pedro de Almeida Portugal (1754-1813), $3^{\circ}$ Marquês de Alorna, em carta ao Príncipe Regente de 30 de maio de 1801, após a derrota de Portugal na Guerra das Laranjas, refletindo sobre a debilidade e desorganização dos recursos militares portugueses, que impossibilitavam a defesa do Reino frente a uma possível invasão franco-espanhola, sugere a transferência da Corte para a colônia. Ou que, pelo menos, D. João anunciasse a intenção de retirar-se para o Brasil pois, segundo seu raciocínio, essa ameaça já seria suficiente para fazer recuar os franceses:

\begin{abstract}
V.A.R. tem um grande império no Brasil, e o mesmo inimigo que ataca agora com tanta vantagem, talvez que trema e mude de projeto se V.A.R. o ameaçar de que se dispõe a ir ser imperador naquele vasto território adonde [sic] pode facilmente conquistar as colônias espanholas e aterrar em pouco tempo as de todas as potências da Europa. Portanto, é preciso que V.A.R. mande arrumar com toda a pressa todos os seus navios de guerra e todos os de transporte que se acharem na praça de Lisboa, que meta neles a Princesa e seus filhos, os seus tesouros, e que ponha tudo isto pronto a partir sobre a barra de Lisboa. ${ }^{37}$
\end{abstract}

Como ressaltam Jorge Pedreira e Fernando Costa, tanto nos projetos de D. Luis da Cunha, quanto no de Alorna, o Brasil era visto não como um local de refúgio e de recuo, e sim de redefinição das relações de força; e a transferência podia ser entendida como "um projeto de continuidade e mesmo de engrandecimento dos domínios da casa de Bragança, que seguiria reinando mas fora da Europa, e não de mera fuga dos inimigos". ${ }^{38}$ Projeto político expresso no

\footnotetext{
${ }^{36}$ SCHULTZ, op. cit., p. 47.

${ }^{37}$ Arquivo Nacional do Rio de Janeiro. Coleção Negócios de Portugal. Caixa 712, Pacote 2. Documento 3. Carta do Marquês de Alorna aconselhando D. João a vir para o Brasil. 30 de maio de 1801. Documento citado por Lúcia Bastos (NEVES, op. cit., p. 85/86).

${ }^{38}$ PEDREIRA e COSTA, op. cit., p. 98. Afirma Ana Rosa Cloclet que ante a ameaça de uma invasão que pusesse em risco a pessoa real ou as possessões ultramarinas, os próprios membros do
} 
manifesto publicado a $1^{\circ}$ de maio de 1808 , onde D. João, recém-instalado no Rio de Janeiro, procura expor as justificativas para a transferência da sua Corte para a América e onde também declara guerra à França. ${ }^{39}$ Logo no início desse documento, ao declarar os objetivos da sua publicação, afirma o monarca português, em passagem muito repetida pelos cronistas da época, que não era com injúrias e nem com vãs ameaças que "a Corte de Portugal levantará a sua voz do seio do novo império que vai criar". ${ }^{40}$ Deixando expressa, dessa forma, na decisão de transferir a Corte para o Rio de Janeiro, a intenção de criação de um novo Império Português nos trópicos.

Porém, apesar de sair vitorioso ao final do processo, o projeto de transferência da sede do império português para a América, concebido como manobra brilhante para tirar a Coroa do conflito europeu e forjar um império maior e mais independente, não foi compartilhado pela corte portuguesa como um todo. Segundo Ana Rosa Cloclet, pode-se mesmo dizer que D. Rodrigo representou um caso extremo, ao desacreditar da política de neutralidade. Cumpre recordar que a redação da Memória sobre a mudança da sede da monarquia coincide com o momento do afastamento do governo e da desgraça política de D.

partido francês não descartavam a alternativa da transferência da Corte: "Acreditamos, contudo, que as divergências entre os membros do Conselho de Estado, reunidos desde agosto de 1807, fundavam-se muito mais em interpretações distintas quanto à eficácia do jogo diplomático na resolução pacífica de um iminente conflito, que numa diversidade de objetivos, visto que estes acenavam, invariavelmente, com a necessária preservação da soberania da monarquia nacional, dependente dos dois elementos básicos, em torno dos quais giravam seus discursos e propostas políticas: a América portuguesa e a integridade da pessoa real. Ao fim e ao cabo, todos contavam com a possibilidade de uma estratégica retirada da Corte, ainda que as oportunidades de tempo e meios para efetuá-la fossem diferentemente concebidas" (SILVA, A. C R. da. op. cit., p. 196/197).

${ }^{39}$ Segundo o texto desse documento, a falta de reconhecimento, por parte da França, do direito de Portugal à neutralidade frente ao conflito entre França e Inglaterra (direito fixado inclusive em tratados firmados entre França e Portugal), e a posterior invasão do território português por tropas francesas fez com que o monarca português tomasse a resolução de transferir a sua Corte para os seus domínios americanos: "S.A.R. o Príncipe Regente abraçou então o único partido que poderia convir-lhe, para não se afastar dos princípios que tinha constantemente seguido, para poupar o sangue dos seus povos e para evitar a completa execução das vistas criminosas do governo francês, que não se propunha nada menos que apoderar-se da sua Sua Real Pessoa, para poder depois, ao seu modo e segundo the parecesse, repartir os despojos da Coroa de Portugal e dos seus Estados. (...) A magnânima resolução que S.A.R. abraçou de retirar-se aos seus Estados do Brasil com Sua Augusta Família Real tornou totalmente inúteis os desígnios do governo francês". Manifesto, ou exposição fundada, e justificativa do procedimento da Corte de Portugal a respeito da França, desde o princípio da Revolução até a época da invasão de Portugal; e dos motivos, que a obrigaram a declarar a guerra ao Imperador dos Franceses, pelo fato da invasão, e da subseqüente Declaração de Guerra feita em conseqüência do Relatório do Ministro das Relações Exteriores. COSTA, H. J. da. Correio Braziliense ou Armazém Literário. Setembro de 1808, p. $265 / 266$.

${ }^{40}$ Ibid., p. 256. 
Rodrigo, que voltará a ser admitido nas reuniões do Conselho de Estado somente em agosto de 1807, quando, diante da delicada posição de Portugal frente à nova conjuntura internacional, os estadistas portugueses começaram a reconsiderar a ideia de transferência da Corte.

A sua execução não podia ocorrer sem provocar uma profunda modificação em relação ao que havia sido pensado nos planos do reformismo ilustrado português. A transplantação da Corte para o Estado do Brasil criava uma situação nova, e a construção do novo império português teria que negociar com a própria realidade colonial, levando em conta os interesses da elite proprietária e mercantil colonial, entre os quais a manutenção da escravidão. ${ }^{41}$ Nessa nova situação criada pela transferência, o antigo Reino perdia o papel de nexo da unidade imperial, de centro do império, que mantinha no programa de reformas de D. Rodrigo de Sousa Coutinho, ${ }^{42}$ e colocava em segundo plano os interesses da burguesia mercantil e manufatureira do Reino e dos membros da nobreza que não tinham interesses no Brasil, e também era percebido como algo que servia aos interesses britânicos significando, consequentemente, o rompimento explícito do estatuto de neutralidade. Assim, se a princípio letrados e estadistas portugueses nascidos de um e outro lado do Império compartilhavam das ideias da criação de um poderoso império que integrasse os territórios separados pelo Oceano, a dinâmica da política imperial mesma do reformismo ilustrado propiciava e acelerava a própria crítica ao sistema imperial projetado, revelando a ruptura na comunidade de interesses dos dois lados do Atlântico português. ${ }^{43}$ Dessa forma, assiste-se a uma

\footnotetext{
${ }^{41}$ Em Construtores e Herdeiros, Ilmar Rohloff de Mattos chamou a atenção para a existência da escravidão como uma herança que também se impunha aos construtores do Império do Brasil. (MATTOS, I. R. de. Construtores e Herdeiros: a trama dos interesses na construção da unidade política, p. 25). Herança que, no contexto da construção do novo império português na América, teria que se combinar com a missão civilizatória de disseminação das Luzes no novo Reino e a colocava em evidência.

${ }^{42}$ Como explicou Ilmar Rohloff de Mattos, à unidade espacial e contigüidade territorial do Império do Brasil, forma como era identificada aquela parte constitutiva do Império Português pela sua dimensão territorial e diversidade populacional, não correspondiam uma unidade e uma centralização políticas. O que contribuía para reafirmar o papel do Reino de Portugal como cabeça do Império. Porém, a transferência da capital do Império português para o Rio de Janeiro modificava esse quadro, contribuindo para forjar a imagem do Rio de Janeiro com a cabeça da Monarquia, para a diferenciação da área da Corte e para a difusão da imagem de Brasil: "Ao tornar o Rio de Janeiro o novo centro político e administrativo da Monarquia, estabelecia-se uma dualidade geradora de uma ambigüidade, somente em parte resolvida pela criação do Reino Unido de Portugal, Brasil e Algarves, em 1815.” Ibid., p. 13.

43 João Paulo Garrido Pimenta ressalta a transferência da Corte portuguesa para o Rio de Janeiro como um momento crucial para a consolidação de identidades distintas no interior do Império
} 
inversão da reciprocidade entre as partes componentes do Império. A partir de então, as medidas favoráveis ao Brasil é que também o deveriam ser para Portugal, e não mais o contrário. 1808 se apresenta, dessa forma, como o primeiro momento de reforma da reforma, que colocaria em evidência as tensões existentes no interior do projeto político de criação no novo império português:

O esquema teórico da interdependência e reciprocidade entre as partes do mundo português e sob a preeminência da metrópole, centrada em Portugal, havia sido desmontado com a transferência da Corte para o Rio de Janeiro e pela presença determinante dos interesses ingleses, o que tornava mais difícil relativizar os antagonismos. Esse era o nó que a ilustração reformista luso-brasileira não conseguia desatar. A unidade luso-brasileira, que requeria a aliança e convergência de interesses para se consolidar, perigava ante sinais evidentes da persistência de propósitos que se contrapunham. ${ }^{44}$

Como venho ressaltando, a regência de D. João, desde a sua formalização em 1799, enfrentava a oposição de parte da nobreza portuguesa que apontava para um diferente projeto para o Império português que, no seu extremo, dispensava a presença do Príncipe Regente. A primeira expressão concreta desse projeto veio à tona em fins de 1805 com a assim denominada conspiração dos fidalgos. Uma tentativa de afastamento de D. João, sob o pretexto da degradação do seu estado de saúde, organizada por personagens da primeira nobreza da corte e que contou com a participação de Carlota Joaquina, a quem os conspiradores pretendiam entregar a regência. ${ }^{45}$ Malograda a conspiração, os projetos conspiratórios não se desvaneceram, contudo. A invasão do Reino pelos franceses em 1807 proporcionou a esses opositores uma nova oportunidade de realização do seu

português. Segundo esse autor, nos quatorze anos que antecedem a separação entre Brasil e Portugal, há uma reconfiguração de uma identidade luso-americana anteriormente já existente, então progressivamente reforçada, politizada e cristalizada pela transformação da América em sede da monarquia. A cristalização dessa identidade se expressa por meio de interesses diferenciados: "O que se observa nos anos que imediatamente se seguem à transferência da Corte para o Rio de Janeiro (...) será uma cada vez mais complexa e conflitiva coexistência, no interior da nação portuguesa, entre projetos e alternativas de futuro que, além de se expressarem em identidades coletivas cada vez mais fluidas, terá em tais expressões armas políticas de transformação da realidade. Um panorama permeado de fissuras, cujo agravamento conduzirá a uma situação na qual a pretendida unidade daquele corpo torna-se cada vez mais difícil, e a alternativa da ruptura entre suas partes cada vez mais plausível". PIMENTA, J. P. G. Portugueses, americanos, brasileiros: identidades políticas na crise do Antigo Regime luso-americano, p. 75.

${ }^{44}$ LYRA, M. de L. V. A Utopia do Poderoso Império, p. 148.

45 Jorge Pedreira e Fernando Dores Costa apontam como participantes dessa conspiração o já citado $3^{\circ}$ Marquês de Alorna (D. Pedro de Almeida Portugal), o $5^{\circ}$ conde de Sarzedas (D. Bernardo José Maria Lorena e Silveira, 1756-1818), o $2^{\circ}$ marquês de Ponte de Lima (D. Tomás José Xavier de Lima Vasconcelos Brito Nogueira Teles da Silva, 1799-1822) e o $5^{\circ}$ conde de Sabugal (D. Manuel de Assis Mascarenhas Castelo Branco da Costa Lencastre, 1778-1839). PEDREIRA e COSTA, op. cit., p. 140 a 149. 
projeto de organização do Império Português sem D. João, expressa, então, nos casos de colaboracionismo. Como explica Lúcia Bastos, entrando em Portugal, Junot buscou não só o apoio de alguns segmentos da sociedade portuguesa como também o estabelecimento de uma política de compromissos entre as forças portuguesas e francesas. A nobreza que permaneceu no reino, repleta de ressentimentos contra a Casa de Bragança e avessa a qualquer mudança mais profunda, passou a constituir o principal suporte político do general francês que chegou a receber o título de Duque de Abrantes:

Tanto a nobreza quanto o alto clero, as ordens dominantes da sociedade, mostraram-se, em parte, bastante sensíveis aos apelos de Junot. Se boa parte da nobreza palaciana acompanhou o príncipe regente ao Brasil, aqueles que permaneceram em Portugal, incluindo a maioria dos grandes titulados, tornaram-se o braço direito do general francês. ${ }^{46}$

Como explica a autora, essa adesão era motivada antes por oportunismo do que por filiação ideológica aos princípios liberais franceses. Pelo contrário, ciosos dos seus privilégios, a nobreza lusitana procurava, por meio da adesão aos novos governadores do Reino, manter a ordem e a hierarquia social nessa fase difícil da Regência. Acreditava que chegara o momento propício para retomar o seu antigo papel de conselheira nata do monarca, mesmo que esse rei fosse um estrangeiro. Buscava, dessa forma, compensar a marginalização sofrida desde o período pombalino e que, a despeito da Viradeira, prosseguira no governo mariano. ${ }^{47}$ Porém, ressalta a autora, outro grupo da nobreza aderiu ao governo francês mediante certa opção ideológica:

Foram, na maioria, militares, muito ligados à nobreza, atraídos não só pelo fascínio que la grande Armée exercia, mas também pela figura do herói mitificado Napoleão Bonaparte, invencível em suas conquistas, embora não lhes fosse estranha a idéia de que, apesar do desabono de suas práticas, os novos princípios da Revolução Francesa traziam a oportunidade de implementar algumas instituições novas e modernizar as estruturas de poder, promovendo a tolerância e o progresso cívico, aspectos que eram caros à corrente anglófila da Maçonaria. Dessa forma, engajaram-se nas tropas dos invasores, compondo a chamada Legião Portuguesa. ${ }^{48}$

Interessante notar que três dos principais envolvidos na conspiração de 1805 citados por Jorge Pedreira e Fernando Costa (o Marquês de Alorna, o Marquês de

\footnotetext{
${ }^{46}$ NEVES, op. cit., p. 189.

${ }^{47}$ Ibid., p. 190/191.

${ }^{48}$ Ibid., p. $194 / 195$.
} 
Ponte de Lima e o Conde de Sabugal) viriam a fazer parte da Legião Portuguesa, criada por Junot como forma de aumentar o contingente do exército francês, arregimentando os melhores oficiais e soldados portugueses. O caso de Alorna é o mais conhecido. Uma vez que era o comandante em chefe do exército português em 1807, Alorna foi nomeado comandante geral da Legião Portuguesa. Com um contingente de cerca de 9 mil homens, a Legião ficou aquartelada em Grenoble, combatendo ao lado das tropas francesas na Alemanha, Áustria e Rússia. Em 1810, Alorna participou da $3^{\mathrm{a}}$ invasão francesa de Portugal, ao lado das tropas do General André Massena (1758-1817). Após a expulsão dos franceses, a regência de Portugal privou Alorna de todos os títulos, honras e dignidades, condenando-o também à morte por enforcamento, sendo-lhe antes decepadas as mãos e, depois de decapitado, devendo o corpo ser reduzido a cinzas, que deveriam ser lançadas ao mar, por crime de traição à pátria. Alorna, porém, nunca retornou a Portugal, morrendo na campanha francesa da Rússia em $1813 .{ }^{49}$

No mesmo Decreto em que justificava a sua decisão de transferir-se para o Brasil e nomeava o Conselho de Regência que deveria governar o Reino na sua ausência, D. João mantinha o estatuto de paz e amizade com a França, ordenando aos governadores do Reino que as tropas francesas fossem "bem aquarteladas e assistidas de tudo que lhes for preciso", conservando-se sempre "a boa harmonia que se deve praticar com os exércitos das nações com as quais nos achamos unidos no continente". 50 Após dois meses de ocupação, Junot substituiu o Conselho de Regência nomeado por D. João por um Conselho de Governo composto por três Secretários de Estado franceses e três conselheiros portugueses que eram figuras públicas nacionais. ${ }^{51} \mathrm{Se}$ em um primeiro momento, a

\footnotetext{
${ }^{49}$ Ibid., p. 98 e 195 a 198. A autora analisa ainda o colaboracionismo entre o clero e as camadas populares, ressaltando que, se por um lado, o primeiro grupo não escapou de uma certa colaboração, comportando-se de maneira semelhante à aristocracia; por outro lado, a adesão do segundo grupo aos franceses existiu predominantemente no imaginário das autoridades. Ibid., p. 200 a 229.

${ }^{50}$ Decreto do Príncipe Regente de Portugal pelo qual declara a sua intenção de mudar a corte para o Brasil, e erige uma Regência para governar em sua ausência. COSTA, H. J. da. Correio Braziliense ou Armazém Literário. Junho de 1808, p. 7. Segundo reflexão de Lucia Bastos, o Decreto de 26 de novembro de 1807 foi escrito, provavelmente, por Antonio de Araújo de Azevedo (NEVES, op. cit., p. 92).

${ }^{51}$ Pelo Edital de $1^{\circ}$ de fevereiro de 1808, "Francisco Antonio Herman ficou encarregado da repartição do interior e das finanças, assessorado por Pedro de Melo Breyner e pelo desembargador Azevedo Coutinho; Lhnit, na Secretaria de Estado da Guerra e da Marinha, era apoiado pelo conde de Sampaio e pelo principal Castro, D. Francisco Rafael, regedor para os
} 
colaboração por parte da nobreza portuguesa foi entendida como obediência às ordens do Príncipe-Regente, após a primeira expulsão dos franceses os três membros da Regência que tomaram parte no conselho de governo instituído e presidido por Junot foram impedidos de reassumirem seus postos sob a suspeita de adesão aos interesses franceses. Principalmente por assinarem uma representação solicitando a Napoleão que desse a Portugal um príncipe da sua escolha. $\mathrm{O}$ documento seria entregue ao Imperador francês por ocasião do seu encontro com uma deputação portuguesa enviada a Bayonne, no sudoeste da França, entre março e abril de 1808. A versão oficial desse episódio afirmava que a deputação iria ao encontro de Bonaparte para tentar conseguir algum abatimento na contribuição de 40 milhões de cruzados, decretada por Junot em 1 de fevereiro daquele ano, e pedir a manutenção da Casa de Bragança no trono português, revogando a sua destituição determinada pelo General francês naquele mesmo dia. Mas desde cedo, divulgou-se a ideia de que a sua real finalidade era a de solicitar um monarca francês a Napoleão para governar Portugal. ${ }^{52}$

Terminada a primeira invasão francesa o medo do retorno dos invasores desencadeou uma "caça às bruxas" no Reino, durante os anos de 1809 e 1810, que transformou qualquer indivíduo aberto às novas ideias em partidaristas dos franceses, especialmente aqueles que estavam ligados à maçonaria, uma vez que Jacobino e pedreiro livre tornavam-se sinônimos:

Em meio a esse clima explosivo, em que qualquer rumor se transformava em conspiração com o incentivo da intensa campanha dos governadores do reino, por

assuntos da justiça e do culto; Vienez Blaunc, na terceira Secretaria, ocupou-se da superintendência dos Arquivos". NEVES, op. cit., p. 96.

52 Como explica Lúcia Bastos, a deputação que foi a Bayonne contava com 14 figuras proeminentes, representando distintas instituições do reino (Ibid., p. 98). Uma carta datada de 27 de abril, enviada de Bayonne pela deputação portuguesa e publicada na Gazeta de Lisboa, procurava relatar como havia sido o encontro com Bonaparte e era assinada por: $3^{\circ}$ marquês de Penalva (Fernando Teles da Silva Caminha e Menezes, 1754-1818), $6^{\circ}$ marquês de Marialva (D. Pedro José Joaquim Vito de Meneses Coutinho, 1775-1823), D. Nuno Caetano Álvares Pereira de Melo, $5^{\circ}$ marquês de Valença (D. José Bernardino de Portugal e Castro, 1780-1840), $3^{\circ}$ e $4^{\circ}$ marqueses de Abrantes (D. Pedro de Lencastre da Silveira Castelo Branco Sá e Menezes, 17711828 e D. José Maria da Piedade de Lencastre Silveira Castelo Branco Sá e Menezes, 1784-1827), $5^{\circ}$ conde de Sabugal (o mesmo que havia participado da conspiração de 1805), D. Francisco de Lemos de Faria Pereira Coutinho (bispo de Coimbra e reitor da Universidade, 1735-1822), D. José Maria de Melo (inquisidor geral e bispo do Algarve, 1756-1818), $6^{\circ}$ visconde de Barbacena (Luís Antonio Furtado de Castro do Rio de Mendonça e Faro, 1754-1830), $1^{\circ}$ conde de Mafra (D. Lourenço José Xavier de Lima, 1767-1839), D. José de Almeida (Prior-Mor da ordem militar de S. Bento de Avis), Joaquim Alberto Jorge e Antonio Tomás da Silva Leitão (desembargadores e membros do Senado da Câmara de Lisboa). 
proclamações e editais da polícia, começaram a surgir listas de afrancesados, reais ou imaginários, afixadas nas principais praças da capital. ${ }^{53}$

Em março de 1809, coincidindo com a segunda invasão francesa, teve início uma série de prisões justificadas pela necessidade de assegurar a segurança militar. A maioria dos detidos era ligada à maçonaria. No ano seguinte, no episódio que ficou conhecido como Setembrizada, foi feita mais uma série de prisões. Da lista dos 74 presos detidos ao longo desses dois anos, constava o de Domenico Vandelli, então com 75 anos de idade. A tomada de posição ao lado dos denominados pombalinos e a defesa da regência de D. João no documento de 1799, citado no início desse capítulo, não impediu a sua prisão e a condenação de exílio no Açores, juntamente com os outros detidos. Provavelmente por ser maçom e casado com Feliciana Isabella Bom, de origem francesa, ou mesmo por ter expresso uma posição favorável à aliança com a França em memória escrita em 1796, e significativamente intitulada Se convém atualmente conservar sua antiga aliança. Nesse documento, afirmava Vandelli que a perda do reino era “irremediável e pronta”, caso Portugal se declarasse pela antiga aliança com a Inglaterra. ${ }^{54}$ Mais cauteloso, em outro documento datado de 30 de março de 1800 , Vandelli punha em confronto os argumentos a favor e contra a celebração de um tratado com a França. Argumentava o naturalista italiano que a resolução do problema era muito difícil e que era indispensável analisar bem as razões pró e contra de cada uma das opções, uma vez que a conservação da monarquia dependia dela. ${ }^{55}$ A conturbada conjuntura política por que passava Portugal admitia posturas ambíguas e mudanças radicais de posição em curto espaço de tempo. E também Vandelli, ainda mais do que qualquer súdito português, pelo fato de ser estrangeiro, precisava a todo o momento reafirmar a sua lealdade à monarquia portuguesa, sob o risco de ser considerado um colaboracionista, como

\footnotetext{
${ }^{53}$ Ibid., p. 216. A Impressão Régia do Rio de Janeiro publicou, em 1809, um folheto de autoria anônima intitulada Os Pedreiros-Livres e Os Iluminados, que mais propriamente se deveriam denominar Os Tenebrosos, que cujas seitas se tem formado a pestilencial Irmandade que hoje se chama Jacobinismo, longamente comentada por Hipólito da Costa nas edições do Correio Braziliense de agosto e setembro de 1809 (páginas 141 a 149 e 269 a 276, respectivamente).

${ }^{54}$ Documento citado por Ana Rosa Cloclet da Silva (SILVA, A. R. C. da. op. cit., p. 197/198).

${ }^{55}$ VANDELLI, D. Problema: se atualmente convém aceitar ou rejeitar a Paz. Biblioteca Nacional de Lisboa. Códice 9909, folhas 311-318. Documento consultado por Jorge Pedreira e Fernando Dores Costa (COSTA e PEDREIRA, op.cit., p. 72 a 78).
} 
de fato aconteceu. ${ }^{56}$

A ausência de unanimidade diante da decisão de transferir a Corte para o Rio de Janeiro e a situação de insegurança gerada pela acefalia do Reino, fizeram surgir diversas publicações abordando o tema da transferência e o período de ocupação francesa de Portugal, escritas em forma de memórias e panfletos políticos, não somente no Reino mas por toda a Europa, e publicados também pela Impressão Régia do Rio de Janeiro. ${ }^{57}$ É importante chamar a atenção, antes de qualquer coisa, para as diferentes dinâmicas em que estiveram envolvidas as tipografias existentes nos dois lados do Atlântico português durante essa conjuntura. Apesar de muitos trabalhos publicados em Portugal terem sido, oportunamente publicados também no Rio de Janeiro, as tipografias na velha e na nova capital do Império não trabalhavam em conjunto. Durante o período de ocupação francesa, Junot utilizou a Impressão Régia de Lisboa como instrumento de propaganda do seu governo em Portugal e das vitórias napoleônicas na Europa. A própria Gazeta de Lisboa, folha oficial portuguesa originada em 1715, passou a servir como órgão oficial da governação francesa, passando a ostentar no frontispício a águia imperial no lugar das quinas portuguesas, como ressalta Lúcia Bastos. ${ }^{58}$ Os panfletos políticos que incitavam à resistência aos franceses eram publicados por outras tipografias, como a Oficina de Simão Thadeu Ferreira ou a de Antonio Rodrigues Galhardo. Explica Lúcia Bastos que após a primeira expulsão das tropas francesas do território português, em finais de 1808, e enquanto durou a conjuntura de guerra, a imprensa portuguesa conheceu uma inédita liberdade, com o surgimento de vários jornais, redigidos por diversos autores e incentivados pelos governadores do Reino. Em comum, manifestavam o ódio contra a França e a intenção de reforçar a vontade de resistência dos

\footnotetext{
${ }^{56}$ O naturalista italiano só conseguiu retornar a Portugal em 1815, após seu filho, Alexandre Antonio Vandelli, português de nascimento, interceder a seu favor junto ao Príncipe Regente (FILGUEIRAS, C. A. L. e MARQUES, A. J. O Químico e Naturalista luso-brasileiro Alexandre Antonio Vandelli, p. 2493).

57 Segundo a definição de Lúcia Bastos, os panfletos políticos se caracterizavam por ser publicações mais ágeis e baratas que os jornais: "os folhetos e os panfletos eram pequenos livretos, algumas vezes não encadernados, que, dependendo de seu formato - in-fólio, in-quarto ou inoitavo -, possuíam tamanhos diversos. Podiam publicar páginas e réplicas rápidas, mas também podiam abrigar escritos mais longos e reflexivos. Literatura de circunstância por excelência, essas obras cumpriam o papel de levar notícias e informações a uma platéia mais ampla, que deixava de vê-las como meras novidades do domínio privado para encará-las como parte de um espaço comum, esboçando-se a formação de uma esfera pública de poder". NEVES, L. B. P. das; VAINFAS, R. Dicionário do Brasil Joanino - 1808-1821, p. 362.

${ }^{58}$ NEVES, L. M. B. P. das. op. cit., p. 242.
} 
portugueses: "Passado o perigo, porém, retornava a censura aos jornais e renascia o antigo privilégio da Gazeta de Lisboa de publicar com exclusividade as novidades do estrangeiro., 59

Uma dessas publicações era a Memória Histórica da Invasão dos francezes em Portugal no ano de 1807, de autoria de D. José Caetano da Silva Coutinho. Bacharel em Direito pela Universidade de Coimbra, foi nomeado bispo do Rio de Janeiro em 1805. Tendo ido sagrar-se em Lisboa em 1807, lá se encontrava ainda por ocasião da invasão do Reino pelas tropas de Junot. Não tendo conseguido sair de Portugal junto com a esquadra que levou a Família Real para o Brasil, Silva Coutinho escapou clandestinamente apenas em 4 de março de $1808 .{ }^{60}$ Segundo informação do próprio autor, a sua Memória Histórica foi escrita ainda naquele mesmo mês, provavelmente após seu embarque para o Rio de Janeiro, mas a sua publicação ocorreu apenas em outubro de 1808, pela Impressão Régia do Rio de Janeiro, quando já havia começado a primeira expulsão dos franceses do território português:

Quando se escreviam estas palavras, em março de 1808, ninguém poderia adivinhar que o monstro da Córsega chegasse a detronizar com tanta brevidade e com tão vil perfídia a Família Real de Espanha e a cometer os outros crimes tão horrendos e intoleráveis que puseram nas mãos de todos os habitantes da Península daquém dos Pirineus as armas da vingança e do entusiasmo. A Revolução de Espanha conduziu necessária e imediatamente à Revolução de Portugal; e nela temos o inexplicável prazer de ver verificadas pelos fatos as principais circunstâncias do nosso prognóstico na presente Memória: pois que já hoje, em outubro de 1808, temos visto que os portugueses têm desenvolvido as virtudes e o caráter do mais heróico patriotismo, com que havíamos contado com toda certeza; que era impossível que esta briosa nação sofresse por muito tempo a tirania e o julgo infame de uns ladrões estrangeiros. ${ }^{61}$

Na sua Memória, Silva Coutinho narra os acontecimentos entre a partida do Príncipe Regente e a sua própria saída de Portugal, como se observasse aquilo que descreve. Porém, o autor reproduz diálogos que certamente não presenciou, devendo tê-los escutado de terceiros ou mesmo criado a partir da própria imaginação. O que ressalta o caráter da sua Memória como trabalho de

\footnotetext{
${ }^{59}$ Ibid., p. 242/243.

${ }^{60}$ Como afirma na sua Memória Histórica: "Igualmente, nos achamos na impossibilidade de referir outros fatos sucedidos depois do dia 4 de março, dia feliz da nossa saída do Tejo". COUTINHO, J. C. da S. Memória Histórica da Invasão dos francezes em Portugal no ano de 1807, p. 73.

${ }^{61}$ Ibid., p. 80/81.
} 
representação seletiva do passado. Não obstante, o seu trabalho acabou por estabelecer algumas interpretações que se tornaram canônicas acerca dos acontecimentos daquele período. Coutinho chama bastante a atenção, ao longo da sua narrativa, para os exemplos de colaboração com os franceses por parte da nobreza portuguesa, não se furtando a registrar o nome dos colaboracionistas, como por ocasião de vivas dados a Napoleão no Teatro de S. Carlos:

Deve-se notar que neste clamor se distinguiu a voz de um Sargento Mor de Cavalaria do Regimento dos Noturnos, porque todos os mais portugueses que ali se achavam vieram saindo para fora mudos e envergonhados. Deve, igualmente, notar-se que nessa noite o Sargento Mor e o Desembargador Azevedo, que era Procurador da Real Fazenda, iluminaram as frontarias de suas casas. Talvez que estes sujeitos, e outros semelhantes, não gostem muito que se fale e se escreva o seu procedimento, mas devem refletir que se não queriam que se publicassem suas ações, deviam eles mesmos ocultá-las, e não acender luzes para que todo o mundo as visse. ${ }^{62}$

$\mathrm{Na}$ sua relação dos colaboradores de Junot, a narrativa de Coutinho talvez seja a mais antiga a construir a reputação do Marquês de Alorna e de Gomes de Freire de Andrade como dois dos principais colaboradores dos franceses. Infâmia que os acompanhou até depois da morte:

Entretanto, aqueles que se acham empregados no serviço, tanto oficiais como soldados, por gosto ou por política, acompanharam o general francês e governador do Reino na sua pomposa parada do costume, no dia 21 de fevereiro, sendo os primeiros entre eles o Marquês de Alorna e Gomes Freire. ${ }^{63}$

Ao comentar o episódio da deputação enviada a Bayonne para encontrar com Napoleão, Coutinho talvez tenha sido também o primeiro a construir por escrito a memória desse acontecimento como ele viria a ser interpretado posteriormente. O de uma deputação da primeira nobreza do Reino que ia, em

\footnotetext{
${ }^{62}$ Ibid., p. 34. Mais adiante, Coutinho se refere a banquetes dado por Junot e frequentados por figuras da nobreza portuguesa e vice-versa, banquetes oferecidos pela nobreza portuguesa aos generais franceses: "Poucos dias depois se deu em casa de José de Seabra um famoso jantar ao General Kellerman com o pretexto de que era seu parente, a que assistiram mais alguns franceses e senhoras portuguesas. Bebeu-se muito à saúde do Grande Napoleão, notando-se que todos se levantaram em pé, à exceção de duas senhoras, que ficaram sentadas". Ibid., p. 46.

${ }^{63}$ Ibid., p. 66. Segundo o autor, Alorna havia sido nomeado, a 2 de fevereiro, por ocasião da formação do governo de Junot, General das Províncias da Extremadura, Beira e Minho; enquanto Gomes Freire o fora para general das outras três províncias: Alentejo, Algarve e Trás-os-Montes. Explica Lúcia Bastos que Gomes Freire participou como voluntário das guerras no Império Russo, entre 1788-1792 e seguiu para a França em 1808, junto com Alorna e os demais oficiais, assumindo a direção efetiva da Legião Portuguesa. Participou da campanha da Rússia, quando foi feito prisioneiro, retornando a Paris em 1814-1815. Após a paz geral, voltou a Portugal para recuperar seus bens, mas acabou executado como chefe da conspiração de 1817 (NEVES, L. M. B. P. das, op. cit., p. 205).
} 
verdade, solicitar um novo soberano francês para Portugal. Versão que, segundo ele, já era moeda corrente entre a população de Lisboa:

Alguns portugueses pretendem que estes enviados vão juntamente incumbidos de suplicar ao Imperador algum rebate favorável na contribuição dos quarenta milhões, e não querem duvidar que, por fanfarronada, Bonaparte deixe de anuir em parte às suas humildes súplicas. Mas a opinião de quase todos, e que parece a mais bem fundada, é (...) que vão pedir um novo rei para Portugal. E este rei, já se preconiza que deve ser Luciano Bonaparte. ${ }^{64}$

O último capítulo da Memória de Silva Coutinho é dedicado a considerações a respeito da reconstrução do Império português na América. O bispo cronista fazia uma avaliação extremamente positiva da decisão tomada pelo Príncipe Regente, acenando com a possibilidade de um próspero futuro para a monarquia nos trópicos. Segundo ele, gloriosas empresas estavam reservadas para os portugueses da América: "Não é nada menos que a fundação de uma nova monarquia poderosa e respeitável por mar e por terra, a primeira monarquia do Novo Mundo!". ${ }^{65}$ Para tanto, era necessário apenas seguir uma política sem ambiguidades, de aliança com a Inglaterra e guerra contra a França e os seus colaboradores no Reino. Importante lembrar que o decreto de D. João declarando guerra à França foi publicado apenas em 1 de maio de 1808. Depois, portanto, de Silva Coutinho ter escrito a sua Memória, mas antes da Impressão Régia tê-la publicado. $^{66}$

O panfleto intitulado Reflexões sobre a conduta do Príncipe Regente de Portugal, publicado em Portugal em 1808, e no Rio de Janeiro logo no ano seguinte, também avalia positivamente a decisão de transferir a corte para a América. A autoria do panfleto é atribuída a Francisco Soares Franco, porém Rubens Borba de Moraes e Ana Maria de Almeida Camargo afirmam ser uma

\footnotetext{
${ }^{64}$ COUTINHO, op. cit., p. 75.

${ }^{65}$ Ibid., p. 83.

66 "Cumpre abandonar e esquecer-se absolutamente de toda a espécie de convenção, de tratado de trégua ou de paz com uma raça de gentes que professa a traição e a perfídia. Não convém hoje ao Brasil um sistema de neutralidade ou de ambigüidade que mostre uma certa espécie de fraqueza, e que dá sempre azos e confianças ao inimigo vitorioso e atrevido; cumpre mostrar um caráter decidido e protestar à face de todo o mundo uma aliança firme com a Grã-Bretanha, entrar cordialmente nos seus sentimentos de liberdade e de independência, acompanhá-la em seus projetos, tomar parte em suas empresas, fazer causa comum e receber dela a força e o socorro de que se precisa. Cumpre estabelecer no Brasil uma certa tolerância política que chame para o novo Estado as artes e a indústria, as famílias e os artífices desgostosos de todas as nações da Europa, exceto os franceses e, mesmo, os portugueses afrancesados, que devem banir-se ou, cuidadosamente, vigiar-se". Ibid., p. 85/86.
} 
tradução de um panfleto de autor anônimo publicado em Londres em 1807, em idioma francês cujo título era Reflexions sur la conduit du Prince Regent de Portugal. ${ }^{67}$ A leitura do texto em português sugere que ele tenha sido escrito antes da transferência da corte, ou logo após aquele acontecimento:

Bonaparte conhece de um golpe de vista o que será para a América esta nobre emigração de um Rei de Portugal, seguido de seus vassalos fiéis, indo a mostrar a estes povos do Novo Mundo um rei da Europa que vem residir no meio deles para fugir ao envilecimento e à tirania e, abandonando esta Europa, que veio a ser um verdadeiro asilo de ignomínia debaixo do cetro de um corso. ${ }^{68}$

Segundo a argumentação do autor do panfleto, apenas três reis europeus tiveram a coragem de combater os planos de Napoleão, "seguindo nos nossos tempos modernos as antigas virtudes dos reis que não existem senão na história": ${ }^{69}$ George III, da Inglaterra, Gustavo IV, da Suécia e D. João, de Portugal. Os dois últimos, os mais fracos em território dos reis da Europa, “ensinam a esses grandes reis, hoje prostrados debaixo do trono de Bonaparte, que recursos tira um grande coração da sua desesperação e como, quando se despreza a morte, se conserva o seu poder e se segura a glória". ${ }^{70}$ Em uma avaliação das potencialidades do império português muito parecida com a que fizeram D. Luiz da Cunha e D. Rodrigo de Sousa Coutinho ainda no século anterior, o autor apontava a debilidade do Reino na Europa:

O Portugal, Estado fraco e à disposição de seus vizinhos não é mais que um acessório da potência portuguesa. (...) É no Brasil que Portugal é uma potência, e é no Brasil que existe o seu inexpugnável baluarte contra a tirania da Europa; é no Brasil que, libertado da tirania de Bonaparte e da ignomínia da Espanha, ele pode puni-los, um dos seus crimes e outro de sua fraqueza, e vingar-se de todos os males que um e outro terão querido acumular sobre Portugal. ${ }^{71}$

Por isso, afirma o autor não conhecer "resolução maior, mais magnânima, nem mais útil em todos os seus resultados", do que a do príncipe regente de

\footnotetext{
${ }^{67}$ CAMARGO, A. M. de A.; MORAES, R. B. de. Bibliografia da Impressão Régia do Rio de Janeiro, p. 33. Sua publicação pela Impressão Régia do Rio de Janeiro é anunciada na Gazeta do Rio de Janeiro de 15 de julho de 1809, onde se sugere que um grande volume de panfletos daquele tipo estavam sendo então publicados: "Saiu à luz: Reflexões sobre a conduta do Príncipe Regente de Portugal, Senhor, etc. Vende-se por 240 réis na loja de Paulo Martin, filho, na Rua da Quitanda $\mathrm{n}^{\mathrm{o}} 34$, aonde se acham todos os folhetos que tem saído". Gazeta do Rio de Janeiro, n ${ }^{\circ} 88,15$ de julho de 1809.

${ }^{68}$ FRANCO, F. S. Reflexões sobre a conduta do Príncipe Regente de Portugal, p. 9.

${ }^{69}$ Ibid., p. 6.

${ }^{70}$ Ibid.

${ }^{71}$ Ibid., p. 7.
} 
Portugal de se transferir para a sua colônia na América. Dessa forma, também na re-presentificação de Francisco Soares Franco, ou de quem quer que seja o autor anônimo do panfleto, a interpretação do presente de Portugal apontava para o projeto de reconstrução da monarquia na América:

O Príncipe do Brasil examina de um golpe de vista donde vem a Bonaparte a audácia de lhe fazer proposições que um rei não deve jamais ouvir e conhece que a posição de Portugal é a base da insolência do seu inimigo. Conhece, ao mesmo tempo, o perigo e as consequiências; é o Brasil a quem ele vai confiar a sua honra, a sua segurança, sua glória e a do nome português. ${ }^{72}$

Apesar de apresentarem diferenças qualitativas nas circunstâncias da sua produção, os panfletos políticos que comentavam a decisão do Príncipe-Regente, via de regra, procuravam justificá-la, interpretando-a como uma sábia e necessária decisão tomada em boa hora, de modo a que aparecesse como menos traumática para os portugueses dos dois lados do Atlântico. Fundamental para essa interpretação era a relação que essas publicações estabeleciam entre aquela decisão e acontecimentos posteriores, principalmente a abertura dos portos, entendida como sua principal conseqüência e promessa de prosperidade para o Império, como visto no capitulo anterior. Dessa forma, se o trabalho de representificação deve ser compreendido a partir da relação que estabelece entre passado, presente e futuro, como sugere Fernando Catroga, é importante atentar para a relação que a memória da transferência estabelece entre essas três dimensões; relacionando-a, por um lado, com o passado glorioso do Império português, marcado pelas navegações e a descoberta do Novo Mundo; e, por outro lado, com o projeto de reconstrução da monarquia elaborado pela Ilustração portuguesa, do qual os acontecimentos presentes da transferência da Corte e a Carta Régia de abertura dos portos, apareciam como os primeiros passos.

É dessa forma que o assunto é abordado também na Gazeta do Rio de Janeiro. No primeiro número do periódico o redator comenta notícia publicada no Le Moniteur, gazeta oficial do governo francês, em que se afirmava que se não quisesse se submeter à França não haveria outra saída para o rei da Suécia "senão de ir reinar para alguma parte da América”. Rebatendo aquilo que considerou uma insinuação sobre a situação da monarquia portuguesa, o redator da Gazeta valoriza a decisão do monarca português, chamando a atenção para os efeitos da

\footnotetext{
${ }^{72}$ Ibid. "Ibid., p. 8.
} 
Carta Régia de abertura dos portos e recuperando, ao mesmo tempo, a idéia do Império Português como uma herança preservada e transmitida desde o século $\mathrm{XV}$. Interliga, dessa forma, o passado, o presente e o futuro da monarquia portuguesa:

Se esta frase do Monitor envolvesse alguma insinuação a nosso respeito, responder-se-lhe-ia: reinamos na melhor porção da América e a prova disso são os sábios atos do governo do Nosso Amado Soberano. O Príncipe Regente Nosso Senhor imediatamente depois da sua chegada mandou abrir os portos destes seus domínios a livre comércio de todas as nações amigas e declarou guerra àquela que invadiu aleivosamente o patrimônio que transmitiu o primeiro dos nossos reis à Sua Augusta Família Real, na cessão do qual jamais consentirá, e sobre o qual conservará sempre os mesmos [ilegível] que tem ao vasto império que herdou do Senhor Rei D. Manoel. ${ }^{73}$

Alguns números depois, em texto no qual comemora a restauração do Algarve e caracteriza a invasão francesa como ato de traição, o redator da Gazeta volta a elogiar a decisão de transferência da sede do reino para o Brasil, caracterizando o fato como um exemplo de resistência às pretensões francesas sobre a Europa, que o monarca português propiciou aos outros soberanos europeus; ao mesmo tempo em que o relaciona, mais uma vez, aos efeitos positivos da sua principal consequiência, a abertura dos portos:

\begin{abstract}
Portugal, constantemente fiel à letra dos seus tratados, merecia ser poupado. Mas a política francesa tresvaria. $\mathrm{O}$ seu chefe, semelhante àquele que de uma eminência altíssima, contemplando os objetos inferiores, os vê confusos e incertos, depois que chegou ao cúmulo do poder, ofuscadas suas vistas, não atina com os meios, e os que emprega são, felizmente, os que vão retorquindo contra ele os males que contra os outros projeta. Se ele ameaçava todos os dias a Portugal com uma invasão, era só porque esperava que não se realizasse a generosa resolução que o Príncipe Regente N.S. tinha formado de se refugiar no Brasil, a qual contrariou a França de dois modos: por um lado fez com que o exemplo magnânimo que S.A.R. ofereceu às nações despertasse nelas (como em Espanha) a devida energia; por outro lado, fez com que as produções deste vasto continente do Brasil nos abrisse uma fonte de prosperidade no comércio franco de todas as nações, e principalmente daquela que o Imperador dos franceses procura esmagar. ${ }^{74}$
\end{abstract}

As avaliações positivas da transferência, porém, não eram unânimes. Autores como José Acúrsio das Neves, para quem a transferência da Corte e a abertura dos portos da América portuguesa eram considerados a causa da decadência política e econômica do antigo Reino, como vimos no capítulo

\footnotetext{
${ }^{73}$ Gazeta do Rio de Janeiro, $\mathrm{n}^{\mathrm{o}} 1,10 / 09 / 1808$.

${ }^{74}$ Gazeta do Rio de Janeiro, no $5,28 / 09 / 1808$.
} 
anterior, avaliavam esses acontecimentos de forma bem diversa. Como referido no capítulo precedente, entre 1808 e 1810 Acúrsio dedicou-se à redação de 12 panfletos políticos que, publicados primeiramente em Portugal, encontraram amplo espaço para a sua reedição também no Rio de Janeiro (ao contrário da sua obra sobre Economia Política), e que ostentavam títulos sugestivos tais como: $O$ Despertador dos Soberanos e dos Povos; Manifesto da razão contra as usurpações francesas; Reflexões sobre a invasão dos franceses em Portugal; A Salvação da Pátria. Proclamação aos portugueses sobre a sua honra e o seu dever nas atuais circunstâncias da monarquia ${ }^{75}$ Escrita no calor do momento, o traço distintivo da sua obra patriótica, como Acúrsio mesmo a chamava, é uma constante exortação dos povos ibéricos à guerra contra a França, o que a torna qualitativamente distinta dos já comentados panfletos do Bispo Silva Coutinho e da tradução de Francisco Soares Franco. Como essa, por ocasião da segunda invasão francesa a Portugal, comandada pelo General Nicolas Jean-de-Dieu Soult:

Nada de escravidão, briosos portugueses, que não nascestes para serdes tratados como bestas. Não vos deixeis iludir com as proclamações com que esse enviado do Usurpador, o Marechal Soult, tem querido enganar os habitantes das províncias do Norte (...). Perguntai a vós mesmos pela proteção que achastes no exército de Junot, tendo entrado como amigo e aliado, e julgai a que podereis esperar de Soult, que entra a ferro e fogo, e tem a vingar os caprichos de Napoleão, a injúria das águias e o destroço dos invencíveis? Junot e Soult são alunos da mesma escola. ${ }^{76}$

No Manifesto da razão contra as usurpações francesas, Acúrsio constrói

\footnotetext{
${ }^{75}$ É possível encontrar o anúncio de publicação dos seus panfletos pela Impressão Régia do Rio de Janeiro na Gazeta do Rio de Janeiro. Os reiterados anúncios das obras de Acúrsio das Neves indicam que o autor tinha uma boa aceitação junto aos leitores no Rio de Janeiro: "Saiu à luz: $O$ Despertador dos Soberanos e dos Povos. Vende-se na loja da Gazeta por 800 réis. Na mesma ainda se acham alguns exemplares da bem aceita obra Manifesto da razão contra as usurpações francesas, por 640 réis" (Gazeta do Rio de Janeiro, $\mathrm{n}^{\circ}$ 104, 9 de setembro de 1809). Na edição seguinte, a seção de Avisos anuncia: "Saíram à luz: Obras completas de José Acursio das Neves, sete folhetos, por 3.600 réis, que contem as seguintes peças, e se vendem avulsas na loja da Gazeta: O Despertador dos Soberanos e dos Povos, com um post scriptum ao mesmo, por 800 réis - Manifesto da razão contra as usurpações francesas, por 640 réis - Três peças patrióticas, por 480 réis - Reflexões sobre a invasão dos franceses em Portugal, por 800 réis - A Generosidade de George III e a ambição de Bonaparte, por 320 réis - A Salvação da Pátria. Proclamação aos portugueses sobre a sua honra e o seu dever nas atuais circunstâncias da monarquia, por 320 réis - Observações sobre os últimos acontecimentos das Províncias de Entre D'Ouro e Minho e Trásos-montes, por 320 réis" (Gazeta do Rio de Janeiro, $\mathrm{n}^{\circ}$ 105, 13 de setembro de 1809). A 25 de novembro, o periódico volta a anunciar a disponibilidade dos panfletos de Acúrsio: "Saiu à luz: Verdadeira Vida de Bonaparte. Vende-se na loja da Gazeta a 960 réis em brochura; onde se acham as obras de José Acursio das Neves, 7 folhetos por 3.600 réis" (Gazeta do Rio de Janeiro, ${ }^{\circ}{ }^{126}$, 25 de novembro de 1809).

${ }^{76}$ NEVES, J. A. das. A Salvação da Pátria. Proclamação aos portugueses sobre a sua honra e o seu dever nas atuais circunstâncias da monarquia, p. 10.
} 
talvez a mais antiga representação textual do episódio do embarque de D. João em novembro de 1807 de que se tem conhecimento, esforçando-se por demonstrar o quão penoso deve ter sido aquele momento tanto para o monarca quanto para o povo português. Escrevendo desde um Portugal abandonado pelo seu rei, a narrativa da transferência se reveste de um tom heróico, porém também dramático; bem diferente do tom predominantemente comemorativo e esperançoso das re-presentificações citadas anteriormente:

Portugal é invadido e o nosso Augusto Soberano se vê reduzido à dura necessidade de abandonar repentinamente a sua Capital, a sua pátria, o seu Reino, para se refugiar naquela parte dos seus Estados que pela sua situação lhe prometia mais segurança. Eu vi este amável Príncipe e toda a Família Real (...) embarcarem fugitivos no coração do inverno, procurando na inconstância das ondas o asilo que a terra lhes negava: as lágrimas que corriam dos seus Reais olhos eram os penhores mais sinceros do seu amor para com os seus vassalos. Eu vi cobertas as praias de imenso povo, que feria o Céu com seus justos clamores; vi entulhados de gente os navios que se achavam prontos a dar à vela, e entulhar-se-ão quantos houvesse, porque a Nação inteira (...) queria precipitar-se sobre os passos do seu adorável soberano. Lisboa, se pudesse, seria uma nova Tróia que, fugindo às ruínas de um continente assolado, iria transplantar os restos escapados ao incêndio nas remotas praias do Novo Mundo. Eu presenciei os últimos adeuses dos maridos e dos pais fugitivos às esposas e aos filhos que ficavam; eu vi, enfim, o dia mais horroroso que tem luzido aos meus olhos. O ar, de tranqüilo, se tornou tempestuoso. Parece que a própria natureza se cobriu de luto. ${ }^{77}$

Sua principal obra sobre o tema, a História Geral da Invasão dos Franceses em Portugal e da Restauração deste Reino, escrita em 5 volumes entre 1810 e 1811, não consta ter sido reeditada pela Impressão Régia, mas certamente era conhecida no Rio de Janeiro, pois vendia-se na Loja da Gazeta, segundo anúncio na edição de 15 de abril de 1815 da Gazeta do Rio de Janeiro. ${ }^{78}$ Nesta obra, Acúrsio faz a descrição dos antecedentes das invasões francesas e narra a primeira invasão e o governo de Junot em Portugal, escrevendo uma representação mais elaborada do embarque, como se ele mesmo tivesse presenciado os fatos, onde acentua o tom de dramaticidade da cena:

\footnotetext{
${ }^{77}$ NEVES, J. A. das. Manifesto da razão contra as usurpações francesas, oferecido à nação portuguesa, aos soberanos e aos povos, p. 19 a 21.

78 "Obras de José Acursio das Neves, secretário atual da Real Junta do Comércio, que se acham na loja da Gazeta. - História da Invasão dos Franceses em Portugal e de sua Restauração, em 5 vol. por 4:800 réis, Variedades sobre objetos relativos a Comércios, Fabricas e Artes, 1 vol. 3:200; Manifesto da razão contra as usurpações francesas, 1 vol. 640; Despertador dos Soberanos, 1 vol. 800; Reflexão sobre a invasão dos franceses, 1 vol. 960; Salvação da Pátria, 320; Generosidade de George III, 320" (Gazeta do Rio de Janeiro, $\mathrm{n}^{\circ}$ 30, 15 de abril de 1815). Interessante notar como ainda se vendia no Rio de Janeiro, em 1815, os panfletos políticos de Acúrsio escritos durante a primeira invasão francesa de Portugal.
} 
Amanheceu finalmente o dia 27 de novembro aprazado para o embarque e a aurora perdeu todos os seus encantos sobre o horizonte de Lisboa neste dia funesto. Os meus leitores me desculparão se acharem que me desvio por alguns instantes daquele estilo singelo que é próprio do historiador: os acontecimentos em que agora se exercita a minha pena são assaz extraordinários para deixarem de ocupar algumas páginas; e quem poderia separar deles as cores patéticas que os caracterizam? Apareceram com o dia pelas ruas, pelas praias de Belém, bandos errantes de pessoas de ambos os sexos e de todas as idades, em cujos rostos estavam pintadas a mágoa e a desesperação; chegou a temer-se que, no excesso da sua dor, rompessem em algum desatino contra os que julgavam culpados na desgraça pública. $\mathrm{Na}$ verdade, o ajuntamento não era ainda demasiado quando apareceu a primeira carruagem da Casa, na qual eram conduzidos S.A.R. o Príncipe Regente e o infante de Espanha, o Senhor D. Pedro Carlos; tanto em razão da distância da cidade a Belém, como por se ignorarem as horas em que as pessoas reais deviam embarcar; mas foi crescendo, e quando aquele Augusto Senhor se apeou sobre o cais, tudo parecia querer precipitar-se sobre ele, e de forma que na descida dos degraus the era necessário ir fazendo com o braço a ação de desviar o povo que o rodeava. O largo não estava ainda guarnecido de tropa, e até o piquete de cavalaria que acompanhava a S.A.R. se demorou alguns minutos; serviram-lhe de guarda dois soldados do corpo de polícia que ali se achavam.

Ao aspecto deste príncipe adorado dos seus vassalos, e agora tão consternado e abatido, todos emudeceram, e as próprias lágrimas lhes ficaram tolhidas, mas a dor bem pintada nos seus semblantes. Não era menos tocante a aptidão do Príncipe: os seus pés trêmulos e sem firmeza mal podiam sustentar o seu corpo vacilante: o físico sentia as impressões violentas do moral. Seu rosto nadava em lágrimas, porque os seus olhos eram duas torrentes. E assim foi levado ao escaler. E neste à esquadra, sendo os adeuses que dava ao seu povo mais e mais lágrimas que lhe caíam. ${ }^{79}$

A re-presentificação dos fatos que ele constrói aponta para uma relação diferente entre o passado, o presente e o futuro do Império Português. Se o passado português continuava sendo glorioso, seu futuro, porém, não era nada esperançoso, pois a transferência aparecia como uma ruptura entre aquelas dimensões temporais. A sua perspectiva, certamente, apontava para outro projeto para o Império Português, e talvez aí se encontre uma razão para a não publicação da sua História Geral pela Impressão Régia do Rio de Janeiro. Outra explicação pode ser a presença naquela obra de acusações nominais de colaboracionismo a figuras notórias do Reino por ocasião daquela invasão. Acusações essas que não seria adequado divulgar na Corte do Rio de Janeiro depois de expulsos os franceses e pacificado o Reino.

Como, por exemplo, a acusação que faz a Francisco de Borja Garção Stockler (1759-1829). Como explica Lúcia Bastos, Stockler, que era conselheiro

\footnotetext{
${ }^{79}$ NEVES, J. A. História Geral da Invasão dos Franceses em Portugal e da Restauração deste Reino, v. 1, p. 172 a 174.
} 
militar do Duque de Lafões e secretário da Academia Real das Ciências de Lisboa, foi um dos acusados por Acúrsio de colaborar com os franceses, pelo seu envolvimento no episódio do convite feito a Junot para assumir a presidência daquela instituição. Em 1813, já em solo americano, Stocker publica pela Impressão Régia do Rio de Janeiro as suas Cartas ao autor da História Geral da Invasão dos franceses em Portugal e da Restauração deste Reino. Enquanto Marechal de Campo dos Reais Exércitos portugueses, nas suas nove cartas Stockler faz correções dos fatos relativos às campanhas da guerra contra os franceses e expõe os princípios militares que lhes serviram de base. Mas a principal intenção do seu escrito teria sido, de fato, segundo Lúcia Bastos, se justificar das acusações de colaboracionismo, rebatendo as críticas e falsidades, nas suas palavras, inventadas por Acúrsio. ${ }^{80}$ Apesar de ter sido proibido por D. João de aparecer na Corte logo que chegou no Rio de Janeiro em 1812, a crer nas palavras do bibliotecário Luiz Joaquim dos Santos Marrocos, ${ }^{81}$ Stockler parece ter sido bem sucedido no seu intento de limpar o seu nome, uma vez que, ao contrário

\footnotetext{
${ }^{80}$ NEVES, op. cit., p. 213/214. A publicação do escrito de Stockler foi comentada na edição de $O$ Patriota de junho do mesmo ano. Manuel Ferreira de Araújo Guimarães, redator do periódico, se declara discípulo e amigo de Stockler a quem faz tamanho elogio que diz temer que se tome por suspeita a resenha que então escrevia sobre a sua obra. Não deixa por isso, todavia, de recomendar a obra: "Eu estou persuadido que nenhum futuro escritor poderá recusar o seu testemunho sobre estes fatos, que tanto lugar hão de ocupar na História. (...) O leitor instruído achará nesta obra uma fonte abundantíssima de novos conhecimentos e de recursos, que o seu zelo possa pôr em prática a benefício da Pátria" ( $O$ Patriota, $\mathrm{n}^{\circ}$ 6, junho de 1813, p. 92/93). O anúncio da obra de Stockler feito na Gazeta do Rio de Janeiro, cujo redator era o mesmo Araújo Guimarães, mantém o mesmo tom de defesa do autor: "Saiu à luz Cartas ao autor da História Geral da Invasão dos Franceses em Portugal e da Restauração desta Monarquia, por Francisco de Borja Garção Stockler, fidalgo da Casa de S. A. R., Marechal de Campo dos Seus Exércitos, etc. Nas quais se convencem os descuidos e erros do autor relativamente à campanha do ano de 1801, e se justifica a conduta da Academia Real das Ciências de Lisboa, e a do próprio autor, durante a dominação francesa, injustamente desfiguradas na sobredita obra" (Gazeta do Rio de Janeiro, $\mathrm{n}^{\circ} 48,16$ de junho de 1813).

${ }^{81} \mathrm{Na}$ sua carta para o pai de 29 de agosto de 1812, afirma Luiz Joaquim dos Santos Marrocos que, na mesma noite em que desembarcou no Rio, Stockler se apressou em ir beijar a mão do monarca português. Nessa mesma ocasião "teve insinuação particular para não aparecer mais na presença de S.A.R. até segunda ordem" (Cartas de Luiz Joaquim dos Santos Marrocos, escritas do Rio de Janeiro à sua família em Lisboa, de 1811 a 1821, p. 96). Um ano depois, Marrocos volta a falar da situação de Stockler na corte, se referindo aos possíveis motivos pelos quais ele teria sido banido da Corte e aludindo à publicação do seu livro. A opinião de Marrocos acerca de Stockler é bastante diferente daquela do redator de O Patriota e da Gazeta: "A respeito de Stockler, já em outra informei a V.M. ${ }^{\text {ce }}$ de ele ter chegado inesperadamente para servir onde S.A.R. houvesse por bem empregá-lo. Eu não o vejo ir ao Paço, e afirmam que não tem beijado a mão a S.A.R.. Ele vive em retiro fora da cidade, inculca muito de sua conduta exemplar no tempo do intruso governo e publicou uma obra - Cartas ao autor da História Geral da Invasão dos Franceses em Portugal e da Restauração deste Reino. Rio de Janeiro. 1813 - $4^{\circ}$ - em que pretende justificar-se com muita palavrada ou parolada, assim como o seu Plano de Campanha com o Duque de Lafões; porém, é tão infeliz que cada vez se condena mais e se atola no lodo" (Ibid., p. 159).
} 
do que aconteceu a Vandelli e aos outros perseguidos de 1809 e 1810, foi agraciado com o cargo de Desembargador do Desembargo do Paço e Censor Régio em 1818, segundo Tereza Cristina Kirschner. ${ }^{82}$

Mesmo após a expulsão definitiva dos franceses do Reino, representificações da transferência da corte para o Rio de Janeiro continuaram a ser escritas, agora como forma de justificar a permanência do monarca na América após o fim da guerra na Europa. Como dito no início desse capítulo, o tema domina a Memória dos benefícios políticos do Governo de el-rey Nosso Senhor D. João VI, de José da Silva Lisboa, publicada em 1818. A Memória de Silva Lisboa apresenta uma narrativa bem mais elaborada do que os panfletos analisados anteriormente, apesar de apresentar algumas interpretações em comum com aqueles, como a relação que estabelece entre o passado, presente e futuro da Monarquia portuguesa. Como ressalta Antônio Penalves Rocha, não há termos de comparação entre as análises históricas atuais sobre a transferência da Família Real e a re-presentificação daquele acontecimento feita por Silva Lisboa. Seus escritos não aludem aos interesses ingleses em Portugal, nem tampouco à necessidade inglesa de salvaguardá-los, dando segurança à Monarquia no Brasil, para que a Inglaterra mantivesse o domínio econômico sobre o mundo lusitano. ${ }^{83}$ O elogio da medida, classificada como "heróico sacrifício", ${ }^{84}$ é feito por uma comparação com outros exemplos históricos não apenas do Império Português, mas de impérios mais antigos, maiores e mais poderosos. Silva Lisboa compara a estratégia de D. João à do Imperador Constantino que, fundando Bizâncio, concedeu uma sobrevida ao Império Romano:

Obrou com a previdência de Constantino Magno que, para melhor sustentar a majestade do Império contra as traições de rivais, transpôs-se do Tibre ao Bósforo, firmando a sede do trono no melhor porto do Helesponto, fundando Bizâncio, deixando arvorada a bandeira do Cristianismo no capitólio de Roma. ${ }^{85}$

\footnotetext{
${ }^{82}$ KIRSCHNER, T. C. José da Silva Lisboa, Visconde de Cairu: Itinerários de um ilustrado lusobrasileiro, p. 155. Stockler solicitou a D. João dispensa do cargo de Censor Régio em documento datado de 1820. Motivado, segundo Leila Mezan Algranti, por uma polêmica em que se envolveu com o escrivão da Câmara do Desembargo do Paço, Bernardo José de Sousa Lobato, acerca da liberação de uma remessa de livros que se encontrava na Alfândega do Rio de Janeiro (ALGRANTI, L. M. Nos bastidores da censura: os "homens bons" do paço, p. 234 a 245). Desde 12 de novembro de 1819, no entanto, Stockler já se encontrava nomeado para exercer a função de Governador e Capitão-General dos Açores. Cargo que assume em 18 de outubro de 1820.

${ }^{83}$ ROCHA, A. P. A Economia Política na Sociedade Escravista, p. 103.

${ }^{84}$ LISBOA, op. cit., p. 38.

${ }^{85}$ Ibid., p. 74.
} 
Porém, na narrativa de Silva Lisboa a transferência da Corte para o Rio de Janeiro não foi somente o produto de um engenhoso cálculo político de D. João, mas a realização de uma ordem divina:

O Príncipe do Brasil, sendo informado do real estado das coisas, levantando os olhos ao Céu e pondo o seu destino nas mãos do Onipotente, obrou como o pai dos crentes quando ouviu a voz superior - Sai da tua terra: dar-te-hei a Terra da Promissão. ${ }^{86}$

Lançando mão de uma concepção providencialista de História, a transferência da sede da monarquia aparece como predestinação e D. João, consequentemente, como um monarca predestinado. Ideia na qual estava inclusa a de que D. João foi escolhido por Deus para servir de exemplo de resistência à ambição napoleônica para os outros soberanos europeus:

Por incógnitos juízos de Deus, estava reservada a principal honra aos soberanos, amigos e fidelíssimos aliados, de Portugal e Inglaterra, inspirando-lhes o ânimo de, primeiros, darem ao mundo o espetáculo e exemplo de heróica resistência ao inimigo do gênero humano e de uma polícia filantrópica e liberal que imortalizasse os seus governos, deixando Memoriais de agradecimento até a última posteridade. $^{87}$

Repetindo a interpretação feita pelo redator da Gazeta do Rio de Janeiro, o Manifesto de $1^{\circ}$ de maio de 1808 , aparece na Memória de Silva Lisboa como o documento que forneceu o exemplo a ser seguido pelos outros monarcas europeus e como prenúncio da queda de Napoleão: “Os povos e monarcas excitaram-se do letargo com o prognóstico consignado nesse Monumento Diplomático, da final queda do Usurpador". ${ }^{88}$ Consequentemente, um traço distintivo da sua narrativa é a condenação da Revolução Francesa, na qual se misturam razões políticas e econômicas. ${ }^{89}$ Como já foi visto no capítulo anterior, a consequiência necessária da condenação da Revolução Francesa e da cobiça de Napoleão é o elogio da política de aliança com a Inglaterra. Ao abordar o Sistema Defensivo de Portugal

\footnotetext{
${ }^{86}$ Ibid., p. $55 / 56$.

${ }^{87}$ Ibid., p. 39.

${ }^{88}$ Ibid., p. 88.

${ }^{89}$ Nesse ponto, Silva Lisboa repete os seus argumentos econômicos contra a Revolução Francesa, além de construir uma representação negativa de Napoleão, a quem intitula Usurpador e Tigre Corso, e do ideário revolucionário ressaltando a falsidade da "hipócrita proclamação de universal igualdade e liberdade" (Ibid., p. 22), que seriam contrárias à natureza humana e à religião cristã, com as quais os revolucionários franceses iludiram "a crédulos, idiotas e covardes" (Ibid., p. 52): "A Galomania que tentou nivelar todas as classes e indivíduos, desmentindo a Providência, que variou talentos, estados e graus de méritos dos homens; dando tortura à natureza". (Ibid., p. 85)
} 
(que ele denomina como o terceiro benefício político do governo de D. João), essa aliança aparece como uma decisão tomada desde o início do conflito, nunca questionada e embasada na história da monarquia portuguesa:

Lembrava-se das regras de seus predecessores gloriosos, como o Senhor D. João V, que judiciosamente dizia - guerra com todo mundo, paz com Inglaterra -; e do Senhor D. José I, que, no século passado, sendo ameaçado das forças combinadas de Espanha e França, para o mesmo fim iníquo de se desligar do seu fiel aliado, por ultimatum deu a heróica réplica que melhor veria cair a última telha de seu paço que desertar do seu amigo. ${ }^{90}$

$\mathrm{Na}$ re-presentificação feita por Silva Lisboa a recorrência a exemplos retirados da história do Império Português é utilizada como forma de unir o passado, o presente e o futuro de Portugal. Futuro esse que estaria indissoluvelmente ligado à América portuguesa. Ainda na sua Satisfação ao Público, ele utiliza a obra de Camões para comparar a vinda de D. João para o Brasil com a chegada dos portugueses à Índia:

Vendo o complemento do destino de Sua Vinda à esta serena região d'América, segundo aclamou o habitante da Índia, saudando com êxtase a vinda do nosso primeiro Descobridor do Oriente: 'Não é sem causa, não, oculta e escura/Vir do longínquo Tejo e ignoto Minho,/Por mares nunca doutro lenho arados,/A reinos tão remotos e apartados./Deus, por certo, vos traz, porque pretende/Algum serviço seu por vós obrado;/ Por isso só vos guia e vos defende/ Dos inimigos do mar, do vento irado'. ${ }^{91}$

O autor recorre a exemplos históricos também ao abordar a Carta Régia de Abertura dos Portos, caracterizando a medida como um complemento da obra dos primeiros construtores do Império Português:

O Senhor D. João consagrou (se é lícito dizer) a Sua gloriosa vinda ao Seu principado ultramarino no Novo Mundo com a Carta Régia de 28 de janeiro de 1808, abrindo os portos do Estado a todas as nações que estivessem em paz e harmonia com a Coroa - isto nos basta. O Senhor D. Henrique mandou, mas o Senhor D. João veio abrir o comércio do Orbe. ${ }^{92}$

Essa recorrência a exemplos retirados da História de Portugal está

\footnotetext{
${ }^{90}$ Ibid. p. 32.

${ }^{91}$ Ibid., p. VI/VII.

92 Ibid., p. 59. Utilizando exemplos retirados de momentos de glória da monarquia portuguesa, Silva Lisboa utiliza, no seu elogio a Abertura dos Portos, imagens significativas para os habitantes do Império Português: "O Pão de Açúcar se constituiu o segundo, quase fronteiro, Cabo da Boa Esperança, que segurou a salvação da Ordem Civil e a abertura do comércio do Globo. O Senhor D. João aí descarregou hercúleo golpe à Hidra do Jacobinismo e ao Dragão do Monopólio, que haviam atacado as entranhas vitais do corpo social". Ibid., p. 83.
} 
relacionada, por outro lado, à forma como os letrados portugueses de finais do século XVIII e inícios do século XIX se relacionavam com o tempo, imersos que estavam, em sua maioria, no que François Hartog denominou de um regime de historicidade antigo. Nessa forma de experiência temporal, a relação entre passado e futuro era dominada ou regulada por referência ao passado. Se, por um lado, o futuro não apenas reproduzia o passado, por outro lado, também não ia além dele. ${ }^{93}$ Esse regime de historicidade é caracterizado por uma concepção cíclica de tempo. Como explica Valdei Araújo:

Enquanto na França, Inglaterra e Prússia se consolidavam, no início do século XIX, as narrativas legitimadoras da modernidade como progresso linear, no mundo lusobrasileiro a experiência do tempo permanecia presa a modelos cíclicos. Conceitos fundamentais como restauração apresentavam-se ricos em substrato histórico, pois remetiam aos diferentes momentos da "gloriosa" história portuguesa e da esperança de repetir uma sempre reivindicada Idade do Ouro. ${ }^{94}$

Baseada nessa concepção cíclica de tempo, prevalecia a concepção da história como mestra da vida, onde o passado iluminava o futuro e a história, enquanto relato exemplar, deveria fornecer lições sobre como proceder no presente. Essa forma de conceber a relação com o passado aparece na proposta da Memória dos Benefícios Políticos de Silva Lisboa:

Ainda que uma concisa Memória dos fatos e diplomas desde 1792, em que realmente começou o Governo Real, como Príncipe Regente, não tenha o caráter de História, que deve ser a Mestra da Vida, contudo, pelas notórias circunstâncias, e ser menos interessante uma narrativa demasiadamente singela, bem que de si mesma digna de atenção pela matéria, faço observações históricas e econômicas, para mostrar a grandeza dos Benefícios Soberanos desde esse tempo, e afervorar os espíritos dos compatriotas, afim de fazerem cordiais e perenes votos de ser longo e próspero o reinado de El-Rei Nosso Senhor. ${ }^{95}$

\footnotetext{
${ }^{93}$ HARTOG, F. Tempo, História e a Escrita da História: A Ordem do Tempo, p. 11 a 14.

${ }^{94}$ ARAÚJO, V. L. de. A experiência do tempo: modernidade e historicização no Império do Brasil (1813-1845), p. 20. Reinhart Koselleck ressalta o papel da Revolução Francesa como marco divisório que estabelece uma nova forma de relacionamento com o tempo orientado não mais pelo passado, mas para o futuro (KOSELLECK, R. Historia Magistra Vitae - sobre a dissolução do topos na história moderna em movimento, p. 41 a 60).

${ }^{95}$ LISBOA, op. cit., p. V. Explica Maria Beatriz Nizza da Silva que, segundo o pensamento da época, estabelecia-se uma diferenciação entre memória e história, em termos narrativos. A História era entendida como uma construção demasiado monumental e ambiciosa, sendo lugarcomum entre aqueles que então registravam os fatos históricos dizer que apenas escreviam memórias, que serviriam como uma espécie de andaime para a elaboração da História, circunscrevendo-se à coleta e reunião de documentação, que permaneceria tal como foi coligida, sem passar por qualquer processo de interpretação ou de análise. SILVA, M. B. N. da. Cultura e Sociedade no Rio de Janeiro (1808-1821), p. 192 a 196.
} 
Como explica Manoel Salgado Guimarães, nessa forma de conceber a História sobressai a ideia que tornaria o conhecimento do passado útil pelo que poderia fornecer de ensinamentos para o presente: "um bom conhecimento da história (...) poderia auxiliar nesse processo de construir referências para a ação num mundo em transformação, marcado pela velocidade com que, uma a uma, as certezas do passado são postas em xeque". ${ }^{96}$ A História serviria, dessa forma, como estímulo à emulação, desempenhando o papel de uma mestra que ensina, mas também julga, "premiando ou punindo, segundo a ação dos homens mais ou menos de acordo com a verdade extraída do conhecimento do passado". ${ }^{97}$ Por isso, naquela forma de se relacionar com a História haveria, segundo esse autor, uma indissociação entre História e política, uma vez que o exercício da segunda demandaria o conhecimento adequado da primeira. A História poderia, dessa forma, servir como remédio contra o sentimento de vertigem gerado pelo conjunto de transformações em curso na virada do século XVIII para o XIX, "indicando no passado os portos seguros, as certezas que se poderiam contrapor às incertezas do presente": ${ }^{98}$ Dessa forma, o memorialismo histórico e suas re-presentificações do passado recente de Portugal pareciam adquirir um papel central na conjuntura de incertezas geradas pela guerra contra os franceses.

Por outro lado, ao analisar os artigos classificados sob a rubrica História no periódico O Patriota, Manoel Salgado identifica na forma como a História era apropriada pelos letrados portugueses do início do século XIX, ecos da filosofia da história que, em sua missão de tornar o passado digno da reflexão nacional, constituindo aquilo que parecia disperso num todo organizado e dotado de coerência, transformava o passado em etapa do próprio presente, transformado em futuro daquele passado: "Por esse movimento o sentido maior das ações humanas

\footnotetext{
${ }^{96}$ GUIMARÃES, M. L. S. As luzes para o Império: História e Progresso nas páginas de O Patriota, p. 77.

${ }^{97}$ Ibid., p. 78.

${ }^{98}$ Ibid., p. 70. "Estamos, assim, diante de uma perspectiva em que a história antes de tudo ilustra os leitores que aprendem com ela; os governantes que podem por meio dela afirmar o seu poder e a sua glória. A história inscreve-se por isso num conjunto amplo de iniciativas do Estado moderno, que para afirmar seu poder deve agora recorrer prioritariamente à força da pena e não mais das armas". Ibid., p. 69/70.
} 
parece ganhar significado. $\mathrm{O}$ passado se desvela pelas luzes que o presente lança sobre ele". 99

Dessa forma, apesar de apontarem para concepções distintas de tempo, uma circular e outra linear, podem ser identificados nas re-presentificações da transferência da corte publicadas pela Impressão Régia do Rio de Janeiro ecos tanto da concepção da historia magistra vitae, como da filosofia da história. Nas narrativas que justificavam a decisão tomada pelo Príncipe Regente elogiando-a, circularidade e linearidade se uniam em interpretações do processo histórico do Império português marcadas fundamentalmente pela ideia de continuidade. Sendo excluídos dessas narrativas quaisquer exemplos de rupturas traumáticas entre passado, presente e futuro. Entre as quais se incluía o próprio processo de transferência da corte. Atingindo um ápice nesse sentido a narrativa construída por José da Silva Lisboa na sua Memória dos Benefícios Políticos, onde, ao mesmo tempo em que lança mão de exemplos retirados do passado glorioso da monarquia portuguesa como forma de justificar as ações do presente (ou de um passado recente), o autor aborda a regência de D. João como a continuação de um processo que tem um ponto alto (e não uma ruptura) na transferência para a América, mas que se estende até 1818, sendo a sua conclusão a Aclamação de D. João como rei de Portugal, Brasil e Algarves.

\section{2.}

\section{“Proteção à Francesa"}

Entre novembro de 1807 e agosto de 1808, o General Jean-Andoche Junot governou Portugal enfrentando a oposição do grande número de panfletos políticos que, na intenção de exortar os portugueses à resistência, comentavam os

\footnotetext{
${ }^{99}$ GUIMARÃES, op. cit., p. 77. Na sua investigação sobre o moderno conceito de História, a filósofa alemã Hannah Arendt explica que o conceito moderno de história, cunhado ao longo do último terço do século XVIII, ao privilegiar a idéia de processo sobre a análise dos fatos por si mesmos, abriu espaço ao surgimento das teleologias que, se por um lado, afirmavam que o verdadeiro sentido dos fatos escapava aos seus autores, sendo revelado apenas às gerações futuras, quando o processo chegasse ao seu término (Kant, Hegel); por outro lado, iria confundir o sentido atribuído a posteriori aos fatos com a própria intenção dos atores históricos, transformando-os em fins intencionais de ação política (Marx). Como afirma a autora, o perigo de transformar os "desígnios superiores" desconhecidos e incognoscíveis em intenções planejadas e voluntárias estava em se transformar o sentido e a plenitude de sentido em fins. ARENDT, H. $O$ conceito de História-antigo e moderno, p. 110 a 121.
} 
principais acontecimentos da ocupação francesa, construindo a memória dos atos de Napoleão e dos generais do exército francês, por um lado, e dos feitos militares de resistência de portugueses, ingleses e espanhóis, por outro. Como afirma Iara Lis Schiavinatto, "Napoleão e D. João não se enfrentaram na arena aberta da guerra, mas no meio de uma vasta produção discursiva, onde se rivalizavam no âmbito dos atributos reais". 100 Tais publicações foram agrupadas e classificadas por Maria Beatriz Nizza da Silva como integrantes daquilo que ela denomina de Ciclo Napoleônico, assim definido pela autora:

Trata-se de obras e folhetos destinados a combater e denegrir o 'terrível corso', primeiro em Portugal e depois no Rio de Janeiro. O auge de tais publicações foi atingido nos anos de 1808 e 1809, mas o interesse prolongou-se até 1815 . (...) Muitos desses folhetos são diretamente contra Napoleão, outros contra os seus mais célebres generais, outros, finalmente, contra os franceses em geral. Poderíamos ainda considerar como complementos deste ciclo napoleônico as obras panegíricas dos chefes militares ingleses, espanhóis ou portugueses. ${ }^{101}$

Como explica Lúcia Bastos Pereira das Neves, esses panfletos políticos contribuíram para a construção de uma lenda negra de Napoleão: “Tais escritos possuíam uma certa pretensão histórica, cujo objetivo era assimilar ao imperador a imagem de um tirano cruel e degenerado, um homem indigno, a fim de se lhe atribuir, com verossimilhança, todos os tipos de crimes". ${ }^{102}$ Como ressaltado anteriormente, muitos desses panfletos políticos foram publicados também no Rio de Janeiro, onde certamente eram lidos como se contassem a versão oficial dos fatos ocorridos no Reino, juntamente com as notícias sobre a guerra publicadas na Gazeta do Rio de Janeiro, cuja abordagem não diferia em muito daquela realizada pelos panfletos. Em ambas as publicações os franceses eram representados como bárbaros que assolavam a Europa desde a Antiguidade. $\mathrm{O}$ que se observa, por exemplo, na narrativa de José Acúrsio das Neves:

Não foi somente em nossos dias que a França enviou enxames de seus habitantes para assolarem diferentes partes do mundo. Toda a Europa e grande parte da Ásia, da África e da América têm sentido em diversos tempos as depredações destes salteadores, que remontam às primeiras idades dos tempos históricos e têm sido

\footnotetext{
${ }^{100}$ SCHIAVINATTO, I. L. Entre historia e natureza: percepções do passado, p. 5.

${ }^{101}$ SILVA, M. B. N. da. Cultura e sociedade no Rio de Janeiro (1808-1821), p. 215. Informa a autora que um das características interessantes deste ciclo napoleônico foi a profunda repercussão que obteve junto às camadas populares, principalmente em Portugal. Ibid., p. 221.

102 NEVES, L. M. B. P. das. op. cit., p. 43. A autora classifica os panfletos políticos em quatro tipos: os antinapoleônicos, os antifranceses, os antiafrancesados e os exclusivamente patrióticos. Ibid., p. 45.
} 
marcadas com atrocidades horrorosas. ${ }^{103}$

Na memória dos acontecimentos construída por essas publicações, o plano de expansão de Napoleão é apresentado como conseqüência e continuação do processo revolucionário francês iniciado em 1789. Para Acúrsio das Neves, Bonaparte teria sido alçado ao poder pelos ensandecidos revolucionários, que viram nele a capacidade de restaurar a tranqüilidade pública na França e, ao mesmo tempo, dar continuidade à Revolução Francesa, pois, segundo Acúrsio a máxima que guiava a República francesa era "a da guerra eterna, até se revolucionar o continente". ${ }^{104}$ Mas Napoleão não deixava de ser, por isso, o Usurpador (sempre escrito em letra maiúscula, como se fosse um título) que teria se apossado do trono francês ilegitimamente:

Povos da Terra, contemplai os miseráveis restos da grande República Francesa, una, indivisível, que não durou dez anos! Vede como um pirata Corso, vomitado pelas ondas sobre as costas da França, depois de tantas vezes se julgar perdido, faz em um momento dobrar os joelhos a todos os invencíveis da Grande Nação, como dispõe da força pública, como entra nos Conselhos e sacode os venerandos dos seus assentos, como enfim os Brutos e os Catões da nova Roma recebem dele sossegadamente a lei! Faltavam-lhe ainda as honras do diadema, mas já tinha o poder e, desde então, devia prever-se que ele ousaria brevemente assentar-se, debaixo de títulos mais pomposos, sobre o trono de Henrique IV e de Luís XIV, e colocar sobre a sua cabeça a coroa de ferro dos antigos reis lombardos. ${ }^{105}$

Mas ele era igualmente o Usurpador de outros tronos europeus que, com a ligeireza das suas marchas, a arte dos acampamentos, a ordem das batalhas, a sorte que o seguia por toda a parte e "à força de ouro, de promessas e de enganos, intrigou os Ministérios e os Generais, tomou praças, conquistou reinos e roubou a Europa". ${ }^{106}$ Em particular o trono de Portugal, tomado a custa de traições aos tratados celebrados entre esse Reino e a França. Segundo Acúrsio, o titulo de Usurpador isentaria Bonaparte do dever de honrar tratados e respeitar convenções:

O justo, o moderado Bonaparte tem um título que o dispensa desta e de outras semelhantes práticas prescritas pelas leis fundamentais da sociedade, estabelecidas pela Natureza entre todas as Nações e consagradas pelo uso constante de todos os povos cultos: é o Usurpador Universal. ${ }^{107}$

\footnotetext{
${ }^{103}$ NEVES, J. A. das. O Despertador dos Soberanos e dos Povos, p. 3

${ }^{104}$ NEVES, J. A. das. Manifesto da razão contra as usurpações francesas, p. 12/13.

${ }^{105}$ Ibid., p. 12.

${ }^{106}$ Ibid., p. 14

${ }^{107}$ NEVES, J. A. das. Reflexões sobre a invasão dos franceses em Portugal, p. 23/24.
} 
Em suma, Napoleão seria pior do que os bárbaros germânicos que derrubaram o Império Romano ou os muçulmanos que invadiram a Península Ibérica:

Para se dar com usurpações tão manifestas como as dos Revolucionários da França, e do seu digno continuador Bonaparte, é necessário remontar aos povos do Norte que destruíram o Império Romano, ou aos Sarracenos que sucederam a estes bárbaros. Mas se olhamos com imparcialidade para as declamações que nos restam dos escritores daquele tempo, apesar de muito exageradas, como uma boa crítica faz conhecer, vemos sim que se imputam àqueles conquistadores as profanações, os roubos, e todo o gênero de crimes que sempre costumam acompanhar estas irrupções. Mas não as falsidades, os enganos e as baixezas de que temos sido testemunhas. Átila e Genserico eram homens de bem em comparação de Bonaparte e de seus infames sequazes; que se têm praticado algumas ações ilustres, estão sepultadas debaixo do monte imenso dos seus atentados. ${ }^{108}$

O autor das já citadas Reflexões sobre a conduta do Príncipe Regente de Portugal, apesar de discordar de Acúrsio das Neves com relação à transferência da corte para a América, como já vimos; parece concordar integralmente com essa representação de Bonaparte. Também na sua narrativa, Bonaparte é representado como o bárbaro continuador da Revolução Francesa, elevado ao trono com a obrigação de disseminar a revolução por todo o continente europeu:

Então apareceu Bonaparte; ele não fez a revolução, mas a revolução foi quem o fez; ele não a principiou, mas foi a consequiência dela. Ela o domina e pode destruilo se ele cessasse um momento de ser o flagelo do mundo e se, contente da sua fortuna, quisesse hoje descansar e gozar dela. O espírito infernal inspirou a escolha que se fez dele, porque as obrigações que lhe impuseram foram próprias e conseqüientes com as suas inclinações, criaram-no para destruir, para assolar, para verter sangue, para despojar e cobrir a Europa de crimes e de lágrimas; e as obrigações que lhe impunham eram deleites e gostos para a alma mais atroz, mais pérfida e mais cruel que jamais abismou o Universo. ${ }^{109}$

Tendo por missão disseminar a revolução, Napoleão é representado pelos panfletários como o inimigo do comércio e das Luzes, pois por toda parte onde chegavam os seus exércitos, desaparecia a agricultura e a indústria, a navegação e o comércio marítimo porque os braços necessários ao seu funcionamento eram drenados para a guerra. Ele seria, ainda segundo Acúrsio, o inimigo natural dos homens de letras, a quem temia porque não ignorava que as letras eram inimigas do despotismo, e as Luzes lhe eram mais funestas do que os exércitos:

\footnotetext{
${ }^{108}$ Ibid., p. $3 / 4$.

${ }^{109}$ FRANCO, op. cit., 4/5.
} 
Deixai radicar o Tirano no seu sistema de usurpação universal, vereis como tudo se encaminha a renovar na Europa a estupidez dos tempos bárbaros, debaixo de um déspota que, roubando por vaidade as bibliotecas e os gabinetes em que tem podido meter a mão, para engrandecer com os despojos do Mundo a capital da França, a que atrevidamente já chamaram Capital da Europa, desejaria no fundo do seu coração poder aquentar as fornalhas de Paris com todos os livros da terra, e destruir até as sementes da literatura, para firmar e perpetuar um tal sistema que só na ignorância pode sustentar-se. ${ }^{110}$

Acúrsio exorta os homens de letras a utilizarem o seu talento na resistência contra Napoleão, atribuindo à imprensa um papel fundamental naquela conjuntura política, pelo seu alcance, disseminando as notícias sobre as atrocidades cometidas pelos franceses e incentivando os povos à resistência. Em suma, aquilo que ele próprio procurava fazer por meio dos seus panfletos:

Homens de letras do presente século, que tendes feito elevar tão alto a voz da humanidade contra os verdugos que a oprimem; que tanto tendes clamado com os direitos e os deveres do cidadão, com o amor da Pátria e da verdadeira glória! (...) Onde está o vosso amor da Pátria, qual é a vossa verdadeira glória se não usais da superioridade que as vossas luzes vos concedem sobre o resto dos homens, para atacar os opressores da humanidade e salvar os vossos concidadãos das desgraças da tirania? ${ }^{111}$

Essa representação negativa de Napoleão contrasta com os elogios que encontramos nesses panfletos ao rei e marechais britânicos e, como não podia deixar de ser, ao monarca português. Nos seus panfletos, Acúrsio das Neves não poupa elogios ao rei e ao exército britânico, contrastando nitidamente, não podemos deixar de notar, com as críticas a essa nação que encontramos nas suas obras de economia política, escritas poucos anos mais tarde, mas já em outra conjuntura política. Na sua narrativa a monarquia britânica é representada, como heroína da resistência à Bonaparte e bastião da liberdade européia:

E que seria, então, do mundo inteiro se a Inglaterra, este fortíssimo baluarte da liberdade da Europa não sustentasse ainda a sua independência, para reivindicar um dia a das outras nações? Generosa Nação Britânica! Os tiranos conjuraram contra ti o continente. Esse mesmo, de que és o firmíssimo apoio. Cuidaram arrancar-te os olhos, excluindo os teus navios de todos os portos da Europa, declarando guerra ao teu comércio e às tuas manufaturas, roubando-te quanto puderam, e declarando-te (...) bloqueado por mar e por terra. Mas primeiro perderam eles a vista. (...) Nação heróica! A Providência te rodeou do teu elemento, para te salvar da tirania do Usurpador. A Providência tem prolongado a tua existência e aumentado o teu poder, para restabeleceres tantos governos abatidos, enxugares as lágrimas a tantos

\footnotetext{
${ }^{110}$ NEVES, J. A. das. O Despertador dos Soberanos e dos Povos, p. 28.

${ }^{111}$ Ibid., p. 26.
} 
povos assolados. ${ }^{112}$

Procurando manter as aparências dos acordos diplomáticos estabelecidos entre Portugal e França durante as negociações ocorridas ao longo dos anos de 1806 e 1807, as tropas de Junot entraram em Portugal sob o pretexto de proteger o monarca português e o Reino contra os ingleses, que seriam os verdadeiros inimigos de Portugal, como faz questão de reafirmar o general francês na sua primeira proclamação aos habitantes de Lisboa:

Habitantes de Lisboa.

O meu exército vai entrar na vossa cidade. Eu vinha salvar o vosso porto e o vosso príncipe da influência maligna da Inglaterra. (...) Moradores de Lisboa, vivei sossegados em vossas casas; não receeis cousa alguma do meu Exército nem de mim; os nossos inimigos e os malvados devem temer-nos. O Grande Napoleão, meu Amo, envia-me para vos proteger, eu vos protegerei. ${ }^{113}$

Porém, apesar das ordens de D. João para que os franceses fossem recebidos como aliados, e das declarações de amizade de ambos os lados, os acontecimentos que se seguiram fariam desvanecer de todo a aparência de proteção. Por uma série de Decretos publicados ainda ao longo dos meses de dezembro de 1807 e janeiro de 1808, Junot procurou estender o seu controle sobre a população da capital: foram proibidos os ajuntamos nas praças e cafés; o porte de armas mesmo por caçadores; decretado o toque de recolher e o controle das atividades de pesca afim de evitar fugas ou a comunicação com a esquadra inglesa que se encontrava ancorada fora da barra, bloqueando o porto de Lisboa; e confiscadas todas as propriedades inglesas em Portugal. Acúrsio das Neves, no seu Manifesto da razão contra as usurpações francesas, publicado ainda em 1808 em Portugal, já denunciava a farsa da proteção à francesa exortando os portugueses à resistência:

A raiva do grande Usurpador e dos tiranos subalternos, despregou-se (...) com toda a fúria sobre o triste Portugal, e sempre com a pérfida máscara da proteção. Vinham proteger o Soberano de Portugal contra os roubados e proscritos ingleses,

\footnotetext{
${ }^{112}$ NEVES, J. A. das. Manifesto da razão contra as usurpações francesas, p. 17. O autor chega ao ponto de escrever um panfleto intitulado A Generosidade de George III e a ambição de Bonaparte: Wellesley e os generais franceses, cuja motivação principal era comparar a atitude "desinteressada" dos ingleses na defesa da Europa com a ambição desmedida do Usurpador: "Vede, de uma parte, a generosidade do imortal Jorge e da nação inglesa, prodigando o seu ouro e expondo as suas tropas para restituírem a liberdade à Europa; da outra, a ambição desmedida do Usurpador, que unindo as máximas do mais atroz despotismo aos princípios revolucionários que aprendeu nos clubs jacobinos, tem feito do continente um campo de destruição" (NEVES, J. A. A Generosidade de George III e a ambição de Bonaparte: Wellesley e os generais franceses, p. 21).

${ }^{113}$ Correio Braziliense, $\mathrm{n}^{\circ} 1$, junho de 1808 , p. 8.
} 
e como o soberano não lhes aceitou a proteção, declararam-se os protetores dos vassalos. Portugueses! Todo aquele que vos quiser proteger contra vossa vontade, é um traidor que vos arma o laço para vos encadear. Vós ides conhecê-lo pelos fatos. $^{114}$

D. José Caetano da Silva Coutinho, por sua vez, afirma na sua já citada Memória Histórica da Invasão dos Franceses em Portugal no ano de 1807 que nos primeiros meses de ocupação não se desacreditava ainda, ao menos publicamente, da idéia de proteção e de amizade que tão altamente se tinha proclamado em nome de Napoleão. Porém, essa confiança foi pouco a pouco se desvanecendo. Principalmente após os Editais de primeiro de fevereiro de 1808, que decretavam, entre outras coisas, nada mais nada menos do que a destituição da Casa de Bragança e do Conselho de Regência instituído por D. João. Esse documento mereceu especial atenção por parte de Silva Coutinho. Este último escreve um capítulo inflamado onde repete as representações de Napoleão como bárbaro usurpador que, ao destituir o monarca português, desrespeitou não só os seus direitos ao trono, mas a própria história do Império Português, referindo-se ao episódio da Restauração de 1640 que levou ao trono a dinastia de Bragança, e reatando o passado, presente e futuro da monarquia portuguesa em uma linha de continuidade, cuja ruptura era de responsabilidade dos exércitos franceses:

\begin{abstract}
Nunca, pelas leis fundamentais de nenhum Estado da Europa, e muito menos pelas de Portugal, foi vedado a um príncipe sair dos seus Estados por interesse do mesmo Estado ou da Sua Real Pessoa. (...) Quem deu a um corso baixo e vil a autoridade e o direito de tomar contas de sua conduta a um príncipe soberano e independente? Se os portugueses se não lembram do crime de emigração, que nunca existiu, se respeitam, se amam e adoram o herdeiro de uma Casa que eles mesmos chamaram para o trono, que levantaram com tanto sangue e ações de tanta glória, se eles não querem e não podem conhecer outro monarca, qual a razão porque este corso atrevido despreza este monarca e despreza a nação inteira, para se ingerir ele mesmo a dominar como escravos uns povos livres que o aborrecem? (...) Quando os portugueses não tivessem um herdeiro legítimo da Casa Real que os governasse, quando, por impossível, não achassem um português benemérito que fizessem montar sobre o trono, eles iriam buscar para seu rei um turco e um argelino antes do que o fero Monstro da Córsega, que não tem religião nem piedade, nem humanidade, nem justiça, nem ciência, mas só impostura e atrevimento. ${ }^{115}$
\end{abstract}

José Acúrsio das Neves reproduz o decreto de primeiro de fevereiro, que ele denomina de Edital da destruição do nosso Governo e das promessas da nossa

\footnotetext{
${ }^{114}$ NEVES, J. A. das. Manifesto da razão contra as usurpações francesas, p. 21/22.

115 COUTINHO, J. C. da S. Memória Histórica da Invasão dos francezes em Portugal no ano de 1807, p. 61 a 63.
} 
felicidade, interpolando-o com comentários. No principal parágrafo desse Edital, afirma Junot que "O Príncipe do Brasil, abandonando Portugal, renunciou a todos os seus direitos à soberania deste Reino. A Casa de Bragança acabou de reinar em Portugal." 116 Ao que questionava Acúrsio, mencionando os termos do Edital de D. João de 26 de novembro de 1807, em parágrafo que guarda muitas semelhanças com o texto de Silva Coutinho:

O Decreto de 26 de Novembro de 1807 é bem terminante a este respeito: S.A.R., saindo da sua capital para uma outra cidade dos seus Estados, para fugir aos assassinos, e poupar o sangue dos seus vassalos, deixa um Conselho de Regência e lhe prescreve a forma porque à de governar o Reino. É isto renunciar à Soberania? E suponhamos que a tinha renunciado [sic], quem deu autoridade a Bonaparte para se intrometer a governar-nos contra nossa vontade? ${ }^{117}$

As promessas de felicidade a que alude Acúrsio, por sua vez, ficavam por conta do trecho do Edital de Junot em que afirmava que a "deforme mendicidade não arrastará mais os seus fatos imundos na soberba capital, nem pelo interior do Reino". ${ }^{118}$ Segundo Acúrsio, esta afirmação era "um dos maiores descaramentos possíveis", pois não se via em Lisboa senão pessoas de todas as classes mendigando o sustento pelas ruas e pelas casas. E se assim não fizessem, "se não veriam senão ladrões, por serem imensas as pessoas que a invasão francesa reduziu à última miséria". ${ }^{119}$ Efeito da estagnação do comércio e da indústria provocados pela invasão do Reino pelos franceses. Afirma esse autor, talvez com algum exagero, que

a metade dos habitantes de Lisboa, reduzidos à última miséria, vagavam aos montes, mendigando as escassas esmolas daqueles entes benfeitores a quem a Providência quis conservar alguns restos das suas fortunas, para consolação de tantos desgraçados. ${ }^{120}$

Também Silva Coutinho alude à situação de miséria em Lisboa por ocasião da ocupação da cidade pelas tropas de Junot, afirmando que para escapar à calamidade, milhares de pessoas tinham se refugiado para as províncias e para fora do Reino, e que até os próprios franceses residentes em Lisboa estavam se retirando da cidade. O Bispo memorialista repete a cifra levantada por Acúrsio

\footnotetext{
${ }^{116}$ Correio Braziliense, n³, agosto de 1808, p. 164.

${ }^{117}$ NEVES, J. A. das. Reflexões sobre a invasão dos franceses em Portugal, p. 43/44.

${ }^{118}$ Correio Braziliense, $\mathrm{n}^{\circ}$ 3, agosto de 1808, p. 165.

119 NEVES, J. A. das. Reflexões sobre a invasão dos franceses em Portugal, p. 48/49.

${ }^{120}$ NEVES, J. A. das. Manifesto da razão contra as usurpações francesas, p. 31.
} 
afirmando que "mais da metade de seus habitantes pede esmola ou, a quem lha não pode dar ou a quem tem dinheiro mas quer fazer figura de pobre para escapar à rapacidade do governo". ${ }^{121}$

O fato é que tais promessas contrastavam com a instituição de pesadas contribuições compulsórias, decretadas em dois editais publicados alguns dias depois. A Gazeta de Lisboa de 9 de fevereiro de 1808 publicou um Edital assinado pelo próprio Napoleão Bonaparte e datado de 23 de dezembro do ano anterior, que foi afixado pelas ruas de Lisboa. Esse documento instituía uma contribuição extraordinária de guerra no valor de 100 milhões de francos, "a titulo de resgate de todas as propriedades, debaixo de quaisquer denominações que possam ser, pertencentes a particulares", além de decretar o seqüestro de todos os bens da Família Real e dos nobres que acompanharam o Príncipe Regente. ${ }^{122}$ A respeito desse decreto, afirma o Bispo José Caetano da Silva Coutinho que Napoleão se serviu do título de resgate apenas para encobrir um crime por meio de outro ainda mais horroroso:

Queria fazer um grande roubo em Portugal e, para isso, foi necessário supor os portugueses despojados de todos os seus bens, concedendo-lhes a graça e o favor de resgatá-los pela sobredita soma de 40 milhões, achando deste modo o método de cometer as mais atrozes injúrias debaixo das aparências de quem faz benefícios, e ajuntando em um só caráter a desumanidade de um ladrão com a vaidade de um benfeitor. ${ }^{123}$

Também Acúrsio das Neves comenta o decreto, que intitula de Edital da subversão das nossas fortunas, se perguntando como era possível cobrar uma contribuição de guerra de um país que se proclamava aliado, chamando a atenção mais uma vez para a farsa da proteção à francesa:

O General em Chefe do Exército Francês veio proclamando desde Alcântara que marchava em socorro de S.A.R. contra os ingleses; quando chegou a Lisboa, proclamou que vinha proteger os portugueses de mandá-lo seu amo, e que ele os protegeria; como Protetor e aliado foi ele recebido com o seu mesmo exército; não se disparou um tiro sobre a sua tropa, nem encontrou ato algum de resistência para se apossar do Reino; o mesmo Napoleão nos fez dizer, pela carta da nossa chamada deputação de 27 de abril de 1808, que não olhava Portugal como um país conquistado. Haja, pois, quem me concilie estas idéias com a de uma contribuição de guerra para resgate de todas as propriedades. ${ }^{124}$

\footnotetext{
${ }^{121}$ COUTINHO, op. cit., p. 16

${ }^{122}$ Correio Braziliense, $\mathrm{n}^{\mathrm{o}}$ 3, agosto de 1808, p. 169/170.

${ }^{123}$ COUTINHO, op. cit., p. 71.

${ }^{124}$ NEVES, J. A. das. Reflexões sobre a invasão dos franceses em Portugal, p. 51/52.
} 
Em complemento ao Edital de 9 de fevereiro, Junot mandou afixar outro em que estabelecia outra contribuição extraordinária de 40 milhões de cruzados e o confisco de todo o ouro e prata de todas as igrejas, capelas e confrarias da Cidade de Lisboa e seu termo. ${ }^{125}$ Segundo Acúrsio, tais contribuições obrigatórias, assim como o sequestro dos bens da nobreza e da Igreja, serviram para vestir e nutrir o exército protetor de Junot que quando entrou em Lisboa apresentava "soldados rotos, macilentos e descarnados, que pareciam espectros fugidos aos túmulos"; ${ }^{126}$ e complementavam o plano de usurpação do trono português, que Acúrsio resume da seguinte forma:

Tratou-se como emigrado um soberano que não fez mais do que sair da capital do seu Reino para uma outra cidade dos seus domínios com o fim de salvar a sua vida, e poupar o sangue dos seus vassalos, em uma resistência que seria tão indiscreta como inútil. Foram-lhe profanados e roubados os seus palácios, as suas berlindas, os seus coches, todos os seus móveis e preciosidades sobre que se pode lançar a mão, foram-lhe dissipados e devastados os seus bens patrimoniais e os da Coroa. E por quem? Por aqueles mesmos que diziam vir como auxiliares, e que este mesmo Príncipe acabava de mandar receber como tais, ordenando aos seus vassalos que lhes dessem o melhor acolhimento, e os tratassem como os aliados mais favorecidos. ${ }^{127}$

Acúrsio, e outros panfletários, chamam a atenção para o fato de que essa mesma espécie de proteção se estendeu aos bens dos nobres que acompanharam o Príncipe Regente, em particular, e com toda a população de Lisboa, em geral:
Iguais cenas de roubos e de dilapidações, paliadas com o nome de seqüestros, se praticaram nas casas e nos bens dos vassalos fiéis que acompanharam o soberano, dos oficiais da sua casa e dos seus conselheiros, que além de emigrados foram tratados de pérfidos. (...) Não foi menos dura a proteção dos particulares, daqueles cidadãos tranquilos que não puderam fugir à escravidão, dos honrados habitantes de Lisboa aos quais tanto se clamava que estivessem sossegados nas suas casas porque nada tinham que temer, e tantas felicidades se prometiam. $O$ Grande Napoleão, meu Amo, dizia o General em Chefe no seu manifesto, me envia para vos proteger, eu vos protegerei. ${ }^{128}$

\footnotetext{
${ }^{125}$ Apesar de também ser datado de primeiro de fevereiro tudo indica que esse Edital não foi divulgado no mesmo dia. Afirma Acúrsio que "Demoraram os nossos bárbaros protetores por dois, ou três dias a publicação deste Edital, ou porque se envergonharam de o patentear no mesmo dia em que publicaram o outro, em que tantas felicidades se nos prometiam, ou mais depressa, porque temeram provocar o ressentimento de uma nação espirituosa e intrépida, posto que desarmada e maniatada, intimando-lhe em um só dia os terríveis Decretos que deviam despojar-nos do nosso Governo e dos nossos cabedais" (Ibid., p. 65). Silva Coutinho data esse Edital de quatro de fevereiro.

${ }^{126}$ NEVES, J. A. das. Manifesto da razão contra as usurpações francesas, p. 26.

${ }^{127}$ Ibid., p. 22.

${ }^{128}$ Ibid., p. 23 a 26.
} 
Segundo a narrativa de Silva Coutinho, porém, a medida que parece ter causado maior comoção na população da capital foi o decreto de sequestro de todos os bens pertencentes à Casa Real:

Contra ninguém se manifesta tanto o furor da rapina como contra tudo aquilo que pode ter o nome ou título da Casa Real Portuguesa. É quase impossível que o coração mais duro ou mais frio não faça correr lágrimas pelos olhos que a cada passo observam nas ruas de Lisboa as carruagens, os criados, as librés e todas as coisas pertencentes aos nossos amáveis soberanos convertidas no serviço e no prazer de quatro forasteiros que, sabendo-se de seus obscuros princípios, aspira cada um por seu modo à grandeza e pompa Real e afeta todas as maneiras da Majestade com que pretendem oprimir os desvalidos portugueses. ${ }^{129}$

A determinação de sequestro dos bens da Igreja deu margens a considerações sobre o desrespeito dos franceses com a religião católica que eles diziam professar e prometiam proteger e socorrer no Edital de primeiro de fevereiro: "A religião de vossos pais, a mesma que todos professamos, será protegida e socorrida pela mesma vontade que soube restaurá-la no vasto Império francês, mas livre das superstições que a desonram". ${ }^{130}$ Aqui também a proteção se transformava em usurpação, na narrativa de Acúrsio:

Esta mesma religião e seus ministros, estes mesmos templos viram bem depressa sobre si a proteção do Usurpador: baixaram ordens para todos serem despojados da maior parte das suas rendas, e as igrejas da sua prata e ouro. Ordens tão bem executadas que, em breve tempo, por toda a extensão do Reino, se viram despojados os templos de todas as preciosidades com que a magnificência dos soberanos, e a piedade dos fiéis, os tinham enriquecido por mais de setecentos anos. A estes ajuntou uma soldadesca desenfreada os ultrajes, os escândalos mais sacrílegos. Templos se converteram em quartéis, até dentro da própria Capital; alguns houve de que se fizeram estrebarias; arrastaram-se e queimaram-se as imagens sagradas; profanaram-se as Santas Aras e até os vasos e as partículas Sacro-santas; praticaram-se todas as execrações que traz consigo a irreligião e a libertinagem. ${ }^{131}$

O desrespeito com a religião católica por parte dos franceses é ressaltado também, como não poderia deixar de ser, pelo Bispo Silva Coutinho. Desrespeito que começa antes do sequestro dos bens da Igreja, com o estabelecimento das tropas francesas nos templos da capital:

Os regimentos franceses se acham aquartelados nos Conventos de S. Francisco da

\footnotetext{
${ }^{129}$ COUTINHO, op. cit., p. 14.

${ }^{130}$ Correio Braziliense, $\mathrm{n}^{\circ} 3$, agosto de 1808, p. 164.

${ }^{131}$ NEVES, J. A. das. Manifesto da razão contra as usurpações francesas, p. 24/25.
} 
Cidade, de Domingos, dos Paulistas, de Jesus, dos Camilos, dos Gracianos e de S. Vicente, e em todos aqueles em que acharam alguma capacidade, não escapando até as igrejas ou capelas, cujos santos e altares se viram, por alguns dias, servir de cabide às armas e mochilas dos soldados. ${ }^{132}$

Enquanto os cronistas e panfletários portugueses replicavam às promessas de prosperidade contidas nas proclamações francesas caracterizando-os como usurpadores e ladrões, pois como afirmava Acúrsio da Neves, "na arte de furtar ninguém excede a esses generosos protetores da Europa"; ${ }^{133}$ a população de Lisboa reagia com ironia à auto-proclamação dos franceses como protetores de Portugal, contida nos seus Editais. Contava o Bispo Silva Coutinho que diante de tantos Decretos que determinavam a mais completa espoliação do Reino ninguém mais acreditava na beneficência e na proteção francesa:

As suas palavras e promessas passam hoje em provérbio ainda mais ignominioso do que a fé púnica entre os romanos; de tal maneira que hoje, em Lisboa, um arrieiro, um barqueiro, uma regateira, um rapaz mesmo de pouco anos, quando querem ameaçar alguém não dizem que hão de batê-lo, roubá-lo ou fazer-lhe qualquer espécie de mal, mas somente lhe dizem todos enfurecidos que hão de protegê-lo. Porque tudo isto significa hoje a proteção à francesa. ${ }^{134}$

A "proteção à francesa" se transformou de tal modo em piada em Portugal a ponto de ter sido publicado em Lisboa ainda em 1808, e no Rio de Janeiro no ano seguinte, um panfleto intitulado justamente Proteção à Francesa, em que o autor anônimo reproduz em versos jocosos os mesmos acontecimentos do período de ocupação de Portugal por Junot e seu exército. ${ }^{135}$ Ao narrar a entrada dos exércitos franceses em território português, por exemplo, o autor repete a representação dos soldados rotos e esfomeados feita por Acúrsio das Neves:

Que vem a ser ter entrado

Dias antes do Natal

Tropa estranha em Portugal

Mal calçada e mal vestida,

Esfaimada e entorpecida

\footnotetext{
132 COUTINHO, op. cit., p. 9.

133 NEVES, J. A. das. Manifesto da razão contra as usurpações francesas, p. 27.

${ }^{134}$ COUTINHO, op. cit., p. 69.

135 Apesar de não constar o nome do autor no frontispício da publicação, de acordo com anúncio na Gazeta do Rio de Janeiro, a autoria da obra seria de José Daniel Rodrigues da Costa: "Saiu à luz a obra mui jocosa: Surriada a Massena em Portugal e encontro das duas rivais no Palácio Imperial de França, por José Daniel Rodrigues da Costa. Vende-se na loja da Gazeta a 320 réis, onde se acha, do mesmo autor, Proteção à Francesa, por 320 réis, e o Embarque dos apaixonados dos Franceses, por 320 réis". Gazeta Extraordinária do Rio de Janeiro, nº 11, 18 de junho de 1811.
} 
De cansaço ou de fraqueza?

É proteção à francesa.

O autor dos versos satíricos se refere também à destituição da monarquia de Bragança por Junot, que consumou a usurpação do trono português:

Que vieram cá fazer,

Sem lhes mandarmos recado?

Comerem-nos pão e gado,

Pondo tudo em confusão!

Desta gente a proteção

Tem diversa natureza

É proteção à francesa.

Condenar como emigrado,

Quem foi para o que era seu,

E que nenhum poder deu

A bárbaros protetores!

Isto, meus ricos senhores,

É cobiça muito acesa,

É proteção à francesa.

As cenas de desrespeito com a religião católica por parte das tropas francesas também é reproduzida pelo poeta anônimo:

Dizerem que são cristãos,

Sendo na Lei mascarados,

Roubar os vasos sagrados

Com sacrilégio tremendo,

$\mathrm{Na}$ igreja bestas metendo;

Este insulto, esta baixeza

É proteção à francesa.

Por vingança ir aos conventos

E com rancor, sem piedade

Matar o clérigo e o frade,

As freiras ir perseguir,

Fazer os povos fugir,

E nos seus bens fazer presa!

É proteção à francesa.

O autor conclui o poema com a comparação dos franceses com bárbaros, desfavorável aos primeiros:

Se os mouros aqui tornassem,

Outro tanto não fariam.

Se os franceses protegiam

Os mais Reinos desta sorte,

Já sabem que o saque, a morte,

A fome, o engano, a fereza, 


$$
\text { É proteção à francesa. }{ }^{136}
$$

$\mathrm{Na}$ divulgação das notícias sobre a guerra na Europa feita pela Gazeta do Rio de Janeiro é possível encontrar uma representação semelhante de Napoleão e dos exércitos franceses a que vemos nos panfletos políticos. Tais notícias, que deviam ser muito ansiadas pela população do Rio de Janeiro, principalmente por aqueles recém-emigrados que haviam deixado em Portugal familiares e pertences, ocupavam a quase totalidade das quatro páginas do periódico entre 1808 e 1816. Era tamanho o volume de notícias publicadas a esse respeito que chegavam, por vezes, a ocupar edições inteiras do jornal, demandando também a publicação de edições extraordinárias que complementassem as notícias. Tereza Maria Fachada Levy Cardoso divide cronologicamente a publicação da Gazeta do Rio de Janeiro em duas fases: a primeira de 1808 a 1816 e a segunda de 1817 a 1821 . Enquanto na primeira fase predominariam as notícias sobre a guerra na Europa, na segunda o periódico passaria a reservar mais espaço para as notícias do Brasil. Segundo quadro estatístico elaborado por ela, entre 1808 e 1816 foi publicada uma média anual de 17 Gazetas Extraordinárias, enquanto que no período entre 1817 e 1820, essa média cai para 6 números extraordinários. $O$ número de edições extraordinárias só volta a subir no turbulento ano de 1821, quando foram publicadas 23 Gazetas Extraordinárias do Rio de Janeiro. ${ }^{137}$

É preciso chamar a atenção para duas características importantes das publicações das notícias sobre a guerra no periódico. A primeira delas é o fato de que, assim como na Gazeta de Lisboa, as informações sobre a situação européia publicadas na Gazeta do Rio de Janeiro eram retiradas de periódicos europeus de várias procedências. Nesse caso, principalmente periódicos ingleses e portugueses. Como era de se esperar, apenas as notícias oriundas de periódicos franceses eram sistematicamente colocadas em dúvida, e publicadas na Gazeta de preferência quando noticiavam algum revés do exército ou da diplomacia francesa, mas sempre comentadas pelo redator do periódico. Cartas particulares de militares e políticos de relevância no período, ou mesmo cedidas pelos leitores, também eram publicadas quando traziam alguma notícia de interesse que não

\footnotetext{
${ }^{136}$ ANÔNIMO. Proteção à Francesa, p. 1 a 10.

${ }^{137}$ CARDOSO, T. M. F. L. A Gazeta do Rio de Janeiro: subsídios para a história da cidade (1808-1821), p. 388 a 396
} 
constasse da imprensa estrangeira, quando corroboravam alguma notícia já publicada pela Gazeta ou mesmo quando havia falta de notícias decorrente de algum atraso na entrega dos jornais europeus. Mesmo tais fontes, por mais subjetivas que fossem pela sua própria natureza, mereciam mais crédito do que as notícias publicadas em periódicos franceses. Somente a partir de 1815 os periódicos franceses passaram a gozar da mesma credibilidade dos periódicos ingleses e a fazer parte das fontes utilizadas pelo redator da Gazeta sem ressalvas. Na edição de 19 de outubro de 1808, o redator da Gazeta faz uma comparação entre os periódicos ingleses e franceses com relação à sua credibilidade:

As Gazetas, que em Inglaterra são constitucionalmente livres e singelas, vêm a ser em França um dos meios essenciais de que o governo lança mão para se acreditar persuadindo o que quer. É, portanto, necessário ler com suma prevenção tudo quanto são papéis franceses. Quero dizer, todos os dos diferentes países onde existe influência francesa, pois de certo contêm falsidades, e muitas vezes tão descaradas que admira como se atrevem a publicá-las, se não se soubesse que um dos caracteres do despotismo é o desprezo até à verossimilhança. ${ }^{138}$

A segunda característica para a qual é necessário atentar é o fato de que, como explica Juliana Gesuelli Meirelles, apesar de não assinadas, as falas do redator eram eminentemente opinativas e podiam ser encontradas nas notícias que traziam no cabeçalho "Rio de Janeiro" e a data do dia da publicação. Era prática comum à época, também, intercalar a publicação de documentos e notícias com comentários escritos pelo redator do periódico. Tal como fazia Acúrsio das Neves em seus panfletos políticos, reproduzindo e comentando os Editais de Junot. O que torna a linguagem utilizada nos periódicos muito parecida com a narrativa encontrada nos panfletos políticos publicados no mesmo período. Um exemplo interessante dessa prática pode ser encontrado na edição de primeiro de outubro de 1808, onde é copiada uma proclamação de Junot aos habitantes das províncias de Entre Douro e Minho, então sublevadas contra a presença francesa, intercalada com comentários escritos pelo redator do periódico de onde se copiou a proclamação, a Minerva Lusitana, destacados em itálico para diferenciar-se do

${ }^{138}$ Gazeta do Rio de Janeiro, $\mathrm{n}^{\circ}$ 11, 19 de outubro de 1808. A edição de 22 de julho de 1809 publica dois boletins franceses acerca da guerra com a Áustria, porém, com a devida advertência do redator: "Apresentamos ao público os dois boletins publicados pelo inimigo da independência da Europa e do mundo todo, e sentimos grandemente não estarmos inteirados destes acontecimentos senão pelos seus papéis, em que de certo há demasiada exageração. (...) parece que os franceses chamam batalhas a pequenos combates, e derrota a uma retirada que o arquiduque Carlos fez para concentrar o seu exército". Gazeta do Rio de Janeiro, nº 90, 22 de julho de 1809. 
texto da Proclamação:

O Ilustríssimo e Excelentíssimo Senhor Duque de Abrantes, General em Chefe do Exército de Portugal, acaba de dirigir a proclamação seguinte aos habitantes de algumas partes das províncias de Entre Douro e Minho e dos Algarves. O General Junot não é Duque de Abrantes porque ainda semelhante título the não foi conferido pelo legítimo soberano deste Reino, de quem só o podia receber. (...) Os quais, deixando-se levar por conselhos pérfidos, se sublevaram. Nós não nos sublevamos. Pegamos em armas para defendermos os direitos do nosso legítimo soberano e da nossa pátria, oprimidos por usurpadores. Nem [ilegível] tivemos conselhos alguns para assim obrarmos. Fizemos o que devíamos de [ilegível] nossa própria deliberação. Sem calcular a impossibilidade de bom êxito durável de uma tão desatinada empresa. O próprio General Junot conhecerá brevemente se a empresa há de ter bom ou mau êxito. ${ }^{139}$

Segundo a síntese de Tereza Cardoso, da análise do conteúdo das notícias sobre a guerra publicadas no periódico "observamos que foram escritas em tom patriótico, valorizando e incentivando os portugueses em sua luta contra Napoleão". ${ }^{140} \mathrm{O}$ que era mais um ponto de aproximação entre a linguagem do periódico e a dos panfletos políticos. Ressaltavam, sobretudo, a marcha da restauração em Portugal e na Espanha, dando destaque para as derrotas das tropas napoleônicas, e publicavam diversas proclamações dos generais portugueses e dos governadores do Reino aos seus soldados e à população em geral. A primeira edição da Gazeta do Rio de Janeiro é quase completamente constituída por notícias sobre a guerra. A maior parte delas parece ter sido copiada de um periódico inglês e apresenta datas de junho daquele ano. Eram seguidas de um texto escrito pelo redator da Gazeta do Rio de Janeiro onde, entre comentários a respeito dos acontecimentos europeus, ele faz uma caracterização do governo francês em que repete a representação de Napoleão como um usurpador que não respeita acordos e nem honra tratados:

O governo francês ainda há pouco engodava a Prússia enquanto atacava a Áustria, enganava a Áustria enquanto combatia com a Prússia e Rússia, fazia protestações de amizade a Portugal e disfarçava com a Espanha enquanto tinha a contender com as principais potências do Norte, mandava a Rússia invadir a Suécia enquanto se apoderava da Dinamarca; mas agora empreende conjuntamente a conquista do Industão, a ocupação da Pérsia, a desmembração do Império Otomano, a invasão da Sicília, da Suécia, da Espanha, a sujeição de Portugal, a usurpação dos bens e privilégios da Igreja e a proteção da América espanhola. Se ainda pudesse haver

${ }^{139}$ Gazeta do Rio de Janeiro, $\mathrm{n}^{\circ}$ 6, 1 de outubro de 1808. É importante ressaltar que nem sempre a reprodução dos comentários dos redatores dos periódicos de onde foram retiradas as notícias pode ser interpretada como um consentimento do redator da Gazeta do Rio de Janeiro.

${ }^{140}$ CARDOSO, op. cit., p. 400. 
uma só pessoa que acreditasse de boa fé a doutrina francesa, bastariam estes fatos para lhe abrir de todo os olhos. ${ }^{141}$

A publicação no Rio de Janeiro das notícias sobre a guerra na Europa acontecia sempre com dois a três meses de atraso, o que não nos permite acompanhar com exatidão pela Gazeta a marcha dos acontecimentos. A citação seguinte é interessante para dar uma nítida idéia do longo trajeto que as notícias percorriam desde a Europa até o Rio de Janeiro:

\section{Rio de Janeiro 7 de abril}

Chegou no dia 4 do corrente a este porto um navio que partiu de Pernambuco a 22 de março, onde nesse dia havia chegado um navio de Lisboa com uma viagem de 29 dias, havendo partido dali a 21 de fevereiro, que trouxe as melhores notícias da continuação dos sucessos dos espanhóis contra os franceses na península, depois das primeiras desgraças, dizendo-se que Bonaparte voltou à França, onde havia insurreições, e que até chamava alguma tropa da que estava na península. (...) Parece que estas notícias mereciam todo o crédito em Lisboa, pois os negociantes daquela praça fizeram aos de Pernambuco grandes encomendas de açúcar e algodão, constando também que em Lisboa se achavam embarcações de Trieste que tinham vindo buscar estes gêneros de que havia ali grande necessidade. ${ }^{142}$

A primeira expulsão dos franceses do território português, em finais de 1808 foi amplamente noticiada. Ainda no mês de setembro de 1808, o periódico dedica dois números para dar notícias sobre a expulsão dos franceses do Algarve (Gazeta do Rio de Janeiro $\mathrm{n}^{\mathrm{os}} 4$ e 5, de 24 e 28 de setembro). Em procedimento muitas vezes repetido, depois de publicar o extrato de variada correspondência chegada daquela província, o redator escreve um longo comentário de cunho patriótico, no meio do qual indaga:

As outras províncias de Portugal, vendo aceso no Algarve o nobre fogo do patriotismo, ficarão espectadoras ociosas dos esforços dos seus compatriotas? Os portugueses, que em diferentes épocas tem por mais de uma vez expelido os seus opressores em toda parte do mundo, que tem por brasão o amor da religião, dos soberanos e da pátria, (...) esquecer-se-ão do antigo brio agora que o Algarve lhe apresenta o exemplo? É de esperar que não, pois em todo o reino se manifestam palpáveis sinais de decidida revolta. ${ }^{143}$

\footnotetext{
${ }^{141}$ Gazeta do Rio de Janeiro, no 1,10 de setembro de 1808. No segundo número do periódico encontramos outro comentário do redator a respeito do caráter de Napoleão: "A máxima constante da política do imperador dos franceses é atacar as potências pela sua fidelidade às alianças contraídas. (...) Deste princípio usou já para roubar o reino de Nápoles ao seu legítimo soberano, já para invadir Portugal e agora, enfim, para lançar fora dos Estados da Igreja o Santo Padre". Gazeta do Rio de Janeiro, $\mathrm{n}^{\circ} 2,17$ de setembro de 1808.

${ }^{142}$ Gazeta Extraordinária do Rio de Janeiro, $\mathrm{n}^{\circ}$ 25, 7 de abril de 1809.

${ }^{143}$ Gazeta do Rio de Janeiro, no 5, 28 de setembro de 1808. A edição de 4 de fevereiro de 1809 reproduz uma proclamação dos governadores do Reino de 9 de dezembro de 1808 onde se lê a seguinte exortação, que lança mão dos feitos históricos da nação portuguesa: “Às armas,
} 
Os reveses portugueses e dos seus aliados, por outro lado, são sempre noticiados de forma indireta ou acompanhados de comentários do redator. A segunda invasão francesa, ocorrida em março de 1809, é noticiada no Rio de Janeiro apenas na edição extraordinária de 16 de maio a partir da cópia de uma ordem geral do Marechal Beresford publicada em Lisboa em 4 de abril, onde se comunica a queda da cidade do Porto. ${ }^{144}$ Nada mais se publica sobre o assunto até a edição de 21 de junho, que traz uma proclamação do Marechal Soult aos portugueses, intercalada de comentários patrióticos que parecem feitos pelo redator do periódico de onde ela foi copiada, onde este procura refutar ponto por ponto as afirmações do comandante francês:

Proclamação do Marechal Soult aos portugueses

Em consequiência dos sucessos memoráveis que tem havido em Espanha, o exército de S.M. o Imperador e Rei, meu Augusto Soberano, outra vez se apresenta no vosso território e deve, em nome do mesmo Senhor ocupar aí toda superfície.

Já quando no mês de fevereiro intentaram os franceses atravessar o Minho, nos enviaram adiante sua papeleta com o ridículo nome de Proclamação. Foram, então, destroçados e passaram a buscar a fronteira de outra província mais aberta $e$ onde supõem, por isso, menos obstáculos. Porém enganam-se, que os peitos Transmontanos, ajudados pelos corpos disponiveis das outras províncias lhes oporão uma barreira de bronze. Poderão ocupar algumas terras limítrofes, porém uma contínua e mortífera guerra lhes fará abandonar sua empresa. Deve ocupar toda superfície! Como os senhores têm nisso vontade, é o que basta. O seu dever não conhecerá outras regras para fazer guerras bárbaras, injustíssimas, e atropelar nações inocentes? Senão de onde nascerá uma tal dívida de nossa parte $?^{145}$

portugueses, às armas. A necessidade exige que a massa da nação empunhe as armas, e todas as armas na mão robusta de um defensor da pátria são instrumentos decisivos da vitória. (...) Dir-sehá, porventura, que não somos os descendentes dos valorosos lusitanos, que tanto tempo zombaram do valor e da perfídia dos exércitos romanos? Não foram os nossos antepassados que os que expulsaram destes reinos os belicosos árabes? Não somos nós os que fizemos tremer as costas da África? Os que fomos estabelecer no oriente um dilatadíssimo império? Os que temos sabido sempre defender a coroa dos nossos soberanos e a nossa independência nacional?". Gazeta do Rio de Janeiro, $\mathrm{n}^{\circ} 42,4$ de fevereiro de 1809.

144 "Soldados, o Marechal Comandante em Chefe já vos comunicou os sucessos que houveram no Norte. Ele tem tanto cuidado de vos comunicar os acontecimentos favoráveis como os contrários às armas da nação. (...) O Marechal dá parte ao exército que o inimigo, tendo-se apoderado de Braga, avançou com cautela e devagar contra a cidade do Porto, encontrando pelo caminho pouca resistência, pois que a insubordinação do povo tornou inútil o seu próprio valor e os esforços dos seus oficiais para retardar e impedir a sua aproximação. (...) Assim, se acha por agora o inimigo de posse da cidade do Porto. Por grande que seja a pena com que o Marechal soube da perda desta importante cidade, sente ainda mais a desgraçada causa, a qual ele manifesta para servir de admoestação e de uma lição memorável para que se evitem no resto do Reino as conseqüências fatais da anarquia e insubordinação." Gazeta Extraordinária do Rio de Janeiro, no 29, 16 de maio de 1809.

${ }^{145}$ Gazeta do Rio de Janeiro, no 81, 21 de junho de 1809. 
Mas, já na edição de 5 de julho começam a ser publicadas notícias sobre o início da campanha que resulta na segunda expulsão dos franceses, ocorrida efetivamente em maio. Dessa forma, enquanto a segunda ocupação francesa de Portugal durou aproximadamente dois meses, no Rio de Janeiro a divulgação das notícias da invasão e da expulsão dos franceses teve um intervalo de apenas duas semanas:

Por notícias vindas de Lisboa e dadas pelo mestre do navio Flor de Pernambuco, proximamente chegado a este porto com 30 dias de viagem; por cartas de João Antonio Vieira Caldas, negociante daquela praça, e de José Pedro da Costa Barradas, Juiz de Fora da vila de Recardães, consta terem já partido de socorro à cidade do Porto invadida pelo inimigo 19.000 homens, em cujo número entram 4.000 portugueses, esperando-se todos os dias a notícia da retomada da dita cidade pelos nossos e pelos ingleses. Que o inimigo já estava fora de Guimarães e Braga. Que tinha sido expulso de quase toda a Galiza e batido em muitos pontos. Que eram grandes os socorros da Inglaterra tanto para a Espanha quanto para Portugal e muitos os donativos nacionais. (...) Que os franceses do Porto já pediam capitulação, a qual se lhes havia negado. ${ }^{146}$

Da mesma forma que nos panfletos políticos, os exércitos franceses são representados na Gazeta do Rio de Janeiro sempre como bárbaros e heréticos que não respeitam a religião católica, profanando templos, matando padres e roubando bens das igrejas das localidades por eles invadidas ou utilizando-as para a acomodação das tropas e, pior, dos cavalos. Esse é o teor de uma carta do Alcaide-mor da localidade de Brozas em que relata a invasão do exército francês àquela cidade, publicada na edição de 11 de outubro de 1809:

Os templos foram horrivelmente profanados por estes malvados, Mutilaram as imagens e até se supõe que queimaram algumas, porque se não acham e só deixaram os crucifixos. As igrejas serviram-lhes de cavalariças, não para recolher simplesmente os cavalos mas servindo-se dos altares para deitarem a palha, centeio e cevada, tudo junto. Rasgaram os ornamentos e creio que não ficou um só em estado de poder servir para o culto divino. ${ }^{147}$

Mais exemplos de desrespeito com a religião católica podem ser encontrados nas narrativas da retirada do exército francês do território português

\footnotetext{
${ }^{146}$ Gazeta do Rio de Janeiro, ${ }^{\circ} 85,5$ de julho de 1809 . No mesmo número é publicada uma carta particular, recebida por um negociante do Rio de Janeiro, onde se reforça as boas novas: "Calculase, aqui, que a 12 deste mês estará concluída a guerra na cidade do Porto; e depois vão a entrar em Espanha, entre portugueses e ingleses, 150.000 homens a acabar o resto dos franceses que há na Espanha. Assim o tem determinado o governo inglês, e para isto já fez desembarcar em Lisboa 40.000 homens de infantaria e cavalaria; e no dia em que saiu a Flor de Pernambuco, entraram 124 navios com tropa e já saíram outros tantos a ir buscar mais gente. Deus queira que as coisas se verifiquem do modo que estão projetadas". Ibid.

${ }^{147}$ Gazeta do Rio de Janeiro, $\mathrm{n}^{\circ} 113,11$ de outubro de 1809.
} 
em 1811, após sua terceira invasão ocorrida em agosto do ano anterior. Como explica Lúcia Bastos, os franceses chegaram a apoderar-se de Coimbra, mas após a derrota na batalha do Bussaco, a 27 de setembro, noticiada nas edições de 4, 5 e 12 de janeiro, ${ }^{148}$ foram obrigados a recuar:

Travou-se então prolongada guerra de usura, recorrendo os dois lados à tática de terra arrasada, o que provocou fome e devastação entre os portugueses, mas que também desgastou as tropas napoleônicas, cercadas por uma população hostil, as quais começaram a retirada em março de 1811, embora só em outubro tenham atravessado a fronteira espanhola. ${ }^{149}$

A edição de 8 de junho traz extratos de uma carta datada de 25 de março, e publicada na Gazeta de Lisboa de $1^{\circ}$ de abril, sobre a retirada dos franceses da localidade de Tomar. A correspondência, além de se referir às "providências" tomadas pelos franceses para garantir uma retirada rápida e segura, repete o rol de barbaridades que teriam sido cometidas pelos invasores contra os habitantes locais e as igrejas:

Os franceses entraram nesta vila no dia 20 de outubro de 1810 e acabaram de sair dela a 7 de março de 1811, pelas 7 da manhã; entrando a guarda avançada do exército combinado pouco mais de um quarto de hora depois de ter saído o inimigo. (...) Em todo o tempo que estiveram nesta vila, praticaram os mais horrorosos delitos e insultos: mataram muitas pessoas de ambos os sexos e de todas as idades, de que ainda se não pode dar a conta exata. E isto nos arrabaldes da vila e seu termo. Roubaram todas as casas e deitaram abaixo parte delas; cortaram e lançaram ao fogo muitos olivais; destruíram todas as igrejas e capelas e conventos; queimaram e despedaçaram todas as imagens, arrombaram os sacrários e, roubando os vasos sagrados, lançaram por terra e pisaram as sagradas partículas; e ainda o que acabo de referir não é mais do que um quadro imperfeito da triste e horrorosa cena que oferece este distrito. ${ }^{150}$

A edição de 10 de julho traz a cópia de uma carta, datada de 30 de abril, relatando a passagem dos exércitos franceses pela cidade de Alcobaça:

Cheguei a esta vila e encontrei ainda muitos vestígios da precipitada fugida de

\footnotetext{
148 Ofício do Tenente General Lord Visconde Wellington ao Conde de Liverpool, datado em Coimbra no dia 30 de setembro (Gazeta Extraordinária do Rio de Janeiro, $\mathrm{n}^{\circ}$ 1, 04 de janeiro de 1811 e Gazeta do Rio de Janeiro, $\mathrm{n}^{\circ}$ 2, 05 de janeiro de 1811); e carta particular datada de Coimbra de 29 de setembro de 1810 (Gazeta do Rio de Janeiro, $\mathrm{n}^{\circ} 4,12$ de janeiro de 1811).

${ }^{149}$ NEVES, op. cit., p. 111. Em despacho de Massena datado de 27 de outubro de 1810 relativo à Batalha do Bussaco e interceptado pelas forças aliadas, publicado na Gazeta de 20 de fevereiro de 1811, o general francês afirma que "O inimigo queima e destrói tudo à proporção que evacua o país, e obriga os habitantes a abandonar seus lares. Coimbra, cidade de 20 mil habitantes, está deserta. Nós não achamos provisões. O Exército se sustenta de milho e dos vegetais que ficaram na terra". (Gazeta do Rio de Janeiro, $\mathrm{n}^{\circ}$ 15, 20 de fevereiro de 1811).

${ }^{150}$ Gazeta do Rio de Janeiro, $\mathrm{n}^{\circ}$ 46, 8 de junho de 1811.
} 
Massena. (...) Tenho observado com atenção as espantosas ruínas deste mosteiro. Confesso-lhe que me parecem mais horríveis do que julgava. A igreja toda denegrida pelas chamas, que consumiram totalmente o coro, as naves que sustentavam os órgãos, todas estaladas, oferecem um golpe de vista muito desagradável. Nota-se que as imagens de Jesus Cristo Nosso Salvador e de Nossa Senhora foram as mais insultadas, aparecendo quase todas inteiramente desfiguradas ou com as cabeças cortadas. Outras têm os rostos denegridos e conhece-se que é por lhes terem aplicado velas acesas. Enfim, a religião dos soldados de Bonaparte aparecerá em toda a sua luz a quem examinar a igreja de Alcobaça. ${ }^{151}$

Maria Beatriz Nizza da Silva sugere que os conceitos de extrato e narração poderiam resumir a atividade do redator da Gazeta do Rio de Janeiro na publicação das notícias sobre a guerra retiradas dos jornais europeus: "quando ele atuava de maneira mais pessoal, extraía notícias dos periódicos estrangeiros e elaborava uma súmula delas; quando interferia menos, limitava-se a seguir a narração alheia". ${ }^{152}$ Nem extrato nem narração, porém, alcançavam algo próximo a uma imparcialidade, apesar do discurso em contrário. Ressalta Juliana Gesuelli Meirelles que, desde o início da publicação do periódico, os comentários do redator realçavam um viés opinativo que, no entanto, os homens de Estado responsáveis pela sua circulação procuravam negar (o que marcava, inclusive, uma peculiaridade em relação ao tradicional modelo da Gazeta de Lisboa, escrita em um estilo mais seco e estritamente informativo). Afirma a autora que a difusão da idéia de imparcialidade teria sido uma importante preocupação da Gazeta que se manteve ao longo de todo o período joanino. ${ }^{153}$ Dessa forma, o redator da Gazeta acusava os periódicos franceses de serem parciais e tendenciosos, mas não reconhecia essa mesma característica no seu próprio trabalho.

A edição do periódico de 29 de abril de 1809, todavia, traz um artigo bastante esclarecedor sobre a forma como os letrados e homens de Estado portugueses concebiam o papel dos periódicos naquela conjuntura política, intitulado Discurso sobre a utilidade dos papéis públicos na presente guerra. ${ }^{154}$

\footnotetext{
${ }^{151}$ Gazeta do Rio de Janeiro, no 55, 10 de julho de 1811.

152 SILVA, M. B. N. da. op. cit., p. 10.

153 "Para os editores, porém, parecia ser fundamental dissuadir o público leitor da idéia da folha ser oficial, para que assim tentassem evitar associações arbitrárias entre os fatos e notícias veiculadas, e a ótica dos valores monárquicos". MEIRELLES, J. G. Imprensa e Poder na Corte Joanina: A Gazeta do Rio de Janeiro (1808-1821), p. 71.

154 Apesar de ter sido publicado anonimamente na Gazeta do Rio de Janeiro, explica Juliana Gesuelli Meirelles, que o artigo era de autoria de Soares Franco, professor de medicina em Coimbra e redator da Gazeta de Lisboa entre 1808 e 1812. Esse texto já era de conhecimento no
} 
Nesse artigo, o autor acusa os franceses de inaugurarem uma nova modalidade de guerra. Afirma ele que até a Revolução Francesa era possível calcular o resultado de uma guerra sabendo-se de antemão a riqueza do erário, o número das tropas, a habilidade dos generais e a sabedoria dos ministros das diversas potências beligerantes. Porém, a Revolução Francesa, no seu intuito de extinguir a religião e aniquilar a nobreza por toda a Europa, tal como fez na própria França, necessitava iludir os outros povos e os indispor contra seus próprios príncipes, representando os seus governos como "miseráveis, ilegais e incapazes de conduzirem a felicidade aos lares dos seus povos":

Então, se proclamou um novo gênero de guerra; uma guerra de direitos sociais que excite a desordem e a divisão até no centro das famílias. Divisão que correspondeu cabalmente aos diabólicos fins que se tinham proposto os Jacobinos de Paris, e que foi a principal chave que abriu as portas às conquistas francesas. Os papéis públicos vieram, em consequiência, a subministrar uma das principais armas aos exércitos franceses. ${ }^{155}$

Tal como faziam os autores dos panfletos políticos, o autor do artigo apresenta as campanhas de expansão napoleônicas como continuidade da Revolução Francesa e tece um longo elogio ao governo britânico, segundo ele o único da Europa que compreendeu "a força irresistível desta nova arma e tentou destruí-la com outra igual". Então, em Inglaterra:

Homens de talento que conheciam o estado político da Europa, foram incumbidos de desmascarar de diversas maneiras, conforme circunstâncias, as intrigas do Governo Francês, e de sustentar perpetuamente o espírito público e as operações do governo, inclinando-as umas vezes à paz, outras à guerra. ${ }^{156}$

Segundo o autor, foram os bons escritos periódicos que fizeram duplicar os recursos da Grã-Bretanha para ir à guerra contra a França. Dessa forma, a utilidade dos papéis públicos em tais conjunturas era fazer da guerra em que se luta uma guerra nacional, apresentando aos povos o seu verdadeiro estado político, suas forças, seus recursos ordinários e extraordinários e, principalmente, convencendo-os da sabedoria e do patriotismo de seus chefes. Para ele esses mesmos princípios deveriam ser seguidos por Portugal e Espanha:

Reino, pois havia sido publicado na edição de 6 de janeiro de 1809 na gazeta do Reino. Ibid., p. 98.

${ }^{155}$ Gazeta do Rio de Janeiro, $\mathrm{n}^{\circ}$ 66, 29 de abril de 1809.

${ }^{156}$ Ibid. 
É preciso que os escritos periódicos destas duas nações desmascarem os crimes e as intrigas do inimigo comum; é necessário que instruam os povos acerca da sua verdadeira situação e da sua força e recursos irresistíveis; mas é igualmente necessário que, ao mesmo tempo, lhes digam que estes grandes recursos e esta força não é irresistível senão quando as nações têm uma confiança cega e inteira no seu governo e nos seus chefes, quando esperam em tranqüilidade as ordens e as executam com prontidão. ${ }^{157}$

Com a publicação desse texto, o redator da Gazeta do Rio de Janeiro contrariava qualquer pretensão de imparcialidade por parte do periódico, deixando explícitos os objetivos que ele se via obrigado a perseguir, por dever patriótico, ao divulgar as notícias do front europeu no Rio de Janeiro: a utilização da palavra escrita como arma de combate, nas palavras de Lúcia Bastos. ${ }^{158} \mathrm{O}$ que ressalta a semelhança não só de linguagem, mas também de objetivos, entre os periódicos e os panfletos políticos publicados na mesma época; e deixa patente, mais uma vez, a relação intrínseca existente entre saber e poder na mentalidade ilustrada portuguesa, que se constituía em parte da herança que caracterizava o trabalho da Impressão Régia do Rio de Janeiro.

A análise das representações sobre Napoleão e o período de ocupação francesa de Portugal encontradas nos panfletos políticos e na Gazeta do Rio de Janeiro, procurou chamar a atenção para outro aspecto da construção da metamemória do Estado português, protagonizada pelo memorialismo histórico publicado pela Impressão Régia do Rio de Janeiro. Aqui, devido à semelhança entre as representações feitas em panfletos e periódicos, a disputa pela memória não se apresenta tão nitidamente quanto no caso das re-presentificações da transferência da Corte para o Rio de Janeiro. Muito certamente, em parte fruto da tríplice censura a que estava submetido o trabalho da Impressão Régia, que faz com que o discurso sobre a ocupação francesa de Portugal apareça homogêneo ao público leitor da capital do Império, dificilmente encontraríamos entre as publicações da tipografia, por mais que nos esforçássemos, trabalhos elogiando ou fazendo apologia da ocupação francesa. Apesar de termos a consciência, como visto nesse capítulo, que os franceses conseguiram angariar não poucos colaboradores durante o período de ocupação de Portugal.

\footnotetext{
157 Ibid.

${ }^{158}$ NEVES, L. M. B. P. das. Pensamentos vagos sobre o Império do Brasil, p. 473.
} 
Ao analisar as formas como foram abordados pelo memorialismo histórico ou político publicado não apenas pela Impressão Régia do Rio de Janeiro mas também por tipografias localizadas em Portugal, os acontecimentos ocorridos no Império Português na conjuntura da guerra contra a França, procurei chamar a atenção para o seu trabalho de re-presentifacação. Entendido por Fernando Catroga como uma reorganização ou reinterpretação das três dimensões temporais, atribuindo a acontecimentos passados novos sentidos relacionados às necessidades do presente e a projetos de futuro. Esse autor chama a atenção para o caráter totalizador e teleológico próprio da recordação, pois a retrospectiva, segundo ele, "esquecendo-se do esquecimento, cose um enredo finalístico que domestica o aleatório, o casual, os efeitos perversos e descontínuos do realpassado quando este foi presente". ${ }^{159}$ Conclui Catroga que, em certa medida, a recordação, assim como outras narrativas que exprimem a historicidade do homem, seria uma previsão ao contrário, onde o efeito seria a causa não confessada da sua própria causa. ${ }^{160}$ Essa operação interpretativa da memória tem como efeito a transformação do destino, sempre incerto e imprevisível, no resultado necessário e esperado de um projeto:

\begin{abstract}
A unidade do $e u$, ou melhor, a ipseidade (Ricoeur), atravessa os vazios da amnésia como se o percurso autobiográfico fosse um continuum, cuja coerência existencial unifica os buracos negros da caminhada, isto é, como se, desde as suas primícias, cada estratégia de vida fosse incidível do cumprimento de uma omnipresente vocação específica: a de se realizar como projeto. ${ }^{161}$
\end{abstract}

Como procurei mostrar, essa atividade de re-presentificação protagonizada pelo memorialismo histórico português buscava interpretar o passado, o presente e o futuro do Império Português em uma linha de continuidade, frente às ameaças de ruptura colocadas pela invasão do Reino pelos franceses e a transferência da Corte para o Rio de Janeiro. Entre passado e o futuro eram as necessidades do tempo presente que então ditavam, como ditam hoje ainda, a construção da memória. Recuperando o conceito cunhado por Hannah Arendt, podemos afirmar

\footnotetext{
${ }^{159}$ CATROGA, op. cit., p. 19.

${ }^{160}$ Ibid.

${ }^{161}$ Ibid.
} 
que aqueles homens viviam em uma brecha, um intervalo de tempo situado entre abismos, "totalmente determinado por coisas que não são mais e por coisas que não são ainda". ${ }^{162}$

Diante desse quadro, o trabalho de enquadramento da memória necessário à construção da metamemória do Estado português frente às diferentes memórias em disputa a respeito dos acontecimentos que cercaram a partida da Corte e a invasão francesa do Reino, realizado por atores sociais diretamente ligados ao aparelho de Estado, tais como Silva Lisboa, Acúrsio das Neves, José Caetano da Silva Coutinho ou Frei Tibúrcio José da Rocha e Manuel Ferreira de Araújo Guimarães (redatores da Gazeta do Rio de Janeiro e de O Patriota), evitava a divulgação de outras memórias e, portanto, outros projetos discordantes daquele que se apresentava momentaneamente como o vitorioso: o projeto de reconstrução do Império Português na América. Como ressalta Roger Chartier, essas "lutas de representação têm tanta importância como as lutas econômicas para compreender os mecanismos pelos quais um grupo impõe, ou tenta impor, a sua concepção do mundo social, os valores que são seus, e o seu domínio". ${ }^{163}$

A partir do momento em que estabelece um fio de continuidade na experiência do tempo no Império Português, o memorialismo histórico da Impressão Régia se apresenta também como mais um aspecto da construção da herança ilustrada portuguesa. Reinterpretando os acontecimentos da primeira década do século XIX de forma a apresentar a transferência da Corte portuguesa para o Rio de Janeiro como a execução de um projeto político gestado no ambiente ilustrado português, ignorava a dimensão de ruptura intrínseca ao processo que levou à execução desse projeto, assim como as reações negativas a ele que partiam, principalmente mas não exclusivamente, dos súditos deixados para trás no antigo reino.

\footnotetext{
${ }^{162}$ ARENDT, op. cit., p. 35/36.

${ }^{163}$ CHARTIER, R. A História Cultural: Entre práticas e representações, p. 17
} 


\section{Considerações Finais}

Ao eleger como objeto de pesquisa uma instituição cultural criada durante a instalação da Corte portuguesa no Rio de Janeiro, eu buscava mais uma vez, assim como procurei fazer na minha dissertação, questionar a representação de d. João como um monarca de pouca cultura, sem nenhuma inclinação pelas artes e pela ciência e afeito apenas à liturgia religiosa. Representação essa ainda muito fácil de encontrar hoje em dia em livros e filmes que elegem o chamado período joanino (1808-1821) como objeto. Meu objetivo primeiro era ressaltar como a criação de uma tipografia na sede do novo império português e a consequente multiplicação das publicações de caráter científico e artístico durante o seu reinado no Rio de Janeiro, apontavam para a intenção de construção de uma monarquia ilustrada.

Porém, apesar da natureza predominantemente cultural da Impressão Régia do Rio de Janeiro, a análise da sua atuação me levou a atentar também para o papel político que exercia, como parte que era do aparelho burocrático de administração do Império português. Por trás das tarefas cotidianas da tipografia, e orientando a sua atuação, estava algo ao qual devotavam especial atenção os letrados e estadistas luso-brasileiros responsáveis pela sua gestão: a realização do projeto político de construção de um novo Império português na América. A Impressão Régia apresentava-se, dessa forma, como a face cultural daquele projeto. Se é possível atribuir um sentido geral à sua atuação, e essa é a tese defendida nesse trabalho, é o papel político que a tipografia desempenhou na legitimação e sustentação desse projeto. Ressaltando a relação intrínseca existente entre cultura e poder nas monarquias absolutas.

Essa tentativa de construção de um novo império português na América era feita sobre o patrimônio intelectual da Ilustração portuguesa. Erigido em herança pelos letrados e estadistas ilustrados portugueses dos dois lados do Atlântico responsáveis por aquela construção. A ideia da transferência da sede da monarquia para a sua principal colônia era, ela mesma, um fruto do ambiente ilustrado português, ${ }^{1}$ e ao ser finalmente posta em prática, atendia não somente a

\footnotetext{
${ }^{1}$ Como procurei ressaltar, a ideia da transferência havia sido considerada por diversos estadistas e letrados portugueses desde a restauração da monarquia em 1640, mas ganhou força durante o século XVIII, no contexto do reformismo ilustrado, à medida mesmo em que o Brasil ia se
} 
uma necessidade conjuntural imediata, mas efetivava o projeto reformista ilustrado de re-construção do Império português. Ao fazer parte desse projeto político, exercendo a sua função de propaganda e censura, como divulgadora das Luzes no Império e integrante do aparato censório do Estado português instalado no Rio de Janeiro, a Impressão Régia é também interpretada, nesse trabalho, como herdeira do reformismo ilustrado português.

O memorialismo científico difundia o conhecimento das Luzes na nova sede do Império Português, fazendo repercutir na América portuguesa o patrimônio intelectual da Ilustração portuguesa, fosse por meio da tradução de manuais estrangeiros de matemática, medicina ou direito, fosse por meio da publicação ou reedição de memórias História Natural e Economia Política de autores estrangeiros ou portugueses. Mas, principalmente, buscando manter o espírito pragmático e utilitário da Ilustração portuguesa, cujo principal objetivo era superar o atraso cultural e a decadência política e econômica em que se encontrava o Império. Enquanto o memorialismo histórico/político buscava construir e divulgar a versão oficial dos fatos políticos do passado recente, que levaram a monarquia à situação que então se encontrava. Principalmente as invasões francesas do Reino e a consequente transferência da Família Real Portuguesa para a América. Construindo uma linha de continuidade entre passado, presente e futuro da monarquia portuguesa, evitando as ameaças de ruptura colocadas pelos acontecimentos políticos recentes e transformando um momento de fraqueza em ponto de partida de um futuro glorioso para a monarquia.

No entanto, como procurei ressaltar, a transferência da sede do império português para a colônia (e a sua principal consequencia, o fim do exclusivo comercial) significou uma profunda modificação em relação ao que havia sido proposto nos planos do reformismo ilustrado português. A transplantação da Corte para o Estado do Brasil criava uma situação nova onde o antigo Reino perdia o papel de centro do império e nexo da unidade imperial, provocando uma inversão da reciprocidade entre as partes componentes do Império, relegando os

afirmando como a parte economicamente mais importante do Império devido ao aumento da produção da cana-de-açúcar e, principalmente, a descoberta de metais preciosos nas Minas Gerais; e frente ao encolhimento do império português na África e no Oriente. Como mostram as viagens filosóficas e as memórias de História Natural produzidas no último quartel do século XVIII português. 
interesses da nobreza e dos comerciantes reinóis a segundo plano. A insatisfação gerada do outro lado do Atlântico português revelava a ruptura na comunidade de interesses necessária à realização do ideal do poderoso império concebido pela Ilustração portuguesa.

Essa ruptura de interesses ficará mais evidente a partir do fim do conflito europeu, em 1815. Como afirma Ana Rosa Cloclet da Silva, intensificava-se, a partir de então, o debate sobre qual deveria ser o lugar hegemônico do poder no mundo luso-brasileiro: "os anos de 1814-1815 marcam uma definitiva polarização dos projetos e interesses em causa. O fim da guerra eliminava, na perspectiva dos governadores do Reino, qualquer empecilho à volta do monarca".2 Porém, por decreto de 16 de dezembro de 1815, contrariando as expectativas, o PríncipeRegente eleva o Brasil a condição de Reino Unido a Portugal e Algarves, eliminando, assim, o estatuto colonial da possessão americana e justificando a sua permanência na América. Como explica Maria de Lourdes Viana Lyra, a decisão foi embasada pelo pensamento do reformismo ilustrado, que justificava a opção pela permanência da sede da monarquia no Reino mais promissor. Assim, "o governo demonstrava aos súditos do Reino europeu o quanto era imprescindível à prosperidade da Monarquia a riqueza do Brasil, colocada como exigência básica ao novo império que se queria poderoso". 3

Na Gazeta do Rio de Janeiro, a primeira notícia sobre a Elevação foi dada de maneira sóbria e discreta, em uma pequena nota publicada na edição de 20 de dezembro de 1815:

Havendo-se publicado nesta corte a Carta de Lei de 16 do corrente, pela qual Sua Alteza Real houve por bem elevar o Brasil a Reino e assumir o título de Príncipe Regente do Reino Unido de Portugal, do Brasil e dos Algarves, o público desta cidade se apressou a dar as demonstrações do mais completo júbilo, iluminando-se espontaneamente um grande número de edifícios. ${ }^{4}$

Já a edição de 10 de janeiro de 1816 trata quase exclusivamente do assunto, publicando a íntegra da Carta de Lei de 16 de Dezembro "Por ordem superior", como informa o cabeçalho; e reproduzindo a fala que o Presidente do Senado da Câmara do Rio de Janeiro fez em 28 de dezembro de 1815, na presença do

\footnotetext{
${ }^{2}$ SILVA, A. R. C. Inventando a nação: Intelectuais ilustrados e estadistas luso-brasileiros na crise do Antigo Regime português (1750-1822), p. 246.

${ }^{3}$ LYRA, op. cit. p. 155.

${ }^{4}$ Gazeta do Rio de Janeiro, $\mathrm{n}^{\circ}$ 101, 20 de dezembro de 1815.
} 
Príncipe Regente, assim como a resposta dada por D. João. O texto da Carta de Lei justifica o ato como a correção de uma injustiça, ao elevar o Estado do Brasil a um status político condizente com a sua importância dentro do Império português:

Faço saber aos que a presente Carta de Lei virem, que tendo constante em meu Real ânimo os mais vivos desejos de fazer prosperar os Estados que a Providência Divina confiou ao meu Soberano Regime; e dando, ao mesmo tempo, a importância devida à vastidão e localidade dos meus domínios da América, a cópia e variedade dos preciosos elementos de riqueza que eles em si contêm; e, outrosim, reconhecendo quanto seja vantajosa aos meus fiéis vassalos em geral uma perfeita união e identidade entre os meus Reinos de Portugal e dos Algarves, e os meus domínios do Brasil, erigindo estes àquela graduação e categoria política que pelos sobreditos predicados lhes deve competir, (...) sou, portanto, servido e me praz ordenar o seguinte: I. Que desde a publicação desta Carta de Lei o Estado do Brasil seja elevado à dignidade preeminência e denominação de Reino do Brasil. II. Que os meus reinos de Portugal, Algarves e do Brasil formem d'ora em diante um só e único Reino debaixo do título de Reino Unido de Portugal e do Brasil e Algarves. III. Que os títulos inerentes à Coroa de Portugal e de que até agora hei feito uso, se substitua em todos os Diplomas, Cartas de Lei, Alvarás, Provísões e Atos Públicos o novo título de Príncipe Regente do Reino Unido de Portugal e do Brasil e Algarves d'aquem e d'além mar, em África de Guiné e da conquista, navegação e comércio da Etiópia, Arábia, Pérsia e da Índia, etc. ${ }^{5}$

Essa concepção da preeminência da América portuguesa no interior do Império, pela sua extensão territorial, posição geográfica e riqueza, justificativa da permanência da Corte no Rio de Janeiro, pode ser vista também no tratamento que José da Silva Lisboa dispensa ao ato de elevação na sua Memória dos Benefícios Políticos do governo d'El Rei D. João VI. Segundo o letrado bahiense, a declaração do Reino Unido era um benefício que sobreexcedia a sua esfera de fraseologia. A medida vinha corrigir uma injustiça cometida pelo sistema colonial, que encarava "como simples feitoria comercial, estreita ilha de sotavento ou agreste sesmaria dos trópicos", uma porção do Globo "que tanto avultava no mapa do Mundo". Enquanto a antiga Metrópole seria um Estado de "circunscrito recinto, lutando com os inconvenientes de população estacionária, comércio passivo, inveterados ciúmes de potências rivais"; o Brasil sobressaía "em

\footnotetext{
${ }^{5}$ Gazeta do Rio de Janeiro, $\mathrm{n}^{\circ}$ 3, 10 de janeiro de 1816. Edições subsequentes do periódico publicam relatos de como a notícia da criação do Reino Unido foi recebida nas demais capitanias e, mesmo, fora do Império Português. Particularmente interessantes são as publicações do anúncio da Elevação feitos na Corte de Londres por Cypriano Ribeiro Freire, ministro plenipotenciário do Portugal naquela corte, noticiada pela Gazeta em 11 de maio; e na Corte da Suécia e Noruega, feita na edição de 24 de julho. Diante dessa profusão de notícias sobre o recebimento da Carta de 16 de dezembro de 1815, salta aos olhos a ausência na Gazeta do Rio de Janeiro de qualquer menção sobre a forma como a medida foi recebida em Portugal.
} 
incomparabilidade de meios de erguer fronte altiva, para se fazer respeitar das Nações amigas e suplantar assaltos da inveja e malignidade de quaisquer perturbadores públicos". 6 Pela perspectiva da antiga colônia, a nova situação significou a instalação de uma completa igualdade entre os habitantes dos dois hemisférios. A Memória de Silva Lisboa é exemplar para expressar esse sentimento de que um espírito de nacionalidade, entenda-se nacionalidade portuguesa, unia os habitantes dos dois continentes e avivava o homogêneo corpo político da monarquia,

por novo sistema conciliador, que até implicitamente exterminou a vulgar nomenclatura, que impoliticamente separava como distintas classes e castas os vassalos do mesmo soberano, unidos aliás por idênticos vínculos de sangue, afetos de famílias e laços de religião, língua e lei. Perfeita concórdia é o símbolo do governo patriarcal que olha e ampara com benignidade protetora a quantos se aprazem de sua doce regência. ${ }^{7}$

Dessa forma, o ano de 1815 e a elevação do Brasil a Reino se apresenta como um segundo momento de reforma da reforma, consolidando a situação criada pelo primeiro momento, que foi o ano de 1808 e a transferência da Corte para o Rio de Janeiro. Porém, apesar de concebida como medida que reforçaria, ao invés de enfraquecer, os laços entre Portugal e Brasil, consolidando a unidade que se queria inerente ao novo império português, a criação do Reino Unido serviu para explicitar tensões existentes no interior do Império. Enquanto o novo status era comemorado com euforia no Rio de Janeiro, era lamentado com desolação em Portugal. Como sintetiza Ana Rosa Cloclet, "o que para uns significava a instituição da igualdade e o fim da rivalidade entre "Povos Irmãos",

\footnotetext{
${ }^{6}$ LISBOA, J. da S. Memória dos Beneficios Políticos do governo d'el Rei D. João VI, p. 115/116.

${ }^{7}$ Ibid., p. 116. Ana Cristina Fonseca Nogueira da Silva aponta para 1815 como o momento em que a representação política do ultramar se afirmou, pela primeira vez, como o instrumento de recriação, em termos igualitários, desse conjunto territorialmente disperso mas, politicamente unido, que era o império português: "A unidade da representação política seria, então, a expressão da unidade da Nação. Mas seria também um instrumento (re)fundador, com o qual se afastariam indesejadas desigualdades, que eram atribuídas ao regime anterior, e se reconstruiria, mas em termos igualitários, a relação entre as 'partes' que constituíam o todo (ameaçado) da Monarquia. (...) A representação política era uma forma ativa de recriação da unidade, em termos tais que ela pudesse ser conservada”. SILVA, A. C. F. N. da. Nação federal ou nação bi-hemisférica? O Reino Unido de Portugal, Brasil e Algarves e o "modelo" colonial português do século XIX, p. 73/74. Analisando os debates sobre representação política nas cortes constituintes portuguesas de 1822 , explica a autora que o conceito de nação unitária pluri-continental, expresso na fórmula do Reino Unido, se apresentava então aos deputados portugueses como uma alternativa tanto ao antigo sistema colonial quanto ao modelo federativo, como o vigente no Império Britânico.
} 
para outros aparecia como a inadmissível inversão do pacto colonial". ${ }^{8}$ O decreto confirmava definitivamente a inversão do princípio de reciprocidade entre as partes do Império. Os habitantes da antiga metrópole se consideravam agora reduzidos à condição de 'colônia' do Brasil.

Por um lado, com o término da guerra na Europa, os efeitos do Decreto de abertura dos portos e do tratado de 1810 passavam a ser menos suportáveis, e a pressão da burguesia metropolitana para reaver sua antiga exclusividade no comércio do Brasil, bem como maior proteção alfandegária em Portugal, ascendia na mesma proporção das reivindicações pela volta do rei. Por outro lado, os setores coloniais beneficiados com a presença da Corte já contavam com toda uma conformação de interesses e um status político-econômico não passíveis de serem simplesmente abolidos, revertidos ou ignorados. Os comerciantes do Brasil, contando já com todo um favorecimento de interesses econômicos locais propiciados pelas medidas joaninas, estavam longe de conceber a propagada reciprocidade de interesses entre os Reinos nos termos dos antigos laços de exclusividade mercantil. ${ }^{9}$ Como afirma Maria de Lourdes Viana Lyra: “Conciliar interesses opostos continuava a ser o grande desafio do reformismo ilustrado. Para realizar a necessária aliança entre dois reinos pressupunha-se a existência de propósitos comuns e estes pareciam cada vez mais distantes entre si”. ${ }^{10}$

Outro momento crucial de questionamento do projeto do novo império português, consolidado na fórmula do Reino Unido, foi o ano de 1817. Naquele ano, a monarquia enfrentou dois movimentos políticos de oposição, um em Portugal e outro no próprio Reino do Brasil, que revelaram os limites da constituição daquele sentimento de identidade comum, essencial à realização do ideal ilustrado do poderoso império, ao proporem governos próprios desvinculados do Rio de Janeiro e da Casa de Bragança. Como explica Ana Rosa

\footnotetext{
${ }^{8}$ SILVA, A. R. C. da, op. cit., p. 261.

${ }^{9}$ Esse processo de enraizamento de interesses metropolitanos em território colonial, expresso nos investimentos locais realizados pelos principais homens de negócios da Corte, foi analisado por Maria Odila da Silva Dias, que o denominou de processo de interiorização da metrópole: "A vinda da Corte com o enraizamento do estado português no Centro-Sul daria início à transformação da colônia em metrópole interiorizada. (...) Ainda está por ser estudado mais a fundo o processo de enraizamento da metrópole na colônia, principalmente através da organização do comércio de abastecimento do Rio e conseqüente integração do Centro-Sul; as inter-relações de interesses comerciais e agrários, os casamentos com famílias locais, os investimentos em obras públicas e em terras ou no comércio de tropas e muares do Sul, no negócio do charque". DIAS, M. O. da S., A interiorização da metrópole (1808-1853), p. 171.

${ }^{10}$ LYRA, op. cit., p. 162.
} 
Cloclet, se, por um lado, contrapunham-se o "inegável sentimento de orfandade" pelo qual foram tomados os súditos peninsulares, às entusiásticas expectativas das elites coloniais com a situação criada, nutridas pela percepção de que a proximidade ao centro decisório de poder poderia trazer-lhes benefícios concretos e maior possibilidade de participação na gestão da coisa pública; por outro lado, expectativas positivas criadas com a vinda da Corte não ofuscaram o potencial de conflito interno que a nova situação instalava:

A perspectiva dos benefícios regionalizados, pela qual eram movidas as elites coloniais, implicava que, muitas vezes, eles fossem pleiteados em contraposição aos interesses de outras capitanias, denotando ausência de uma identidade de interesses entre seus membros, capaz de dar coesão ao veiculado ideal de Império. ${ }^{11}$

Enquanto as perspectivas do novo Reino mostravam-se promissoras para os comerciantes e estadistas domiciliados na nova capital do Império e na região por ele polarizada, as demais províncias ficaram praticamente marginalizadas dos benefícios que poderiam advir da nova condição política. ${ }^{12} \mathrm{O}$ estabelecimento da Corte no Rio de Janeiro, em vez de regalias e privilégios, trouxe para esses habitantes das outras regiões coloniais, um excesso de cobranças e imposições:

A fim de custear as despesas de instalação de obras públicas e do funcionalismo, aumentaram os impostos sobre a exportação do açúcar, tabaco, algodão e couros, criando-se ainda uma série de outras tributações que afetavam diretamente as capitanias do Norte, que a Corte não hesitava ainda em sobrecarregar com a violência dos recrutamentos e com as contribuições para cobrir as despesas da guerra no reino, na Guiana e no Prata. Para governadores e funcionários das várias capitanias parecia a mesma coisa dirigirem-se para Lisboa ou para o Rio. ${ }^{13}$

A denúncia dessa diferenciação irá explicitar-se por ocasião da Revolução Pernambucana de 1817. Pernambuco, mais especificamente as cidades de Olinda e Recife foram, assim como o Rio de Janeiro, núcleos ordenadores de uma importante região de agricultura-mercantil-escravista surgida durante o processo de colonização. As interpretações mais comuns do movimento revolucionário de 1817 chamam a atenção para a conjuntura de crise pela qual passavam as

\footnotetext{
${ }^{11}$ SILVA, op. cit., p. 237.

${ }^{12}$ Ao analisar o processo de interiorização da metrópole na colônia, Maria Odila da Silva Dias chamou a atenção para o nexo entre negócios e política que se estabeleceu entre a monarquia e a elite colonial com o estabelecimento da Corte no Rio de Janeiro. Nexo baseado na troca de apoio, financeiro principalmente, por honras e mercês, terras e títulos de nobreza. DIAS, op. cit., p. 160 a 184.

${ }^{13}$ Ibid., p. 182.
} 
capitanias nordestinas. ${ }^{14}$ Quadro que uma forte seca, que assolou a região no ano de 1816, veio agravar gerando escassez de alimentos. Acresce-se a esse quadro os crescentes impostos exigidos pela corte do Rio de Janeiro:

Às vésperas do movimento de 1817, a carga fiscal de Pernambuco compunha-se de quatro categorias: os impostos devidos a El Rei por toda a colônia; as contribuições criadas para custear a guerra holandesa; as antigas taxas donatariais que continuaram a ser cobradas mesmo após a transformação da capitania donatarial em capitania real, à raiz da restauração do domínio lusitano; e, por fim, os tributos exigidos a partir da instalação da Corte no Rio, como a contribuição anual de 40 mil cruzados para a reconstrução de Portugal, o imposto sobre o algodão, equivalente a $10 \%$ do seu valor, gravando-o duplamente de vez que ele já pagava o dízimo, e a imposição destinada à iluminação pública do Rio, que se tornou o símbolo da expoliação fiscal aos olhos da gente da terra, e à manutenção da Junta de Comércio ali erigida. ${ }^{15}$

Essa situação teria criado condições favoráveis para a proliferação das idéias liberais, discutidas em sociedades secretas pela intelligenzia pernambucana (clérigos, militares e burocratas). O movimento revolucionário de 1817 teve como estopim uma sedição militar no dia 6 de março que depôs o governador da capitania, instaurou um Governo Provisório e ganhou a adesão das capitanias vizinhas da Paraíba e do Rio Grande do Norte. ${ }^{16}$ Foi prontamente reprimido pelo governo do Rio de Janeiro. A 20 de maio o Recife já havia sido recuperado por tropas da Coroa vindas da Bahia e por uma esquadra vinda do Rio de Janeiro que bloqueou o porto daquela cidade, enquanto os revolucionários se refugiavam em Olinda. No dia 29 de junho entraram em Recife as tropas enviadas do Rio de Janeiro, sob o comando do General Luís do Rego Barreto, que também vinha nomeado novo governador de Pernambuco. Rego Barreto presidiu uma Comissão Militar que determinou o enforcamento e esquartejamento de doze líderes do movimento, acusados de crime de lesa-majestade, de acordo com as Ordenações do Reino. Outros participantes foram levados para Salvador, onde alguns foram

\footnotetext{
14 “O movimento eclodido em 1817 no Nordeste brasileiro está situado numa fase de recessão generalizada, cujas manifestações mais visíveis podem ser surpreendidas no nível das flutuações dos preços dos principais gêneros exportados. (...) Em particular, os preços do algodão e do açúcar nordestino indicavam a natureza da crise enfrentada pela ampla região polarizada pelo Recife". MOTA, C.G. Nordeste 1817: Estruturas e Argumentos, p. 14.

${ }^{15}$ MELLO, E. C. de. A outra independência: o federalismo pernambucano de 1817 a 1824. p. 29/30.

${ }^{16}$ Explicam Jorge Pedreira e Fernando Dores Costa que a proposta feita às tropas de lhes dar ração de pão em gêneros e de lhes pagar dezesseis soldos por saco de mandioca, vendido no mercado a cinquenta soldos, estão na origem da sedição militar que desencadeou a revolta. PEDREIRA, J. e COSTA, F. D. D. João VI: um príncipe entre dois continentes, p. 329.
} 
fuzilados e outros ficaram presos. Alguns conseguiram o perdão real até que as Cortes de Lisboa, instituídas pela Revolução do Porto (1820), libertaram os prisioneiros restantes. ${ }^{17}$ A violenta repressão ao movimento entende-se se atentamos para o fato de que, como ressalta Ana Rosa Cloclet, ele ameaçava quebrar a tradicional fidelidade dos vassalos de sua Majestade Fidelíssima. Do ponto de vista do projeto de construção do novo império português na América, a repressão ao movimento pernambucano de 1817 aparecia como oportunidade privilegiada para uma ação que, simultaneamente, eliminasse os dissidentes e convencesse os hesitantes a comporem o corpo político do Império. ${ }^{18}$

Segundo a interpretação mais comum, o movimento revolucionário de 1817 se caracterizaria por uma pregação republicana, separatista e de cunho nacionalista que oporia brasileiros a portugueses e anteciparia os sentimentos que levariam à separação definitiva entre metrópole e colônia em 1822. Seria, nas palavras de Oliveira Lima, um movimento "anti-dinástico" e "anti-português". ${ }^{19}$ Dessa forma, segundo síntese de Maria de Lourdes Viana Lyra: "O movimento revolucionário de 1817 significara então a entrada em cena, no mundo português, de um outro projeto de organização política calcado nos sedutores princípios da liberdade e da representação". ${ }^{20}$ E nesta concepção de soberania não havia lugar para o Rei.

O movimento foi noticiado na Gazeta apenas em 14 de maio de 1817, quando os acontecimentos já estavam se encaminhando para o seu desfecho. Chama a atenção o seu posicionamento na diagramação daquela edição. Apesar de extensa, a notícia aparece na segunda página e sem nenhum cabeçalho que lhe desse destaque ou que chamasse a atenção para ela. No texto, antes de passar ao relato factual do que havia ocorrido em Pernambuco nos dois meses anteriores, até a saída do Rio de Janeiro da tropa comandada por Rego Barreto, a 4 de maio,

\footnotetext{
${ }^{17}$ Para um relato factual detalhado do movimento ver PEDREIRA e COSTA, op. cit., p. 326 a 333.

${ }^{18}$ SILVA, A. R. C. da. op. cit., p. 268 a 273.

${ }^{19}$ LIMA, O. D. João VI no Brasil, p. 510. Em análise mais recente do movimento, Evaldo Cabral de Mello afirma que a reivindicação federalista de Pernambuco seria herança da aspiração autonomista existente desde o período colonial e teria se revestido de separatismo em 1817 devido à sua opção pela forma de governo republicana. A argumentação do autor é a de que a historiografia brasileira, sempre mais preocupada com o processo de centralização política do Império do Brasil, tendeu a não considerar a existência do projeto federalista pernambucano, encarando-o apenas como "produto de impulsos anárquicos e de ambições personalistas e antipatrióticas". (MELLO, op. cit., p. 14)

${ }^{20}$ LYRA, op. cit., p. 168
} 
o redator procurou justificar a ausência do tema nas páginas do periódico:

Temos demorado por longo tempo a comunicar os nossos leitores quanto nos constava dos desastrosos sucessos, acerca da revolta de Pernambuco, não tanto pelo horror que sentíamos em semelhante acontecimento, ainda que bem desejaríamos não manchar com tal atrocidade as páginas da História Portuguesa, tão distinta pelos testemunhos de amor e respeito que os vassalos desta nação consagraram ao seu soberano nas ocasiões de maior apuro e em distâncias mui remotas, mas para não adiantar fato, ou circunstância alguma em coisa por sua natureza tão odiosa de que não tivéssemos completa informação. ${ }^{21}$

Como se pode ler na citação, segundo a versão dos acontecimentos fornecida pela Gazeta, o movimento pernambucano era uma revolta e uma atrocidade, o que denotava desde o início o caráter negativo com que seria abordado pelo periódico. O redator afirma ter decidido escrever apenas quando teve a certeza de que a maioria da população de Pernambuco não tinha seguido os revoltosos:

Estando convencidos, assim como todos, de que os habitantes de Pernambuco não podiam ter-se alienado até o ponto de perderem os sentimentos de fidelidade e obediência que noutro tempo realçaram o seu caráter, não acertávamos como pode verificar-se a escandalosa ingratidão que acabavam de manifestar. As notícias mais individuais que ultimamente têm chegado nos tiram desta incerteza, mostrando que na funesta rebelião de Pernambuco não teve parte a maioridade de seus habitantes. E não nos arrependemos, por isso, de uma demora que serviu para confirmar a persuasão em que estávamos, e que tínhamos tanto a peito. ${ }^{22}$

Em contraposição à escassa e tardia veiculação de notícias feita pela Gazeta do Rio de Janeiro, A Idade d'Ouro do Brasil, periódico publicado em Salvador pela Tipografia de Manuel Antonio da Silva Serva, já havia noticiado os acontecimentos de Pernambuco desde a sua edição de 1 de abril. Segundo Maria Beatriz Nizza da Silva, durante os meses de abril, maio e junho praticamente não saiu um número que não trouxesse notícias ou comentários sobre a revolução. ${ }^{23}$ Como explica a autora, é compreensível que se tivesse notícia dos acontecimentos de Pernambuco na Bahia antes do que no Rio de Janeiro, uma vez que a antiga capital da colônia estava mais próxima do local dos eventos e, sobretudo, porque negociantes pernambucanos fugiram para lá. ${ }^{24}$ Mas, essa explicação justifica apenas em parte a demora da Gazeta em noticiar os fatos. Principalmente se

\footnotetext{
${ }^{21}$ Gazeta do Rio de Janeiro, $\mathrm{n}^{\circ}$ 39, 14 de maio de 1817.

${ }^{22}$ Gazeta do Rio de Janeiro, $\mathrm{n}^{\circ} 39,14$ de maio de 1817.

${ }^{23}$ SILVA, M. B. N. da. A Primeira Gazeta da Bahia: Idade d'Ouro do Brasil, p. 158.

${ }^{24}$ Ibid., p. 162.
} 
pensarmos que o redator da Gazeta provavelmente tinha acesso às edições da Idade d'Ouro do Brasil e, portanto, tinha conhecimento dos fatos, pelo menos, desde abril, mas preferiu omiti-los do público da Corte, à espera do seu desfecho. ${ }^{25}$ Jorge Pedreira e Fernando Dores Costa afirmam que desde 25 de março já havia conhecimento da Revolução Pernambucana na Corte, mas não informam de onde retiraram essa informação. ${ }^{26}$

A Gazeta do Rio de Janeiro volta a abordar os acontecimentos de Pernambuco nas edições de 17 e 21 de maio, e na Gazeta Extraordinária de 16 de junho. ${ }^{27}$ Nesta última se publica a cópia de um ofício do Conde dos Arcos, governador da Bahia informando sobre a chegada da expedição de Rego Barreto a Pernambuco e a sua entrada em Recife. ${ }^{28} \mathrm{O}$ assunto já parecia estar encerrado até que na edição de 16 de julho, o periódico volta ao assunto com a intenção de recapitular os acontecimentos e informar sobre o desfecho do episódio. O que faz o redator da Gazeta nessa edição é, nada mais nada menos, do que construir a memória oficial dos fatos, onde o movimento é representado como um "execrando crime" cometido por um "punhado de facionorosos". O texto comemora a vitória das forças governamentais sobre aqueles que ele denomina de rebeldes e facciosos:
A bem fundada esperança de que seriam efêmeros os resultados daquele frenesi, nos obrigava a corrermos ligeiros sobre tão fatais e inesperados acontecimentos. Porém, depois de havermos referido e aplaudido o triunfo da fidelidade sobre a perversidade, podemos mais a sangue frio repassar os olhos sobre aquela mal fadada época e, epilogando as circunstâncias ainda não referidas, completar assim a história daqueles dias, que deveriam ser apagados da série dos tempos se, de mistura com atentados, não mostrassem a fidelidade dos portugueses e a constância inabalável e a firme adesão com que respeitam a sagrada pessoa de Sua Magestade. $^{29}$

\footnotetext{
${ }^{25}$ As edições do mês de abril da Gazeta do Rio de Janeiro privilegiaram notícias estrangeiras. Chegando mesmo a publicar na íntegra uma fala do Presidente dos Estados Unidos da América do Norte, James Madison, que se estendeu por três números do periódico ocupando um dos quais inteiramente (Gazetas no 27,28 e 29 de 2, 5 e 9 de abril).

${ }^{26}$ PEDREIRA e COSTA, op. cit., p. 331.

27 A edição de 17 de maio publica uma carta enviada pelo Juiz dos Órfãos da Vila de Serinhaem ao chefe da esquadra que bloqueava o porto do Recife, onde aquele pede ajuda em munição e armamento para que a Vila pudesse resistir aos revoltosos (Gazeta do Rio de Janeiro, $\mathrm{n}^{\circ} 40,17$ de maio de 1817). Na edição seguinte o redator do periódico afirma que ainda não se tinha verificado a notícia de achar-se Pernambuco "restituído à obediência devida, como geralmente se pensou", mas as tropas baianas já estavam de posse de toda a costa de Pernambuco desde 27 de abril (Gazeta do Rio de Janeiro, $\mathrm{n}^{\circ}$ 41, 21 de maio de 1817). Nessa edição, o redator da Gazeta ainda transcreve extratos d' A Idade d'Ouro do Brasil de 11 de abril a 2 de maio.

${ }^{28}$ Gazeta Extraordinária do Rio de Janeiro, $\mathrm{n}^{\circ} 3,16$ de junho de 1817.

${ }^{29}$ Gazeta do Rio de Janeiro, no 57,16 de julho de 1817.
} 
O desejo de apagar dos anais da história portuguesa os acontecimentos que tiveram lugar em Pernambuco em 1817, anunciado pelo redator da Gazeta do Rio de Janeiro, seria repetido por Varnhagen muitas décadas depois. Logo no início do capítulo da sua História Geral do Brasil dedicado aos acontecimentos pernambucanos (Seção LII), o Visconde de Porto Seguro afirma que aquele era um assunto "tão pouco simpático para o nosso ânimo que, se nos fora permitido passar sobre ele um véu, o deixaríamos de fora do quadro que nos propusemos traçar" ${ }^{30}$ Ainda assim, Maria Beatriz Nizza da Silva sintetiza a ideia da importância de se analisar a abordagem que a Gazeta faz do movimento:

Muito naturalmente ninguém vai estudar a Revolta de Pernambuco em 1817 por meio da Gazeta do Rio de Janeiro. Contudo, as tardias notícias publicadas sobre ela revelam o ponto de vista do governo e o modo como este pretendia orientar a opinião pública, o que também contribui para a reconstituição histórica do movimento. ${ }^{31}$

Concomitantemente, em Portugal era desarmada uma conspiração que tinha a intenção de derrubar a junta governativa do Reino, reorganizar a administração e o comércio, afastar o marechal Beresford e os oficiais ingleses e reformar o Exército. O Reino vivia uma profunda crise econômica e política advinda das consequências diretas e indiretas das guerras contra os franceses. ${ }^{32}$ Por trás da conspiração estava uma sociedade secreta denominada Supremo Conselho Regenerador de Portugal, Brasil e Algarves, constituída essencialmente por militares, com a participação de poucos letrados, e cujo grão-mestre era o general Gomes Freire de Andrade. Os membros, na maior parte, conheciam-se pessoalmente por terem servido juntos no Exército ou sob o comando de um mesmo oficial. Alguns tinham regressado da França poucos anos antes, onde haviam servido na Legião Portuguesa, criada por Junot. Depois de rápida investigação, foi ordenada a detenção dos suspeitos de integrarem a conspiração, a 24 de maio de 1817. Em 15 de outubro doze réus foram condenados à morte pelos

\footnotetext{
${ }^{30}$ VARNHAGEN, F. A. de. História Geral do Brasil: Antes da sua separação e independência de Portugal. Tomo V. p. 177.

${ }^{31}$ SILVA, M. B. N. da. A Gazeta do Rio de Janeiro (1808-1822): Cultura e Sociedade, p. 23.

32 Jorge Pedreira e Fernando Dores Costa citam a desorganização da produção agrícola e industrial, a desarticulação das comunicações e dos circuitos comerciais, o elevado custo de manutenção de um Exército numeroso, a presença de oficiais ingleses no comando das tropas portuguesas e, principalmente, os efeitos para a economia do Reino do fim do regime de exclusivo comercial. PEDREIRA e COSTA, p. 333/334.
} 
crimes de lesa-majestade de primeira cabeça e alta traição. Entre os quais Gomes Freire, apontado como líder da conspiração, apesar de Jorge Pedreira e Fernando Dores Costa afirmarem, que o seu papel na conspiração era, pelo contrário, muito limitado. ${ }^{33}$ Importante lembrar que Gomes Freire havia servido como comandante da Legião Portuguesa e havia sido acusado de colaborador dos franceses por ocasião da invasão do Reino em 1807. Ele pode ter enxergado na conspiração de 1817 mais uma oportunidade de pôr em prática um projeto político alternativo que voltasse a colocar Portugal no centro do Império. Ao contrário dos revolucionários pernambucanos, os conspiradores reinóis não pretendiam fundar uma República, e sim uma monarquia constitucional. ${ }^{34}$

Dessa forma, se, por um lado, esses movimentos revolucionários ocorridos em diferentes regiões do Império português denotavam a ausência de uma comunidade de interesses capaz de dar coesão ao ideal de Império veiculado pelo reformismo ilustrado português e posto em prática com a transferência da Corte; por outro lado, apontavam a inexistência, ainda em 1817, de vínculos políticos, econômicos ou culturais entre as diferentes regiões da América portuguesa que apontassem para um projeto de separação política entre a antiga colônia e a antiga metrópole. Ou seja, as tensões surgidas no interior do Império em 1815 e em 1817 parecem revelar, antes, os limites do projeto de construção do novo império português na América que, ao fim e ao cabo, podemos dizer que permaneceu apenas uma tentativa efêmera e com sérias dificuldades para se materializar de forma concreta.

A tese de que o processo de separação política entre metrópole e colônia tem como ponto de partida a transferência da Família Real Portuguesa para o Rio de Janeiro encontra um ponto de partida provável ainda no começo do século XIX na História dos principais sucessos políticos do Império do Brasil, escrita por José da Silva Lisboa, encarregado por D. Pedro I de escrever uma memória da independência e da Sua Aclamação como primeiro imperador do Brasil. ${ }^{35}$ E está

\footnotetext{
${ }^{33}$ Ibid., p. 341.

${ }^{34}$ Significativamente, não é publicada uma nota sequer sobre a conspiração na Gazeta do Rio de Janeiro, apesar de serem publicadas no periódico diversas notícias referentes a Portugal, algumas mesmo retiradas de periódicos portugueses, ao longo do segundo semestre de 1817.

${ }^{35}$ Herdeiro do reformismo ilustrado português e um dos principais construtores do novo império português, como espero que tenha ficado claro nesse trabalho, Silva Lisboa manteve-se fiel à monarquia como construtor do novo Império do Brasil, após a falência do projeto político ilustrado. Como explica Tereza Cristina Kirschner: "O livro expressa o imaginário político da elite
} 
firmemente consolidada na historiografia brasileira desde pelo menos a publicação da obra do diplomata e historiador Manuel de Oliveira Lima, D. João VI no Brasil, publicada por ocasião das comemorações do centenário da transferência da Corte portuguesa para a América, em 1908, promovidas pelo IHGB. ${ }^{36}$ A força dessa interpretação fez com que muitos autores analisassem o período joanino em função desse desfecho, adotando uma perspectiva que, por vezes, se torna excessivamente teleológica e nacionalista, e que enfatiza a dimensão de ruptura sobre a das continuidades entre o final do século XVIII em Portugal e as duas primeiras décadas do século XIX no Brasil.

Em outra perspectiva, porém, alguns autores enfatizaram os elementos de continuidade sobre os de ruptura. Como Kenneth Maxwell, por exemplo, que aponta no estabelecimento da Corte no Rio de Janeiro o fator decisivo para o abafamento das primeiras manifestações de insatisfação no final do século XVIII, próprias da crise do Antigo Regime, que poderiam levar à ruptura entre colônia e metrópole. ${ }^{37} \mathrm{Na}$ busca de superar o debate historiográfico sempre realizado $a$ posteriori, em direção à compreensão de como aqueles homens percebiam o momento histórico em que viviam, a partir da análise da produção da Impressão Régia do Rio de Janeiro, a dimensão de continuidade também se nos apresentou como hegemônica, apesar de não ser unânime. Dessa forma, sem a pretensão de negar a existência e importância do processo de interiorização da metrópole, é possível afirmar, todavia, que as duas primeiras décadas do século XIX guardariam uma relação muito mais próxima com os projetos de reforma do Império português, gestados ainda no século anterior, do que com a construção do Império do Brasil como corpo político autônomo. ${ }^{38}$

promotora da independência ao associar a transferência da corte portuguesa para o Brasil com o fim do período colonial e consagrar a ideia da inevitabilidade da independência em virtude da atitude "recolonizadora" das cortes portuguesas". KIRSCHNER, T. C. José da Silva Lisboa: Visconde de Cairú: itinerários de um ilustrado luso-brasileiro, p. 269/270.

${ }^{36} \mathrm{O}$ monarca português é considerado por aquele autor como o fundador da nacionalidade brasileira por ter propiciado as condições para a emancipação não somente material (com a abertura dos portos e a liberação das indústrias), mas também intelectual dos colonos (com a criação de instituições de ensino e da Impressão Régia). LIMA, O. D. João VI no Brasil, p. 21.

${ }^{37}$ MAXWELL, K. A geração de 1790 e a idéia do império luso-brasileiro, p. 157 a 207.

${ }^{38}$ Como deve ter ficado claro, meu pensamento a respeito do processo de ruptura entre Portugal e Brasil se afina com o pensamento de Lúcia Maria Bastos Pereira das Neves que, em Corcundas $e$ Constitucionais: a cultura política da Independência (1820-1822), ressalta como a ideia de separação política ganha força apenas no decorrer do ano de 1822, durante as discussões na Assembléia Constituinte Portuguesa: "Embora o discurso político, elaborado entre 1820 e 1822, tenha envolvido, majoritariamente, segmentos das elites brasileira e portuguesa, a partir de uma 
É importante não perder de vista, todavia, que por mais que a Impressão Régia, com seu trabalho de propaganda e censura, quisesse fazer parecer o contrário, não havia uma simples continuidade entre o projeto político gestado no ambiente ilustrado português e a sua execução em território diverso, a partir de 1808. Assim como não havia uma continuidade perfeita entre o passado, o presente e o futuro do Império português. Assim sendo, aquela continuidade era, assim como a herança sobre a qual se buscava construir o novo império português, antes de tudo uma construção discursiva. Que enfrentou oposições e gerou tensões que chegaram a ocupar o primeiro plano da cena política em momentos cruciais da consolidação (e de reforma) desse projeto, como em 1815 por ocasião da Elevação do Brasil a Reino Unido, e em 1817 às vésperas da Aclamação de D. João na América, como procurei chamar a atenção nessas considerações finais. Até que o acúmulo dessas tensões se materializasse no mais bem sucedido movimento de oposição àquele projeto político em 1820, e colocasse um ponto final às tentativas de construção de um poderoso império bihemisférico.

herança comum, o diálogo entre suas diversas facções não pôde ser aprofundado até que, demasiadamente avançado o processo, se colocasse em questão a integridade do império lusobrasileiro. (...) Até fins de 1821, havia um certo consenso entre elas [as elites políticas e culturais dos dois lados do Atlântico português] quanto à defesa da unidade do império luso-brasileiro e das ideias liberais. Mas, desvanecida a ilusão da integridade do Reino Unido, cada setor da elite buscou defender seus próprios interesses". NEVES, L. M. B. P. das. Corcundas e Constitucionais: a cultura política da Independência, p. 21. 


\section{6. REFERÊNCIAS BIBLIOGRÁFICAS}

\subsection{Fontes}

\subsubsection{Livros}

CÂMARA, Manuel Arruda da. Memória sobre a cultura dos algodoeiros e sobre o método de o escolher e ensacar. (1799) In: MELLO, J. A. G. de. Manuel Arruda da Câmara - Obras reunidas. Recife: Fundação de Cultura Cidade do Recife, 1982. p. 106 a 162.

Dissertação sobre as plantas do Brasil que podem dar linhos próprios para muitos usos da sociedade e suprir a falta do cânhamo.(1810) In: MELLO, J. A. G. de. Manuel Arruda da Câmara - Obras reunidas. Recife: Fundação de Cultura Cidade do Recife, 1982. p. 163 a 193.

Discurso sobre a utilidade da instituição de jardins nas principais províncias do Brasil. (1810) In: MELLO, J. A. G. de. Manuel Arruda da Câmara - Obras reunidas. Recife: Fundação de Cultura Cidade do Recife, 1982. p. 195 a 227.

COSTA, Hipólito José da. Descrição de uma máquina para tocar a bomba a bordo dos navios sem o trabalho de homens, oferecida a Real Marinha Portuguesa. Lisboa: Tipografia Calcográfica e literária do Arco do Cego, 1800.

Descrição da árvore açucareira, da sua utilidade e cultura, impressa de ordem superior. Lisboa: Tipografia Calcográfica e literária do Arco do Cego, 1800 .

Correio Braziliense ou Armazém Literário. São Paulo / Brasília: Imprensa Oficial do Estado / Correio Braziliense, 2001. $30 \mathrm{v}$.

COUTINHO, D. José Caetano da Silva. Memória Histórica da Invasão dos francezes em Portugal no ano de 1807. Rio de Janeiro: Na Impressão Régia, 1808.

FRANCO, Francisco Soares. Reflexões sobre a conduta do Príncipe Regente de Portugal. Rio de Janeiro: Na Impressão Régia, 1809.

GOMES, Bernardino Antonio. Memória sobre a canela do Rio de Janeiro, oferecida ao Príncipe do Brasil nosso senhor pelo Senado da Câmara da mesma cidade do ano de 1798. Rio de Janeiro: Na Impressão Régia, 1809.

GOMES, José Caetano. Memória sobre a cultura e produtos da cana de açúcar. Lisboa: Oficina Literária do Arco do Cego, 1800.

INSTRUÇÃO para os viajantes e empregados nas colônias sobre a maneira de colher, conservar e remeter os objetos de História Natural. Arranjada pela 
administração do Real Museu de História Natural de Paris. Traduzida por Ordem de Sua Majestade Fidelíssima, expedida pelo excelentíssimo Ministro e Secretario de Estado dos Negócios do Reino, do original francês impresso em 1818. Aumentada em notas de muitas das instruções aos correspondentes da Academia Real das Ciências de Lisboa, impressas em 1781; e precedida de algumas reflexões sobre a História Natural do Brasil e estabelecimento do Museu e Jardim Botânico em a Corte do Rio de Janeiro. Rio de Janeiro: Impressão Régia, 1819.

LISBOA, José da Silva. Carta Muito Interessante do advogado da Bahia, José da Silva Lisboa, para o doutor Domingos Vandelli, Diretor do Real Jardim Botânico de Lisboa, em que lhe dá notícia desenvolvida sobre a Bahia, descrevendo a cidade, as fortificações, a defesa militar, as tropas de guarnição, o comércio e a agricultura, e especialmente a cultura da cana-de-açúcar, tabaco, mandioca e algodão. Dá também as mais curiosas informações sobre a população, os usos e costumes, o luxo, a escravatura, a exportação, as construções navais, o comércio, a navegação para a Costa da Mina, etc. Bahia, 18 de outubro de 1781. Anais da Biblioteca Nacional. Rio de Janeiro: Oficinas gráficas da Biblioteca Nacional, 1910. v. 32. p. 494 a 506.

Princípios de Economia Política. Rio de Janeiro: Irmãos Pongetti Editores, 1956. (1 $1^{\text {a }}$ edição - 1804)

. Observações sobre o comércio franco do Brasil. Rio de Janeiro: Impressão Régia, 1808/1809.

Observações sobre a franqueza da indústria e estabelecimento de fábricas no Brasil. Rio de Janeiro: Impressão Régia, 1810.

Observações sobre a prosperidade do Estado pelos liberais princípios da nova legislação do Brasil. Rio de Janeiro: Na Impressão Régia, 1810.

Memória dos benefícios políticos do governo d'el Rei D. João VI. Rio de Janeiro: Arquivo Nacional, 1940. Edição Fac-Similar. (1ª edição - 1818)

Estudos do Bem Comum e Economia Política, ou ciência das leis naturais e civis de animar e dirigir a geral indústria e promover a riqueza nacional e prosperidade do Estado. Rio de Janeiro: Impressão Régia, 18191820 .

NEVES, José Accúrsio. A Salvação da Pátria. Proclamação aos portugueses sobre a sua honra e o seu dever nas atuais circunstâncias da monarquia. Rio de Janeiro: Impressão Régia, 1809.

O Despertador dos Soberanos e dos Povos. Rio de Janeiro: Na Impressão Régia, 1809.

Manifesto da razão contra as usurpações francesas. Rio de Janeiro: Impressão Régia, 1809.

Reflexões sobre a invasão dos franceses em Portugal. Rio de Janeiro: Impressão Régia, 1809. 
História Geral da dos Franceses em Portugal e da Restauração deste Reino. Lisboa: Impressão Régia, 1810-1812. 5v.

Variedades sobre objetos relativos às artes, comércio e manufaturas, consideradas segundo os princípios da Economia Política. 2 v. Lisboa: Impressão Régia, 1814-1817.

Memória sobre os meios de melhorar a indústria portuguesa, considerada nos seus diferentes ramos. Lisboa: Impressão Régia, 1820.

Noções, históricas, econômicas e administrativas sobre a produção e manufatura das sedas em Portugal, e particularmente sobre a Real Fábrica do Subúrbio do Rato e suas anexas. Lisboa: Na Impressão Régia, 1827.

PROTEÇÃO à Francesa. Rio de Janeiro: na Impressão Régia, 1809.

SANTOS, Luiz Gonçalves dos. Memórias para servir à História do Reino do Brasil. Belo Horizonte / São Paulo: Itatiaia / EdUSP, 1981. 2v.

SILVA, Antonio Carlos Ribeiro de Andrade Machado e. Considerações cândidas e imparciais sobre a natureza do comércio do açúcar, trasladadas do inglês. Lisboa: Na Oficina da Casa Literária do Arco do Cego, 1800.

SILVA, Antonio de Moraes. Dicionário da Língua Portuguesa. Lisboa: Typographia Lacerdina, 1813. $2^{a}$ edição.

STOCKLER, Francisco e Borja Garção. Cartas ao autor da História Geral da invasão dos franceses em Portugal e da restauração deste reino. Rio de Janeiro: Na Impressão Régia, 1813.

VANDELLI, D. Breves Instruções aos correspondentes da Academia de Ciências de Lisboa, sobre as remessas dos produtos e notícias pertencentes à História da Natureza para formar um Museu Nacional. Lisboa: Oficina Typografica, 1781.

VELOSO, José Mariano da Conceição. O Fazendeiro do Brasil, melhorado na economia rural dos gêneros já cultivados e de outros que se podem introduzir, nas fábricas que lhe são próprias, segundo o melhor que se tem escrito a este assunto. Lisboa: Na Régia Officina Typográfica, 1798-1806. 5 tomos.

Naturalista instruído nos diversos métodos antigos e modernos de ajuntar, preparar e conservar as produções dos três reinos da natureza, coligido de diferentes autores, dividido em vários livros. Lisboa: $\mathrm{Na}$ Oficina da Casa Literária do Arco do Cego, 1800.

Extrato sobre os engenhos de açúcar do Brasil e sobre o método já então praticado na fatura deste sal essencial, tirado da obra Riqueza e Opulência do Brasil. Lisboa: Na Tipografia Calcográfica e Literária do Arco do Cego, 1800. 


\subsubsection{Periódicos}

BARROS, Domingos Borges de. Notícia acerca dos vários carros de transporte, e particularmente dos que os franceses chamam Haquet, invenção do célebre Pascal. O Patriota: Jornal literário, político e mercantil. Rio de Janeiro: Na Impressão Régia, nº 4, p. 68-81, abr. 1813.

Memória sobre o café, sua história, cultura e amanhos. O Patriota: Jornal literário, político e mercantil. Rio de Janeiro: Na Impressão Régia. $\mathrm{n}^{\circ}$, p. 3-15, mai. 1813 ; no 6, p. 31-43, jun. 1813; no 2, p. 3-12, ago. 1813.

Notícia sobre o meio que se seguiu no esgotamento de um pântano. $\mathbf{O}$

Patriota: Jornal literário, político e mercantil. Rio de Janeiro: Na Impressão Régia. no 6, p. 3-5, dez. 1813.

Correio Braziliense ou Armazém Literário. Londres. Impresso por W. Lewis, Paternoster-Row. 1808-1821.

Gazeta do Rio de Janeiro. Rio de Janeiro: Impressão Régia do Rio de Janeiro. $1808-1821$.

Gazeta Extraordinária do Rio de Janeiro. Rio de Janeiro: Impressão Régia do Rio de Janeiro. 1808-1821

guimarães, Manuel Ferreira de Araújo. Prospecto (do Patriota). Rio de Janeiro: Impressão Régia, 1812.

Advertência. O Patriota: Jornal literário, político e mercantil. Rio de Janeiro: Impressão Régia. nº 6, p. 83, dez. 1813.

Exame da resposta defensiva e analítica à censura que o redator do Patriota fez ao drama intitulado O Juramento dos Numes. O Patriota: Jornal literário, político e mercantil. Rio de Janeiro: Impressão Régia. $n^{\circ}$ 1, p. 63-92, jan./fev. 1814.

GUSMÃO, Alexandre de. Cálculo sobre a perda do dinheiro do Reino. O Patriota: Jornal literário, político e mercantil. Rio de Janeiro: Impressão Régia. $\mathrm{n}^{\mathrm{o}}$ 1, p. 101-107, jan./fev. 1813.

MACEDO, Duarte Ribeiro de. Discurso do doutor Duarte Ribeiro de Macedo sobre a introdução das artes no Reino, que escreveu sendo enviado na corte de Paris no ano de 1675. O Patriota: Jornal literário, político e mercantil. Rio de Janeiro: Impressão Régia. no 2, p. 41-50, ago. 1813; nº 3, p. 34-49, set. 1813; nº 4, p. 29-47, out. 1813.

OBRAS publicadas nesta Corte no mês de Outubro. O Patriota Jornal literário, político e mercantil. Rio de Janeiro: Impressão Régia. nº 4, p. 92-93, out. 1813.

QUINTÃO, Jacinto José da Silva. Memória sobre a cochonilha e o método de a propagar, oferecida aos lavradores brasileiros por um patriota zeloso e amante da felicidade pública. O Patriota Jornal literário, político e mercantil. Rio de Janeiro: Na Impressão Régia. nº 4, p. 11-19, out. 1813. 


\subsection{Livros e artigos}

ALGRANTI, Leila Mezan. Censura e comércio de livros no período de permanência da corte portuguesa no Rio de Janeiro (1808-18221). Revista Portuguesa de História. Coimbra: Faculdade de Letras da Universidade de Coimbra, Tomo XXXIII, vol. II, p. 631-663, 1999.

Livros de Devoção, Atos de censura: cultura religiosa na América portuguesa. São Paulo: HUCITEC/ FAPESP, 2004.

Os bastidores da censura na corte de D. João: as disputas por honra e prestígio no exercício do poder. In: ANAIS do Seminário Internacional D. João VI, um rei aclamado na América. Rio de Janeiro: Museu Histórico Nacional, 2000. p. 82 a 93.

ALMODOVAR, Antônio. Texto e contexto: a questão dos privilégios de novo invento em José Acúrsio das Neves. In: ALMODOVAR, Antônio; CASTRO Armando de (org.). Obras completas de José Accursio das Neves. Porto: Afrontamento, 1984-1985. v. 4.

ALVES, Rafael Rodrigues Dias. Os estudantes naturais do Brasil e a Universidade de Coimbra após a reforma dos estatutos universitários de 1772. Niterói, 2006. Dissertação (Mestrado em História Social) - Instituto de Ciência Humanas e Filosofia, Universidade Federal Fluminense.

ARAÚJO, Valdei Lopes de. O tempo como repetição. In: A experiência do tempo: modernidade e historicização no Império do Brasil (1813-1845). São Paulo: Hucitec, 2008. p. 25 a 55.

ARENDT, Hannah. Entre o passado e o futuro. São Paulo: Perspectiva, 1992. $3^{\text {a }}$ edição.

BARRA, Sérgio Hamilton da Silva. Entre a Corte e a Cidade: O Rio de Janeiro no Tempo do Rei (1808-1821). Rio de Janeiro: José Olympio, 2008.

BARROS, Mariana Monteiro de; MOREL, Marco. O raiar da imprensa no horizonte do Brasil. In: Palavra, Imagem e Poder: O surgimento da Imprensa no Brasil do século XIX. Rio de Janeiro: DP\&A, 2003. p. 11-50.

BOXER, Charles Ralph. O Império Marítimo Português (1415-1825). São Paulo: Companhia das Letras, 2002.

BRIGOLA, João Carlos. Museologia e História Natural em finais de setecentos o caso do Real Museu e Jardim Botânico da Ajuda (1777-1808). Actas do Colóquio "A Casa Literária do Arco do Cego". Anais Série História. Vol. VII/VIII. Lisboa: Universidade Autónoma de Lisboa, 2001. p. 219 a 244.

CABRAL, Alfredo do Valle. Annaes da Imprensa Nacional do Rio de Janeiro de 1808 a 1822. Rio de Janeiro: Typographia Nacional, 1881. 
CALDEIRA, Jorge. José Bonifácio de Andrada e Silva. São Paulo: Editora 34, 2002.

CAMARGO, Ana Maria de Almeida; MORAES, Rubens Borba de. Bibliografia da Impressão Régia do Rio de Janeiro. São Paulo: EdUSP/Kosmos, 1993. 2 v.

CAMPOS, Fernando. José Accursio das Neves: O historiador, o economista, o panfletário. Lisboa: Edições Gama, 1946.

CÂNDIDO, Antônio. Formação da literatura brasileira: momentos decisivos. São Paulo: Martins, 1959. 2v.

CARDOSO, José Luís. O pensamento econômico em Portugal nos finais do século XVIII. 1780-1808. Lisboa: Estampa, 1989.

O Pensamento econômico na época da Restauração. Penélope: fazer e desfazer a história. Lisboa. nº 9/10, p. 135-149, fev. 1993.

D. Rodrigo de Souza Coutinho, a Casa Literária do Arco do Cego e a difusão técnica e científica em Portugal. Actas do Colóquio "A Casa Literária do Arco do Cego". Anais Série História. Vol. VII/VIII. Lisboa: Universidade Autónoma de Lisboa, 2001. p. 193 a 201.

CARDOSO, Teresa Maria Fachada Levy. A Gazeta do Rio de Janeiro: subsídios para a história da cidade (1808-1821). Revista do Instituto Histórico e Geográfico Brasileiro. Rio de Janeiro. Ano 152. n ${ }^{\circ} 371$, p. 341-436, abr./jun. 1991.

CARTAS de Luiz Joaquim dos Santos Marrocos, escritas do Rio de Janeiro à sua família em Lisboa, de 1811 a 1821. Anais da Biblioteca Nacional. Serviço Gráfico do Ministério da Educação: Rio de Janeiro, 1934. volume LVI.

CARVAlHO, Flávio Rey de. Um Iluminismo Português? A Reforma da Universidade de Coimbra (1772). São Paulo: Annablume, 2008.

CARVALHO, Marieta Pinheiro de. Uma ideia ilustrada de cidade: as transformações urbanas no Rio de Janeiro de D. João VI (1808-1821). Rio de Janeiro: Odisseia, 2008.

CASTRO, Renato Berbert de. A primeira imprensa da Bahia e suas publicações. Salvador: Imprensa Oficial da Bahia, 1969.

CATROGA, Fernando. Os passos do homem como restolho do tempo: memória e fim do fim da história. Coimbra: Almedina, 2009.

CAVALCANTE, Berenice. Os letrados da sociedade colonial: as academias e a cultura do Iluminismo no final do século XVIII. Revista Acervo. Rio de Janeiro: Arquivo Nacional, vol. 8, nº1-2, p. 53-66, jan./dez. 1995.

CHARTIER, Roger. A História Cultural: entre práticas e representações. Rio de Janeiro: Bertrand Brasil, 1990. 
COSTA, Wilma P.; OLIVEIRA, Cecília Helena Salles (org.). De um império a outro: formação do Brasil, séculos XVIII e XIX. São Paulo: Hucitec, 2007.

CURTO, Diogo Ramada. D. Rodrigo de Souza Coutinho e a Casa Literária do Arco do Cego. In: CAMPOS, Fernanda Maria Guedes de (org.). A Casa Literária do Arco do Cego (1799-1801): bicentenário "sem livros não há instrução". Lisboa: Biblioteca Nacional / Imprensa Nacional / Casa da Moeda, 1999. p. 15 a 49.

Campinas: Editora Unicamp, 2009.

DIAS, Maria Odila da Silva. Aspectos da Ilustração no Brasil. Revista do Instituto Histórico e Geográfico Brasileiro. Vol. 278, p. 105 a 170, jan./mar. 1968.

A interiorização da metrópole (1808-1853). In: MOTA, Carlos Guilherme. 1822: Dimensões. São Paulo: Perspectiva, 1972. p. 160 a 184.

ELIAS, Norbert. O Processo Civilizador. Rio de Janeiro: Zahar, 1993. v 1.

FALCON, Francisco José Calazans. Da Ilustração à Revolução - percursos ao longo do espaço-tempo setecentista. Revista Acervo. Rio de Janeiro: Arquivo Nacional. vol. 4, nº 1, p. 53 a 87, Jan./jul. 1989.

A Época Pombalina: Política Econômica e Monarquia Ilustrada. São Paulo: Editora Ática, 1993.

FARIA, Miguel Figueira de. Casa Literária do Arco do Cego exemplo singular na História da edição ilustrada em Portugal. Apontamentos para uma biografia. Actas do Colóquio "A Casa Literária do Arco do Cego". Anais Série História. Vol. VII/VIII. Lisboa: Universidade Autónoma de Lisboa, 2001. p. 21 a 50.

FILGUEIRAS, Carlos A. L.; MARQUES, Adílio Jorge. O Químico e Naturalista luso-brasileiro Alexandre Antonio Vandelli. Química Nova. São Paulo: Sociedade Brasileira de Química. vol. 32, nº 9, p. 2492-2500, 2009.

FONSECA, Maria Rachel Fróes da. Luzes das Ciências na Corte Americana: Observações sobre o periódico "O Patriota". Anais do Museu Histórico Nacional. Rio de Janeiro: Ministério da Cultura / IPHAN. vol. 31, p. 81 a 104, 1999.

O associativismo científico no Brasil (1771-1829) e a promoção das ciências e da felicidade da nação. In: ANAIS do Seminário Internacional D. João VI, um rei aclamado na América. Rio de Janeiro: Museu Histórico Nacional, 2000. p. 123 a 139.

GODINHO, Vitorino Magalhães. A Estrutura na Antiga Sociedade Portuguesa. Lisboa: Arcádia, 1971. 
GUERRA, François-Xavier. A nação na América espanhola: a questão das origens. Revista Maracanan. Rio de Janeiro: UERJ-IFCH. Ano 1, número 1, p. 9 a $30,1999 / 2000$.

GUIMARÃES, Manuel Luiz Salgado. De Paris ao Rio de Janeiro: a institucionalização da escrita da história. Revista Acervo. Rio de Janeiro: Arquivo Nacional. vol. 4, nº 1, p. 135 a 143, Jan./jul. 1989.

HALLEWELL, Laurence. A Paulo Martin e a Impressão Régia. In: O Livro no Brasil. São Paulo: EdUSP, 1985. p. 25 a 50.

HARTOG, François. Tempo, História e a Escrita da História: A Ordem do Tempo. Revista de História. São Paulo. nº 148, p. 9 a 34, jul. 2003.

HOLANDA, Sérgio Buarque de. A Herança colonial - sua desagregação. In: (org.). O Brasil Monárquico: O Processo de Emancipação. Rio de Janeiro: Editora Bertrand Brasil, Tomo II, vol 3, p. 13 a 47. 2003. 9a edição. (História Geral da Civilização Brasileira)

Inatualidade de Cairu. In:

Para uma nova história. São Paulo:

Fundação Perseu Abramo, 2004. p. 83 a 87.

IPANEMA, Cybele de. A imprensa no tempo de D. João. In: ANAIS do Seminário Internacional D. João VI, um rei aclamado na América. Rio de Janeiro: Museu Histórico Nacional, 2000. p. 235 a 245.

KANTOR, Íris. Mapas em trânsito: projeções cartográficas e processo de emancipação política do Brasil (1779-1822). Araucaria - Revista Iberoamericana de Filosofía, Política y Humanidades. Año 12, nº 24, p. 110 a 123, segundo semestre de 2010.

KIRSCHNER, Tereza Cristina. José da Silva Lisboa, Visconde de Cairú: itinerários de um ilustrado luso-brasileiro. São Paulo / Belo Horizonte: Alameda / PUC Minas, 2009.

KOSELLECK, Reinhart. Historia Magistra Vitae - sobre a dissolução do topos na história moderna em movimento. In: Futuro Passado: contribuição à semântica dos tempos históricos. Rio de Janeiro: Contraponto / Editora PUCRio, 2006. p. 41 a 60.

.Espaço de experiência" e "horizonte de expectativas": duas categorias históricas. In: Futuro Passado: contribuição à semântica dos tempos históricos. Rio de Janeiro: Contraponto / Editora PUC-Rio, 2006. p. 305 a 327.

KURY, Lorelai (org.). Iluminismo e Império no Brasil: O Patriota (1813-1814). Rio de Janeiro: Editora Fiocruz, 2008.

KURY, Lorelai Brilhante; MUNTEAL FILHO, Oswaldo. Cultura científica e sociabilidade intelectual no Brasil setecentista: um estudo acerca da Sociedade Literária do Rio de Janeiro. Revista Acervo. Rio de Janeiro: Arquivo Nacional, vol. 8, nº1-2, p. 105 a 122, jan./dez. 1995. 
LIGHT, Kenneth. A viagem marítima da Família Real: A transferência da corte portuguesa para o Brasil. Rio de Janeiro: Jorge Zahar Ed., 2008.

LIMA, Oliveira. D. João VI no Brasil. Rio de Janeiro: Topbooks, 1996. $3^{\text {a }}$ ed.

LOUREIRO, Fernando Pinto. José Acúrsio das Neves: precursor do industrialismo em Portugal. Coimbra: Coimbra Editora Ltda, 1954.

LUSTOSA, Isabel. A Pátria de Hipólito. In: COSTA, Hipólito José da. Correio Braziliense ou Armazém Literário. São Paulo / Brasília: Imprensa Oficial do Estado / Correio Braziliense, 2001. v. 1. p. xxxix a liv.

LYRA, Maria de Lourdes Viana. A Utopia do poderoso império. Rio de Janeiro: Sette Letras, 1994.

MACHADO, Humberto Fernandes; NEVES, Lucia Maria Bastos Pereira das. O Império do Brasil. Rio de Janeiro: Nova Fronteira, 1999.

MAGALHÃES, José Calvet. José Acúrsio das Neves. Lisboa: SNI, 1946.

MALERBA, Jurandir. A corte do exílio: civilização e poder no Brasil às vésperas da Independência (1808-1821). São Paulo: Companhia das Letras, 2000.

MATTOS, Ilmar Rohloff de. O Tempo Saquarema: a formação do Estado imperial. São Paulo: Hucitec, 2004. $5^{\text {a }}$ edição.

O Rio de Janeiro e a Experiência Imperial. In: AZEVEDO, André Nunes (org.). Rio de Janeiro: Capital e Capitalidade. Rio de Janeiro: Departamento Cultural/NAPE/DEPEXT/SR-3-UERJ, 2002. p.77-86.

. Do Império do Brasil ao Império do Brasil. in: FACULDADE DE LETRAS da UNIVERSIDADE do PORTO (org.). Estudos em homenagem a Luis Antonio de Oliveira Ramos. Porto: Universidade do Porto, 2004. v.2. p. 727-736.

Construtores e Herdeiros: a trama dos interesses na construção da unidade política. Almanack Brasiliense. São Paulo: USP. nº 1, p. 8 a 26, Maio de 2005 .

Transmigrar - nove notas a propósito do Império do Brasil. In: PAMPLONA, Marco A. \& STUVEN, Ana Maria (org.). Estado e Nação no Brasil e no Chile ao longo do século XIX. Rio de Janeiro: Garamond, . p. 97 a 124.

MAXWELL, Kenneth. A Devassa da devassa: a Inconfidência Mineira, Brasil Portugal 1750-1808. Rio de Janeiro: Paz e Terra, 1978.

Condicionalismos da independência do Brasil. in: SERRÃO, Joel; MARQUES, Oliveira (dir.). Nova História da Expansão Portuguesa. O Império Luso-Brasileiro (1750-1822). Lisboa: Estampa, 1986. v. VIII. 
Terra, 1996.

Marquês de Pombal: O Paradoxo do Iluminismo. Rio de Janeiro: Paz e A geração de 1790 e a idéia do império luso-brasleiro. In: Chocolates, piratas e outros malandros: ensaios tropicais. Rio de Janeiro: Paz e Terra, 1999. p. 157 a 207.

MEIRELLES, Juliana Gesuelli. Imprensa e poder na corte joanina: A Gazeta do Rio de Janeiro (1808-1821). Rio de Janeiro: Arquivo Nacional, 2008.

MELLO, Evaldo Cabral de. A outra Independência: o Federalismo Pernambucano de 1817 a 1824. São Paulo: Editora 34, 2004.

MELLO, José Antônio Gonsalves de. Manuel Arruda da Câmara: obras reunidas c. 1752-1811. Recife: Fundação de Cultura Cidade do Recife, 1982.

MONTEIRO, Pedro Meira. Um moralista nos trópicos: o Visconde de Cairu e o Duque de La Rochefoulcauld. Rio de Janeiro: Boitempo /FAPESP, 2004.

MONTEIRO, Rodrigo Bentes. Folhetos em ordem na coleção Barbosa Machado. In: ALGRANTI, Leila Mezan; MEGIANI, Ana Paula. O Império por escrito. São Paulo: Alameda, 2009. p. 201 a 228.

MORAES, Rubens Borba de. Livros e Bibliotecas no Brasil Colonial. São Paulo: Secretaria de Cultura, Ciência e Tecnologia, 1979.

MOTA, Carlos Guilherme. Nordeste 1817: Estruturas e Argumentos. São Paulo: Perspectiva / EdUSP, 1972.

MUNTEAL FILHO, Oswaldo. Domenico Vandeli no Anfiteatro da Natureza: A Cultura Científica do Reformismo Ilustrado Português na Crise do Antigo Sistema Colonial (1779-1808). Rio de Janeiro, 1993. Dissertação (Mestrado em História) - Departamento de História, Pontifícia Universidade Católica do Rio de Janeiro.

O Príncipe D. João e o Mundo de Queluz: Despotismo ministerial, tensões estamentais e sacralização do Estado na crise do Antigo Regime português. Anais do Museu Histórico Nacional. Rio de Janeiro: Ministério da Cultura / IPHAN. vol. 31, p. 9 a 34, 1999.

O Rei e o Naturalista. In: ANAIS do Seminário Internacional D. João VI, um rei aclamado na América. Rio de Janeiro: Museu Histórico Nacional, 2000. p. 140 a 160.

NEPOMUCENO, Rosa. Jardim das Especiarias: pólvora e cravos, primeiros plantios, conquistas, aventuras e lendas. In: O Jardim de D. João. Rio de Janeiro: Casa da Palavra, 2008. p. 14 a 33.

NEVES, Lucia Maria Bastos P. das. Comércio de Livros e censura de idéias: a atividade dos livreiros franceses no Brasil e a vigilância da Mesa do Desembargo do Paço (1795-1822). Ler História. Lisboa: Portugal. Nº 23, p. 61-78, 1993. 
Da Repulsa ao Triunfo - ideias francesas no Império Luso-Brasileiro, 1808-1815. Anais do Museu Histórico Nacional. Rio de Janeiro: Ministério da Cultura / IPHAN. vol. 31, p. 35 a 54, 1999.

Pensamentos vagos sobre o Império do Brasil. In: LUSTOSA, Isabel et al. Hipólito José da Costa e o Correio Braziliense. São Paulo / Brasília: Imprensa Oficial do Estado / Correio Braziliense, 2002. v. 30. tomo 1. p. 469 a 513.

Um silêncio perverso: censura, repressão e o esboço de uma primeira esfera pública de poder (1820-1823). In: CARNEIRO, Maria Luiza Tucci (org.). Memórias Silenciadas: História da censura no Brasil. São Paulo: EdUSP/FAPESP, 2002. p. 121 a 153.

Corcundas e Constitucionais: a cultura política da Independência (1820-1822). Rio de Janeiro: Revan/Faperj, 2003.

Napoleão Bonaparte: Imaginário e Política em Portugal c. 1808-1810. Alameda Casa Editorial, 2008.

Estado e Política na Independência. In: GRINBERG, Keila \& SALLES, Ricardo. O Brasil Imperial, vol 1: 1808-1831. Rio de Janeiro: Civilização Brasileira, 2009. p. 95 a 136.

NEVES, Lucia Maria Bastos P.; FERREIRA, Tânia Maria Bessone. O medo dos abomináveis princípios franceses: a censura dos livros nos inícios do século XIX no Brasil. Revista Acervo. Rio de Janeiro: Arquivo Nacional. vol. 4, n 1, p. 113 a 119, Jan./jul. 1989.

NEVES, Lucia Maria Bastos P.; VAINFAS, Ronaldo. Dicionário do Brasil Joanino - 1808-1821. Rio de Janeiro: Objetiva, 2008.

NORTON, Luís. A Corte de Portugal no Brasil: Notas, documentos diplomáticos e cartas da imperatriz Leopoldina. Lisboa: Empresa Nacional de Publicidade. 1968. $2^{\mathrm{a}}$ edição.

NOVAIS, Fernando A. Portugal e Brasil na crise do Antigo Sistema Colonial (1777-1808). $4^{\text {a }}$ ed. São Paulo: Hucitec, 1986.

A Proibição de manufaturas no Brasil e a política econômica portuguesa do fim do século XVIII. Revista de História. São Paulo: USP, nº 142-143, p. 213 a 237,2000 .

NOVAIS, Fernando A.; ARRUDA, José Jobson de Andrade. Prometeus e Atlantes na forja da nação. Economia e Sociedade. Campinas: UNICAMP, $n^{\circ} 2$ (21), v. 12, p. 225 a 243, jul/dez 2003.

OLIVEIRA, Cecília Helena de Salles. Repercussões da revolução: delineamento do império do Brasil, 1808/1831. In: GRINBERG, Keila \& SALLES, Ricardo. O Brasil Imperial, vol 1: 1808-1831. Rio de Janeiro: Civilização Brasileira, 2009. p. 15 a 54. 
OLIVEIRA, José Carlos de. A Cultura científica e a Gazeta do Rio de Janeiro (1808-1821). Revista da Sociedade Brasileira de História da Ciência. Rio de Janeiro: MAST, n ${ }^{\circ}$ 17, p. 29 a 58, 1997.

D. João VI e a cultura científica. Rio de Janeiro: EMC, 2008.

PEDREIRA, Jorge; COSTA, Fernando Dores. D. João VI: um príncipe entre dois continentes. São Paulo: Companhia das Letras, 2008.

PIMENTA, João Paulo Garrido. Portugueses, americanos, brasileiros: identidades políticas na crise do Antigo Regime luso-americano. Almanack Braziliense. $n^{\circ} 3$, p. 69-80, maio de 2006.

POLLAK, Michael. Memória, Esquecimento, Silêncio. Estudos Históricos. Rio de Janeiro: Cpdoc/Fundação Getúlio Vargas. v.2, no 3, p. 3-15, 1989.

Memória e Identidade Social. Estudos Históricos. Rio de Janeiro:

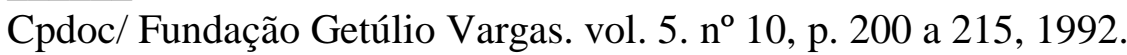

RIZZINI, Carlos. Hipólito José da Costa e o Correio Braziliense. São Paulo: Cia. Editora Nacional, 1957.

O livro, o jornal e a tipografia no Brasil, 1500-1822: um breve estudo geral sobre a informação. São Paulo: Imprensa Oficial do Estado, 1988.

ROCHA, Antônio Penalves. A Economia Política na Sociedade Escravista: Um estudo dos textos econômicos de Cairu. São Paulo: Hucitec, 1996.

ROCHA, Antônio Penalves (org.). José da Silva Lisboa: Visconde de Cairú. São Paulo: Editora 34, 2001.

RODRIGUES, Graça Almeida. Breve História da Censura Literária em Portugal. Lisboa: Instituto de Cultura e Língua Portuguesa / Ministério da Educação e Ciência, 1980. Biblioteca Breve. v. 54.

ROSSI, Paulo. Ricordare e Dimenticare. In: Il passato, la memoria, l'oblio: Otto saggi di storia delle idee. Bologna: Il Mulino, 1991. p. 13-34.

Unesp, 2000.

SAID, Edward W. Cultura e Imperialismo. São Paulo: Companhia das Letras, 1999.

SANTOS, Afonso Carlos Marques dos. No Rascunho da Nação: Inconfidência no Rio de Janeiro. Rio de Janeiro: Secretaria Municipal de Cultura, Turismo e Esportes, 1992.

SANTOS, Nívia Pombo Cirne dos. Dom Rodrigo de Sousa Coutinho: Pensamento e ação político-administrativa no Império português (1778-1812). Niterói, 2002. Dissertação (Mestrado em História Social) - Instituto de Ciências Humanas e Filosofia, Universidade Federal Fluminense. 
SCHIAVINATTO, Iara Lis. Entre histórias e historiografias: algumas tramas do governo joanino. In: GRINBERG, Keila; SALLES, Ricardo. O Brasil Imperial, vol 1: 1808-1831. Rio de Janeiro: Civilização Brasileira, 2009. p. 55 a 93.

SCHULTZ, Kirsten. Versalhes Tropical: Império, monarquia e corte real portuguesa no Rio de Janeiro, 1808-1821. Rio de Janeiro: Civilização Brasileira, 2008 .

SCHWARCZ, Lilia Moritz. A Longa Viagem da Biblioteca dos Reis: do terremoto de Lisboa à Independência do Brasil. São Paulo: Companhia das Letras, 2002 .

SILVA, Ana Cristina Fonseca Nogueira da. Nação federal ou nação bihemisférica? O Reino Unido de Portugal, Brasil e Algarves e o "modelo" colonial português do século XIX. Almanak Brasiliense. São Paulo: USP. nº 9, p. 68 a 83, Maio de 2009.

SILVA, Ana Rosa Cloclet. Inventando a nação: intelectuais ilustrados e estadistas luso-brasileiros na crise do Antigo Regime português 1750-1822. São Paulo: Hucitec, 2006.

SILVA, Antonio de Moraes e. Diccionario da Lingua Portugueza. Lisboa: Tipografia de M.P. de Lacerda, 1813. 2 v.

SILVA, Maria Beatriz Nizza da. Cultura e Sociedade no Rio de Janeiro (18081821). $2^{a}$ ed. São Paulo, Editora Nacional, 1978.

Cultrix, 1978.

A Primeira Gazeta da Bahia: Idade d'Ouro do Brasil. São Paulo:

Vida Privada e quotidiana no Brasil na época de D. Maria I e D. João VI. Lisboa: Estampa, 1993.

O botânico Fr. José Mariano da Conceição Veloso e sua expedição na capitania do Rio de Janeiro. Actas do Colóquio "A Casa Literária do Arco do Cego". Anais Série História. Vol. VII/VIII. Lisboa: Universidade Autónoma de Lisboa, 2001. p. 203 a 218.

A Idade d'Ouro do Brasil e as formas de sociabilidade baianas. In: NEVES, Lucia Maria Bastos; MOREL, Marco; FERREIRA, Tania Maria Bessone. História e Imprensa: representações culturais e práticas de poder. Rio de Janeiro: DP\&A / Faperj, 2006. p. 155 a 175.

A Gazeta do Rio de Janeiro (1808-1822): Cultura e Sociedade. Rio de Janeiro: EdUERJ, 2007.

PAULA, Sérgio Goes de (organização e introdução). Hipólito José da Costa. São Paulo: Editora 34, 2001.

SODRÉ, Nélson Werneck. A Imprensa Colonial. In: História da Imprensa no Brasil. Rio de Janeiro: Civilização Brasileira, 1966. p. 11 a 49. 
SOUZA, Iara Lis Carvalho. Pátria Coroada: o Brasil como corpo político autônomo, 1780-1831. São Paulo: UNESP, 1999.

SOUZA, Simone Cristina Mendonça de. Primeiras Impressões: romances publicados pela Impressão Régia do Rio de Janeiro (1808-1822). Campinas, 2007. Tese (Doutorado em Teoria e História Literária) - Instituto de Estudos da Linguagem, Universidade Estadual de Campinas.

TAVARES, Rui. Lembrar, esquecer, censurar. Estudos Avançados. São Paulo: Instituto de Estudos Avançados da USP. vol. 13, no 37, p. 125 a 154, Set./dez. 1999.

TELLES, Ângela Cunha da Motta. A Marcha Civilizadora nos trópicos. Anais do Museu Histórico Nacional. Rio de Janeiro: Ministério da Cultura / IPHAN. vol. 31, p. 55 a $68,1999$.

VARNHAGEN, Francisco Adolfo de. História Geral do Brasil: Antes da sua separação e independência de Portugal. São Paulo: Melhoramentos, Tomo V, $3^{\mathrm{a}}$ ed., 1907.

VILLALTA, Luiz Carlos. Reformismo ilustrado, censura e práticas de leitura: usos do livro na América Portuguesa. São Paulo: EdUSP, 1999.

Censura literária e inventividade dos leitores no Brasil colonial. In: CARNEIRO, Maria Luiza Tucci (org.). Memórias Silenciadas: História da censura no Brasil. São Paulo: EdUSP/FAPESP, 2002. p. 45 a 89.

. Libertinagens e livros libertinos no mundo luso-brasileiro (1740-1802). In: ALGRANTI, Leila Mezan; MEGIANI, Ana Paula. O Império por escrito. São Paulo: Alameda, 2009. p. 523 a 563.

WEGNER, Robert. Livros do Arco do Cego no Brasil colonial. História, Ciências, Saúde. Rio de Janeiro: Fundação Oswaldo Cruz. vol. 11, suplemento 1, p. 131 a 140, 2004.

WEHLING, Arno; WEHLING, Maria José C. de. Formação do Brasil Colonial. Rio de Janeiro: Nova Fronteira, 1994. 